\title{
Managing Hull-Borne Invasive Species and Coastal Water Quality for California and Baja California Boats Kept in Saltwater
}

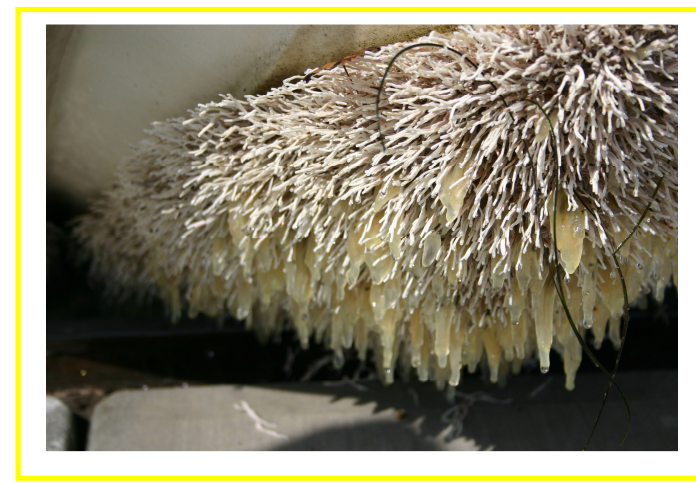

\author{
Tubeworms (Hydroides sp.) \\ and Sea Squirts (Ciona sp.)
}

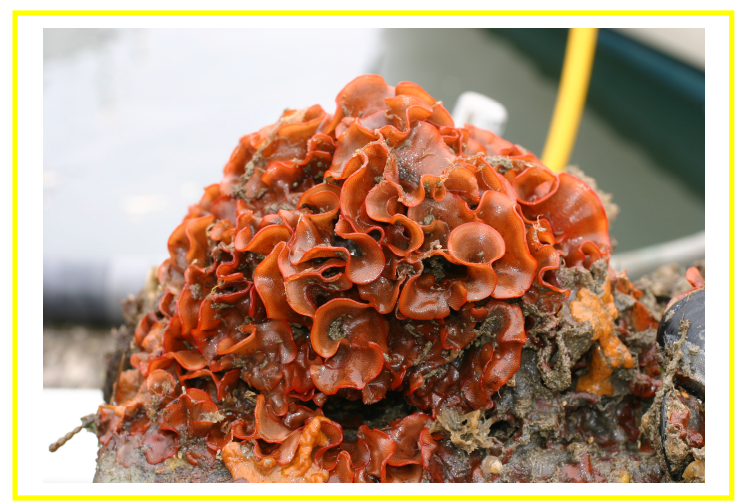

Bryozoan (Watersipora subtorquata)

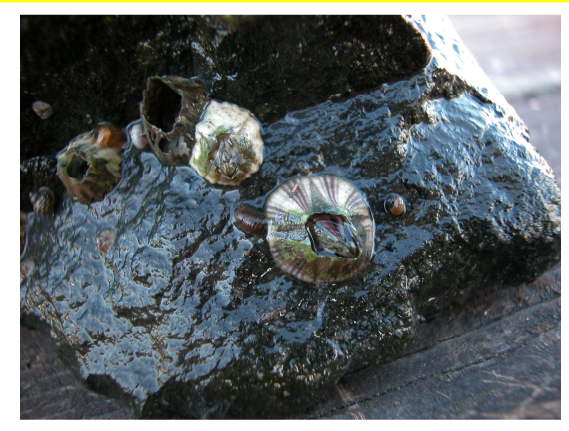

Barnacles (Balanus amphitrite)

Leigh Johnson, Jamie Gonzalez, Cesar Alvarez, Miki Takada, Amber Himes University of California Cooperative Extension - Sea Grant Extension Program San Diego, CA

Stephanie Showalter and Jason Savarese National Sea Grant Law Center, University, MS

ANR Publication 8359 - California Sea Grant College Program Report Number T-061 (c) Regents of the University of California, December 2007
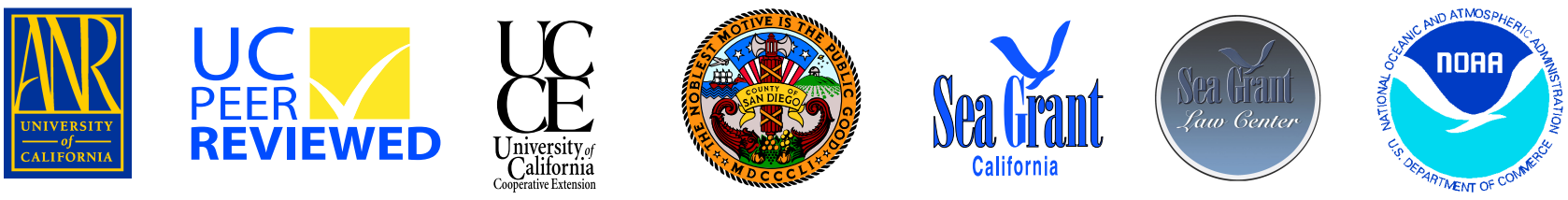


\section{Table of Contents}

Acknowledgments

I. Introduction

II. Biodiversity and Bioinvasions

III. Vessels as Vectors of Aquatic Invasive Species, Factors Influencing Invasions and Collaborations to Prevent Aquatic Bioinvasions

IV. Risk of Transporting Aquatic Invasive Species on Hulls of Boats Traveling in California and Baja California

V. Why Aquatic Invasive Species due to Boating and Shipping are a Problem Introduction

VI. Hull-Borne, Aquatic Invasive Species and Their Impacts

VII. Aquatic Invasive Species Transported by Other Means and Their Impacts

VIII. Risk-Management Strategies for Aquatic Invasive Species

IX. Antifouling Paints, Pollution and Bioinvasions - Ecology, Laws, Technologies, Practices, Conflicts and Resolutions

X. Restrictions on the Use of Marine Antifouling Paints Containing Tributyltin and Copper

XI. The Existing U.S. Legal Regime to Prevent the Hull Transport of Aquatic Invasive Species

XII. Recommendations and Conclusions

Appendices

A. Definitions

B. Aquatic Invasive Species Transported on Hulls

C. English/Spanish and Spanish/English Dictionary of Technical Terms

D. Popular California Boating and Fishing Sites

E. Popular Northwestern Mexico Boating and Fishing Sites

F. Recommendations from May 11, 2005 Workshop, "Managing Hull Transport of Aquatic Invasive Species" 


\section{Acknowledgments}

\section{Managing Hull-Borne Invasive Species and Coastal Water Quality for California and Baja California Boats Kept in Saltwater}

ANR Publication 8359 - California Sea Grant College Program Report Number T-061

ISBN-13: 978-1-60107-612-0

Authors: Leigh Johnson, Jamie Gonzalez, Cesar Alvarez, Miki Takada and Amber Himes, University of California Cooperative Extension - Sea Grant Extension Program, San Diego, CA Stephanie Showalter and Jason Savarese, National Sea Grant Law Center, University, MS

(C) Regents of the University of California, December 2007

Copies available from: Leigh Johnson, Marine Advisor, University of California Cooperative Extension Sea Grant Extension Program; County of San Diego MS O-18; 5555 Overland Avenue, Suite 4101; San Diego, CA 92123 (858) 694-2845 http://seagrant.ucdavis.edu

Also available from: California Sea Grant College Program, University of California, 9500 Gilman Drive, La Jolla, CA 92093-0232 (858) 534-4446

\section{Photographs taken by and reprinted with permission of:}

Bryozoan (Watersipora subtorquata), Luis Solorzano, www.californiabiota.com Barnacles (Balanus amphitrite), Andrew Cohen, San Francisco Estuary Institute, Oakland, CA Tubeworms (Hydroides sp.) and Sea Squirts (Ciona sp.), Cesar Alvarez, University of California Cooperative Extension - Sea Grant Extension Program

We would like to thank the following people for their review, advice, assistance, and support: This paper does not necessarily reflect the views of persons acknowledged.

Guillermo Acosta, Fondo Nacional de Fomento al Turismo (FONATUR), Mexico City, Mexico Verónica Aguilar, Comisión Nacional para el Conocimiento y Uso de la Biodiversidad (CONABIO), Mexico City, Mexico Yoal Aguilar-Hernández, Administración Portuaria Integral de Ensenada, Ensenada, Mexico Luís Ernesto Aguilar-Rosas, Universidad Autónoma de Baja California, Ensenada, Mexico Raúl Aguilar-Rosas, Universidad Autónoma de Baja California, Ensenada, Mexico Darlene Alari, University of California Agriculture and Natural Resources, Riverside, CA Rolando Bastida-Zavala, Universidad Del Mar, Puerto Angel, Mexico

Kim Beaird, University of California Sea Grant Extension Program, Davis, CA

Carol Berman, University of California Agriculture and Natural Resources, Oakland, CA

Mary Bernardy, University of California Agriculture and Natural Resources, Riverside, CA

David Breninger, Recreational Boaters of California, Auburn, CA

Robin Briggs, Bottom Liner, Long Beach, CA

Carrie Campbell, Clean Seas Company, Jacksonville, FL

Kathy Carrington, University of California Agriculture and Natural Resources, Riverside, CA

Jodi Cassell, University of California Sea Grant Extension Program, San Bruno, CA

Guillermina Chi-Barroigan, Universidad Autónoma de Baja California, Ensenada, Mexico

Andrew Cohen, San Francisco Estuary Institute, Oakland, CA

Ashley Coutts, Cawthron Institute, Nelson, New Zealand

Carrie Culver, University of California Sea Grant Extension Program, Ventura, CA

Luis Cruz, Environmental Protection Agency, Washington DC

Lynn Deetz, University of California Agriculture and Natural Resources, Oakland, CA

Jeff DeVaney, Global Source Advantage, San Diego, CA

Lesley Dobalian, California Regional Water Quality Control Board-San Diego Region, San Diego, CA

Diane Edwards, California State Water Resources Control Board, Sacramento, CA 
Susan Ellis, California Department of Fish and Game, Sacramento, CA

Bert Ewert, Miramar Landfill, San Diego, CA

Maurya Falkner, California State Lands Commission, Sacramento, CA

Kristin Feindel, Oregon State Marine Board, Salem, OR

Linda Fernandez, University of California, Riverside, CA

Tomás Fernández, Baja Naval, Ensenada, Mexico

Sylvain Fillion, Akzo Nobel, International Paint, Houston, TX

Reinhart (Ron) Flick, California Department of Boating and Waterways, La Jolla, CA

Oliver Floerl, National Institute of Water and Atmospheric Research, Riccarton, New Zealand

Joann Furse, California Sea Grant College Program, La Jolla, CA

Kirk Galarno, City of San Diego Environmental Services Department, San Diego, CA

Fernando García-Pamanes, Universidad Autónoma de Baja California, Ensenada, Mexico

Marsha Gear, California Sea Grant College Program, La Jolla, CA

Cassandra Gie, University of California Agriculture and Natural Resources, Riverside, CA

Cheryl Gneckow, University of California Agriculture and Natural Resources, Riverside, CA

Scott Godwin, B.P. Bishop Museum, Department of Natural Science, Honolulu, HI

Refugio (Cuco) Gonzalez, University of California Agriculture and Natural Resources, Riverside, CA

Myriam Grajales-Hall, University of California Agriculture and Natural Resources, Riverside, CA

Juan Guerrero, University of California Cooperative Extension, Holtville, CA

Susan Hackbarth, University of California Agriculture and Natural Resources, Riverside, CA

Alex Halston, San Diego Diving Services, San Diego, CA

Leslie Harris, Natural History Museum of Los Angeles County, Los Angeles, CA

Elizabeth Haslbeck, Naval Surface Warfare Center, West Bethesda, MD

Paul Heimowitz, United States Fish and Wildlife Service, Portland, OR

Marlan Hoffman, California Marine Services, San Diego, CA

Eric Holm, Naval Surface Warfare Center, West Bethesda, MD

K. Avivah Jacob, United States Environmental Agency, Washington, DC

Andrew Jirik, Port of Los Angeles, San Pedro, CA

David Johnson, California Department of Boating and Waterways, Sacramento, CA

Toroshinia Kennedy, County of San Diego Farm and Home Advisor Department, San Diego, CA

Kenneth Kimmel, University of California Sea Grant Extension Program, Davis, CA

Richard Kittar, Aurora Marine Industries Inc., Mississauga, Canada

Janelle Kohl, University of California Sea Grant Extension Program, Davis, CA

Colin Levings, Fisheries and Oceans, Vancouver, Canada

Larry Lovell, Scripps Institution of Oceanography, La Jolla, CA

Laura Martínez-Ríos del Río, Pro Esteros, Ensenada, Mexico

Tamara Mason, University of California Agriculture and Natural Resources, Riverside, CA

Vivian Matuk, California Coastal Commission, San Francisco, CA

Karen McDowell, San Francisco Estuary Project, Oakland, CA

Valerie Mellano, University of California Agriculture and Natural Resources, San Diego, CA

Russ Moll, California Sea Grant College Program, La Jolla, CA

Wayne Morrison, Shelter Island Boatyard, San Diego, CA

Peter Neimanis, Australian Quarantine and Immigration Service, Canberra, Australia

Tom Nielsen, Nielsen Beaumont Marine, San Diego, CA

Filiberto Núñez-Cebrero, Universidad Autónoma de Baja California, Ensenada, Mexico

Paul Olin, University of California Sea Grant Extension Program, Santa Rosa, CA

Deborah Pennell, Shelter Island Marina, San Diego, CA

Stephen Phillips, Pacific States Marine Fisheries Commission, Portland, OR

Carrie Pomeroy, University of California Sea Grant Extension Program, Watsonville, CA

Bettina Proctor, U.S. Fish and Wildlife Service, Denver, CO

Sandy Purdon, California of Boating and Waterways Commission, San Diego, CA

Bill Rashick, Alpha One Diving, San Diego, CA

Karen Renne, University of California Agriculture and Natural Resources, Riverside, CA 
Bill Roberts, Shelter Island Boatyard, San Diego, CA

Greg Ruiz, Smithsonian Environmental Research Center, Edgewater, MD

Terry Salmon, University of California Cooperative Extension, San Diego, CA

Dragan Samardzic, Matson Navigation, Oakland, CA

Laura Schulte, University of California Agriculture and Natural Resources, Riverside, CA

Don Schulz, Surfrider Foundation - Huntington Beach/Seal Beach Chapter, CA

Stephanie Showalter, National Sea Grant Law Center, University, MS

Bruce Sifton, 21st Century Coatings, Vancouver, Canada

Nan Singhasemanon, California Department of Pesticide Regulation, Sacramento, CA

Tony Snell, Australian Quarantine and Inspection Services, Canberra, Australia

Luis Solorzano, U.S. Food and Drug Administration, Alameda, CA

Joe Starinchack, U.S. Fish and Wildlife Service, Arlington, VA

Lynn Takata, California State Lands Commission, Sacramento, CA

Wendi Tapia, University of California Agriculture and Natural Resources, Riverside, CA

Pat Torrealba, University of California Agriculture and Natural Resources, Riverside, CA

Raynor Tsuneyoshi (Director), California Department of Boating and Waterways, Sacramento, CA

Alana Valencia, University of California Agriculture and Natural Resources, Riverside, CA

M'K Veloz, Northern California Marine Association, Berkeley, CA

Ted Warburton, Brisbane Marina, Brisbane, CA

Steve Watanabe, California Department of Boating and Waterways, Sacramento, CA

Neil Wilson, Driscoll Boat Works, San Diego, CA

Lisa Wood, City of San Diego Environmental Services Department, San Diego, CA

\section{We would also like to thank those who participated in the Workshop on Managing Hull Transport of Aquatic Invasive Species on May 11, 2005 in San Francisco, CA.}

This publication was supported in part by the California Department of Boating and Waterways Project No. 04-106111, the California Policy Research Center Project No.EEN03A, the U.S. Department of Agriculture's Renewal Resources Extension Act Projects No. 05-24 and No. 06-04, the Western Regional Panel of the Aquatic Nuisance Species Task Force through the Pacific States Marine Fisheries Commission Project No. 05-73, the California State Lands Commission, National Sea Grant College Program of the U.S. Department of Commerce's National Oceanic and Atmospheric Administration under NOAA Grant \#NA04OAR4170038, Project number A/E-1 through the California Sea Grant College Program, and in part by the California State Resources Agency, the University of California Sea Grant Extension Program, Regents of University of California, the University of California Agriculture and Natural Resources and Cooperative Extension, and the County of San Diego. The views expressed herein do not necessarily reflect the view of any of those organizations.

The University of California prohibits discrimination or harassment of any person on the basis of race, color, national origin, religion, sex, gender identity, pregnancy (including childbirth, and medical conditions related to pregnancy or childbirth), physical or mental disability, medical condition (cancer-related or genetic characteristics), ancestry, marital status, age, sexual orientation, citizenship, or service in the uniformed services (as defined by the Uniformed Services Employment and Reemployment Rights Act of 1994: service in the uniformed services includes membership, application for membership, performance of service, application for service, or obligation for service in the uniformed services) in any of its programs or activities.

University policy also prohibits reprisal or retaliation against any person in any of its programs or activities for making a complaint of discrimination or sexual harassment or for using or participating in the investigation or resolution process of any such complaint.

University policy is intended to be consistent with the provisions of applicable State and Federal laws. Inquiries regarding the University's nondiscrimination policies may be directed to the Affirmative Action/Equal Opportunity Director, University of California, Agriculture and Natural Resources, 1111 Franklin Street, $6^{\text {th }}$ Floor, Oakland, CA 94607, (510) 987-0096. 


\section{Introduction}

This report will focus on invasive species transported on hulls of boats kept in saltwater. Although the focus is on California and Baja California, information from other areas has been included to provide context.

The report is intended to assist the following groups in cooperating to prevent and control introductions of aquatic invasive species (AIS) on hulls of boats, while protecting coastal water quality:

- boat owners;

- boat maintenance, repair and coating businesses;

- port, harbor, marina and yacht club managers;

- scientists;

- policy makers

- government agencies; and

- environmental organizations.

Recreational boats that are generally kept in saltwater, removed only for maintenance and travel by sea from one location to another are the focus of this report. Some findings may also be suitable for commercial fishing and commercialpassenger fishing boats. Recommendations and resources for controlling AIS on trailered boats are available from the excellent Stop Aquatic Hitchhikers! website at http://protectyourwaters.net/. The California State Lands Commission has developed recommendations for commercial ships. ${ }^{1}$ Other organizations are working on controlling transport of AIS by other vectors and research scientists may continue to find new vectors.

Fouling growth creates problems for ships and boats by making hulls rougher and creating friction ("drag") that slows them or increases fuel consumption. Ships and boats may also carry invasive species on their hulls.

When is a non-native fouling organism invasive? Fouling occurs when marine microbes, plants, and animals, and/or their spores and larvae attach and grow on the hull of a boat or ship. If they survive the trip to a distant harbor, they may spawn, release spores, or be removed and discarded there. If they succeed in the new area, they may create problems. For example, they may: out-compete local species for food; overgrow them and alter their habitat; damage shorelines and structures; cause new diseases for humans and marine life; and be expensive to control or eradicate. ${ }^{23}$

A species that crowds out competitors and dominates an area reduces the diversity of its marine life. The importance of biological diversity is explained more fully in Section II. The invasive strain of the green alga, Caulerpa taxifolia, has overgrown thousands of acres of Mediterranean Sea bottom and displaced many other species of marine life. In 2000-2005 US\$4.5 million was spent to eradicate $C$. taxifolia from Agua Hedionda Lagoon in San Diego County and Huntington Harbor in neighboring Orange County and to continue monitoring efforts. ${ }^{4}$

The European green crab (Carcinus maenas) competes with the native and commercially important Dungeness crab (Cancer magister) from Central California to British Columbia. ${ }^{5}$ It also feeds on cultured oysters, mussels and native clams, enters and fills traps for eels and bait fish, and is believed to have caused the collapse of the soft clam fishery on the United States' East Coast. $C$. maenus is thought to have reached the United States as early larval stages on ship hulls or among rocks and mud used as solid ballast. It was found in California in the 
1980s. 678910 However, contaminated marine bait is believed to be the likely source for its introduction in California. ${ }^{11} 12$

Boating and other forms of coastal tourism contribute much economic productivity. For example the California boating industry was worth US\$16 billion (1.2\% of the State Gross Product) in 2000. ${ }^{13}$ Many coastal residents and tourists enjoy watching birds and whales, photographing nature, fishing, boating, water sports and relaxing in natural surroundings. If AIS crowd out native species and lower biodiversity, they could degrade the recreational value of coastal ecosystems. $^{14}$

The U.S. Commission on Ocean Policy, the Pew Oceans Commission and the California Governor's Ocean Action Strategy all target AIS as a major challenge facing our coastal oceans. The rate of new aquatic bioinvasions continues to increase along with growth in global trade, travel and transportation. Thus, we cannot assume that all possible, hullborne invasions have already occurred. ${ }^{15} 16$ 17

Ships are clearly responsible for most, longdistance transport of AIS, although some pleasure craft have introduced invaders from overseas. For example, the black-striped mussel, a relative of the infamous zebra mussel, arrived at Darwin, Australia on a yacht. Au\$2.2 million was spent in 1999 to eradicate it from three Darwin marinas. ${ }^{18}$

For the most part, however, recreational boats are believed to move AIS along the coast. AIS from San Francisco Bay are found in Elkhorn Slough, which drains into Monterey Bay. Scientists believe small craft, such as commercial fishing and pleasure boats, are likely to have brought them from San Francisco Bay, where commercial ships dock. ${ }^{19}$ Thus, pleasure and fishing boats may spread AIS by visiting ports frequented by commercial ships, by attending events or fishing on grounds that attract boats from many areas, and by cruising along the coast.

Preventing introductions of AIS is generally less expensive and more effective than controlling them. ${ }^{20} \mathrm{We}$ have observed that pleasure craft tend to spend most of their time in home-port slips and environs, where fouling growth will not be carried to new areas or brought in from other areas. Therefore, it may be most cost effective to prevent AIS transport by cleaning hulls before boats travel beyond their home port, before they move to another region and before they return home. Additional measures will be needed to prevent introductions of new species by fouled boats returning from a long trip.

Commercial fishing and commercialpassenger fishing boats share some features of commercial shipping: they travel often and some go to distant fishing grounds. They also share some features of recreational boats: they may spend much time within a region and many are small craft, whose underwater structures are more like those of pleasure craft than commercial cargo ships, tugs and barges. An analysis of their movement patterns and appropriate means for controlling AIS on their hulls is needed but is beyond the scope of this report. However, some of the issues and preventive measures suggested here may apply to them.

Toxic, antifouling paints are pesticides used to control fouling growth. At first glance they would seem to be the solution to controlling AIS on vessel hulls. However, they slow, rather than prevent, fouling. They also create a water quality problem. Further, there is growing evidence that invasive, fouling species are more tolerant of copper 
than native species. ${ }^{2122} 23$ Thus, antifouling paints cannot be expected to solve the problem of hull-borne, invasive species.

Most antifouling paints contain a heavy metal toxicant that is designed to leach. These metals can accumulate in the water of crowded, poorly flushed marinas to levels that harm marine life. As a result, tributyl tin-based antifoulants have long been banned for recreational boats and are being phased out worldwide for vessels making international voyages. Copper-based antifoulants have been banned for recreational boats in parts of northern Europe. In 2005, the California State Water Resources Control Board approved a Total Maximum Daily Load (TMDL) regulatory program for Shelter Island Yacht Basin in northern San Diego Bay. Similar TMDL programs are being prepared for Newport Bay and Marina Del Rey in neighboring Orange and Los Angeles Counties. The San Diego program will require reduction of copper discharges from recreational boats over a 17-year period. These points are discussed and documented in Section IX of this report.

In 1999, we began a research and education program to assist boaters, boating and coating businesses, and academic, governmental and environmental organizations in reducing pollution from antifouling paints. We conducted a field demonstration and economic analysis of nontoxic antifouling strategies, published reports and a video documentary, and conducted seminars. We found that durable, epoxy, nontoxic coatings can last much longer than copper-based antifouling paints. Thus, they can be more cost-effective over time, despite costs to convert from copperbased paints and the twice-as-frequent hull cleaning that is needed to control fouling growth. Storing the boat out of water and using a slip liner can reduce hull-cleaning costs. However, some harbor masters have commented that slip liners may pose problems, such as fouling of the outside of the liner and potential release of chlorine that some boaters add to the water in the liner to keep it clean. See Section IX for more information on slip liners. New products are under development and coming onto the market. Those that prove to be effective and economical will increase the number of alternatives to copper-based antifoulants in coming years. ${ }^{24} 25$ Buyers should investigate new products carefully by asking boat repair and maintenance businesses and boating associations about experiences with them in the area where they will be used.

When we learned of concerns that AIS could be transported on boat bottoms, we realized the potential for conflict between policies to reduce pollution from antifouling paints and policies to control hull-borne invasive species. Thus, the information in this report is intended to:

- Educate the reader about aquatic invasive species with a primary focus on transport of coastal, marine species on boat bottoms in California;

- Explain biodiversity, why it is important and how bioinvasions affect it;

- Summarize boat traffic patterns along the coasts of California and Baja California because of extensive, regional, boating activity;

- Explain why invasive species, including those on boat bottoms, are a problem and give examples of structural, socioeconomic, and ecological impacts;

- Review laws, regulations, and agencies governing control of hull-borne invasive species and fouling growth;

- Discuss the interplay of antifouling laws with water quality and aquatic invasive species policies; 
- Present hull-fouling control techniques;

- Recommend research, education and management measures that may help to control aquatic invasive species, while protecting coastal water quality; and

- Draw conclusions.

Appendices include:

- List of aquatic invasive species that foul hulls;

- Definitions related to aquatic invasive species;

- List of terms in English and Spanish;

- Boating map of California;

- Boating map of Baja California;

- Recommendations of May 11, 2005 Workshop: "Managing Hull Transport of Aquatic Invasive Species" (on ships and boats).

\section{Navigating this Document}

Please notice the set of tabs at the left side of this document. To move among the sections and appendices of the main report, click the Bookmarks tab and then click the Adobe ${ }^{\mathrm{TM}}$ symbol beside the name of the section or appendix you wish to read.

\section{References}

${ }^{1}$ Takata, L., M. Falkner and S. Gilmore. 2006. Commercial Vessel Fouling in California: Analysis, Evaluation, and Recommendations to Reduce Nonindigenous Species Release from the Non-Ballast Water Vector. Produced for the California State Legislature. California State Lands Commission, Marine Facilities Division, Sacramento, CA. April 2006. 83 p.

${ }^{2}$ Carlton, J.T. 2001. Introduced Species in U.S. Coastal Waters: Environmental Impacts and Management Priorities. Pew Oceans Commission, Arlington, VA.

${ }^{3}$ Bax, N., A. Williamson, M. Aguero, E. Gonzalez and W. Geeves. 2003. Marine invasive alien species: a threat to global biodiversity. Marine Policy 27:313323.

${ }^{4}$ Carlton, J.T. 2001. Introduced Species in U.S.

Coastal Waters: Environmental Impacts and
Management Priorities. Pew Oceans Commission, Arlington, Virginia.

5 Washington Department of Fish and Wildlife Aquatic Nuisance Species: European Green Crab (Carcinus maenas) http://wdfw.wa.gov/fish/ans/greencrab.htm\#impacts Accessed April 30, 2006.

${ }^{6}$ Meacham, P. 2001. Washington State Aquatic Nuisance Species Management Plan. Washington Department of Fish and Wildlife for the Washington Aquatic Nuisance Species Coordinating Committee.

${ }^{7}$ Cohen, A.N. 2005. Guide to the Exotic Species of San Francisco Bay. San Francisco Estuary Institute. Oakland, CA. www.exoticsguide.org Accessed August 30, 2005.

${ }^{8}$ Grosholz, E.D., G.M. Ruiz, C.A. Dean, K.A. Shirley, J.L. Maron and P.G. Connors. 2000. The impacts of a Nonindigenous Marine Predator in a California Bay. Ecology 81(5):1206-1224.

${ }^{9}$ Cohen, A.N. 2005. Guide to the Exotic Species of San Francisco Bay. San Francisco Estuary Institute. Oakland, CA. www.exoticsguide.org Accessed August 30, 2005.

${ }^{10}$ California State University, Sacramento Foundation. 2002. California Boating Facilities Needs Assessment. Volume V: Boating Economic Assessment and Demand Projections. California Department of Boating and Waterways, Sacramento, CA.

${ }^{11}$ The Ocean Conservancy: Invasive Species. http://www.oceanconservancy.org/site/PageServer?p agename=issues_species Accessed February 3, 2006.

${ }^{12}$ Benson, A.J. and P.L. Fuller. 1999. Nonindigenous Crustaceans in the United States.

http://cars.er.usgs.gov/posters/Nonindigenous/Nonind igenous_Crustaceans/non-

indigenous_crustaceans.html Accessed February 3, 2006. United States Geological Survey: Biological Resources

Florida Integrated Science Center. Presented at the Zebra Mussel and Other Aquatic Nuisance Species Conference. Duluth, MN. April 1999.

${ }^{13}$ California State University, Sacramento Foundation. 2002. California Boating Facilities Needs Assessment. Volume V: Boating Economic Assessment and Demand Projections. California Department of Boating and Waterways, Sacramento, CA.

${ }^{14}$ Peterson, C.H. and J. Lubchenco. 1997. Marine Ecosystem Services. In: G.C. Daily, ed. Nature's Services: Societal Dependence on Natural Ecosystems. p. 177-194. Island Press, Washington, DC.

${ }^{15}$ U.S. Commission on Ocean Policy. 2004.

Preliminary Report of the U.S. Commission on 
Ocean Policy Governor's Draft, Washington, DC, April 2004.

${ }^{16}$ Carlton, J.T. 2001. Introduced Species in U.S. Coastal Waters: Environmental Impacts and Management Priorities. Pew Oceans Commission, Arlington, VA.

${ }^{17}$ California Resources Agency and California Environmental Protection Agency. 2004. Protecting

Our Ocean: California's Action Strategy. Final Report to Governor Arnold Schwarzenegger. September 2004. Sacramento, CA.

${ }^{18}$ Bax, N., A. Williamson, M. Aguero, E. Gonzalez and W. Geeves. 2003. Marine invasive alien species: a threat to global biodiversity. Marine Policy 27:313323.

${ }^{19}$ Wasson, K., C.J. Zabin, L.Bedinger, M.C. Diaz and J.S. Pearse. 2001. Biological invasions of estuaries without international shipping: the importance of intraregional transport. Biological Conservation 102:143-153.

${ }^{20}$ Bax, N., A. Williamson, M. Aguero, E. Gonzalez and W. Geeves. 2003. Marine invasive alien species: a threat to global biodiversity. Marine Policy 27:313323.

${ }^{21}$ Hall, A. 1981. Copper accumulation in copper tolerant and non-tolerant populations of the marine fouling alga, Ectocarpus siliculosus (Dillwyn) Lyngbye. Botanic Marina 24:223-228.

${ }^{22}$ Russell, G. and O.P. Morris. 1973. Ship fouling as an evolutionary process. Proceedings of the $3^{\text {rd }}$ International Congress of Marine Corrosion and Fouling: 719-730. Washington, DC, 1972.

${ }^{23}$ Crooks, J. 2005. Oral commentary. Vessel Fouling Technical Advisory Group, October 13, 2005: Meeting Summary. California State Lands Commission, Sacramento, CA.

${ }^{24}$ Johnson, L.T. and J.A.Gonzalez. 2004. Staying Afloat with Nontoxic Antifouling Strategies for Boats. California Sea Grant College Program Report No. T054. $21 \mathrm{p}$.

${ }^{25}$ Johnson, L.T. and J.A. Miller. 2003. Making Dollars and Sense of Nontoxic Antifouling Strategies for Boats. California Sea Grant College Program Report No. T-052. 13 p. 


\section{Biodiversity and Bioinvasions}

The concept of biodiversity refers to the variety of life on three different levels: genetic diversity; species diversity; and ecosystem diversity.

Biological diversity is the

- variety of species,

- genetic variability within them, and

- varied ecosystems they inhabit.

The variety of species takes into account the number of different species and the equitability with which they are distributed. Genetic variation within a species might provide greater disease resistance to some and greater speed to others; it is the foundation of species adaptability to shifting environments. ${ }^{1}$ If there is more genetic variability among the members of a species, there is a better chance that at least some will survive challenges, such as epidemics or new predators. Biodiversity also applies to the variety of plants, animals and microbes living in a type of habitat, such as a kelp forest or estuary. It may also describe variety in a geographic region, such as the Southern California coast or San Francisco Bay. $^{2}$

The following principles are helpful in understanding biodiversity:

- Habitat diversity promotes species diversity. For example, a mixed area of sand, rocks and reefs has a relatively high biological diversity, because more species can find suitable shelter and food than would be possible in an area with only one type of physical habitat.

- Species diversity is self-reinforcing. Increasing diversity in species stimulates further increases in diversity. For example, more species of marine algae may support a greater variety of species that feed on algae.
- Moderate levels of physical disturbance, such as periods of low salinity and moderate nutrient deficiencies, may promote local diversity by preventing a few highly competitive species from dominating an area. ${ }^{3}$

- Geographic isolation allows unique species to develop in the absence of competition. ${ }^{4}$

Thus, species that humans value depend on diverse habitats, a diverse group of other species, some periodic physical disturbance, and some degree of geographic isolation. Examples of important species include: those that provide food for species we enjoy viewing, catching or eating; predator species that keep prey species healthy by removing the weak and preventing overpopulation; and decomposers that release nutrients from the remains of other species.

\section{Socio-Economics of Biodiversity}

Biodiversity has social and economic value. For example, the ambience created by natural areas with diverse plants and animals provides opportunities for non-consumptive uses, such as wildlife viewing, outdoor recreation and the relaxing contemplation of nature. Such uses also support valuable recreation and tourism industries, such as the California boating industry, which was worth $\$ 16.5$ billion in 2000 . $^{5}$ Indigenous peoples depend on certain species to maintain their traditional livelihoods and unique cultures. Effects of coastal storms are mediated by resilient seagrass and kelp beds and by coastal marshes and swamps.

The importance of biological diversity in satisfying basic human needs and in promoting human development was recognized in the "Convention on Biological Diversity.” This document was produced at an international conference held in Rio de 
Janeiro, Brazil in 1992. The Convention states, "Our need for pieces of nature we once ignored is often important and unpredictable. Time after time we have rushed back to nature's cupboard for cures to illnesses or for infusions of tough genes from wild plants to save our crops from pest outbreaks." ${ }^{, 6}$ Biodiversity offers the promise of new products that will enhance the quality and longevity of human life.

Marine organisms, from microbes and bacteria that live in the sediment to marine invertebrates, such as sponges and bryozoans, and algae are well known for producing compounds that show promise in treating a variety of medical conditions, including cancer, neurogenic inflammation and rheumatoid arthritis. ${ }^{78}$

Invertebrate species living on hard bottoms of the Southern California coast were recently screened for medicinal value by Dr. William Fenical's team at Scripps Institution of Oceanography at University of California, San Diego. They concluded, "Several of our samples yielded novel and exciting compounds...Southern California is a wellspring for bioactive marine invertebrates that has been long overlooked. The rocky intertidal zones and kelp forests unique to California serve as a haven for sponges, ascidians, and opisthobranch molluscs."

One such example is Laurencia pacifica, which is abundant along the Southern California coast. ${ }^{10}$ This red alga produces halogenated terpenes, which are the biogenic precursors of many bioactive metabolites. ${ }^{11}$

${ }^{12}$ Other examples are the sponge, Haliclona lunisimilis, and the dorid nudibranch, Diaulula sandiegensis, which were found to contain anticancer compounds, ${ }^{1314}$ as well as the sea hare, Aplysia kurodai, which contains the anticancer agent Aplyronine A. ${ }^{15}$ Because many of these potentially important animals and seaweeds inhabit rocks, piers, and boat bottoms, especially along California's coastline, there is a risk that invasive fouling species could displace these native species and significantly decrease the possibilities for finding new pharmaceutical products.

More than half of the United States' population lives and works within 50 miles of the coastline, but coastal areas account for only 11 percent of the nation's land area. In recent years, 40 percent of new commercial development and 46 percent of new residential development has occurred near the coast. ${ }^{16}$ The coastal zone contains most of the infrastructure for marine recreation and tourism, the ports and harbors, and the urban, resort and industrial development in the United States. Because biodiversity provides natural resources and aesthetic values, it is essential to coastal economies and quality of life. Thus, biodiversity must be considered in planning and implementing development, especially in environmentally sensitive coastal areas.

\section{Biodiversity and Bioinvasions}

High biodiversity arose on our planet when species were separated on isolated areas of land or sea. This is how, for example, different cereal grains originated in different parts of the world - wheat in the Middle East, rice in the Far East and corn in the Americas. A well known example of the role of geographic isolation in biodiversity is the large variety of bird species found in the Galapagos Islands. As humans transport species across the globe, inevitably some new arrivals displace natives. Scientists who study invasion biology fear that this process could lead to a day when the Earth has many fewer species than it does now - a "homogenized world." 171819 
Together, bioinvasions and habitat destruction have been major causes of species extinctions throughout the world in the past few hundred years. Aquatic invasive species can have significant undesirable impacts on ecosystems by causing a loss of biodiversity. ${ }^{20}$ This irretrievable loss of biodiversity is one of the ecological costs of biological invasions. ${ }^{21}$

Scientists have extensively documented the importance of habitat loss as a threat to biodiversity. For example development of natural areas in San Diego County, California has reduced diversity of flora and fauna and threatened some species with extinction. ${ }^{22}$ However, as understanding of bioinvasions has grown, some scientists have come to believe that invasive species have an even greater impact on biodiversity than habitat loss does. ${ }^{23}{ }^{24}$ Effects on biodiversity and resulting ecological and socio-economic impacts will be discussed in Sections V, VI and VII of this report. Some scientists believe that ecosystems with high biodiversity may be more resistant to bioinvasions. In a study of experimentally assembled communities, decreasing native diversity increased the survival of invaders. Increasing native diversity decreased open space that could accommodate invaders. ${ }^{25}$ Pollution may affect biodiversity by favoring species that are more tolerant of it. The role of pollution in the balance between native and invasive species will be discussed in Section IX of this report.

\section{References}

\footnotetext{
${ }^{1}$ Simon, D. 2007. Biodiversity in the National Parks: Looming Threats to America's Most Valued Plants and Animals

http://www.npca.org/wildlife_protection/biodiversity/ report/biodiversity.html Accessed February 22, 2007.

${ }^{2}$ Daily, G.C., ed. 1997. Nature's Services: Societal Dependence on Natural Ecosystems. Island Press: Washington, DC. $x x+391 \mathrm{p}$.
}

${ }^{3}$ Van Driesche, J. and R. Van Driesche. 2004. Nature out of place: Biological invasions in the global age. Part One: The globalization of nature. Island Press: Washington.

${ }^{4}$ MacArthur, R.H. and E.O. Wilson. 1967. The Theory of Island Biogeography. Monographs in Population Biology 1. Princeton University Press: Princeton, NJ. 203 p.

${ }^{5}$ California State University, Sacramento Foundation. 2002. California Boating Facilities Needs Assessment. Volume V: Boating Economic Assessment and Demand Projections. California Department of Boating and Waterways, Sacramento, CA.

${ }^{6}$ Secretariat of the Convention on Biological

Diversity. 2000. How the Convention on Biological Diversity Promotes Nature and Human Well-Being. Secretariat of the Convention on Biological Diversity with the Support of the United Nations Environment Programme and the financial support of the Government of the United Kingdom.

${ }^{7}$ Faulkner, D.J. 2000. Marine pharmacology. Antonie van Leeuwenhoek 77:135-145.

${ }^{8}$ Fenical, W.H. 2005. The biomedical potential of California marine organisms (March 11, 2005).

California Sea Grant College Program. Research Completion Reports, Paper NMP05_01. Accessed at: http://repositories.cdlib.org/csgc/rcr/NMP05_01.

${ }^{9}$ Fenical, W. 2005. The Biomedical Potential of California Marine Organisms. California Sea Grant College Program. Research Completion Reports. Paper NMP05_01. http://repositories.cdlib.org/csgc/rcr/NMP05_01 Accessed: October 25, 2005.

${ }^{10}$ Personal communication with Dr. William Fenical, March 16, 2006.

${ }^{11}$ Butler, A. 2005. Molecular approaches in marine pharmacology. California Sea Grant College Program. Research Completion Reports, Paper NMP05-02. Accessed at: http://repositories.cdlib.org/csgc/rcr/NMP05_02.

${ }^{12}$ Carter-Franklin, J.N. and A. Butler 2004. Vanadium bromoperoxidase-catalyzed biosynthesis of halogenated marine natural products. J Am Chem Soc. 2004 Nov 24;126(46):15060-6.

${ }^{13}$ Fenical, W.H. 2005. The biomedical potential of California marine organisms (March 11, 2005). California Sea Grant College Program. Research Completion Reports, Paper NMP05_01. Accessed at: http://repositories.cdlib.org/csgc/rcr/NMP05_01.

${ }^{14}$ Faulkner, D.J. and W.H. Fenical 2005. The biomedical potential of California marine organisms. California Sea Grant College Program. Research Profiles, Paper PPNMP05-02. Accessed at: http://repositories.cdlib.org/csgc/rp/PPNMP05_02. 
${ }^{15}$ Nuijen, B. M. Bouma, C. Manada, J.M. Jimeno, J.H.M. Schellens, A. Bult and J.H. Beijnen. 2000. Pharmaceutical development of anticancer agents derived from marine sources. Anti-Cancer Drugs 11:793-811.

${ }^{16}$ NOAA. 2005. The International Year of the Ocean: Coastal Development Fact Sheet. http://www.yoto98.noaa.gov/facts/cdevel.htm Accessed August 24, 2005.

${ }^{17}$ MacArthur, R.H. and E.O. Wilson. 1967. The Theory of Island Biogeography. Monographs in Population Biology 1. Princeton University Press: Princeton, NJ. 203 p.

${ }^{18}$ Elton, C.S. 2000. The Ecology of Invasions by Animals and Plants with a new Foreword by D. Simberloff. The University of Chicago Press:

Chicago. xiv $+181 \mathrm{p}$.

${ }^{19}$ Burdick, A. Out of Eden: An Odyssey of Ecological Invasion. Farrar, Straus and Giroux: New York. 324p.

${ }^{20}$ Convention on Biological Diversity. Invasive Alien Species Introduction.

http://www.biodiv.org/programmes/crosscutting/alien/ Accessed October 4, 2005.

${ }^{21}$ The World Conservation Union: Species Survival Commission, Invasive Species Specialist Group. http://www.issg.org/ Accessed October 4, 2005.

${ }^{22}$ Davis, F. W., D.M. Stoms, P. Stine, A. Hollander, M. Borchert, M. Bueno, K. Beardsley, and V. Gray. 1994. Gap Analysis of the Southwestern California Region. Report Submitted to the National Fish and Wildlife Foundation and the Southern California Edison Company. Center for the Remote Sensing and Environmental Optics and Department of Geography, University of California, Santa Barbara. http://biology.usgs.gov/s+t/noframe/m3281.htm Accessed August 29, 2005.

${ }^{23}$ Vitousek, P.M. C. M. D’Antonio, L. L. Loope, M. Rejmanek and R. Westbrooks. 1997. Introduced Species: A Significant Component of Human-Caused Global Change. New Zealand Journal of Ecology 21(1):1-16.

${ }^{24}$ Convention on Biological Diversity, 2003. Pilot Assessments: The Ecological and Socio-Economic Impact of Invasive Alien Species on Island Ecosystems. Ninth Meeting, Montreal, QU, Canada, 10-14 November 2003.

${ }^{25}$ Stachowicz, J.J., H. Fried, R.W. Osman, and R.B. Whitlatch. 2001. Biodiversity, invasion resistance, and marine ecosystem function: Reconciling pattern and process. Ecology 83(9): 2575-2590. 


\section{Vessels as Vectors of Aquatic Invasive Species, Factors Influencing Invasions and Collaborations to Prevent Aquatic Bioinvasions}

\section{Vessels as Vectors of Aquatic Invasive Species}

Globalization of trade, travel, and transportation is greatly increasing the rate at which organisms are transported around the world, as well as the number and diversity of species being moved. ${ }^{1}$ In marine and estuarine environments, shipping has been the predominant vector for human transport of non-indigenous species around the world through hull fouling, ballast water and other means. 234567891011 The rate of invasion attributed to shipping has increased exponentially from the early 1800 s to the present. ${ }^{12}$ Hull fouling in particular contributes to aquatic invasive species (AIS) transport; the faster speed of modern ships may enhance survival of certain low-salinity species that would not survive as well under longer exposures to seawater. ${ }^{13}$ Slower moving vessels may allow increased survivorship of other invasive species on exposed, hull surfaces. For example, the barnacle, Chthamalus proteus, was probably introduced to Hawaii as larvae spawned from adults in a hull fouling community. ${ }^{14}$

In California, invasive species transported via vessel hulls disturb native habitats, affect biodiversity, and alter ecosystems. San Francisco Bay is considered the most invaded marine region in the world, and in 1998, had an average of one intruder every 14 weeks. ${ }^{15}$ Recreational boats play a major role in transporting AIS from harbors and estuaries associated with international ports to other areas along the coast. ${ }^{16}$

Marine invasive species can be introduced by recreational, commercial, and military vessels on hulls, anchors, and rudders, or in sea chests and ballast water. Live marine organisms ranging from plankton to adult fish are regularly introduced when ballast water is released into ports and harbors. ${ }^{17} 18$ U.S. Coast Guard regulations recommend that ships exchange ballast water at sea to prevent new introductions; ${ }^{19}$ many species transported in ballast water have already become established. ${ }^{20} 21$

Although the International Maritime Organization (IMO) has adopted guidelines for proper ballast water management, invasive species transfer by this vector is still a problem. The bacteria that causes cholera (Vibrio cholerae), and the fishhook waterflea (Cercopagis pengoi), European green crab (Carcinus maenas), Chinese mitten crab (Eriocheir sinensis), North American comb jelly (Mnemiopsis leidyi), Northern Pacific seastar (Asterias amurensis), round goby (Neogobius melanostomus), zebra mussel (Dreissena polymorpha), and Asian kelp (Undaria pinnatifida) are some of the well known invasive species associated with ballast water. $^{22}$

Recent studies suggest that fouling growth on vessel hulls is a significant vector for invasive species, possibly equal to ballast water. $^{2324252627}$

Species that foul vessel hulls are typical of natural, marine intertidal and subtidal fouling communities. Species commonly associated with marine fouling communities are arthropods (barnacles, amphipods, and crabs), molluscs (mussels, clams, and sea slugs), sponges, bryozoans, coelenterates (hydroids and anemones), protozoans, annelids (marine worms), and chordates (sea squirts and fish), as well as macroalgae (seaweed). If these fouling communities become highly developed they can also 
provide micro-habitats for mobile organisms such as fish. ${ }^{28}$ Initial settlement of fouling organisms tends to be in sheltered areas of the hull, such as sea-chest intakes and rudder posts, and in areas where antifouling coatings have been compromised. ${ }^{29} 30$

\section{Recreational Vessels}

Large estuaries with international shipping serve as sources for species that become invasive in other geographic regions. In other words, larger ships likely accomplish most of the long-distance transport while commercial fishing and recreational boats likely contribute to the transport of invasive species along the coast. For example, the burrowing isopod Sphaeroma quoyanum, which fosters shoreline erosion, originated in Australia and New Zealand and is now found in Elkhorn Slough, which drains into Monterey Bay, California. ${ }^{31}$ The isopod was first reported in San Francisco Bay in 1893, where it was likely introduced by larger ships, and rapidly spread throughout California bays and harbors, almost certainly via hull fouling on smaller vessels. ${ }^{32}$

The annual commercial fishing boat migration along the West Coast brings a temporary influx of boats to Monterey Bay (and other regional harbors) from Baja California to Alaska. ${ }^{33}$ Section IV of this report will discuss recreational boat migrations with respect to hull-borne invasive species.

\section{Commercial Vessels}

The IMO deals with shipping in international trade, including such aspects as maritime safety, navigation efficiency and prevention and control of marine pollution from ships. The IMO, together with the Global Environment Facility (GEF) and the United Nations Development Programme
(UNDP), established the Global Ballast Water Management Programme to address the introduction of invasive marine species into new environments through ballast water, hull fouling and other vectors. ${ }^{34}$

According to the Ad Hoc Technical Expert Group on Gaps and Inconsistencies in the International Regulatory Framework in relation to Invasive Alien Species, "Hull fouling associated with international shipping is considered an equal or greater risk than disposal of ballast waters, but is not yet regulated. The Parties to the Convention on Biological Diversity have already called on IMO to develop mechanisms to minimize hull-fouling as a matter of urgency. In addition, the need to control or minimize hull fouling as a pathway is also highlighted (in) the Conference of the Parties to the Convention on Biological Diversity. Policies for the prevention and/or management of invasive alien species are also being developed under some of the regional seas agreements."35

\section{Military Vessels}

Movements of military vessels may create new pathways for species introduction.

Invasive species have been well documented on hulls of military vessels in Hawaii.

Analysis of benthic organisms and fishes of Pearl Harbor sampled in 1996 suggests two periods of relatively high introduction rates corresponding to wartime periods. Most of the introduced species with known geographic origins have distributions extending to the Indo-West Pacific. However several species are known from the Red Sea and the Caribbean Sea. ${ }^{36}$

The United States Department of Defense conducted a project to develop a better understanding of the role that their operations may play in AIS introductions. 
Due to funding and ship operations constraints, the project focused solely on ballast water introductions rather than both ballast and hull fouling. ${ }^{37}$

Steps taken by commercial and military vessels to eliminate hull fouling are not completely effective and organisms are still being transported by this means. ${ }^{38}$

\section{Ship-Breaking Issues}

Environmental concerns of ship-breaking include the transport of AIS inside vessels. For example, derelict ships transported from San Francisco Bay to Oregon to be broken down may carry AIS. Stephen Phillips of the Pacific States Marine Fisheries Commission recommends a ballast water exchange and hull cleaning for these vessels before they arrive in Oregon. ${ }^{39}$ This issue should be considered when managing AIS transport.

\section{How Invasions Proceed}

Fouling organisms can become invasive species when transported to new oceanic regions, which lack parasites, predators and diseases that were present in their point of origin. They may become overabundant and harm the environment and the economy by displacing native species and damaging structures.

Widespread trade between the Atlantic and Pacific has exacerbated problems created by hull transport of invasive species. Although hull fouling has significantly decreased as a result of increased use of steel hulls and antifouling hull coatings, ocean going ships and boats still carry large quantities of invasive species on their hulls. The length of time spent in a port can also affect invasive potential. Longer stays increase opportunities for organisms to colonize habitats at the destination, to colonize other vessels, or to disperse from them during and after transport to another region. ${ }^{40}$

Presence of certain species and heavy fouling on vessel hulls do not necessarily pose a significant biosecurity risk. The risk also depends on: whether invasive species are present on the hull; their potential for establishment; whether or not the invasive species are already present in that location; and the extent of potential negative impacts. The highest biosecurity risks posed by visiting vessels are those carrying AIS. ${ }^{41}$

\section{Elements for Assessing Invasive Potential}

A variety of factors may determine whether AIS will thrive in their new environment. For example, the level of biodiversity, water temperature and weather, salinity, port or ocean characteristics, vessel characteristics, degree of hull maintenance, alterations in donor or recipient regions, species-specific traits, and activities associated with military conflicts are all examples of factors that may influence survival of a non-indigenous species in the recipient region. ${ }^{42} 4344454647$

James Carlton has written that humaninduced changes in an environment have made it easier for non-indigenous species to invade a habitat. Overfishing, use of chemicals in the ocean and changes in nutrient levels and climate can all have adverse effects on native species that make it easier for non-native species to invade an area. ${ }^{48}$ A recent study in San Francisco Bay found that the diversity of native species declined when copper contamination increased, whereas the diversity of nonindigenous species did not. This suggests that copper pollution may make an ecosystem more vulnerable to invasion. ${ }^{49}$ 


\section{Biodiversity}

Scientists disagree on the causal relationship of biodiversity and bioinvasions. Some scientists have argued that low levels of biodiversity can increase the likelihood of exotic marine species invasions. However, other scientists and organizations suggest that bioinvasions may cause reductions in biological diversity. ${ }^{50} 51$ Biodiversity is discussed further in Section II.

\section{Water Temperature and Weather}

Water temperature can affect the survival of AIS. Invasive success and impact depend not only on the invasive species, but also on the invaded habitat and the community that is already established. Temperature may affect invaders and the susceptibility of the established community to an invasion. ${ }^{53}$

A change in water temperature can influence the marine food web by killing native species that provide food for other native species. The loss of native species creates opportunities for alien species to become established. The breeding cycle of certain organisms can also be altered by a change in water temperature.

The warming trend seen on the West Coast of the United States may have promoted the spread of invasive species from San Francisco Bay to Oregon, Washington, and even Canada. For example, Styela clava, a sea squirt introduced to San Francisco Bay via hull fouling, was subsequently seen north of California. Similarly, Sphaeroma quoyanum, a boring isopod from New Zealand, was found in San Francisco Bay in the 1890s, Humboldt Bay in the 1930s, and finally in Oregon in 1995. ${ }^{54}$ Increasingly warmer water temperatures may have allowed these invaders to survive.
According to Dr. Bob Whitlatch of the University of Connecticut, over the past 23 years the annual ocean surface temperature has increased in Long Island Sound with the most pronounced increase in winter water temperature. Invasive species of ascidians (sea squirts, tunicates) became more populous than natives during years with warmer winters and four introduced species have become established. Over time, the combination of greater abundance of invasive species and warmer winter water temperature may make it easier for introduced species, particularly those from warmer climates, to become established and spread. $^{55}$

Minchin and Gollasch also state that the temperature within a port may give insight into whether an invasive species will thrive. For example, AIS are more likely to spawn in areas, such as coves, where water temperature can fluctuate dramatically throughout the day. ${ }^{56}$ Although unusual rainy seasons, such as the Pacific El Niño, may aid in reducing invasive species populations, the associated warm weather can increase their numbers. ${ }^{57}$ An increase in rainwater may reduce invasive species by reducing salinity in coastal areas. ${ }^{5} 59$

Similarly, weather patterns in the recipient region can also determine whether an exotic species will become an invasive pest. ${ }^{60}$ If a species is transported to an area with similar weather patterns, it may adapt more easily to the new environment. For instance, a species from a warm, donor region is more likely to thrive if it arrives in the recipient region during the warm months.

\section{Salinity}

Scientists disagree on the importance of salinity in an area's susceptibility to invasions. For instance, a California survey 
found no correlation between salinity level and quantity of exotic species. ${ }^{61}$ However, a review of invasions of North American coastal marine communities found that considerably more invasions had occurred in waters with higher salinity than in those with lower salinity. $^{62}$

\section{Port, Marina and Ocean Characteristics}

Alterations in either the donor or the recipient region can increase the likelihood that non-indigenous species will prosper. If the environment of the recipient region changes, it may disrupt the lives of indigenous species and give an advantage to non-native species. ${ }^{63}$ For example, deteriorating marine conditions in the Black Sea may be responsible for the growth of the invasive Atlantic ctenophore (comb jelly) Mnemiopsis leidyi. According to Dr. David Secord, "the biological effects of pesticide runoff, salinity changes, eutrophication, and overfishing might have synergistically created conditions favoring the success of M. leidyi." ${ }^{64}$ Other research has found that some invasive, fouling species are more resistant to copper than are native species, ${ }^{65}$ 6667 which suggests that antifouling paints may exacerbate invasions in harbor ecosystems.

Changes that increase populations of organisms in a donor region may increase the likelihood that they will be transported. However, scientists disagree on how humaninduced changes affect bioinvasions. For example, some scientists believe that extensive efforts to reduce pollution may improve water quality to the point that certain species may expand their range to cleaner waters. Alternatively, increased pollution may increase local populations. For example, the increase of the baydwelling clam Theora lubrica in polluted environments in the Inland Sea of Japan in
1978 and 1979 correlated with its appearance in San Francisco Bay, which received much ballast water from the Inland Sea. ${ }^{68}$

Human-induced changes to a recipient region can also benefit non-native species. For example the construction of new breakwaters and groins will provide colonization opportunities for sedentary and encrusting species, such as mussels and barnacles. Dredging and other changes to drainage basins may significantly alter hydrographic regimes in ports. These types of changes may create opportunities for nonindigenous species to establish while native species are trying to adjust to changes in their environment. 69

Port expansions may also increase invasive species introductions by increasing the number of vessels coming directly from foreign ports. ${ }^{70}$

The frequency and type of vectors arriving in a port also influence the likelihood that an invasive species will survive. The high level of invasions in San Francisco Bay may be due to the many vectors that have introduced invasive species, including ship ballast water and hull fouling, aquaculture and seafood imports. $^{71}$

Physical oceanographic characteristics may also influence whether an invasive species will thrive in its recipient region. If the waves are calm, organisms are more likely to attach to a structure and survive. On the other hand, if the currents are strong, it would be more difficult for species to cling to a surface and they may be swept further into the ocean. ${ }^{72}$ Similarly, ports and marinas that are well flushed may be less susceptible to bioinvasions. An exception is barnacles, which tend to foul boat bottoms in open, unconfined oceans. ${ }^{73}$ 
Ports on the West Coast of the United States may be more susceptible to exotic species invasions than the east coast because fewer ports serve vessels on the Pacific coast than on the Atlantic coast. Thus "a relatively limited number of donor sites would perhaps result in repeated inoculations of the same species more frequently to the West Coast than to the East Coast, and this could increase invasion success." ${ }^{\text {,74 }}$ In other words, fewer ports on the West Coast could lead to increased concentration of shipping traffic and increased exposure to the same group of non-indigenous species in each port. The more often that a species is introduced to a given port, the greater the chance that it will become established.

The rate at which AIS are becoming established in ports worldwide has increased dramatically. New estuarine and marine species have become established once every 32 weeks (San Francisco Bay) to 85 weeks in six ports that were studied in the United States, Australia and New Zealand. The rate of establishment appears to be increasing. ${ }^{75}$

\section{Vessel Characteristics and Hull Maintenance}

In many marinas throughout the world pleasure craft owners pay divers to scrub fouling off their boats. Although this may prevent or slow fouling accumulation on boats, the organisms that are removed are often released into the water. This activity may aid in the introduction of aquatic invasive species, if the vessel has traveled from a long distance and if its hull is carrying invasive species that have not already become established locally. Furthermore, if fouling is removed in a small boatyard without facilities to treat invasive species, they may be released to the harbor. ${ }^{76}$ However, in-water hull cleaning of pleasure craft that spend most or all of their time in the home marina or harbor likely presents little risk of introducing new, invasive species. Precautions should be taken before and after trips out of the home port, fishing trips and long-distance cruises.

The age of the antifouling coating may also determine whether a new invasive species will survive or not. For instance, ships tend to lack fouling if the period between coating applications is less than 663 days, and if the vessel travels for 9.75 days or more in open waters. ${ }^{77}$ As an antifouling paint ages, its metal content decreases. In other words, if antifouling paints are not reapplied frequently, the antifouling agent leaches out, reducing the coating's effectiveness and potentially increasing the risk of transporting AIS. ${ }^{78}$

Vessel speed can also affect the survival of invasive species. Long-distance travel is becoming easier and faster. This enables more invasive species to survive long enough to reach a new environment. ${ }^{79}$ Indeed, Cordylophora caspia, a hydroid that lives in both freshwater and brackish water, may have been transported successfully because of an increase in ship speeds. ${ }^{80}$

On the other hand, boats that travel at slower speeds are also susceptible to invasions because more species can attach firmly to their hulls. ${ }^{81}$ Furthermore, some nontoxic antifouling coatings are effective only if the vessel travels regularly at 15 knots $^{82}$ to 20 knots. ${ }^{83}{ }^{84}$ Such coatings would be ineffective in preventing attachment of invasive species on hulls of vessels that seldom or never reach or exceed those speeds.

\section{Species Characteristics}

Characteristics specific to certain invasive species may determine whether they will 
survive in the recipient region. For example, gobies prefer to hide or spawn in areas where clefts are plentiful; this preference makes them a likely candidate for transfer via ballast intake grates on ships’ hulls. Dock pilings and bottom debris in ports and marinas offer habitat for invasive species. The ability to survive without light also increases the likelihood that a non-native species in a dark, ballast-water compartment will reach the recipient region. ${ }^{85}$

\section{Wars}

Armed conflicts have also spread invasive species throughout the world. Several such introductions occurred during World War II. For example, the Australian barnacle (Elminius modestus), was transported to England, and similarly, the California isopod (Paracerceis sculpta) and the saltwater fly (Ephydra gracilis) were introduced to Hawaiian waters. Both $S$. walkeri and $M$. sallei are fouling organisms. ${ }^{86}$ The slipper limpet (Crepidula fornicate) from Great Britain was transported to the Normandy Coast of France during the Allied invasion. ${ }^{87}$

Palaemon macrodactylus, a shrimp from Korea and Japan, was transported to San Francisco after the Korean War. Sphaeroma walkeri, an isopod from the western and southwestern Pacific Ocean, was introduced to San Diego after the Vietnam War. The black-striped mussel (Mytilopsis sallei) was transported to Hong Kong by Vietnamese boats carrying refugees.

\section{Boats Involved in Long Distance or International Fishing Expeditions}

Recreational boats and commercial fishing vessels traveling long distances to fish are more likely to transport invasive species to and from their destinations than boats that travel shorter distances. According to the Northeast Midwest Institute, recreational boats are the primary cause of AIS transport in Maine. A local survey found that invasive weeds were attached to the hulls of 1,200 recreational boats. ${ }^{88}$

Pleasure craft that are involved in international boat races or come into contact with boats that have traveled long distances are more likely to transport invasive species, from other regions than boats that are involved in short-distance races.

Recreational boats that travel only in salt water or are kept in saltwater marinas are likely to have fouling growth on their hulls. Boat hulls may carry AIS, even if they have antifouling paint and are cleaned regularly. Invasive species transported to ports on hulls of commercial vessels may transfer to recreational boats in nearby marinas. ${ }^{89}$ They may then be carried along the coast when boats visit other harbors.

Removing fouling growth before taking a long-distance trip, visiting an island or attending an event with boats from other areas can help to prevent transport of potential invaders. Similarly, fouling growth should be removed before returning from a long distance trip or event attended by boats from other areas. In some areas, boat are hauled out of the water and cleaned with freshwater to remove foreign species. ${ }^{90}$

Boats, whose owners do not reapply antifouling paint when its toxicant is exhausted or do not clean the boat after returning from long distance travel, are much more susceptible to colonization by AIS. ${ }^{91}$ A New Zealand study found that the age of antifouling paint was the most important predictor of fouling growth; yachts with the least amount of fouling growth had been painted approximately 10 
months before the study. ${ }^{92}$ Similarly, an Australian study found that vessels with old antifouling coatings had the most fouling growth. In this study, four domestic and four international vessels were examined for fouling on their hulls. Two of the domestic vessels had aged antifouling paint and were covered with algae and other fouling growth. $^{93}$

More information about preventing invasive species introductions on boat hulls is presented in Sections VIII and IX of this report.

\section{Collaborations to Prevent Aquatic Bioinvasions}

Canada, Mexico and the United States all consider invasive species a substantial threat to their environments and economies. The North American Agreement on Environmental Cooperation (NAAEC), an environmental side accord to the North American Free Trade Agreement (NAFTA), established the Commission for Environmental Cooperation (CEC). Part of its role is to protect marine and aquatic ecosystems from the effects of AIS. ${ }^{94}$

Virtually all the ports and bays of North America have at least some marine species that have arrived from other parts of the globe. Shipping is the sole vector for approximately half of AIS found on North American coasts: $60 \%$ on the East Coast, $48 \%$ on the West Coast and $64 \%$ on the Gulf Coast. $^{95}$

Representing all states and provinces west of the 100th Meridian as well as Guam, Hawaii and Alaska, the Western Regional Panel (WRP) on Aquatic Nuisance Species was formed in 1997 to help limit the introduction, spread and impacts of aquatic nuisance species into the Western Region of
North America. The WRP is comprised of Western Region representatives from Federal, State, and local agencies and from private environmental and commercial interests. The goal of the WRP is to protect western aquatic resources by preventing the introduction and spread of exotic nuisance species into western marine and freshwater systems though the coordinated management and research activities of state, tribal, federal, commercial, environmental and research entities and of other regional panels. ${ }^{96}$

Representing California, Oregon, Washington, Idaho and Alaska, the Pacific States Marine Fisheries Commission (PSMFC) is dedicated to resolving fishery issues. The objective of the PSMFC's Aquatic Nuisance Species program is to prevent AIS from harming important commercial and recreational fisheries and the ecosystems upon which these activities depend. $^{97}$

\section{References}

\footnotetext{
${ }^{1}$ McNeely, J.A., H.A. Mooney, L.E. Neville, P. Schei, and J.K. Waage (eds). 2001. A global strategy on invasive alien species. IUCN Gland, Switzerland, and Cambridge, UK, in collaboration with the Global Invasive Species Programme.

${ }^{2}$ Chilton, C. 1911 . Note on the dispersal of marine Crustacea by means of ships. Transactions of the New Zealand Institute 43: 131-133.

${ }^{3}$ Pyefinch, K.A. 1950. Notes on the ecology of ship fouling organisms. Journal of Animal Ecology 19: 29-35.

${ }^{4}$ Allen, F.E. 1953. Distribution of marine invertebrates by ships. Australian Journal of Marine and Freshwater Research 4: 307-316.

${ }^{5}$ Skerman, T.M. 1960. Ship fouling in New Zealand waters: a survey of marine fouling organisms from vessels of the coastal and overseas trades. New Zealand Journal of Science 3: 620-648.

${ }^{6}$ Carlton, J.T. 1989. Man's role in changing the face of the ocean: biological invasions in the Pacific Ocean. Bulletin of Marine Science 41: 452-465.

${ }^{7}$ Carlton, J.T. 1985. Transoceanic and interoceanic dispersal of coastal marine organisms: the biology of
} 
ballast water. Oceanography and Marine Biology Annual Review 23: 313-371.

${ }^{8}$ Cohen, A.N. and J.T. Carlton. 1995. Nonindigenous species in a United States Estuary: A case study of the biological invasions of the San Francisco Bay and Delta. Report of the United States Fish and Wildlife Service, Washington DC and the National Sea Grant College Program Connecticut Sea Grant. CONN-T95-002.

${ }^{9}$ Hewitt, C.L., M.L. Campbell, R.E. Thresher, and R.B. Martin, eds. 1999. Marine biological invasions of Port Philip Bay, Victoria. Technical Report. Commonwealth Scientific and Industrial Research Organization (CSIRO). Hobart, Australia. Call number: 3682

${ }^{10}$ Reise, K, S. Gollasch, and W.J. Wolff. 1999. Introduced marine species of the North Sea coasts. Helgolander Meeresunters 52: 219-234.

${ }^{11}$ Ruiz, G.M., P.W. Fofonoff, J.T. Carlton, M.J. Wonham and A.H. Hines. 2000. Invasion of coastal marine communities in North America: Apparent patterns, processes, and biases. Annual Review of Ecology and Systematics 31:481-531.

${ }^{12}$ Fofonoff, P.W., G.W. Ruiz, B. Steves, and J.T. Carlton. 2003. In ships or on ships? Mechanisms of transfer and invasion for non-native species to the coasts of North America. In Ruiz, G.M. and J.T. Carlton (eds). Invasive species: vectors and management strategies. Island Press, Washington, DC. pp. 152-182.

${ }^{13}$ Roos, P.J. 1979. Two-stage life cycle of a Cordylophora population in the Netherlands. Hydrobiologia 62: 231-239.

${ }^{14}$ Fofonoff, P.W., G.W. Ruiz, B. Steves, and J.T. Carlton. 2003. In ships or on ships? Mechanisms of transfer and invasion for non-native species to the coasts of North America. Pages 152-182 in Ruiz, G.M. and J.T. Carlton (eds). Invasive species: vectors and management strategies. Island Press, Washington, DC.

${ }^{15}$ Cohen, A. N. and J. T. Carlton. 1998. Accelerating Invasion Rate in a Highly Invaded Estuary. Science 279:555-558.

${ }^{16}$ Wasson, K., C.J. Zabin, L. Bedinger, M.C. Diaz, and J.S. Pearse. 2001. Biological invasions of estuaries without international shipping: the importance of intraregional transport. Biological Conservation 102:143-153.

${ }^{17}$ Carlton, J.T. and J.B. Geller. 1993. Ecological roulette: the global transport and invasion of nonindigenous marine organisms. Science 261: 78-82. ${ }^{18}$ Cohen, A.N. and J.T. Carlton. 1995.

Nonindigenous species in a United States Estuary: A case study of the biological invasions of the San
Francisco Bay and Delta. Report of the United States Fish and Wildlife Service, Washington DC and the National Sea Grant College Program Connecticut Sea Grant. CONN-T-95-002.

${ }^{19}$ United States Coast Guard Office of Operating and Environmental Standards. Ballast Water Management Program. http://www.uscg.mil/hq/g-m/mso/bwm.htm Accessed November 10, 2005.

${ }^{20}$ Carlton, J.T. 1985. Transoceanic and interoceanic dispersal of coastal marine organisms: the biology of ballast water. Oceanography and Marine Biology, an Annual Review 23: 313-371.

${ }^{21}$ United States Environmental Protection Agency. Oceans, Coasts and Estuaries: Invasive Species. http://www.epa.gov/owow/invasive_species/ Accessed November 10, 2005.

${ }^{22}$ Raaymakers, S. 2002. The Ballast Water Problem: Global Ecological, Economic, and Human Health Impacts. Paper Presented at the RECSO/IMO Joint Seminar on Tanker Ballast Water Management \& Technologies. Dubai, UAE 16-18 Dec 2002.

${ }^{23}$ Cranfield, H.J., D.J. Gordon, R.C. Willan, B.C. Marshall, C.N. Battershill, M.P. Francis, W.A.

Nelson, C.J. Glasby, and G.B. Read. 1998. Adventive marine species in New Zealand. National Institute of Water and Atmospheric Research, Wellington, New Zealand. Technical Report \#34. 48pp.

${ }^{24}$ Thresher, R.E., C.L. Hewitt, and M.L Campbell. 1999. Synthesis: Introduced and cryptogenic species in Port Philip Bay. In: Hewitt, C.L. M.L. Campbell, R.E. Thresher, R.B. Martin (eds). Marine Biological Invasions of Port Philip Bay, Victoria.

Commonwealth Scientific and Industrial Research Organization (CSIRO). Hobart, Australia. Technical Report \#20. pp.283-295.

${ }^{25}$ Hewitt, C.L. 2002. The distribution and biodiversity of tropical Australian marine bioinvasions. Pacific Science 56(2): 213-222. ${ }^{26}$ Gollasch, S. 2002. The Importance of Ship Hull Fouling as a Vector of Species Introductions into the North Sea. Biofouling 18(2): 105-121.

${ }^{27}$ Coutts, A.D.M., K.M. Moore, and C.L. Hewitt. 2003. Ships' sea chests: an overlooked transfer mechanism for non-indigenous species? Marine Pollution Bulletin 46: 1504-1515.

${ }^{28}$ Godwin, L.S., L.G. Eldgredge, and K. Gautm. 2004. The Assessment of Hull Fouling as a Mechanism for the Introduction and Dispersal of Marine Alien Species in the Main Hawaiian Islands. Bishop Museum Technical Report No. 28.

${ }^{29}$ Coutts, A.D.M. 1999. Hull fouling as a modern vector for marine biological invasions: investigation of merchant vessels visiting northern Tasmania. M.S. Thesis. Faculty of Fisheries and Marine Environment, Australian Maritime College. 
${ }^{30}$ Godwin, L.S. 2003. Hull fouling of maritime vessels as a pathway for marine species invasion to the Hawaiian Islands. Biofouling 19: 123-131.

${ }^{31}$ Wasson, K., C.J. Zabin, L. Bedinger, M.C. Diaz, and J.S. Pearse. 2001. Biological invasions of estuaries without international shipping: the importance of intraregional transport. Biological Conservation 102:143-153.

${ }^{32}$ Cohen, A.N. and J.T. Carlton. 1995.

Nonindigenous species in a United States Estuary: A case study of the biological invasions of the San Francisco Bay and Delta. Report of the United States Fish and Wildlife Service, Washington DC and the National Sea Grant College Program Connecticut Sea Grant. CONN-T-95-002.

${ }^{33}$ Wasson, K., C.J. Zabin, L. Bedinger, M.C. Diaz, and J.S. Pearse. 2001. Biological invasions of estuaries without international shipping: the importance of intraregional transport. Biological Conservation 102:143-153.

${ }^{34}$ Global Ballast Water Management Programme. http://globallast.imo.org/index.asp Accessed October 28, 2005.

${ }^{35}$ Convention on Biological Diversity. 2005. Ad Hoc Technical Expert Group on Gaps and Inconsistencies in the International Regulatory Framework in Relation to Invasive Alien Species. UNEP/CBD/AHTEG/IAS/1/2. Auckland, New Zealand, May 16-20, 2005.

${ }^{36}$ Coles, S.L., R.C. DeFelice, L.G. Eldredge, and J.T. Carlton. 1999. Historical and recent introductions of non-indigenous marine species into Pearl Harbor, Oahu, Hawaiian Islands. Marine Biology 135(1):147158.

${ }^{37}$ Holm, E. 2005. Naval Surface Warfare Center, Carderock Division. Personal Communication, July 20, 2005.

${ }^{38}$ Godwin, L.S. 2003. Hull fouling of maritime vessels as a pathway for marine species invasion to the Hawaiian Islands. Biofouling 19: 123-131. ${ }^{39}$ Gallob, J. 2005. Toxic Trade News. "Shipbreaking issues include invasive species, chemicals.” December 7, 2005.

http://www.ban.org/ban_news/051207_shipbreaking. html Accessed January 30, 2006.

${ }^{40}$ Godwin, L.S., L.G. Eldgredge, and K. Gaut. 2004. The Assessment of Hull Fouling as a Mechanism for the Introduction and Dispersal of Marine Alien Species in the Main Hawaiian Islands. Bishop Museum Technical Report No. 28.

${ }^{41}$ Coutts, A.D.M., and M.D. Taylor. 2004. A preliminary investigation of biosecurity risks associated with biofouling on merchant vessels in New Zealand. New Zealand Journal of Marine and Freshwater Research 38:215-229.
${ }^{42}$ Hewitt, C. L., R. B. Martin. 1996. Port Surveys for Introduced Marine Species-Background Considerations and Sampling Protocols. Centre for Research on Introduced Marine Pests. Technical Report Number 4.

${ }^{43}$ Gollasch, S. Z. 2002. The Importance of Ship Hull Fouling As a Vector of Species Introduction Into the North Sea. Biofouling 18.

${ }^{44}$ Wonham, M.J., J.T. Carlton, G.M. Ruiz, L.D. Smith. 2000. Fish and Ships: Relating Dispersal frequency to Success in Biological Invasions. Marine Biology 136:1111-1121.

${ }^{45}$ Baskin Y. 1998. Winners and Losers in a Changing World: Global Changes may Promote Invasions and Alter the Fate of Invasive Species. Bioscience 48(10).

${ }^{46}$ Carlton, J. T. 1996. Pattern, Process, and

Prediction in Marine Invasion Ecology. Biological Conservation 78: 97-106.

${ }^{47}$ Stachowicz, J. J., R. B. Whitlach, R. W. Osman. 1999. Species Diversity and Invasion Resistance in a Marine Ecosystem. Science Magazine 286: 15771579.

48 Carlton, J. T. 2000. "Global Change and

Biological Invasions in the Oceans.” In

Mooney, H.A. and R.J. Hobbs (eds.) Invasive Species in a Changing World. Island Press: Washington DC. pp. 31-53.

${ }^{49}$ Crooks, Jeff. 2005. Oral commentary. Vessel Fouling Technical Advisory Group, October 13, 2005: Meeting Summary. California State Lands Commission, Sacramento, CA.

${ }^{50}$ United States Environmental Protection Agency. Invasive Species.

http://www.epa.gov/owow/invasive_species/

Accessed September 12005.

${ }^{51}$ Mooney, H. A. and E. E. Cleland. 2001. The

Evolutionary Impact of Invasive Species.

Proceedings of the National Academy of Sciences of the United States of America 98(10).

${ }^{52}$ Vitousek, P. M., C.M. D’Antonio, L.L. Loope, M. Rejmanek, and R. Westbrooks. 1997. Introduced Species: A Significant Component of Human-Caused Global Change. New Zealand Journal of Ecology 21 (1): 1-16.

53 Netherlands Organization for Scientific Research. Secretariat: NIOO Centre for Estuarine and Marin Ecology - CEME. Project: Impact of climate on biological invasions: an experimental approach. Project Leader N.J.M. Gremmen. Project Period: 1/2003-12/2005.

${ }^{54}$ Baskin, Y. 1998. Winners and Losers in a Changing World: Global Changes may Promote Invasions and Alter the Fate of Invasive Species. Bioscience 48(10). 
${ }^{55}$ Wasson, K., D. Lohrer, M.Crawford, and S. Rumrill. 2002. Non-native species in our nation's estuaries. A Framework for an invasion monitoring program. Technical Report Series 2002: 1. Appendix 1: Recommendations from invasion biologists. Bob Whitlatch, University of Connecticut.

${ }^{56}$ Minchin, D. and S. Gollasch. 2003. Fouling and Ships' Hulls: How Changing Circumstances and Spawning Events may Result in the Spread of Exotic Species. Biofouling 19 (Supplement): 111-122.

${ }^{57}$ Lambert, C.C. and G. Lambert. 1998. Nonindigenous Ascidians in Southern California Harbors and Marinas. Marine Biology 130: pp. 675-688.

${ }^{58}$ Thiel, R., A. Sepulveda, R. Kafemann, W. Nellen. 1995. Environmental Factors as Forces Structuring the Fish Community of the Elbe Estuary. Journal of Fish Biology 46 (1): 47-69.

${ }^{59}$ Power, M. and M.J. Attrill. 2002. Factors Affecting Long-term Trends in the Estuarine Abundance of Pogge (Agonus cataphractus). Estuarine, Coastal and Shelf Science 54: 941-949.

${ }^{60}$ McNeely, J.A., H.A. Mooney, L.E. Neville, P. Schei, and J.K. Waage (eds.). 2001. A Global Strategy on Invasive Alien Species. IUCN Gland, Switzerland, and Cambridge, UK. $x+50$ pp.

${ }^{61}$ Cohen, A.N., L H. Harris, B.L. Bingham, J.T. Carlton, J.W. Chapman, C.C. Lambert, G. Lambert, J.C. Ljubenkov, S.N. Murray, L.C. Rao, K.Reardon, E. Schwindt. 2002. Project Report for the Southern California Exotics Expedition 2000-A Rapid Assessment Survey of Exotic Species in Sheltered Coastal Waters. For the California Department of Fish and Game, State Water Resources Control Board of California, and San Francisco National Fish and Wildlife Foundation.

${ }^{62}$ Ruiz, G.M., P.W. Fofonoff, J.T. Carlton, M. J. Wonham, A.H. Hines. 2000. Invasion of Coastal Marine Communities in North America: Apparent Patterns, Processes, and Biases. Annual Review of Ecological Systems 31:481-531.

63 Carlton, J.T. 1996. Pattern, Process, and Prediction in Marine Invasion Ecology. Biological Conservation 78: 97-106.

${ }^{64}$ Secord, D. 2003. Biological Control of Marine Invasive Species: Cautionary Tales and Land-based Lessons. Biological Invasions 5: 117-131.

${ }^{65}$ Hall, A. 1981. Copper accumulation in copper tolerant and non-tolerant populations of the marine fouling alga, Ectocarpus siliculosus (Dillwyn) Lyngbye. Botanic Marina 24:223-228.

${ }^{66}$ Russell, G. and O.P. Morris. 1973. Ship fouling as an evolutionary process. Proceedings of the $3^{\text {rd }}$ International Congress of Marine Corrosion and Fouling: 719-730. Washington, DC, 1972.
${ }^{67}$ Crooks, J. 2005. Oral commentary. Vessel Fouling Technical Advisory Group, October 13, 2005: Meeting Summary. California State Lands Commission, Sacramento, CA.

${ }^{68}$ Carlton, J. T. 1996. Pattern, Process, and Prediction in Marine Invasion Ecology. Biological Conservation 78, 97-106.

${ }^{69}$ Hewitt, C.L., R.B. Martin.1996.Port Surveys for Introduced Marine Species - Background Considerations and Sampling Protocols. Centre for Research on Introduced Marine Pests. Technical Report Number 4.

${ }^{70}$ Earth Justice. 2001. "Environmental Groups Sue to Prevent Invasive Species Infestations in the San Francisco Bay and Delta." http://www.earthjustice.org/news/display.html?ID=5 0 Accessed November 10, 2005.

${ }^{71}$ Cohen, A.N., J.T. Carlton. 1998. Accelerating Invasion Rate in a Highly Invaded Estuary. Science 279: 555-558.

${ }^{72}$ New Zealand Ministry of Fisheries. 2002. Development of a Risk Profile for New Exotic Marine Organisms that may Arrive in New Zealand Via Ship Ballast Water and Hull Fouling. Copyrighted property of Sinclair Knight Merz.

${ }^{73}$ Floerl, O., G.J. Inglis. 2003. Boat Harbour Design Can Exacerbate Hull Fouling. Austral Ecology 28: 116-127.

${ }^{74}$ Ruiz, G.M., P.W. Fofonoff, J.T. Carlton, M.J. Wonhan, A. H. Hines. 2000. Invasion of Coastal Marine Communities in North America: Apparent Patterns, Processes, and Biases. Annual Review of Ecological Systems 31: 481-531.

${ }^{75}$ Bax, N., A. Williamson, M. Aguero, E. Gonzalez, and W. Geeves. 2003. Marine invasive alien species: a threat to global biodiversity. Marine Policy 27(4): 313-323.

${ }^{76}$ Minchin, D. and S. Gollasch. 2003. Fouling and Ships' Hulls: how Changing Circumstances and Spawning Events may Result in the Spread of Exotic Species. Biofouling 19 (Supplement): 111-122.

${ }^{77}$ Coutts, A. 2005. Oral commentary. Vessel Fouling Technical Advisory Group, August 3, 2005: Meeting Summary. California State Lands Commission, Sacramento, CA.

${ }^{78}$ Johnson, L.T. and J.A. Miller. 2003. Making Dollars and Sense of Nontoxic Antifouling Strategies for Boats. California Sea Grant College Program Report No. T-052.

${ }^{79}$ Ruiz, G.M., P.W. Fofonoff, J.T. Carlton, M.J. Wonham, A.H. Hines. 2000. Invasion of Coastal Marine Communities in North America: Apparent Patterns, Processes, and Biases. Annual Review of Ecological Systems 31:481-531. 
${ }^{80}$ Carlton, J.T. 1996. Pattern, Process, and Prediction in Marine Invasion Ecology. Biological Conservation 78:97-106.

${ }^{81}$ Minchin, D. and S. Gollasch. 2003. Fouling and Ships' Hulls: How Changing Circumstances and Spawning Events may Result in the Spread of Exotic Species. Biofouling 19 (Supplement): 111-122.

${ }^{82}$ UK Health and Safety Executive. Safe Use of TinFree, Marine Anti-Fouling Coating. http://www.hse.gov.uk/fod/infodocs/730_15id.pdf Accessed August 4, 2005.

${ }^{83}$ Swain, G. 2000. University research on antifouling strategies and environmental considerations. Presentation to Alternative Antifouling Strategies Conference, September 21-22, 2000. San Diego, CA. ${ }^{84}$ Swain, G., C. Kavanagh, B. Kovach, and R. Quinn. 2001. The antifouling performance of non-toxic silicone fouling release coatings. In: Proceedings of Symposium on Prevention of Pollution from Ships and Shipyards. April 4-5, 2001. Miami, FL.

${ }^{85}$ Wonham, M.J., J.T. Carlton, G.M. Ruiz, L.D. Smith. 2000. Fish and ships: Relating Dispersal frequency to Success in Biological Invasions. Marine Biology 136:1111-1121.

${ }^{86}$ Carlton, J.T. 1996. Pattern, Process, and Prediction in Marine Invasion Ecology. Biological

Conservation 78: 97-106.

${ }^{87}$ Minchin, D. and S. Gollasch. 2003. Fouling and Ships' Hulls: How Changing Circumstances and Spawning Events may Result in the Spread of Exotic Species. Biofouling 19 (Supplement): 111-122.

${ }^{88}$ Northeast Midwest Institute. Aquatic Invasive Species in Maine: How the National Aquatic Invasive Species Act of 2003 Can Help.

http://www.nemw.org/state\%20and\%20regional\%20 NAISA\%2003\%20fact\%20sheets.pdf Accessed January 30, 2006.

${ }^{89}$ Minchin, D. and S. Gollasch. 2003. Fouling and Ships' Hulls: How Changing Circumstances and Spawning Events May Result in the Spread of Exotic Species. Biofouling 19 (Supplement): 111-122.

${ }^{90}$ Manitoba Water Stewardship. Fish and Habitat: Aquatic Invasive Species.

http://www.gov.mb.ca/waterstewardship/ais/ Accessed September 12005.

${ }^{91}$ Johnson, L.T. and J.A. Miller. 2003. Making Dollars and Sense of Nontoxic Antifouling Strategies for Boats. California Sea Grant College Program Report No. T-052.

${ }^{92}$ Floerl, O., G. J. Inglis, B. J. Hayden. 2005. A RiskBased Predictive Tool to Prevent Accidental Introductions of Nonindigenous Marine Species. Environmental Management 35(6): 765-778.

${ }^{93}$ Rainer, S.F. 1995. Potential for the Introduction and Translocation of Exotic Species By Hull Fouling:
A Preliminary Assessment. CSIRO, Centre for Research on Introduced Marine Pests Technical Report Number 1.

${ }^{94}$ North American Commission for Environmental Cooperation. 2002. North American Agenda for Action: 2003-2005. Conservation of Biodiversity. Closing the Pathways of Aquatic Invasive Species across North America. http://www.cec.org/files/PDF/BIODIVERSITY/22503-05_en.pdf Accessed October 28, 2005.

${ }^{95}$ Ruiz, G.M., P.W. Fofonoff, J.T. Carlton, M.J. Wonham and A.H. Hines. 2000. Invasion of coastal marine communities in North America: Apparent patterns, processes, and biases. Annual Review of Ecology and Systematics 31:481-531.

${ }^{96}$ Western Regional Panel on Aquatic Nuisance Species. 2005. http://www.fws.gov/answest/ Accessed January 25, 2006.

${ }^{97}$ Phillips, S.H. and M.D. Sytsma. 2003. Interjurisdictional Responses to Aquatic Nuisance Species in the Pacific Northwest, Pacific States Marine Fisheries Commission. Proceedings of the Third International Conference on Marine Bioinvasions, La Jolla, California, March 16-19, 2003. p. 106. http://sgnis.org/publicat/philsyts.htm Accessed October 28, 2005. 


\section{Risk of Transporting Aquatic Invasive Species on Hulls of Boats Traveling in California and Baja California}

\section{The Risk of Introduction or Spread of AIS by Recreational Boats}

\section{CALIFORNIA}

The California Department of Fish and Game conducted studies in 2002 to develop a list of non-indigenous species occurring in the marine and estuarine waters of California. The studies were stipulated by the Ballast Water Management Act of 1999, Government Code 71211. Samples were collected from the ports of San Diego, Los Angeles/Long Beach, Port Hueneme, Stockton, Sacramento, San Francisco (through a literature review), Humboldt Bay, and numerous smaller harbors and bays along the California coast.

These studies found that all areas of the California coast have experienced some level of invasion by species not native to the state or not native to the area of the coast where they have recently been discovered. The greatest numbers of aquatic invasive species (AIS) occur in the two major commercial ports of San Francisco and Los Angeles/Long Beach because they receive the most ship traffic and are the most exposed to this vector. However, the Sacramento/San Joaquin Delta and the smaller commercial ports at Humboldt Bay, Stockton, Sacramento, Port Hueneme and San Diego also have a significant number of non-indigenous species. ${ }^{1}$

Most research on the study of invasive species introductions by hull transport has focused on commercial shipping. However, little attention has been paid to transport on small-craft hulls such as sail and powerboats. However, researchers have found introductions in harbors where there are no commercial vessels. This has led them to hypothesize that recreational boating plays a significant role. According to Minchin et al., "Such craft vary in design from small open boats, yachts and cruisers to small working vessels. Fouling of biota on hull surfaces, engine components, abstraction ports, tunnels and projections result in varying numbers of non-indigenous species being transported. Some vessels, such as yachts, can range widely and may be capable of transmissions across oceans."2

For example, Elkhorn Slough is an estuary located about $150 \mathrm{~km}$ south of San Francisco Bay at the midpoint of Monterey Bay. The small harbor of Moss Landing at the estuary's mouth serves fishing and recreational boats. Researchers were astonished to discover the largest number of exotic invertebrates recorded for an estuary without international shipping. A total of 56 exotic invertebrate species were found in Elkhorn Slough. Forty-one of these species are known to have been introduced to California by ship fouling, 17 of which are known to have been introduced also by ballast water.

Boat traffic patterns lend strong support to the assumption that commercial fishing and recreational boats have played a significant role in introducing these species to the estuary. Elkhorn Slough has no contact with commercial shipping vessels but there is heavy boat traffic between Moss Landing and San Francisco Bay, where international shipping has introduced 150 invasive species. According to the Elkhorn Slough study, "The 600 or so resident fishing and pleasure boats [at Moss Landing] travel short distances up and down the coast. For instance, many fishing boats from the Monterey Bay region travel annually to the 
San Francisco Bay area to catch herring and, when fishing is poor or weather is bad, often remain there for long periods before returning to Moss Landing. There is also an annual migration of fishing boats along the coast, bringing a temporary influx of boats to Monterey Bay from other regional harbors as far south as Baja California, Mexico, and from as far north as Alaska.”

This suggests that boats that stay in San Francisco Bay for lengthy periods of time have likely brought back invasive species and introduced them to the estuary through the harbor at Moss Landing. Examples of some of the invasive species found in Elkhorn Slough, which are known to occur elsewhere in California, are Mediterranean mussel (Mytilus galloprovincialis), bay barnacle or acorn barnacle (Balanus improvisus), Australasian isopod (Sphaeroma quoyanum), European green crab (Carcinus maenas), sea grapes (Molgula manhattensis) and club tunicate (Styela clava). ${ }^{3}$

According to a study by Lambert and Lambert of non-indigenous ascidians (also called tunicates or sea squirts) in Southern California, recreational boats probably contributed to the rapid dispersal of these organisms along the coast after they were introduced to commercial ports by ships. They state, "Unless major changes occur in the rules governing exchange of ballastwater and the movements of many thousands of pleasure-craft from port-toport, we can expect that non-indigenous ascidians as well as other species will continue to appear at an ever-escalating rate."4

\section{BAJA CALIFORNIA}

In Mexico the issue of AIS is still in its infancy. According to the United Nations
Commission for Environmental

Cooperation, as of 2001 Mexican scientists believed that most invasive species were found in the northern regions of the country, namely in Chihuahua, Baja California and Coahuila. $^{5}$

In 1992, an International Meeting on the Problems of the Knowledge and Conservation of Biodiversity was convened by the President of Mexico. Primary discussion topics included: critical aspects of our present knowledge of biodiversity; current risks to biodiversity; possible consequences of these risks; and appropriate actions to safeguard biodiversity. As a result of this meeting, on March $16^{\text {th }}, 1992$ the President of Mexico created the National Commission for the Knowledge and Use of Biodiversity. ${ }^{6}$ The commission (known as CONABIO) aims to: compile existing information on invasive species for terrestrial and marine environments; obtain species checklists that define priority species in order to finance specific ecological studies; determine the geographic distribution of invasive and target species; and discuss strategies to control and eradicate these species.

According to Veronica Aguilar of CONABIO, there is practically no information regarding AIS in Mexico, much less a list of known invasive species in Baja California. However, she says that the issue of ballast water from ships is beginning to be of interest. Mexico is currently working on public policies concerning the handling of ballast water by navigating ships within Mexican jurisdiction. She also says that most of the potential threats of invasive species exist in California but have not yet arrived in Mexico. ${ }^{7}$ According to Fernando Garcia Pamanes at the Autonomous University of Baja California (UABC) in Ensenada, environmental researchers are 
aware of the issue, but very few articles are published about invasive species and little action has been taken due to fiscal and staffing constraints. ${ }^{8}$

However, macroalgae researchers at the Institute of Oceanographic Research at UABC in Ensenada have published some articles on invasive seaweeds, which they hypothesize may have been introduced to the region by means of recreational hull transport.

One example is the invasive brown alga known as Asian kelp (Undaria pinnatifida). This species was found and recorded for the first time on the Mexican Pacific coast in September 2003 at Todos Santos Island in Baja California. It is believed to be native to Japan, Korea and China and was first discovered in California in spring 2000. By summer 2001 it had colonized areas between Monterey Bay and Santa Catalina Island. ${ }^{9}$ UABC researchers Raul Aguilar-Rosas and Luis Aguilar-Rosas suggest that the presence of Undaria in Baja California is probably related to the intense traffic of commercial vessels, cruise ships, and recreational boats, mostly coming from California, in Ensenada harbor. ${ }^{10}$ Undaria's impacts include nuisance fouling, as well as competition for space and light, which could lead to the exclusion and displacement of native species. ${ }^{11}$ For more information on Undaria pinnatifida and its impacts, see Section VI.

Scientists at the Institute of Oceanographic Research at UABC, port officials in Baja California, and the University of California Sea Grant Extension Program in San Diego are discussing how to share information on AIS, and how to collaborate to find sustainable measures for managing nonindigenous marine organisms.

\section{Where Recreational Boaters Are Traveling in and out of California}

To better evaluate the risk of AIS transport by recreational boats in California, it is important to understand the general scope of boat movement in and out of the state. This information will improve understanding of the potential for species transport, likely locations of introductions, and appropriate use of boat hull cleaning to prevent further introductions. Outside of California, the main concern is boat traffic to and from Baja California because of its close proximity and popularity with California boaters.

California's coast is a major world destination for leisure travel. Ocean recreational activities alone contributed approximately $\$ 42.9$ billion to the State's economy in 2000. ${ }^{12}$ Recreational boating is one important contributor; in 2000, it contributed \$16 billion to California's economy. ${ }^{13}$ In 2004, California had 894,884 registered boats ${ }^{14}$ and in 2002 had about 62,000 marina slips, of which approximately 36,000 , or $58 \%$, were in Southern California. ${ }^{15}$ Because recreational boating is used for leisure travel, it is impossible to track individual voyages and destinations. However, boating events and fishing "hot spots” that attract boaters and sport fishers from different parts of the coast can be identified. Levels of boating traffic related to these activities suggest where higher risks of potential invasive species transport are likely to occur.

\section{Destinations}

California's coastal boating destinations and facilities can be divided into five regions: North Coast, San Francisco Bay, Central Coast, South Coast, and San Diego. Note that the figures include some inland boating 
in the counties included in these coastal regions. Also see the map in Appendix D.

Trip length and frequency influence the likelihood that species will be carried beyond the home region or brought back from a distant region. Table 1 shows the percentage of boaters in each region who took various numbers of trips over 100 miles from home in 2000. In the South Coast region, nearly one-half of boaters took no trips over 100 miles from home. Elsewhere, the majority of boaters took no trips over 100 miles from home. About one-fourth to nearly one-half of boaters in each region took a few (one to five) trips that year. The remaining one-seventh to one-fifth of boaters in each region took occasional to very frequent (six to more than 20) long trips in 2000. This suggests that AIS management procedures and educational programs could be targeted most productively at boaters who take long trips.

Table 1. Percentage of boaters by region who traveled more than 100 miles from home in 2000. ${ }^{16}$

\begin{tabular}{|c|c|c|c|c|c|}
$\begin{array}{c}\# \\
\text { Trips } \\
\mathbf{1 0 0}\end{array}$ & $\begin{array}{c}\text { North } \\
\text { Coast }\end{array}$ & $\begin{array}{c}\text { SF } \\
\text { Bay }\end{array}$ & $\begin{array}{c}\text { Central } \\
\text { Coast }\end{array}$ & $\begin{array}{c}\text { South } \\
\text { Coast }\end{array}$ & $\begin{array}{c}\text { San } \\
\text { Diego }\end{array}$ \\
\hline None & $54.0 \%$ & $52.3 \%$ & $55.3 \%$ & $42.7 \%$ & $55.4 \%$ \\
\hline $1-5$ & $33.1 \%$ & $27.1 \%$ & $27.2 \%$ & $44.8 \%$ & $31.2 \%$ \\
\hline $6-20$ & $9.2 \%$ & $13.3 \%$ & $13.9 \%$ & $7.6 \%$ & $11.3 \%$ \\
\hline$>20$ & $2.9 \%$ & $6.9 \%$ & $3.8 \%$ & $4.9 \%$ & $2.1 \%$ \\
\hline
\end{tabular}

Note: Data in columns do not sum to $100 \%$ as per published source.

1. The North Coast Region consists of four counties: Del Norte, Humboldt, Mendocino, and Sonoma. In 2000, the population of the region was about 712,000 with 34,643 registered boats approximately 1 boat per 21 people. Although this is the highest per capita rate of boat ownership in the state, the majority are used for commercial or fishery purposes and there are few recreational boating facilities. These boaters most often use the Pacific Ocean, Humboldt Bay, and outside waterways leading to San Francisco Bay and Tomales Bay. In 2000, 54.0\% of boaters made no trips of 100 miles from home, $33.1 \%$ made one to five such trips, 9.2\% made six to 20 such trips and 2.9\% made more than 20 trips over 100 miles from home.

2. The San Francisco Bay Region consists of eight counties: Alameda, Contra Costa, Marin, Napa, San Francisco, San Mateo, Santa Clara, and Solano. In 2000, the population of the region was about 6,468,700 with 158,223 registered boats - approximately 1 boat per 41 people. There are a large number of boating facilities in the San Francisco Bay area, accounting for $18 \%$ of the total facilities in the state. Boaters of the region most often use the Pacific Ocean, San Francisco Bay, and the Sacramento-San Joaquin Delta. In 2000, 52.3\% of boaters made no trips of 100 miles from home, $27.1 \%$ made one to five such trips, $13.3 \%$ made six to 20 such trips and $6.9 \%$ made more than 20 trips over 100 miles from home.

3. The Central Coast Region consists of three counties: Santa Cruz, Monterey, and San Luis Obispo. In 2000, the population of the region was about 922,700 with 30,617 registered boats approximately 1 boat per 30 people. Per capita boat ownership is second only to the North Coast Region and there are numerous commercial fishing boats. This region has relatively few recreational boating facilities, accounting for only 3\% of the statewide total. Boaters of the Central Coast 
Region most often use the Pacific Ocean, Morro Bay, and Monterey Bay. In $2000,55.3 \%$ of boaters made no trips of over 100 miles, $27.2 \%$ made one to five such trips, $13.9 \%$ made six to 20 such trips, and 3.8\% made more than 20 such trips.

4. The South Coast Region consists of four counties: Santa Barbara, Ventura, Los Angeles, and Orange. In 2000, the population of the region was about 13,910,900 with 245,380 registered boats - approximately 1 boat per 57 people. Despite the large number of boaters, there are relatively few facilities in the South Coast Region, the large majority of which are privately-owned marinas; this suggests that many boats are kept on trailers. These facilities account for $13 \%$ of the total number of facilities statewide. Boaters of the region most often use the Pacific Ocean, Channel Islands Harbor, Marina Del Rey, Mission Bay, Los Angeles-Long Beach Harbor, Newport Harbor, and Dana Harbor. In 2000, 42.7\% of boaters made no trips of over 100 miles, $44.8 \%$ made one to five such trips, $7.6 \%$ made six to 20 such trips, and $4.9 \%$ made more than 20 such trips.

5. The San Diego Region consists of San Diego County. In 2000, the population of the region was about 2,883,600 with 68,231 registered boats - approximately 1 boat per 42 people. There are about 60 facilities in the San Diego region, accounting for $7 \%$ of the statewide total, the majority of which are privatelyowned marinas. Boaters of the region most often use San Diego Bay, Mission Bay, the Pacific Ocean, and Oceanside Harbor. In 2000, 55.4\% of boaters made no trips of over 100 miles, 31.2\% made one to five such trips, $11.3 \%$ made six to
20 such trips, and $2.1 \%$ made more than 20 such trips. ${ }^{17}$

\section{Races}

Recreational boat races are enjoyable ways to take the boat out for a run; they also cause boats to converge from disparate locations. Short-distance races for local boats are held often all along the coast. These races generally pose a low risk for invasive species transport because the boats generally come from the same harbor and the course is usually within it. Nevertheless, boaters from other parts of the coast may attend such races. Intermediate- and long-distance races pose a relatively higher risk of invasive species transport if boats are not properly cleaned before and after the event.

Examples of short-distance races in California are:

- U.S. Multi Hull Championship held in Long Beach in 2005 on April 6. ${ }^{18}$

- San Diego Bay Championships held in 2005 on July 3. ${ }^{19}$

- Monterey Bay PHRF Championships held in 2005 on July 9. ${ }^{20}$

- Keane Star North American Championship held in Marina Del Rey in 2005 on August 17. ${ }^{21}$

Examples of intermediate-distance races in California are:

- The Channel Islands to Marina Del Rey Race, held in 2005 on June $25 .^{22}$

- The Marina Del Rey to San Diego Race, held in 2005 on July 2. ${ }^{23}$

- The Santa Barbara to King Harbor Race, an 81-mile race, held in 2005 from August 5-6 and consisting of more than 100 entries. $^{24}$

- The Long Beach to Dana Point Race, held on September 4, 2004. ${ }^{25}$ 
Examples of long-distance races originating in California are:

- The Transpac, a race from Los Angeles to Honolulu, held in 2005 from July 1117 and included 72 entries. $^{26}$

- The Biennial West Marine Pacific Cup, a race from San Francisco to Oahu, Hawaii, held in January 2006. ${ }^{27}$

Examples of races and events with participation from multiple places in and outside of California are:

- The Yachting Cup, a race held in San Diego in 2005 from April 29-May 1 and that included 140 boats in 14 classes from all over Southern California. ${ }^{28}$

- The West Coast Morgan Invasion, a gathering of Morgan sailboats from various parts of California held in May at Catalina Island's Isthmus on the weekend following Mother's Day. ${ }^{29}$

- The Sir Thomas Lipton Cup Challenge, a race held in 2005 from May 13-15. Ten yacht clubs from all over Southern California competed in the harbor of the defending champion. ${ }^{30}$

- The 29er Worlds Race, a race held in San Francisco Bay in 2005 from July 210 and included 80-100 boats from 15 countries. $^{31}$

\section{Fishing}

Many recreational boats leave their home ports for sportfishing. Popular fishing spots are located all along the California coast from Point St. George and Crescent City in the north to as far south as San Diego and neighboring waters of Baja California, Mexico. Fishing spots are located from near the shore to as far as 115 miles offshore. Sportfishing is permitted in hundreds of different spots all over California with the exception of certain areas where fishing is prohibited. ${ }^{32}$ Two studies, by Schramm et al. and by Parsons et al., have found that clean water may have a direct correlation with popular fishing destinations. ${ }^{33}$ This suggests that fishermen are attracted to areas with clean water where fish are plentiful and safe for consumption.

According to California Department of Fish and Game’s, "36 Great California Fishing Trips,” barred, redtail, and walleye surfperch are plentiful during March at San Fransico’s beaches from Ocean Beach to Baker and China Beaches. San Francisco Bay can provide plenty of halibut in the month of June at well-known hotspots: Alcatraz, Angel Island, Berkeley Flats, Brooks Island, Paradise, the Sisters, and Treasure Island. In July, one can find king salmon in Shelter Cove and corbina can be found in Santa Monica Bay's southern beaches. ${ }^{35}$ These are a few examples of fishing spots that are popular at specific times of the year. For an overview of sportfishing on the coast of California refer to the map in Appendix A of this report.

Commercial fishing vessels can also play a significant role in the transport of invasive species, especially those that spend months in distant regions of the ocean or follow fishing seasons up and down the coast of California. Commercial fishing trips are difficult to track; available data only includes the amounts of catch brought to shore. Fishing boat traffic patterns are also affected by many factors, such as where the fish are sufficiently abundant, state and federal regulations, and where the buyers of their catch are located.

The following are examples of general movement patterns of types of commercial fisheries in California that may operate beyond their local regions.

- Salmon fisheries tend to stay close to shore but move up and down the coast from as far south as Santa Barbara to 
Northern California and Oregon. The fishing season runs from around May until September with some variation by location.

- Albacore fisheries generally follow similar patterns, except that they can range as far as 100 miles from shore.

- Ground fish trollers also move up and down the coast frequently. Boats based in Oregon tend to travel as far south as Moss Landing; those based in California may travel to Oregon.

- Wet fisheries from Washington and Alaska tend to travel to Southern California in the winter as far south as San Pedro to catch squid. Those based in Southern California tend to fish in Mexican waters from time to time but do not enter Mexican ports.

- Purse seine fishers in Monterey travel north to Oregon and Washington, but may go south for squid.

- Multi-species/multi-gear fisheries tend to take long trips ranging from 20 to 30 days because of their freezer capacities. They may fish for salmon and albacore in the spring and summer and then for shark and swordfish far offshore in the fall. These fisheries move around a great deal.

- Super-seiner fishing vessels based offshore occasionally arrive at Southern California ports and dock for a few days to unload 2 to 3 months' worth of catch from as far away as Samoa and Ecuador.

- Longline fishing vessels from Hawaii, Northern and Southern California can similarly dock for a few days to unload and refuel. They also tend to fish in distant places and deliver to Southern California. $^{36}$

The amount of movement of boats for recreational races and for commercial and recreational fishing beyond local regions in California suggests a high likelihood that invasive species are transported on boat hulls.

\section{Boat traffic between California and Baja California}

Baja California in northwestern Mexico is a very popular destination for recreational boaters from all over California. The main reasons for traveling to Mexico include the good climate, opportunities to rest and relax, the friendly local people, and the ecology. Overall, there are about 2,600 slips in the marinas of the region. ${ }^{37}$ About half the boats that enter Baja California spend part of their stay in a marina. The other half use natural anchorages near marinas, are in the region for very short stays, or simply cruise for most of their trip. The average marina stay is about two weeks, and many boats stay in several marinas over the course of a season. ${ }^{38}$ Many boaters go to Baja California for a race and remain, while others make specific plans to sail to Baja California. Ensenada is the first popular spot upon entering Mexico from the Southern California coast. Many boaters continue to Cabo San Lucas at the tip of the peninsula and beyond to the Gulf of California (also known as the Sea of Cortez). La Paz and Loreto are popular harbors in the Gulf of California with abundant sportfishing opportunities.

Resorts built in these coastal cities reflect their popularity with California tourists. For example, Hotel Coral \& Marina ${ }^{39}$ offers its hospitality to boaters who wish to fish near Ensenada. The One \& Only Palmilla Resort $^{40}$ in Cabo San Lucas attracts wealthy and famous visitors. Generally, any boater who plans to make a serious voyage to Mexico wants to visit the Gulf of California (Sea of Cortez). As a result of its proximity to the Gulf of California, the population of Cabo San Lucas has grown over the last ten 
years from 30,000 to 160,000. Yachting magazine states, "[a] friendly and proud local population enjoys an atmosphere that is part Santa Fe, part Norteño, part Malibu, a mix of touch of gray surfers and golfers, cowboy-booted vaqueros, gold-blinged sportfishermen and New Age yoga devotees." 41

\section{Destinations}

According to a report by the research firm EDAW, Inc., northwestern Mexico contains eight distinct recreational boating areas, six of which are on the Baja California peninsula. Each area has its own character, based on climate, natural features, access and nautical tourism infrastructure. Also see the map in Appendix E of this report.

1. The Ensenada area, from the resorts south of Tijuana through Ensenada to Punta Banda.

2. The Pacific coast of Baja California, from Punta Banda through Bahia de Tortugas, Puerto San Carlos-Bahia Magdalena, to just north of Cabo San Lucas.

3. The Los Cabos area, from Cabo San Lucas through San Jose del Cabo, Bahia de Palmas to Bahia de Los Muertos.

4. The La Paz area, from north of Bahia de los Muertos through La Paz, the Isla Espiritu Santo area to the Punta Evaristo-Isla San Jose area.

\section{The Baja California central coast of} the Sea of Cortez, from Puerto Escondido and the Loreto National Marine Park, Bahia Concepcion, Mulege, Santa Rosalia, to Bahia de los Angeles.
6. The northern Sea of Cortez, from Puertecitos through San Felipe and the adjacent Islas Descansas to Puerto Peñasco in Sonora.

7. The Central Mainland, from Bahia Kino through San Carlos-Guaymas to Topolobampo.

8. The Mazatlan area, from just north of Mazatlan to San Blas. ${ }^{42}$

Ensenada is the first important boating destination upon entering the Pacific coast of Mexico from California. According to the Coordinator of Ecology at the Port of Ensenada, Yoal Aguilar Hernandez, there are a total of 13 marinas with 353 slips in the Ensenada area. Eleven of these are at the Port of Ensenada, one is in La Salina (north of Ensenada), and one is at Marina Coral (next to UABC in Ensenada). ${ }^{43}$ According to Fonatur (Federal Tourism Promotion Fund), in 1998, 80\% of the boats that entered Ensenada were from the United States, particularly California, 13\% were from other foreign countries, and a mere $7 \%$ came from other Baja California domestic ports. Although the amount of boat entry movement from California tends to be balanced during the year due to the proximity of San Diego, a concentrated amount occurs between July and October. ${ }^{44}$

Cabo San Lucas at the southern tip of the peninsula is the second important boating destination after Ensenada. It serves as a gateway to the Gulf of California. According to Fonatur, an average of 1,300 boats arrives in Cabo San Lucas each year. From 1993 to 1996, the port showed a rate of growth near $12 \%$. In Cabo San Lucas, the ratio of arrival origins varies significantly from that of Ensenada because it is a much more attractive destination for boaters from many places. In 1998, approximately 1,435 
boats entered the port, of which $60 \%$ came from the United States, 25\% from the mainland of Mexico, and 15\% from other parts of Baja California. California boaters must travel much farther to reach Cabo San Lucas than they do to reach Ensenada. Therefore, the primary arrival season for Cabo San Lucas is between November and March, when the weather is best for navigation. ${ }^{45}$

La Paz is the third important boating destination in Baja California as it is the traditional destination for boaters wishing to visit the Gulf of California. It typically receives an average of 700 boats each year. Arrivals increased by 2\% from 1993 to 1998. The primary arrival season for La Paz is between November and December. It is busiest between March and May due to organized events. ${ }^{46}$

\section{Races}

Annual races that bring California boaters to Baja California are:

- The Newport to Ensenada Race, a 125mile race from Newport Harbor in the Los Angeles area to Ensenada, held in 2005 from April 22-24 included more than 500 boats in 20 different classes. ${ }^{47}$

- The San Diego to Ensenada International Yacht Race, a race held in 2005 from October 7-8 included 90 yachts in 12 classes. $^{48}$

- The Baja Ha-Ha, a 750-mile race from San Diego to Cabo San Lucas held in 2005 on October 31. Stops are made at Turtle Bay and Bahia Santa Maria before reaching Cabo San Lucas. ${ }^{49}$

Occasional or biennial races that bring California boaters to Baja California are:

- Marina Del Rey to Puerto Vallarta Race, a 1,295-mile race from Marina Del
Rey to Puerto Vallarta on the mainland of Mexico held biannually in February. ${ }^{50}$

- San Diego to Bahia de Manzanillo Race, a 1,288-mile international race from San Diego to Manzanillo on the mainland of Mexico between Puerto Vallarta and Acapulco. The race resumed in February 2004 after a 10 year hiatus. ${ }^{51}$

\section{Fishing}

Both sides of the Baja California peninsula attract much sportfishing. The Gulf of California side is more popular. The region also has a rich history of commercial fishing.

Main fishing destinations for Baja California are as follows:

- Pacific side: Rosarito Beach, Ensenada, Bahia de Todos Santos, Puerto Santo Tomas, Bahia San Quintin, Isla Cedros, Punta Abreojos, Bahia Magdalena, and Cabo San Lucas.

- Gulf side: San Felipe, Bahia Gonzaga, Bahia de los Angeles, Mulege, Loreto, La Paz, the East Cape Area, and San Jose del Cabo. ${ }^{52}$

\section{Mexican Policies}

Mexican policies on tourism and recreational boating also influence boat movement between California and Mexico. According to a 2005 report by the Mexican government, tourism accounts for $8.5 \%$ of Mexico's GDP and 9\% of the country's employment. ${ }^{53}$ Therefore, it is no surprise that Mexico would want to promote tourism. This affects boat movement because certain policies that promote tourism may cause boat traffic to increase significantly and thus increase the threat of invasive species introductions. 
One such policy, known as "La Escalera

Náutica,” which literally means "The

Nautical Staircase,” was proposed in 2001.

The original proposal included building

several new marinas around the Baja

California peninsula and renovating existing

ports and marinas to create a network of 24

stations spaced 100 to 120 miles apart. Each

marina would have a capacity of 25 to 40

boats with nearby restrooms, restaurants, laundromats, bars, gas stations, repair yards, hotels, and commercial centers. ${ }^{54}$ A roadway midway down Baja California would be paved to allow boats to be transported by truck across the peninsula from Santa Rosalillita on the Pacific side to Bahia de los Angeles on the gulf side. Fonatur (Federal Tourism Promotion Fund), which was responsible for the tourist developments of Cancun, Ixtapa, and Huatulco, was assigned to lead the project. ${ }^{55}$ According to John MacCarthy, director of Fonatur, the endeavor would "capture 5.3 million nautical tourists, generate 3 billion dollars and create 60,000 jobs by the year 2015 , thereby benefiting the states of Baja California Sur, Baja California Norte, Sonora, Sinaloa, and Nayarit."56

The project was criticized in 2003 by environmental groups and others, when it was determined that the demand for recreational boat services in Baja California was much lower than originally projected. Fonatur had estimated that about 8,600 boats per year visited the region and projected that by 2014 there would be 61,464 arrivals per year to Baja California and the Gulf of California, of which 14,360 would request a space in a marina. Thus, they had projected an annual growth rate of $17.7 \%$ in visits by United States boats. ${ }^{57}$

EDAW, Inc. (a San Francisco-based company that analyzes economic and environmental impacts of tourism) conducted an independent economic assessment of the market for nautical tourism in Baja California. They found that about 3,000 boats per year visited Baja California in $2001^{58}$ and that demand would increase to about 10,000 boat visits for the year 2014, of which about 5,000 would request a space in a marina. ${ }^{59}$ Thus, they concluded that the average annual rate of increase in number of U.S. boats entering Baja California would only be $7 \% .{ }^{60}$ As a result, EDAW encouraged Fonatur to focus on renovating the five existing marinas at Ensenada, Cabo San Lucas, Guaymas, La Paz, and Mazatlan. ${ }^{61}$

The project was suspended in 2003, pending receipt of proper permits and completion of environmental impact studies. ${ }^{62}$ The project was relaunched on July 1, 2004 and officially renamed Proyecto Mar de Cortés (The Sea of Cortez Project). ${ }^{63}$ It will continue as originally planned but more carefully and over an estimated 25 years instead of 14. Although the project will be completed more slowly, the planned number of nautical stations has increased from 24 to $29 .{ }^{64}$ The project's basic infrastructure has not yet been completed. ${ }^{65}$

According to Fonatur's latest plans, 11 nautical stations will be open by April 2006. ${ }^{66}$ According to Guillermo Acosta, Coordinator of the Program of Integral Tourist Regions of Fonatur, the five stations planned to be launched at the end of 2005 were: La Paz, Puerto Escondido, Santa Rosalia, San Felipe, and Puerto Peñasco. The six stations to be launched in 2006 are: Mazatlan, Bahia de los Angeles, San Blas, Santa Rosalillita, Guaymas, and Topolobampo. He also stated that Santa Rosalillita, Santa Rosalia, Topolobampo, Bahia de los Angeles, and San Blas would receive enough renovation by 2006 to provide basic services of electricity, 
drinking water, sewage system, and residual water treatment plants. ${ }^{67}$

A recent product of the Sea of Cortez Project was the February 2005 opening of Ensenada's new Centro Integral de Servicios (CIS), a streamlined yacht documentation processing service for recreational boaters visiting Mexico. According to the Baja Times newspaper, "In the past, the port clearance procedure was a complicated, time-consuming process because recreational boaters had to comply with requisites from diverse offices and banks scattered throughout Ensenada. But now, with all of the necessary authorities conveniently situated in one building, visitors will be able to save time and receive improved, faster service." ${ }^{68}$ Module 1 of the CIS is dedicated to immigration procedures, module 2 for all harbormaster procedures, module 3 for sport fishing licenses, module 4 for customs, and module 5 for payments towards immigration, sport fishing, and customs procedures. By grouping the offices together in this manner, the CIS hopes to facilitate international tourism more efficiently. $^{69}$

The Sea of Cortez Project will likely increase the risk of AIS transport by boats traveling between California and Baja California.

A more recent Mexican policy, which will no doubt bring more California boaters to Baja California, is the April 19, 2005 policy ending domestic clearing in Mexico. The end of domestic clearance means that a boat owner who arrives in Mexico from California will only need to check in with the port captain and immigration authority at the first port of entry and check out when leaving the country. According to Teresa Grossman of the Mexican Marina Owners Association and owner of Marina San Carlos on the Gulf of California, a typical Mexico cruise of the past would involve checking in and out of each marina and location visited. It is estimated that the new policy will reduce the cost of a cruise in Mexico by hundreds of dollars each season. Boaters will no longer have to spend hours filling out forms and lastly, "cruisers can move about whenever they want, not just when port captain and immigration office hours allowed it.,"70

Letters from California boaters to Latitude 38 magazine express relief that they would not have to spend long hours waiting for clearance when traveling to a new port within Mexico. ${ }^{71}$ Boaters also expressed plans to stay in Mexico longer and visit places that they had never visited before due to burdensome, check-in procedures. ${ }^{72}$ Boaters will be able to travel more freely among boating destinations in Baja California.

Thus, the new clearance policy will encourage more California boaters to visit Mexico, further increasing the risk that aquatic invasive species will be carried between California and Baja California.

\section{References}

\footnotetext{
${ }^{1}$ California Department of Fish and Game. 2002. A Survey of Non-Indigenous Aquatic Species in the Coastal and Estuarine Waters of California. Submitted to the California State Legislature as required by the Ballast Water Management Act of 1999. Prepared and submitted by the Department of Fish and Game, Office of Spill Prevention and Response, December 2002.

${ }^{2}$ Minchin, D., A. Occhipinti, O. Floerl, and D. Savini. 2004. "Small craft as a vector of exotic species.” Presented at the PICES Annual Meeting, Honolulu, Hawaii, October 2004.

${ }^{3}$ Wasson, K., C. Zabin, L. Bedinger, M. Diaz, J. Pearse. 2001. Biological invasions of estuaries without international shipping: the importance of intraregional transport. Biological Conservation 102: 143-153.
} 
${ }^{4}$ Lambert, C. and G. Lambert. 1998. Non-indigenous ascidians in southern California harbors and marinas. Marine Biology 130: 687.

${ }^{5}$ Commission for Environmental Cooperation of North America. 2001. Preventing the Introduction and Spread of Aquatic Invasive Species in North America: Workshop Proceedings, 28-30 March 2001. ${ }^{6}$ CONABIO. 2005. Comision nacional para el conocimiento y uso de la biodiversidad. http://www.conabio.gob.mx/ Accessed July 8, 2005. ${ }^{7}$ Veronica Aguilar, July 18, 2005, CONABIO, personal communication.

${ }^{8}$ Fernando García Pamanes, July 26, 2005. Instituto de Investigaciones Oceanológicas, Universidad Autónoma de Baja California en Ensenada, personal communication.

${ }^{9}$ Aguilar-Rosas, Luis E. and Raul. 2004. The Marine Algae Undaria pinnatifida Invades Baja California Coast. Bight Bulletin (8): 1.

${ }^{10}$ Aguilar-Rosas, Luis E. and Raul. 2004. First Record of Undaria pinnatifida (Harvey) Suringar (Laminariales, Phaeophyta) on the Pacific coast of Mexico. Botanica Marina 47: 255-258.

${ }^{11}$ Burridge, T. and J. Gorski. 1998. The Use of Biocidal Agents as Potential Control Mechanisms for the Exotic Kelp Undaria pinnatifida, Technical Report Number 16. Centre for Research on Introduced Marine Pests. School of Life Sciences, Victoria University of Technology, Melbourne, Australia, CSIRO Marine Research.

${ }^{12}$ Kildow, J. and C. Colgan. 2005. California's Ocean Economy, Report to the Resources Agency, State of California, Prepared by The National Ocean Economics Program, http://resources.ca.gov/press_documents/CA_Ocean_ Econ_Report.pdf Accessed July 2005.

${ }^{13}$ California State University, Sacramento Foundation. 2002. California Boating Facilities Needs Assessment. Volume V: Boating Economic Assessment and Demand Projections. California Department of Boating and Waterways, Sacramento, CA.

${ }^{14}$ State of California Department of Motor Vehicles, "Total Vessel Registrations by County as of 31 Dec. 2004," http://dbw.ca.gov/PDF/VesselReg/Vessel04.pdf Accessed July 2005.

${ }^{15}$ Conlon, Michael. 2002. Northwest Mexico Marina Market Analysis. Prepared for the Packard Foundation, EDAW, i-3.

${ }^{16}$ California Department of Boating and Waterways. 2002. California Boating Facilities Needs Assessment. Volume 2: Regional Boaters and Boating Facilities.
${ }^{17}$ California Department of Boating and Waterways. 2002. California Boating Facilities Needs

Assessment. Volume 2: Regional Boaters and Boating Facilities.

${ }^{18}$ Around the World of Sailing, "U.S. Multi Hull Championships,"

http://www.torresen.com/sailing/content_archives/00 2892.php Accessed August 30, 2005.

${ }^{19}$ The Log. 2005. San Diego Racing. June 24-July 7, B1.

${ }^{20}$ The Log. 2005. Northern California Racing. June 24-July 7, B1.

${ }^{21}$ International Sailing Federation, "Keane Star North American Championship 2005,”

http://www.sailing.org/default.asp?ID=j69Fh5 7C\&f ormat=popup Accessed August 30, 2005.

${ }^{22}$ Santana. 2005. Down the Coast Series. June, 39.

${ }^{23}$ Santana. 2005. Down the Coast Series. June, 39.

${ }^{24}$ Santa Barbara Yacht Club, "Racing 2005," http://www.sbyc.org/Racing.html Accessed: July 2005.

${ }^{25}$ Southwestern Yacht Club Sailing Instructions and Results, "2004 Race Schedule,”

http://www.concentric.net/ Fdross/res1.shtml\#2004 Accessed August 2005.

${ }^{26}$ Latitude 38. 2005. Bay Area Transpac Entries. June, 134.

${ }^{27}$ Pacific Cup Yacht Club: West Marine Pacific Cup 2006. http://www.pacificcup.org/ Accessed January 30, 2006.

${ }^{28}$ San Diego Yacht Club, "Yachting Cup 2005," http://www.sdyc.org/raceinfo/yachtingcup Accessed July 2005.

${ }^{29}$ Taggart, Bonny. 2005. Morgan Invasion at Catalina's Isthmus. Santana, June, 45.

${ }^{30}$ James, Kitty. 2005. Sir Thomas Lipton Regatta. Santana, June, 36.

${ }^{31}$ The Log. 2005. Northern California Racing. June 24-July 7, B1.

${ }^{32}$ California Department of Fish and Game, Marine

Region, "California Ocean Sport Fishing Regulations Map,” http://www.dfg.ca.gov/mrd/fishing_map.html Accessed August 30, 2005.

${ }^{33}$ Parsons, G.R., E. C. Helm, and T. Bondelid. 2003. Measuring the Economic Benefits of Water Quality Improvements to Recreational Users in Six Northeastern States: An Application of the Random Utility Maximization Model. Funded by the U.S. Environmental Protection Agency's Office of Policy, Economics, and Innovation through Cooperative Agreement CR82486-01-0.

${ }^{34}$ Schramm, H.L., P. D. Gerard, and D. A. Gill. 2003. The Importance of Environmental Quality and Catch Potential to Fishing Site Selection by 
Freshwater Anglers in Mississippi. North American Journal of Fisheries Management 23:512-522.

${ }^{35}$ California Game and Fish, "36 Great California Fishing Trips,"

http://www.californiagameandfish.com/fishing/ca_aa 020804a/ Accessed August 22, 2005.

${ }^{36}$ Carrie Pomeroy. August 22, 2005. California Sea

Grant Marine Advisor UCCE Santa Cruz County, personal communication.

${ }^{37}$ Conlon, Michael. 2002. Northwest Mexico Marina Market Analysis. Prepared for the Packard

Foundation, EDAW, i-2.

${ }^{38}$ Conlon, Michael. 2002. Northwest Mexico Marina Market Analysis. Prepared for the Packard

Foundation, EDAW, i-6-i-7.

${ }^{39}$ Rains, John E. 2005. Resort Announces

Anniversary Deals. Sea, July, 30.

${ }^{40}$ Wallace, Don. 2005. Return to Palmilla. Yachting, July, Pg. 88.

${ }^{41}$ Wallace, Don. 2005. Return to Palmilla. Yachting, July, Pg. 88.

${ }^{42}$ Conlon, Michael. 2002. Northwest Mexico Marina

Market Analysis. Prepared for the Packard

Foundation, EDAW, i-1-i-2.

${ }^{43}$ Aguilar-Hernández, Yoal. July 26, 2005.

Coordinator of Ecology Port of Ensenada, personal communication.

${ }^{44}$ Escalera Nautica, "Escalera Nautica of the Sea of Cortes: The Tourism Megaproject of the XXI Century Official Basic Document," http://escaleranautica.com/general2.html Accessed July 2005.

${ }^{45}$ Escalera Nautica, "Escalera Nautica of the Sea of Cortes: The Tourism Megaproject of the XXI Century Official Basic Document," http://escaleranautica.com/general2.html Accessed July 2005.

${ }^{46}$ Escalera Nautica, "Escalera Nautica of the Sea of Cortes: The Tourism Megaproject of the XXI Century Official Basic Document,” http://escaleranautica.com/general2.html Accessed July 2005.

${ }^{47}$ Belleza, Robert A. 2005. Newport to Ensenada Yacht Race. California Tour and Travel, Spring, 13.

${ }^{48}$ Southwestern Yacht Club, "San Diego to Ensenada International Yacht Race,”

http://www.southwesternyc.org/SDtoEnsenada

Accessed July 2005.

${ }^{49}$ Baja Ha-Ha, Inc., "How to Ha-Ha,"

http://www.baja-haha.com/HowTo.html Accessed July 2005.

${ }^{50}$ International Sailing Federation, "Puerto Vallarta Race,"

http://www.sailing.org/default.asp?ID=j6 FhtA1w\&f ormat=popup Accessed August 2005.
${ }^{51}$ Los Sueños del Mar, "San Diego to Bahia de Manzanillo Yacht Race 2004,”

http://www.lossuenosdelmar.com/news_specials.html Accessed August 2005.

${ }^{52}$ The Log. FishRap Map. 2005. June 24-July 7, C9.

${ }^{53}$ Mexico Gobierno de La Republica, "President

Vicente Fox Supervises Tourist Infrastructure Works in Sea of Cortez Press Release 04/01/2005,”

http://envivo.presidencia.gob.mx/?P=42\&Orden=Lee r\&Tipo=\&Art=9212 Accessed July 2005.

${ }^{54}$ Serrano, Isela. "Sin cuajar, turismo náutico.” El

Universal, August 7, 2005,

http://www2.eluniversal.com.mx/pls/impreso/noticia

_supl.html?id_articulo=24117\&tabla=articulos

Accessed August 11, 2005.

${ }^{55}$ Escalera Nautica, "Escalera Nautica of the Sea of

Cortes: The Tourism Megaproject of the XXI

Century Official Basic Document,"

http://escaleranautica.com/general2.html Accessed July 2005.

${ }^{56}$ Aridjis, Homero. "Collapse of the Nautical

Ladder.” Reforma, January 19, 2003,

http://www.dickrussell.org/articles/homero38.htm

Accessed July 2005.

${ }^{57}$ Escalera Nautica, "Escalera Nautica of the Sea of Cortes: The Tourism Megaproject of the XXI

Century Official Basic Document,”

http://escaleranautica.com/general2.html Accessed

July 2005.

${ }^{58}$ Conlon, Michael. 2002. Northwest Mexico Marina

Market Analysis. Prepared for the Packard

Foundation, EDAW, 19.

${ }^{59}$ Conlon, Michael. 2002. Northwest Mexico Marina

Market Analysis. Prepared for the Packard

Foundation, EDAW, 30.

${ }^{60}$ Conlon, Michael. 2002. Northwest Mexico Marina

Market Analysis. Prepared for the Packard

Foundation, EDAW, i-5.

${ }^{61}$ Dibble, Sandra. "Government contradicted on plan for Sea of Cortés.” San Diego Union Tribune, January 16, 2003,

http://www.signonsandiego.com/news/mexico/20030 116-9999_1n16escalera.html Accessed August 10, 2005.

${ }^{62}$ Enciso, Angélica. "La Escalera Náutica, proyecto fantasma.” La Jornada, May 23, 2005,

http://www.jornada.unam.mx/2005/may05/050523/0

48n1pol.php Accessed July 7, 2005.

${ }^{63}$ Serrano, Isela. "Sin cuajar, turismo náutico.” El

Universal, August 7, 2005,

http://www2.eluniversal.com.mx/pls/impreso/noticia

_supl.html?id_articulo=24117\&tabla=articulos

Accessed August 11, 2005. 
${ }^{64}$ Fondo Nacional de Fomento al Turismo, "Mar de Cortés," http://www.fonatur.gob.mx Accessed August 2005.

${ }^{65}$ Enciso, Angélica. "La Escalera Náutica, proyecto fantasma.” La Jornada, May 23, 2005,

http://www.jornada.unam.mx/2005/may05/050523/0

48n1pol.php Accessed: July 7, 2005.

${ }^{66}$ Serrano, Isela. "Sin cuajar, turismo náutico." El

Universal, August 7, 2005,

http://www2.eluniversal.com.mx/pls/impreso/noticia _supl.html?id_articulo=24117\&tabla=articulos

Accessed August 11, 2005.

${ }^{67}$ Acosta, Guillermo. August 16, 2005. Coordinator of the Program of Integral Tourist Regions of Fonatur, personal communication.

${ }^{68}$ Ellig, Connie. "Streamlined Port Clearance Opens in Ensenada." Baja Times, February 15, 2005,

http://www.ensenadagazette.com/cis2_05.html Accessed July 5, 2005.

${ }^{69}$ Puerto de Ensenada, "Centro Integral de Servicios," http://www.puertoensenada.com.mx/cis.htm Accessed October 2005.

70 'Lectronic Latitude, "Domestic Clearing is Over in Mexico,"

http://www.latitude38.com/LectronicLat/2005/0405/ Apr19/Apr19.html Accessed July 2005.

${ }^{71}$ Latitude Letters. 2005. Long Lines and Long Hours in Mexico. Latitude 38, June, 52.

${ }^{72}$ Latitude Letters. 2005. We'll Probably Stay in Mexico Another Year. Latitude 38, June, 60. 


\section{Why Aquatic Invasive Species due to Boating and Shipping are a Problem - Introduction}

This section will introduce the concept that aquatic invasive species (AIS), including those carried by ships and boats, are an increasing problem for North America's ecosystems and economy. Sections VI, VII, VIII and IX will discuss:

1. impacts of specific AIS introduced via hull fouling in California and significant examples from other areas;

2. examples of AIS with significant impacts that were introduced by other vectors;

3. how hull-borne introductions AIS may be prevented or managed; and

4. the interplay of antifouling pollution and hull-borne AIS issues.

Invasive species threaten biological diversity and ecological integrity worldwide. They can permanently reduce biodiversity by preying on, parasitizing, out-competing, causing or carrying diseases, or altering habitats of native species. Some cause or carry human diseases or foster other species that do. ${ }^{1}$ As their populations explode, invaders may transform entire ecosystems, pushing native species to the brink of extinction. Some scientists believe that the threat posed by invasive species is second only to that posed by habitat loss; others consider invasive species to be the greater threat. $^{2}$

These drastic effects occur in part because non-indigenous species thrive in the absence of their natural competitors, diseases, parasites and predators. ${ }^{3}$

Bioinvasions may also affect local and regional economies because dramatic losses in diversity of native species can adversely affect aquaculture and commercial and recreational fishing. ${ }^{4}$ Biodiversity and socioeconomic impacts of biodiversity losses are discussed more fully in Section II of this report.

Hull-borne invasive species can cause severe economic and ecological damage. Some can damage shorelines, man-made marine structures, equipment, and vessels, requiring costly repair or replacement. Eradication programs are particularly expensive; see Section VIII of this report for more information.

Global trade and travel continue to increase, creating opportunities for new bioinvasions. Since the North American Free Trade Agreement (NAFTA) was implemented, trade has grown as much as five-fold among NAFTA partners. Unquestionably, growth in trade and travel, coupled with liberalized customs policies among NAFTA nations, has escalated transportation of plant, animal and microbial species and raised the odds of bioinvasions in North American ecosystems. $^{5}$

Invasive species were a contributing or causal factor in $68 \%$ of the extinctions of North American fish in the twentieth century. ${ }^{6}$ Because an invasive species is capable of reproduction, once introduced its concentration can increase, it can spread over a large area and it can persist indefinitely. In comparison, a discharge of pollution will not reproduce and may dissipate or biodegrade over time. ${ }^{7}$

As more invasive species become established in new areas and adapt to a variety of environments, the invasion rate can be expected to increase as they are disseminated to adjacent regions and harbors. ${ }^{8}$ 
According to a study on invasions of coastal marine communities in North America, shipping was the sole vector for $51 \%$ of 298 AIS identified in marine and estuarine waters and was responsible for almost half of the known invasions on the West Coast. Indeed, more AIS are present along the Pacific coast than the Atlantic and Gulf coasts. Most of the AIS on the West Coast (53\%) were native to the Indo-Pacific and the Western Atlantic. ${ }^{9}$

All mainland coasts of the United States (Atlantic, Pacific, Gulf of Mexico and Great Lakes), as well as coastal waters of Alaska, Hawaii and other Pacific islands, have felt the effects of accelerating, aquatic bioinvasions. ${ }^{10}$ A study of 316 invasive species of invertebrates and algae established in North America attributed 164 (52\%) introductions to shipping and it was considered one of multiple, possible vectors for another 87 (27.5\%) introductions. The study reported that most (66\%) of the shipping-associated invasions occurred on the Pacific coast, 31\% occurred on the Atlantic coast and 4\% occurred on the Gulf coast. $^{11}$

Once invasive species enter the local marine environment, they will likely remain forever. They interact with existing communities and in the process modify native habitats. This can occur through increasing predation pressure on native organisms, such as the European green crab (Carcinus maenas) in California. In the Mediterranean Sea the invasive seaweed Caulerpa taxifolia overgrows both rocky and soft-bottom habitat and is unpalatable to many marine animals that depend on submerged vegetation. ${ }^{12}$ In Australia, the black-striped mussel (Mytilopsis sallei) smothers habitat ${ }^{13}$ and the New Zealand screwshell (Maoricolpus roseus) changes the seabed to a dense cover of live and dead shells. ${ }^{14}$

Sometimes, environmental modifications caused by one species enhance opportunities for other introduced species to survive and become invasive. ${ }^{15}$ This effect is sometimes called "invasional meltdown." 16

The primary socio-economic impacts of AIS are negative effects on human health and on economic productivity that depends on marine environments and resources. AIS can introduce parasites and pathogens. ${ }^{17}$ The Chinese mitten crab carries a parasite called the lung fluke, which can injure the lung or the brain, if the crab is eaten uncooked or undercooked. ${ }^{18} 19$ The club sea squirt, Styela clava causes an asthmatic condition in oyster shuckers if they hammer open Styelafouled oysters in poorly ventilated areas. ${ }^{20}$ In addition, Cholera (Vibrio cholerae) bacteria causes the deadly disease cholera and can be transported via ships' ballast water. It is the vector responsible for the cholera epidemic that began in Peru in 1991 and eventually spread through much of South America, killing 10,000 people and affecting many more. This strain previously was only known to have existed in Bangladesh. $^{21}$

Other examples include fisheries, aquaculture, tourism and marine infrastructure. These effects have related social impacts through decreases in employment in activities directly affected by invasive species. For example, the European green crab (Carcinus maenas) competes with the native Dungeness crab (Cancer magister), an important commercial species from San Francisco Bay to Washington state. Another social impact is the decrease in quality of life of local communities as AIS alter the natural surrounding environment. ${ }^{22}$ For example, Caulerpa 
taxifolia now encroaches on thousands of acres in the Mediterranean Sea, smothering essential habitat for fish and other marine life that people enjoy consuming or viewing or that are critical to the region's ecosystems. $^{23} 24$

Ecological and economic consequences of marine bioinvasions have been well documented. Expertise in a variety of fields, such as psychology, sociology, political science and anthropology, will be required to determine the full, socio-economic impacts of biodiversity losses. ${ }^{25}$ Questions that remain to be answered include: What social customs and norms have aided in the spread of AIS? Do current rules and regulations contribute to their control? Have actions taken by human beings, such as the destruction of marine environments, fostered the spread of non-indigenous marine species? ${ }^{26}$

\section{California}

The California Department of Fish and Game (CDFG) conducted a study to determine the location and range of invasive species populations along the California coast in 2000 and 2001. Based on their study, they prepared a list of non-indigenous species occurring in marine and estuarine waters of California. Overall, they found 360 species that were characterized as introduced to California's coastal ecosystems. They also found 247 species that were considered to be cryptogenic (of unknown origin), 14 species that were most likely introduced to the habitats where they were found during the study but were native elsewhere in California, and 126 species that were designated as non-distinct because taxonomists could not identify them to the species level and were thus uncertain about their origin. From 50 to nearly 250 species in each harbor area were either clearly introduced or considered very likely to have been introduced to the local environment. According to CDFG, over 80 aquatic invasive species have been introduced to California waters via hull fouling. ${ }^{27}$

Perhaps the best known AIS to have caused structural damage in California is the Atlantic shipworm (Teredo navalis), first introduced to California in 1913 via hull fouling. ${ }^{28}$ It caused between $\$ 2$ billion and $\$ 20$ billion worth of damage to maritime facilities in San Francisco Bay in the early $20^{\text {th }}$ century. ${ }^{29}$ The Atlantic shipworm will be discussed in more detail in Section VI of this report.

Together, ballast water discharges and hull fouling appear to be the primary mechanisms of introduction in all areas, except in the freshwater ports of Sacramento and Stockton and in the Sacramento/San Joaquin Delta. Hull fouling is the most common vector in four harbors: Humboldt Bay, Port Hueneme, Ports of Los Angeles and Long Beach, and San Diego Bay. Among the smaller harbors and bays sampled, hull fouling is the lead vector in eight of the twelve selected harbors and the second leading vector in the remaining four areas. This suggests that hull fouling plays a more important role in smaller ports than in larger ones. ${ }^{30}$

Overall, the most invasive species are found in California's two major commercial ports, San Francisco and Los Angeles/Long Beach. The smaller commercial ports (Humboldt Bay, Sacramento, Stockton, Port Hueneme and San Diego), the Sacramento/San Joaquin Delta, and many small harbors and bays along the coast also have a significant number of invasive species. ${ }^{31}$ Although the CDFG's sampling program targeted areas most likely to be impacted by ballast introductions, invasions due to hull transport 
or ballast water can be difficult to distinguish. ${ }^{32}$ Over 80 species were introduced by hull fouling. The majority of species introduced to California appear to have come from the northwest Atlantic, the northwest Pacific and the northeast Atlantic. California receives much ship traffic and source materials for aquaculture from these regions. ${ }^{33}$

\section{Northern California}

San Francisco Bay continues to be one of the most invaded ecosystems in California ${ }^{34}$ and in the world. ${ }^{35}$ Over 175 exotic species are established in its salt and brackish tidal waters and over 75 other species are established in the Sacramento-San Joaquin Delta. Perhaps another 100-200 species are considered "cryptogenic" in San Francisco Bay, i.e. whether they are native or exotic is unknown. ${ }^{36}$

An analysis of the San Francisco Bay and Delta ecosystem found that exotic species dominate many habitats in terms of number of species, number of individuals, biomass and a high and accelerating rate of invasion. In some regions of the Bay introduced species comprise all of the common species or the majority of the species diversity. ${ }^{37}$ Possible causes are the large number and variety of transport vectors, from large commercial ships to small recreational boats. Most of the marine invasive species originated in the North Atlantic and western North Pacific. A 1998 study found 26\% of invasive species in San Francisco Bay were introduced by hull fouling. ${ }^{38}$

The greatest economic impacts to the San Francisco Bay estuary may occur because the estuary's ecosystem has been destabilized by the introduction and establishment on average of one new species every 24 weeks. These changes have hindered efforts to manage the estuary with the goal of sustaining healthy populations of marine species. Further, water diversions, wastewater discharges, levee maintenance, construction and other economic activity near the estuary have been affected, which has impacted the economy of the entire state. ${ }^{39}$ These problems are discussed in more detail in Section VII of this report.

A study of Humboldt Bay in 2000 identified 95 possible non-indigenous species and 65 species that are clearly invasive. Although some species have been intentionally introduced to Humboldt Bay, such as the Japanese oyster, others may have arrived as a result of increased maritime trade and other activities. Some ships enter the bay after visiting ports along the West Coast and fishing boats regularly visit ports in Oregon, Washington, and Alaska, although most vessels come from San Francisco Bay. Because they are generally not as rigorously maintained as commercial ships, fishing boats and pleasure craft capable of ocean voyages may transport invasive species via hull fouling.

\section{Central California}

The absolute number of non-native species in the Elkhorn Slough estuary in Central California is about ten times higher than along the open coast. Fieldwork and a literature review revealed 56 known invasive species of which $70 \%$ are associated with hull fouling. They may have been introduced from San Francisco or other regional ports by currents or on hulls of boats that acquired them while anchored in areas with abundant, established populations of invaders. Moreover, non-native species accounted for over $10 \%$ of estuarine animal species but less than $1 \%$ of open coast animal species. These results may be due to 
boats and other vectors that carry invasive propagules into estuaries.

The effect of international shipping on invasive species introductions thus extends to both commercial ports and isolated embayments, such as Elkhorn Slough. ${ }^{40}$

\section{Southern California}

Most of the AIS collected in 2000 during a Southern California survey were native to the northwestern Pacific, primarily Japan, Korea, and northern China. Hull transport was a possible vector for two-thirds of the reported invasive species. The report was based on a Rapid Assessment Survey of a representative sample of sheltered waters between San Diego and Oxnard in 2000. ${ }^{41}$

Nonindigenous ascidians (often called sea squirts or tunicates), for example Styela clava, Styela plicata ${ }^{42}$ and Ciona intestinalis, ${ }^{43}$ have spread and persisted in San Diego and other Southern California harbors and have replaced native species. Microcosmus squamiger, Ciona savignyi, Symplegma oceania and Polyandrocarpa, have been found from San Diego Bay to Ventura. Their abundance in all Southern California harbors raises concerns that they may persist, spread and displace native species. $^{44}$

\section{Pollution and Aquatic Invasive Species}

Current and future restrictions on heavymetal, antifouling paints could exacerbate invasions. Recently, improved water quality in many harbors and ports around the world may also lead to more abundant and diverse fouling communities that could colonize the hulls of visiting ships. ${ }^{45}$ The recent decline in use of certain antifouling compounds, such as tributyl tin, may increase fouling communities on some vessels if other maintenance practices are not employed. ${ }^{46}$

On the other hand, native ecosystems may flourish and become more resistant to invasions as water quality improves. Studies indicate that some invasive fouling species are more tolerant of copper and tributyl tin than native species and that certain other AIS benefit from highly polluted environments. ${ }^{474849} 50$ This suggests that improving coastal water quality by reducing pollution from antifouling paints could help ecosystems resist hull-borne invasions.

See Section IX for more information on ecological and other implications of policies to reduce antifouling paint pollution and to prevent hull-borne transport of aquatic invasive species.

\section{References}

\footnotetext{
${ }^{1}$ Brancato, M.S. and D. MacLellan. 1999. Impacts of Invasive Species Introduced through the Shipping Industry (abstract). Oceans 1999 MTS/IEEE. Riding the Crest into the $21^{\text {st }}$ Century. Volume 2: 676. September 13-16, 1999. Seattle, WA. ISBN: 0-78035628-4.

${ }^{2}$ Veitch, C. R. and M. N. Clout. 2004. Turning the Tide: The Eradication of Invasive Species. Proceedings of the International Conference on Eradication of Island Invasives.

${ }^{3}$ Commission for Environmental Cooperation of North America. 2001. Preventing the Introduction and Spread of Aquatic Invasive Species in North America: Workshop Proceedings. March 28-30, 2001.

<http://www.cec.org/files/PDF/BIODIVERSITY/aqu atic-invasives_en.pdf $>$ Accessed October 31, 2005.

${ }^{4}$ Brancato, M.S. and D. MacLellan. 1999. Impacts of Invasive Species Introduced through the Shipping Industry (abstract). Oceans 1999 MTS/IEEE. Riding the Crest into the $21^{\text {st }}$ Century. Volume 2: 676. September 13-16, 1999. Seattle, WA. ISBN: 0-78035628-4.

${ }^{5}$ Commission for Environmental Cooperation of North America. 2001. Preventing the Introduction and Spread of Aquatic Invasive Species in North America: Workshop Proceedings. March 28-30, 2001.
} 
<http://www.cec.org/files/PDF/BIODIVERSITY/aqu atic-invasives_en.pdf> Accessed October 31, 2005.

${ }^{6}$ Miller, R.R., J.D. Williams, and J.E. Williams. 1989. Extinctions of North American fishes during the past century. Fisheries 14(6): 22-38.

${ }^{7}$ Cohen, A.N. and P.B. Moyle. 2004. Summary of data and analyses indicating that exotic species have impaired the beneficial uses of certain California waters. Submitted to the State Water Resources Control Board on June 14, 2004.

${ }^{8}$ Bax, N., A. Williamson, M. Aguero, E. Gonzalez, and W. Geeves. 2003. Marine invasive alien species: a threat to global biodiversity. Marine Policy 27(4):313-323.

${ }^{9}$ Ruiz, G.M., P.W. Fofonoff, J.T. Carlton, M.J. Wonham and A.H. Hines. 2000. Invasion of coastal marine communities in North America: Apparent patterns, processes, and biases. Annual Review of Ecology and Systematics 31:481-531.

${ }^{10}$ Brandt, S.B. 2003. Written Testimony before the Subcommittee on Fisheries Conservation, Wildlife, and Oceans and the Subcommittee on National Parks, Recreation, and Public Lands. House Resource Committee. April 29, 2003. Dr. Brandt is the Director of the Great Lakes Environmental Research

Laboratory.

${ }^{11}$ Fofonoff, P.W., G.W. Ruiz, B. Steves, and J.T. Carlton. 2003. In ships or on ships? Mechanisms of transfer and invasion for non-native species to the coasts of North America. Pages 152-182 in Ruiz, G.M. and J.T. Calrton (eds). Invasive species: vectors and management strategies. Island Press, Washington.

${ }^{12}$ Bax, N., A. Williamson, M. Aguero, E. Gonzalez, and W. Geeves. 2003. Marine invasive alien species: a threat to global biodiversity. Marine Policy 27(4): 313-323.

${ }^{13}$ Bax, N., A. Williamson, M. Aguero, E. Gonzalez, and W. Geeves. 2003. Marine invasive alien species: a threat to global biodiversity. Marine Policy 27(4): 313-323.

${ }^{14}$ Bax, N.J. and A. Williams. 2001. Seabed habitat on the southeast Australian continental shelf-context vulnerability and monitoring. Marine and Freshwater Research 52: 491-512.

${ }^{15}$ Bax, N., A. Williamson, M. Aguero, E. Gonzalez, and W. Geeves. 2003. Marine invasive alien species: a threat to global biodiversity. Marine Policy 27(4): 313-323.

${ }^{16}$ Simberloff, D. and B. von Holle. 1999. Positive interactions of non-indigenous species: invasional meltdown. Biological Invasions 1:21-32.

${ }^{17}$ Lerner, N. and P. Heimowitz. 2001. Aquatic Invasive Species: A Guide to Least-Wanted Aquatic
Organisms of the Pacific Northwest. Washington Sea Grant and Oregon Sea Grant. WSG-MR 00-02.

${ }^{18}$ California Department of Fish and Game. 2003.

California Aquatic Invasive Species Management

Plan. Draft.

${ }^{19}$ Veldhuizen, T. and K. Hieb. 1998. What

Difference Can One Crab Species Make? The

Ongoing Tale of the Chinese Mitten Crab and the San

Francisco Estuary. Outdoor California. Pg.19-21.

${ }^{20}$ Guide to the Exotic Species of San Francisco Bay, "Styela clava,"

http://www.exoticsguide.org/species_pages/s_clava.h tml Accessed: August 30, 2005.

${ }^{21}$ Raaymakers, S. 2002. The Ballast Water Problem: Global Ecological, Economic, and Human Health Impacts. Paper Presented at the RECSO/IMO Joint Seminar on Tanker Ballast Water Management \& Technologies Dubai, UAE 16-18 Dec 2002.

${ }^{22}$ Bax, N., A. Williamson, M. Aguero, E. Gonzalez, and W. Geeves. 2003. Marine invasive alien secies: a threat to global biodiversity. Marine Policy 27(4): 313-323.

${ }^{23}$ Meinesz, A. 1999. Killer Algae. Chicago, U.S.: University of Chicago Press.

${ }^{24}$ Relini, M. and Trochia, G. 2000. The role of fishing gear in the spreading of allochthonous species: the case of Caulerpa taxifolia in the Ligurian Sea. ICES Journal of Marine Science 57: 1421-1427.

${ }^{25}$ Perrings, C. and R. Ferris (eds). 2004. SocioEconomic Biodiversity Research Perspectives Relevant to the Delivery of the UK Biodiversity Action Plan. A Report to the UK Biodiversity Research Advisory Group.

${ }^{26}$ Perrings, C. and R. Ferris (eds). 2004. SocioEconomic Biodiversity Research Perspectives Relevant to the Delivery of the UK Biodiversity Action Plan. A Report to the UK Biodiversity Research Advisory Group.

${ }^{27}$ California Department of Fish and Game. 2002. A Survey of Non-Indigenous Aquatic Species in the Coastal and Estuarine Waters of California.

Submitted to the California State Legislature as required by the Ballast Water Management Act of 1999. Prepared and submitted by the Department of Fish and Game, Office of Spill Prevention and Response, December 2002. 33pp.

${ }^{28}$ United States Geological Survey.

$<$ http://cars.er.usgs.gov/Region_5_Report/html/isopo ds.html> Accessed June 272005.

${ }^{29}$ Cohen, Andrew N. 2004. Invasions in the Sea.

Park Science 22 (Fall): 37-41.

${ }^{30}$ California Department of Fish and Game. 2002. A Survey of Non-Indigenous Aquatic Species in the Coastal and Estuarine Waters of California. 
Submitted to the California State Legislature as required by the Ballast Water Management Act of 1999. Prepared and submitted by the Department of Fish and Game, Office of Spill Prevention and Response, December 2002. 33pp.

${ }^{31}$ California Department of Fish and Game. 2002. A Survey of Non-Indigenous Aquatic Species in the Coastal and Estuarine Waters of California. Submitted to the California State Legislature as required by the Ballast Water Management Act of 1999. Prepared and submitted by the Department of Fish and Game, Office of Spill Prevention and Response, December 2002. 33pp.

${ }^{32}$ Cohen, A.N. and J.T. Carlton. 1995. Nonindigenous species in a United States Estuary: A case study of the biological invasions of the San Francisco Bay and Delta. Report of the United States Fish and Wildlife Service, Washington DC and the National Sea Grant College Program Connecticut Sea Grant. CONN-T-95-002.

${ }_{33}$ California Department of Fish and Game. 2002. A Survey of Non-Indigenous Aquatic Species in the Coastal and Estuarine Waters of California. Submitted to the California State Legislature as required by the Ballast Water Management Act of 1999. Prepared and submitted by the Department of Fish and Game, Office of Spill Prevention and Response, December 2002. 33pp.

${ }^{34}$ Cohen, A.N. and J.T. Carlton. 1995.

Nonindigenous species in a United States Estuary: A case study of the biological invasions of the San Francisco Bay and Delta. Report of the United States Fish and Wildlife Service, Washington DC and the National Sea Grant College Program Connecticut Sea Grant. CONN-T-95-002.

${ }^{35}$ Cohen, A. N. and J. T. Carlton. 1998. Accelerating Invasion Rate in a Highly Invaded Estuary. Science 279:555-558.

${ }^{36}$ Cohen, Andrew N. 2005 Guide to the Exotic Species of San Francisco Bay.

San Francisco Estuary Institute, Oakland, CA, $<$ www.exoticsguide.org> Accessed August 31, 2005

${ }^{37}$ Cohen, A.N. and J.T. Carlton. 1995.

Nonindigenous species in a United States Estuary: A case study of the biological invasions of the San Francisco Bay and Delta. Report of the United States Fish and Wildlife Service, Washington DC and the National Sea Grant College Program Connecticut Sea Grant. CONN-T-95-002.

${ }^{38}$ Cohen, A.N. and J.T. Carlton. 1998. Accelerating Invasion Rate in a Highly Invaded Estuary. Science 279: 555-557.

${ }^{39}$ Cohen, A.N. and J.T. Carlton. 1995.

Nonindigenous species in a United States Estuary: A case study of the biological invasions of the San
Francisco Bay and Delta. Report of the United States Fish and Wildlife Service, Washington DC and the National Sea Grant College Program Connecticut Sea Grant. CONN-T-95-002.

${ }^{40}$ Wasson, K., C.J. Zabin, L. Bedinger, M.C. Diaz, and J.S. Pearse. 2001. Biological invasions of estuaries without international shipping: the importance of intraregional transport. Biological Conservation 102: 143-153.

${ }^{41}$ Cohen, A.N., L.H. Harris, B.L. Bingham, J.T. Carlton, J.W. Chapman, C.C. Lambert, G. Lambert, J.C. Ljubenkov, S.N. Murray, L.C. Rao, K. Reardon and E. Schwindt. 2002. A Rapid Assessment Survey of Exotic Species in Sheltered Coastal Waters. For the California Department of Fish and Game, Sacramento, CA, the State Water Resources Control Board, Sacramento, CA and the National Fish and Wildlife Foundation, San Francisco, CA.

${ }^{42}$ Abbott, D.P. and J.V. Johnson. 1972. The ascidians Styela barnharti, S. Plicata, S. clava, and S. montereyensis in Californian waters. Bulletin of the Southern California Academy of Sciences 71: 95-105. ${ }^{43}$ Lambert, C. and G. Lambert. 1996. Ascidian introductions into Southern California harbors and marinas. From Workshop proceedings: Marine and aquatic non-indigenous species in California: An assessment of current status and research needs. Sponsored by the California Sea Grant College System. San Francisco, CA. October 18-19, 1996. Report No.T-043.

${ }^{44}$ Lambert, C. and G. Lambert. 1996. Ascidian introductions into Southern California harbors and marinas. From Workshop proceedings: Marine and aquatic non-indigenous species in California: An assessment of current status and research needs. Sponsored by the California Sea Grant College System. San Francisco, CA. October 18-19, 1996. Report No.T-043.

${ }^{45}$ Carlton, J.T. 1996. Pattern, process, and prediction in marine invasion ecology. Biological Conservation 78: 97-106.

${ }^{46}$ Nehring, S. 2001. After the TBT era: alternative antifouling paints and their ecological risks. Senckenbergiana Maritima 31: 341-351.

${ }^{47}$ Piola, R.F. and E.L. Johnston. 2005. Differential tolerance to metals among populations of the introduced bryozoan Bugula neritina. Marine Biology (Published Online, November 2005).

${ }^{48}$ Hall, A. 1981. Copper accumulation in copper tolerant and non-tolerant populations of the marine fouling alga, Ectocarpus siliculosus (Dillwyn) Lyngbye. Botanic Marina 24:223-228.

${ }^{49}$ Russell, G. and O.P. Morris. 1973. Ship fouling as an evolutionary process. Proceedings of the $3^{\text {rd }}$ 
International Congress of Marine Corrosion and

Fouling: 719-730. Washington, DC, 1972.

${ }^{50}$ Crooks, J. 2005. Oral commentary. Vessel Fouling

Technical Advisory Group, October 13, 2005:

Meeting Summary. California State Lands

Commission, Sacramento, CA. 


\section{Hull-Borne, Aquatic Invasive Species and Their Impacts}

In general, hull-borne aquatic invasive species (AIS) have adaptations and life histories that facilitate their attachment to the hull of a vessel. For example, some species may live attached to hard surfaces or have the ability to burrow into hard surfaces. Other hull-borne species, at some point in their life history, are able to nestle among or cling to fouling growth so that they are not swept away by currents or hull motion.

As discussed in Section V of this report, aquatic bioinvasions can damage shorelines and structures. Most significant and longlasting are the effects of invasive species on the ecosystem of the recipient region. ${ }^{12345}$ Unfortunately, the effects of ecosystem changes and their socio-economic impacts may take longer to appear and may be more challenging to understand and remediate than structural damages. Programs to control or eradicate bioinvasions can be burdensome and expensive, as illustrated by some of the examples presented in this section. Indeed, true cases of eradication are very rare for marine invasions, regardless of the investment made. ${ }^{6}$ Well-designed, prevention programs, although inconvenient, can be more cost effective in the long term for boat owners, other marine and aquatic resource users, management agencies and tax payers.

This section will present examples of invasive species that were likely transported on vessel hulls and their impacts on recipient regions. The primary focus will be on the recipient regions of California and Baja California. Examples will also be included from other parts of the United States and Canada. Hawaii, Australia and New Zealand have recognized the problem of hull-borne invasions and have employed control measures for many years; examples from these areas will also be discussed. It is important to note that the some of these species may have been introduced much earlier than the date of their discovery.

\section{CALIFORNIA AND BAJA CALIFORNIA}

\section{MOLLUSCS}

Molluscs include popular seafood species such as scallops, clams, oysters, abalone, conch, squid and octopus. Some of the most damaging marine pests are bivalve (twoshelled) molluscs, such as shipworms and zebra mussels.

\section{Pacific shipworm (Bankia setacea)}

Shipworms have been recognized throughout history as a serious pest that bores into and damages wooden structures and vessels. In 1852, the U.S. Navy chose northern San Francisco Bay as a Pacific base because the water is too fresh for the Pacific shipworm (Bankia setacea). ${ }^{7}$

\section{Atlantic Shipworm (Teredo navalis)} Unfortunately, the Atlantic shipworm (Teredo navalis) tolerates lower salinity than the Pacific shipworm. It was introduced by ship to San Francisco Bay in 1919. It multiplied rapidly and bored its way through the available habitat "dropping wharves, piers, ferry slips, and other maritime facilities into the water at an average rate of one major structure every two weeks for a period of two years."

Teredo navalis is a bivalve mollusc with a wormlike body and a short, helmet-like shell at the forward end. It lives embedded in wood. Although it can filter and digest plankton from the seawater, it can survive on a strictly wooden diet. ${ }^{9}$ 
Historians believe that by 1000 B.C. the Phoenicians and Egyptians were coating their ships with pitch and wax to protect them from shipworms and other harmful organisms. Further, by 350 B.C., Greeks and Romans are believed to have coated their ships with lead, pitch and tar for the same reason. ${ }^{10}$ Even Christopher Columbus is said to have contended with these "sea termites."11 Between 1500 and 1600, seafarers attempted to protect wooden boat bottoms by covering them with a variety of materials, such as "heavy black tar, pitch, calfskin, cows' hair, ashes, glue, moss and

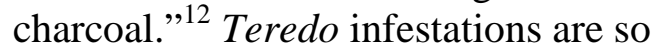
common that the humorous nickname "Johnny Shipwormseed" has been applied to boats whose wooden hulls carry them. ${ }^{13}$

According to a report by the San Francisco Bay Marine Piling Committee, in December 1919, Teredo navalis severely damaged pilings of Southern Pacific slips at Port Costa and Benicia, boring through them completely in some instances. Similarly, in 1920, pilings in Pinole, Oleum, Mare Island, Vallejo, Crockett, Martinez, and Avon were all destroyed by Teredo. The collapse of these wharves near the San Pablo Bay caused \$15 million in damages, and was the decisive factor in creating the San Francisco Bay Marine Piling Committee. ${ }^{14}$ According to Cohen and Carlton, Teredo caused US\$615 million (in 1992 dollars) of structural damage to maritime facilities in just three years. ${ }^{15}$ In current dollars, Teredo navalis caused between $\$ 2$ billion and \$20 billion in damages to maritime facilities in San Francisco Bay in the early $20^{\text {th }}$ century. ${ }^{16}$

Wood-boring organisms were a significant issue for commercial vessels in the days of wooden ships. Today, they primarily affect smaller vessels that still use some or all wood for their structure. ${ }^{17}$

\section{Eurasian Zebra Mussel (Dreissena polymorpha)}

One of the most widely known invasive species transported by recreational boats across much of the United Sates is the Eurasian zebra mussel (Dreissena polymorpha). It was introduced in 1988 to Lake St. Clair, near Detroit, from ships' ballast water. ${ }^{18}$ Although currently limited to regions east of the $100^{\text {th }}$ longitudinal meridian, ${ }^{19}$ it potentially threatens California's lakes and streams. Today the primary vector of zebra mussels in the United States is overland transport on trailered, recreational boats. It is also transported through waterbodies by other human activities and from natural spread.

Zebra mussels can attach and proliferate on any open, external surface, including aquatic plants. $^{20}$ They can compete with native species for food, disrupt food cycles, and clog "water intake pipes, sluices and irrigation ditches." 21 In Europe, zebra mussels have periodically stopped the flow of consumable water intended for farms, small enterprises, and nonpublic use. Due to escalating fuel prices, the substantial "drag” caused by zebra mussels on boat hulls can influence pleasure craft owners' ability to afford fuel for their boats. ${ }^{22}$ For example, a 2005 survey by the Southern California boating newspaper, The Log, found that: $62.5 \%$ of readers who responded to the poll said that escalating gasoline prices would affect their boating plans for Labor Day weekend; 33.33\% planned to reduce the amount of time spent in open waters; $12.50 \%$ would only operate their boats inside the slips; and $16.67 \%$ would not take their boats out at all because of the escalating price of fuel. ${ }^{23}$ 


\section{ARTHROPODS - CRUSTACEANS}

Arthropod means "jointed leg." This large group includes insects, spiders, crustaceans and other familiar creatures.

Crustaceans include popular seafood species, such as lobster, shrimp and crab that actively swim or crawl. Barnacles are crustaceans that have swimming larvae, which eventually settle on and attach to marine surfaces. Barnacles feed by extending their legs from their protective shells to grab plankton from surrounding waters. Some of the most intriguing, antifouling research focuses on the glue used by barnacles to anchor themselves. Isopods are crustaceans related to the familiar garden pillbug or sowbug.

\section{Striped Barnacle (Balanus amphitrite)} The striped barnacle (Balanus amphitrite) from the Southwestern Pacific and Indian Oceans has been found in the San Francisco Bay and parts of Southern California. It was introduced by ship fouling and can thrive in bays and harbors in warm seas all over the world. It can cause serious biofouling problems. Studies show that it can reduce a ship's speed by up to $40 \%$ and increase fuel consumption. Dense accumulations of barnacles can also serve as refuges for other alien species such as the Harris mud crab (Rhithropanopeus harrisii). ${ }^{24}$

European Green Crab (Carcinus maenas) The European green crab (Carcinus maenas) has been especially devastating to California's marine ecosystems. Originally found on the Atlantic coast of Europe, this invasive species has spread to southern Australia, South Africa, Japan, and the United States. Green crabs are thought to have been introduced to the United States through ship hull transport, when they are in an early growth stage, or among rocks and mud loaded on ships for solid ballast. ${ }^{25} 26$

First reported in California in the 1980s, the green crab population has flourished and now extends from San Francisco Bay into the state of Washington. The green crab can modify entire ecosystems. ${ }^{27}$ It adjusts easily to new surroundings, menacing native species and the ecosystems of which they become a part. It can exhaust available food supplies, threatening survival of native crabs. This can affect other species that feed on native crabs. Its presence can have socioeconomic impacts if, for example, native species are important to the local economy or are staples or delicacies of the local diet.

Habitat and food preferences of juvenile green crabs are similar to those of the native Dungeness crab (Cancer magister), so it competes with this important commercial species. ${ }^{28}{ }^{29}$ Some scientists believe the green crab may harm Dungeness crab fisheries by preying on juveniles. ${ }^{30}$ The green crab also feeds upon cultured oysters, mussels, and native clams, such as Nutricola tantilla and $N$. confusa. ${ }^{31}$ The green crab has dramatically reduced the abundance of several key invertebrate species, including the native shore crab (Hemigrapsus oregonensis) and native clams Transennella confuse and T. tantilla, in San Francisco Bay. ${ }^{32}$

The green crab has at times been a pest of cultivated Manila clams (Venerupis philippinarum), in Tomales and Humboldt Bays. By entering and filling traps, it has sometimes been a pest of trap fisheries for eels in eastern Canada and for bait fish (gobies and sculpin) in San Francisco Bay. ${ }^{33}$

The green crab is widely believed to be responsible for the demise of the soft shell clam industry in the northern region of the 
U.S. Atlantic coast. ${ }^{34}$ Scientists fear that it will outcompete migratory bird populations on the west coast of North America for favored shellfish. ${ }^{35}$

\section{Australasian Isopod (Sphaeroma quoyanum)}

The burrowing Australasian isopod (Sphaeroma quoyanum) was introduced to San Francisco Bay through ship fouling from Australia and New Zealand in 1893 and quickly spread to other California bays and harbors in the same manner. ${ }^{36}$ It riddles banks on bay shores with half-centimeter diameter holes and scientists believe that its activities have caused shorelines in some regions to retreat by several meters. The isopod is also believed to have played a major role in erosion of intertidal soft rock terraces along the shore of San Pablo Bay, because its boring activity "weakens the rock and facilitates its removal by wave action."37

\section{ASCIDIANS}

Ascidians have tiny, swimming larvae that resemble primitive, eel-like ancestors of vertebrates to which they are related. They are most familiar, however, in their jellylike, sessile, adult form. Examples include sea squirts, sea vases and club tunicates.

\section{Star Sea Squirt (Botryllus schlosseri)}

Botryllus schlosseri, commonly known as the star sea squirt or the golden star tunicate, is believed to be native to Europe and "has probably been spread by ship fouling since ancient times." It can be found on both coasts of North America and, as intercoastal ship traffic continues to increase, such introductions will likely occur more frequently. ${ }^{38}$ It was first documented in San Francisco Bay in the 1940s and had become common on marina floats in San Diego by the 1960 s. $^{39}$
The star sea squirt fouls vessel hulls, aquaculture structures and other, man-made submerged structures. ${ }^{40}$ It can also overgrow and compete with cultured oysters and mussels and increase processing costs for these shellfish. ${ }^{41}$ Star sea squirts have recently been found on oyster farms in Nova Scotia, Canada, particularly affecting juvenile oysters on seed collectors. When they appear in great abundance they cover young oysters and kill them by restricting their access to flowing water, on which they rely for respiration and feeding. ${ }^{42}$

\section{Sea Vase (Ciona intenstinalis)}

The sea vase (Ciona intestinalis) is believed to be native to northern Europe and was documented in Newport Bay, California in 1949. "Huge populations occur during the spring and summer in the more sheltered regions of harbors from Los Angeles to San Diego." ${ }^{43}$ Its worldwide distribution is known to result from ship fouling. ${ }^{44}$

Ciona intestinalis has significant impacts on hanging aquaculture operations, such as mussels, oysters, and scallops. Its heavily concentrated bundles compete with the shellfish for food and add immense weight to the lines. The weight often causes cultured mussels to be pulled off their lines and fall to the bottom. Sea vases can easily overgrow mussels and nets to the point where mussels can no longer open their shells to feed. Severe fouling by sea vases has caused some eastern Canadian mussel farmers to go out of business; others struggle to stay in business. ${ }^{45}$

\section{Club Tunicate (Styela clava)}

Styela clava, commonly known as the club tunicate or club sea squirt, originated in Korea and was introduced to the British Isles, Australia, the U.S. Atlantic coast and California. It was first documented in 
Newport Harbor in 1933. It "probably arrived during the late 1920s on ship hulls or in ballast water or inadvertently with the import of Japanese oysters to Elkhorn Slough, with the subsequent ship transport along the California coast." ${ }^{46}$ Styela clava can reach densities of 500-1500 individuals per square meter, which significantly increases drag on vessels' hulls. ${ }^{47}$

It can be a major problem for shellfish aquaculture by competing with other organisms for space and food, or by consuming their planktonic larvae and thus reducing their rates of settlement. It is also known to affect human health in Japan, causing an asthmatic condition in oyster shuckers if they hammer open Styela-fouled oysters in poorly ventilated areas. ${ }^{48}$ Most recently, it has caused considerable damage to the native mussel industry in Prince Edward Island, Canada. The vitality of many of their mussel growing operations is in jeopardy and is causing concern to neighboring provinces, such as Nova Scotia, by significantly reducing native mussel production. $^{49}$

\section{ANNELIDS}

Annelids include the familiar earthworms, as well as marine polychaete worms, such as serpulid tubeworms that live on hard bottoms and sabellid tubeworms that have parasitized abalone in California. ${ }^{50}$

\section{Polychaete Serpulid Tubeworms (Hydroides diramphus and Hydroides elegans)}

Nuisance fouling by serpulid tubeworms is a problem for recreational boats in Southern California. In San Diego, they are commonly called coral, tube coral or South China Seas coral worm, because they live encased in a calcareous shell that resembles a small coral. Two invasive, serpulid tubeworms that have been distributed worldwide on ships' hulls are Hydroides diramphus and $H$. elegans. ${ }^{51}$ Hydroides elegans tends to occur in polluted harbors. ${ }^{52}$

The origin of these species is difficult to document because they occur in many places, such as Northern Europe, Australia, the Gulf of Mexico, the Caribbean Sea, the U.S. Atlantic coast, and Hawaii. 535455 Currently, all three species are found on boat hulls in San Diego Bay and are being introduced to Baja California. They are a problem because they produce copious amounts of calcareous tubes on submerged structures, including vessels, wharves, pontoons, and aquaculture equipment. In our work with the San Diego area boating community, we have learned that primary economic impacts of these tubeworms are attributed to the cost of cleaning fouled surfaces, increased drag on fouled vessels, damage to antifouling paints, and blockages or inefficiencies in seawater cooling systems. They may potentially affect the ecosystem by competing with other species for food and space. ${ }^{56}$ They pose a risk in Southern California and Baja California, where warm waters allow these subtropical species to thrive. ${ }^{57}$

\section{CNIDARIANS (COELENTERATES)}

Cnidarians, or Coelenterates, include jellyfish, sea anemones, hard corals and soft corals (sea fans).

\section{Spotted jellyfish (Phyllorhiza punctata)}

The invasive, spotted jellyfish (Phyllorhiza punctata), has been found in coastal areas of California. It can weigh as much as 22 pounds and can filter 50 cubic meters of water a day, consuming much of the available plankton. It preys on larval fish and competes with shrimp and fish for food. It is also a nuisance to fisheries because it 
can get caught in fishing nets. The attached polyp stage of this species, which buds off juvenile jellyfish, could be transported on vessel hulls. $^{58}$

\section{BRYOZOANS}

Most Bryozoans inhabit coastal waters and live in colonies attached to rocks, pilings, shells, algae and other animals. Their colonies often have a moss-like appearance, thus the common name moss animals.

\section{Spaghetti bryozoan (Zoobotryon verticillatum)}

The invasive, spaghetti bryozoan (Zoobotryon verticillatum) causes ecological and structural damage in California. Large masses of this species were reported in San Diego in 1902 and it had reached San Francisco Bay by $1992 .{ }^{59}$ Recently it has been reported in Seal Beach, California. ${ }^{60}$ Spaghetti bryozoans occur in bays and harbors and their populations can boom when the water is warmer than $22^{\circ} \mathrm{C}$. It is introduced among ship fouling and affects fisheries by fouling fishing gear. ${ }^{61}$ Despite their aesthetic beauty, the extended branches entangle and damage nets and may obstruct escape devices for sea turtles. Attached, spaghetti bryozoans may increase the risk that native species will be uprooted and thus disturb the local ecosystem. ${ }^{62}$

\section{Encrusting bryozoan (Watersipora subtorquata)}

The encrusting bryozoan (Watersipora subtorquata) was first collected in Southern California in Ventura County in 1963. The species probably reached the West Coast of North America as fouling on ship hulls. Watersipora subtorquata is less sensitive to copper than many fouling organisms. Therefore, once it colonizes a hull, it provides a surface for other species, which are more sensitive to copper, to settle. It is also capable of self-fertilization, making it easier for a small population, transported to a distant location, to become established. ${ }^{63}$ It is abundant in marinas where its thick, encrusting colonies are known as "Humboldt Bay coral." "64 In Japan it fouls both vessel hulls and oyster culturing operations. $^{65}$

\section{SEAWEEDS}

Seaweeds include major groups of the larger algae, for example green, brown and red. Many types of seaweed are important commercially as food (especially in Asian cuisine), fertilizer, sources of materials used in research laboratories (e.g. agar agar), nutritional supplements, or thickeners for foods such as ice cream and salad dressing. Giant kelp forests provide habitat for many species such as kelp bass, Garibaldi fish, sea otters and sea urchins along California's coast. Kelp stands also reduce intensity of waves before they reach the shore.

\section{Asian kelp (Undaria pinnatifida)}

The invasive brown alga known as Undaria pinnatifida is believed to be native to Japan, Korea, and China but also occurs on the Mediterranean coast of France, on the Atlantic coasts of Spain, England, and Argentina, on the coasts of New Zealand and Australia, and now on the Pacific Coast of the United States. It was first discovered in California in spring 2000 and by summer 2001 had colonized areas between Monterey Bay and Santa Catalina Island. It was recorded for the first time on the Mexican Pacific Coast in September 2003 at Todos Santos Island in Baja California by Raul Aguilar-Rosas and Luis Aguilar-Rosas. They attribute Undaria pinnatifida's presence in Baja California to the intense traffic of commercial vessels and cruise ships in Ensenada harbor and the introduction of gametophytes or tiny 
sporophytes attached to ship hulls or spores discharged from ship ballast water.

Ensenada harbor is a favorite destination for recreational boats mostly coming from California. ${ }^{66}$

This kelp competes with native marine life; it is likely to have major ecological impacts and affect the fishing industry. ${ }^{67}$ Undaria grows quickly and can crowd out native species of algae and other aquatic organisms, harming the local ecosystem. Because it can uproot native species and dominate available space, the Asian kelp also threatens shellfish industries. ${ }^{68}$ People who depend on harvesting native species may be forced to change their livelihood in response to changes caused by this invasive species. In addition, Undaria fouls boats, decreasing their efficiency. ${ }^{69}$

\section{OREGON, WASHINGTON AND BRITISH COLUMBIA}

Invasive species transported to the West Coast of the United States via ships' ballast water and hull fouling include the green crab (Carcinus maenas), mitten crab (Eriochir sinensis) and various tunicates, polychaete worms, and small crustaceans. ${ }^{70}$ The earliest record of an exotic marine species on the Pacific coast is an Atlantic Ocean barnacle that was collected in San Francisco Bay in 1853. Recent studies have documented hundreds of exotic species established within the reach of the tides, including 64 exotic species in Puget Sound, 57 in Willapa Bay, 61 in Coos Bay, 66 in Humboldt Bay, 65 in Elkhorn Slough and 106 in Southern California bays.

The situation in Oregon appears to be similar to that in California; increased marine traffic appears to be the primary reason for increases in aquatic bioinvasions. For example, the amount of cargo brought into the Port of Portland increased from 2,930 short tons in 1990 to 4,861 short tons in 2000 .

\section{Eurasian Zebra Mussel (Dreissena polymorpha)}

In recent years Oregon has created an annual "report card" for invasive species that includes the types found throughout the state, what the state is doing to combat them, and their success rates. In 2004, the Eurasian zebra mussel (Dreissena polymorpha) was on the list of " 100 most dangerous invaders threatening Oregon.”71 Zebra mussels, a freshwater species, are considered pests because they harm ship engines, compete with native species for food, and become a taxpayer's burden because of costs to repair blocked power plants and drainage systems. $^{72}$

\section{Blue Mussel (Mytilus galloprovincialis)}

The blue mussel (Mytilus galloprovincialis) has been established on the Pacific Coast of North America since the late 1800s. It has competitively excluded the native $M$. trossulus from much of its southern range on that coast. ${ }^{73}$ Hull fouling and/or ballast water are the suspected vectors of introduction. $^{74}$

\section{European Green Crab (Carcinus maenas)}

The European green crab (Carcinus maenas), first discovered in San Francisco Bay in 1989, has reached Oregon, Washington and British Columbia. Scientists believe it traveled to the United States by various vectors. Early life stages of the green crab can be carried on vessel hulls. In Washington, the green crab carries a parasitic worm that can be lethal to ducks. ${ }^{75}$ It has also threatened the United States' largest oyster-rearing industry in Washington. The green crab could potentially affect fisheries worth up to \$44 
million per year. If so, the state would incur costs for controlling the crab populations and from damage to its fisheries. ${ }^{76}$

The green crab competes with the native Dungeness crab (Cancer magister) for food, which in turn disturbs the food web in Oregon. ${ }^{77}$ The green crab could have a major impact on both the Dungeness crab and flatfish fisheries, such as the English sole (Pleuronectes vetulus). These two Pacific Northwest fisheries are collectively valued at US\$130 million to US\$135 million respectively, roughly split between Oregon and Washington. ${ }^{78} 79$ In addition, the green crab is aggressively colonizing Canada's East Coast, putting Canada's clam, mussel, and oyster industries at risk. The landed value of Atlantic clams, mussels, and oysters was about US\$57 million in 2000. On the Canadian West Coast, the Strait of Georgia is believed to be suitable habitat for green crab, which could dramatically affect local clam and crab fisheries. The landed value of native clams and crabs in British Columbia was approximately US\$25 million in $2000 .^{80}$

\section{Sea Squirt (Didemnum cf. Iahillei)}

Didemnum $c f$. lahillei, an invasive sea squirt, was found in Washington in 2004. The state's Department of Fish and Wildlife and Department of Agriculture and Ecology are concerned that this species may threaten the shellfish industry in Washington because of the effect it has had on the United States' Atlantic coast. This sea squirt can emit toxins and it can spread very quickly, suffocating clams, mussels, and other indigenous species. Although it probably arrived at Washington via ballast water, this sea squirt was found among fouling growth on an old sunken ship in Puget Sound. 818283 8485

\section{HAWAII}

Hawaii has been proactive in its efforts to curb aquatic nuisance species. A variety of species that are now found in Hawaii were transported there via ship hulls, including some species of Hydroides tubeworms.

\section{Blue Mussel (Mytilus galloprovincialis)} Blue mussels (Mytilus galloprovincialis) were part of the fouling community on the hull of the U.S.S. Missouri that was towed from Washington to Hawaii. The mussels are invasive to Hawaii and were observed spawning upon arrival at Pearl Harbor. Three months later, settled juveniles were recorded there. ${ }^{86}$ This species is of concern in Hawaii because it is an invasive pest on the Pacific coast of North America, where it has displaced the native $M$. trossulus from much of its southern range. ${ }^{87}$

\section{Snowflake Coral (Carijoa rïsei)}

The snowflake coral (Carijoa riisei) is a non-native species that has become a pest in Hawaii. First found in Honolulu in 1972, this soft coral species was either introduced to Hawaii via ship fouling or by accidental release from the marine ornamental aquarium industry. ${ }^{88}$ Initially, the snowflake coral was not considered a nuisance. However, when it was discovered in deeper regions where two, economically critical corals live, its status as a threat was elevated. Carijoa riisei overgrows the black coral at depths of 75 to 100 meters. Although the black corals in this depth range are too deep to be harvested by traditional methods, they are an important source of larvae for re-seeding the shallower portions of the population that are harvested. The two black coral species (Antipathes dichotoma and A. grandis) had generated US\$30 million in sales yearly prior to snowflake coral incursions. ${ }^{89}$

Although ecological impacts of many of the invasive species found in Hawaii have not 
been fully studied, experts believe that many compete with native species for space or food. ${ }^{90}$

\section{UNITED STATES ATLANTIC COAST}

Some of the invasive species that have been transported to the Atlantic Coast of the United States via ships' ballast water release and hull fouling include: Japanese shore crab (Hemigrapsus sanguineus), green crab (Carcinus maenas), and veined rapa whelk (Rapana veinosa). ${ }^{91}$ One of the earliest invasive species introduced from Europe to the United States Atlantic Coast in the mid 1800 s is the common periwinkle, (Littorina littorea). Although overall ecological effects of its introduction are unknown, scientists have theorized that some native molluscs, such as the eastern mud snail (Ilyanassa obsolete), were unable to compete and thus declined considerably in particular areas. ${ }^{92}$

In a study of Chesapeake Bay, 20\% of 196 invasive and cryptogenic species were thought to have some significant impact on the Bay's ecological populations, communities or habitats. ${ }^{93}$

University of Connecticut scientists are studying fouling species along the Eastern Seaboard and their survival on recreational boats. They are also examining boaters' assumptions about the effectiveness of fouling control measures, such as hull painting and scraping. Boats that travel from New England to Florida for the winter and return north in the spring could transport potentially invasive species if their hulls are not properly maintained. Each stop along the trip is an opportunity for an invasive organism to become established. ${ }^{94}$

\section{Atlantic shipworm (Teredo navalis)}

The Atlantic shipworm (Teredo navalis) has had a significant economic impact on the U.S. Atlantic Coast. The Port of Newark Marine Terminal recently spent approximately US\$8 million, some of which was used to restore wharves damaged by shipworms. In Edgewater, New Jersey, owners of a 614-unit condominium threatened to sue the developer for US\$18 million to compensate for Teredo damages to the pier that was the foundation for their building. ${ }^{95}$

The New York Department of Transportation spent \$6.1 million to inspect pilings that buttress waterfront roads and bridges and will incur more costs to repair damages. ${ }^{96}$ The Tiffany Street Pier was reconstructed in 2000 using 12 million, twoliter, recycled-plastic soda containers. ${ }^{97} 98$

In 2000, a University of Maine marine biologist discovered that $T$. navalis was responsible for the collapse of docks in Belfast seven months after construction. Harbor officials are considering expensive replacement of wooden pilings with cement, treating replacement wood with chemicals, or covering pilings with metal and fiberglass. Commercial fishermen are affected by Teredos that bore through wooden lobster traps. ${ }^{99} 100$

\section{UNITED STATES GULF COAST}

At least 544 non-indigenous species have been identified along the coast of the fivestate, Gulf of Mexico region. ${ }^{101}$ Invasive species transported to the Gulf Coast of the United States via ships' ballast water release, and hull fouling include the green mussel (Perna viridis) and brown mussel ( $P$. perna). ${ }^{102}$

UNITED STATES GREAT LAKES AND INTERIOR 
Great Lakes resource managers have been managing invasive species for over fifty years. The sea lamprey and alewife were key invaders of the Great Lakes in the 1950s; interconnecting canals aided their journey to the upper lakes. The sea lamprey caused the collapse of fish populations that were the economic mainstay of a Great Lakes fishery. ${ }^{103}$

The Great Lakes provide a path for freshwater-adapted invasive species to spread throughout the interior waters of the Central and Eastern United States. For example, the Eurasian zebra mussel (Dreissena polymorpha) has migrated from the Great Lakes-St. Lawrence River system throughout most of the eastern half of the United States. Zebra mussels have fouled industrial and municipal water intakes, which must now be chemically treated throughout the summer months to keep them flowing. Estimates of the annual cost of zebra mussel control and mitigation range from US\$100 million to US\$400 million per year in the Great Lakes basin, alone. ${ }^{104}$

\section{AUSTRALIA AND NEW ZEALAND}

Australia and New Zealand have stringent policies to control invasive species on ship and boat hulls.

\section{Australia}

Approximately 250 alien species occur in Australia. Five hundred private yachts and 16,500 other vessels may carry these species among the ports. Many of these species are known to affect recreational boating and other industries. If introduced to California, they could have similar impacts.

\section{Black-Striped Mussel (Mytilopsis sallei)}

The black-striped mussel (Mytilopsis sallei) is the most significant AIS to enter Australian tropical waters. It is closely related to the zebra mussel (Dreissena polymorpha), which congests channels and pipes and competes with native species in the United States. The black-striped mussel is considered a substantial threat to Australia's marine biodiversity and the competitiveness of its ports and shipping industries. It also threatens social and economic benefits provided by the aquaculture, recreational and commercial fishing, and tourism industries.

Black-striped mussels were first detected in three marinas in the harbor of Darwin, Australia in 1999. They were probably introduced on boat hulls or in the seawater piping of a recreational vessel from overseas. The infested marinas were quarantined and treated with chemicals that successfully eradicated it. The eradication project cost approximately AUS\$2.2 million. Since then, all vessels entering Darwin harbor are subject to a rigorous riskmanagement process to prevent future bioinvasions. The process includes risk assessment, visual inspection of high-risk vessels, and quarantine of vessels carrying potential marine pest species, such as unidentified bryozoans, black striped mussels, and Asian green mussels on their hulls. ${ }^{105}$ By 2003, 20 marine pest species had been excluded from Darwin's marinas, saving AUS\$44 million by avoiding eradication costs. ${ }^{106}$ Section VIII of this report discusses the eradication project and continuing risk-management program in more detail.

If it had become established, the blackstriped mussel might have caused the collapse of the valuable, northern Australian pearl industry by invading areas where pearl is harvested. It might also have infested 
vessels, outlet pipes, and other structures, requiring repeated, costly removal. ${ }^{107}$

\section{Asian Green Mussel (Perna viridis)} In 2001, the non-indigenous Asian green mussel (Perna viridis) was found on a vessel hull in Cairns harbor, Queensland, Australia. It caused concern in Australia because in India, China and Florida it rapidly infested boat hulls, water intake pipes and underwater walls. If green mussels were to have become established in Cairns harbor, the commercial value of the port could have been affected. ${ }^{108}$ Boat owners and the Australian government would have incurred costs for eradication.

Commonwealth, state and local agencies cooperated to identify, inspect and decontaminate infested vessels. ${ }^{109}$ In 2002, Queensland authorities imposed a quarantine on movement of vessels in and out of Cairns harbor. Since the quarantine was lifted, mussels have been found only on surfaces that support heavy to moderate fouling. ${ }^{110}$ Monitoring will continue to ensure rapid detection of Asian green mussels.

\section{Caribbean tubeworm (Hydroides sanctaecrucis)}

The Caribbean tubeworm (Hydroides sanctaecrucis) was introduced to Cairns harbor and other Australian ports and marinas through ship fouling or ballast water. ${ }^{111}$ It builds calcareous (coral-like) tubes on boat hulls that can reduce vessel speed and increase fuel consumption. Maintenance costs increase due to the need for frequent cleaning of hulls fouled by this tubeworm. $^{112}$

\section{European Featherduster Worm (Sabella spallanzanii)}

The European featherduster worm (Sabella spallanzanii) was probably introduced into Australia on boat hulls. It forms large mats that smother other marine life and competes for food with native species. In Port Philip Bay near Melbourne, Australia, it poses a major threat to the local scallop industry, which is worth an estimated US\$11 million annually. 113

\section{ECHINODERMS}

Echinoderms include seastars, sea urchins, sand dollars and sea cucumbers.

\section{Northern Pacific Seastar (Asterias amurensis)}

The Northern Pacific seastar (Asterias amurensis) is found in Tasmania. First transported to Australia in ballast water, it has spread to Port Phillip Bay via ship hulls. It has a gluttonous appetite for "mussels, snails, fish, crabs, barnacles, worms, sea urchins, sea cucumbers, brittle-stars, ascidians, other sea stars, even drowned dogs," and farmed scallops. The Northern Pacific seastar has caused the near extinction of native Australian species, such as the spotted handfish (Brachionichthys hirsutus), and the near disappearance of bivalve shellfish, including commercially-grown oysters. ${ }^{114}$

\section{New Zealand}

Biosecurity is a significant issue in New Zealand. At least 66 invasive species introductions, some from hull cleaning, were recorded in Auckland's Waitemata Harbour. ${ }^{115}$ Hull cleaning is also considered a possible introduction vector for the bryozoan Watersipora arcuata, which was first noted in New Zealand in 1957. ${ }^{116}$

The New Zealand Ministry of Fisheries has listed six, unwanted AIS: Mediterranean fanworm (Sabella spallanzanii), European green crab (Carcinus maenas), northern Pacific seastar (Asterias amurensis), 
Chinese mitten crab (Eriocheir sinensis), green seaweed (Caulerpa taxifolia) and the Asian clam (Potamocorbula amurensis). They have not yet been recorded in New Zealand waters but would present major ecological and economic threats if they were to become established. ${ }^{117} 118$

Approximately 159 non-native organisms occur in New Zealand's oceans. ${ }^{119} \mathrm{New}$ Zealand's involvement in international trade and the importance of fishing to the indigenous Maori population reflect the ocean's significance to this nation. ${ }^{120}$ Although New Zealand has taken action to mitigate effects of non-indigenous species, the problem of hull-borne, AIS persists.

\section{Asian paddle crab (Charybdis japonica)} The Asian paddle crab (Charybdis japonica) is originally from Japan, Malaysia, and Korea. It was first found in New Zealand in 2000. The Ministry of Fisheries believes that the paddle crab will compete with native crabs and harm the shellfish industry. The New Zealand government believes that the crab was transported from Asia via ship hulls or ballast water discharges. ${ }^{121}$

\section{References}

\footnotetext{
${ }^{1}$ Pimentel, D., L. Lach, R. Zuniga and D. Morrison. 2000. Environmental and Economic Costs of Nonindigenous Species in the United States. BioScience 50 (1).

${ }^{2}$ Grosholz, E.D., G.M. Ruiz, C.A. Dean, K A. Shirley, J.L. Maron and P.G. Connors. 2000. The impacts of a non-indigenous marine predator in a California bay. Ecology 81 (5): 2106-1224.

${ }^{3}$ Cohen, A.N. and J.T. Carlton. 1995. Nonindigenous Aquatic Species in a United States Estuary: A Case Study of the Biological Invasions of the San Francisco Bay and Delta. United States Fish and Wildlife Service, Washington D.C. and The National Sea Grant College Program, Connecticut Sea Grant.

${ }^{4}$ Falkner, M., L. Takata and S. Gilmore. 2005. Report on the California Marine Invasive Species
}

Program. Produced by the California State Lands Commission, Marine Facilities Division for the California State Legislature.

${ }^{5}$ Cohen, A.N. and P.B. Moyle. 2004. Summary of Data and Analyses Indicating that Exotic Species have Impaired the Beneficial Uses of Certain California Waters. A Report Submitted to the State Water Resources Control Board.

${ }^{6}$ Heimowitz, Paul. United States Fish and Wildlife Service, Portland, OR. Personal communication. January 19, 2006.

${ }^{7}$ Cohen, A.N. 2004. Invasions in the sea. National Park Service: Park Science 22(2).

${ }^{8}$ Cohen, A.N. 2004. Invasions in the sea. National Park Service: Park Science 22(2).

${ }^{9}$ Hoppe, K.N. 2002. 'Teredo Navalis - The Cryptogenic Shipworm' In Invasive Aquatic Species of Europe: Distribution, Impacts and Management, E. Leppakoski, S. Gollasch, and S. Olenin (eds.), 116-119. The Netherlands: Kluwer.

${ }^{10}$ Cobb, K. 2002. Return of a Castaway-The Gripping Story of a Boring Clam. Science News 162(5):72.

${ }^{11}$ Alaya, A.M. 2004. Shipworms, Gribbles Devour Bulkheads at Alarming Rate. Star Ledger. http://www.njscuba.net/biology/sw_inverts.html Accessed August 16, 2005.

${ }^{12}$ Cobb, K. 2002. Return of a Castaway-The Gripping Story of a Boring Clam. Science News 162(5): 72.

${ }^{13}$ Cobb, K. 2002. Return of a Castaway-The Gripping Story of a Boring Clam. Science News 162(5): 72.

${ }^{14}$ Hill, C.L. and C.A. Kofoid. 1927. Marine Borers and Their Relation to Marine Construction on the Pacific Coast. Being the Final Report of the San Francisco Bay Marine Piling Committee, Prepared Under the Direction of the San Francisco Bay Marine Piling Committee Cooperating with the National Research Council and the American WoodPreservers' Association. San Francisco: San Francisco Bay Marine Piling Committee.

${ }^{15}$ Cohen, A.N. and J.T. Carlton. 1995. Nonindigenous species in a United States Estuary: A case study of the biological invasions of the San Francisco Bay and Delta. Report of the United States Fish and Wildlife Service, Washington DC and the National Sea Grant College Program Connecticut Sea Grant. CONN-T-95-002.

${ }^{16}$ Cohen, Andrew N. 2004. Invasions in the Sea. Park Science 22 (Fall): 37-41.

${ }^{17}$ Heimowitz, Paul. United States Fish and Wildlife Service, Portland, OR. Personal communication. January 19, 2006. 
${ }^{18}$ No author listed. Popular Mechanics. 1991. Zebras Are Coming. February, 115.

${ }^{19} 100^{\text {th }}$ Meridian Initiative.

http://www.100thmeridian.org/about100mi.htm

Accessed August 3, 2005.

${ }^{20}$ Minchin, D., F. Lucy, and M. Sullivan. 2002.

Zebra Mussel: Impacts and Spread. Invasive Aquatic

Species of Europe. Distribution, Impacts and

Management. Leppäkoski, E. and S. Gollasch, and S.

Olenin (eds). Dordrecht: Kluwer Academic

Publishers.

${ }^{21}$ Raaymakers, S. 2002. The Ballast Water Problem: Global Ecological, Economic, and Human Health Impacts. Paper Presented at the RECSO/IMO Joint Seminar on Tanker Ballast Water Management \& Technologies Dubai, UAE 16-18 Dec 2002.

${ }^{22}$ Minchin, D., F. Lucy, and M. Sullivan. 2002. Zebra Mussel: Impacts and Spread. In Invasive Aquatic Species of Europe. Dirstribution, Impacts and Management. Leppäkoski, E. and S. Gollasch, and S. Olenin (eds). Dordrecht: Kluwer Academic Publishers.

${ }^{23}$ The Log. Reader Poll-How Will Rising Gas Prices Affect Your Labor Day Boating Plans?

http://www.thelog.com/news/newsview.asp?c=15073 7 Accessed August 18, 2005.

${ }^{24}$ Elkhorn Slough National Estuarine Research Reserve, "Least Wanted Aquatic Invaders," http://www.elkhornslough.org/research/aquaticinvade rs/aquatic6.htm Accessed September 7, 2005.

${ }^{25}$ Meacham, P. 2001. Washington State Aquatic Nuisance Species Management Plan. Washington Department of Fish and Wildlife for the Washington Aquatic Nuisance Species Coordinating Committee. ${ }^{26}$ Cohen, A.N. 2005. Guide to the Exotic Species of San Francisco Bay. San Francisco Estuary Institute, Oakland, CA. http://www.exoticsguide.org Accessed August 30, 2005.

${ }^{27}$ Raaymakers, S. 2002. The Ballast Water Problem: Global Ecological, Economic, and Human Health Impacts. Paper Presented at the RECSO/IMO Joint Seminar on Tanker Ballast Water Management \& Technologies Dubai, UAE 16-18 Dec 2002.

${ }^{28}$ Ruiz, G.M. 1987. Interactions among shoregircs, crab, and their invertebrate prey populations. Ph.D. dissertation. University of California, Berkeley. ${ }^{29}$ Gunderson, D.R., D.A. Armstrong, S. Yun-Bing, and R. McConnaughey. 1990. Patterns of estuarine use by juvenile English sole (Parophys vetulus) and Dingeness crab (Cancer magister). Estuaries 13:5971.

${ }^{30}$ Grosholz, E.D. and G.M. Ruiz. 1995. The spread and potential impact of the recently introduced European green crab, Carcinus maenas, in central California. Marine Biology 122:239-247.
${ }^{31}$ Grosholz, E.D., G.M. Ruiz, C.A. Dean, K.A. Shirley, J.L. Maron and P.G. Connors. 2000. The impacts of a non-indigenous marine predator in a California bay. Ecology 81 (5): 2106-1224.

${ }^{32}$ Grosholz, E. 1996. Single trophic level impacts of an introduced predator (European green crab) in a diverse marine food web. From Workshop proceedings: Marine and aquatic non-indigenous species in California: An assessment of current status and research needs. Sponsored by the California Sea Grant College System. San Francisco, CA. October 18-19, 1996. Report No. T-043.

${ }^{33}$ Cohen, A.N. 2005 Guide to the Exotic Species of San Francisco Bay. San Francisco Estuary Institute, Oakland, CA. http://www.exoticsguide.org Accessed August 30, 2005.

${ }^{34}$ Meacham, P. 2001. Washington State Aquatic Nuisance Species Management Plan. Washington Department of Fish and Wildlife for the Washington Aquatic Nuisance Species Coordinating Committee. ${ }^{35}$ Bax, N., A. Williamson, M. Aguero, E. Gonzalez, and W. Geeves. 2003. Marine invasive alien species: a threat to global biodiversity. Marine Policy 27 (4): 313-323.

${ }^{36}$ Wasson, K., C. Zabin, L. Bedinger, M. Diaz, J. Pearse. 2001. Biological invasions of estuaries without international shipping: the importance of intraregional transport. Biological Conservation 102: 143-153.

${ }^{37}$ Cohen, A.N. and J.T. Carlton. 1995. Nonindigenous Aquatic Species in a United States Estuary: A Case Study of the Biological Invasions of the San Francisco Bay and Delta. United States Fish and Wildlife Service, Washington D.C. and The National Sea Grant College Program, Connecticut Sea Grant. CONN-T-95-002.

${ }^{38}$ Boyd, M. J., T.J. Mulligan and F.J. Shaughnessy. 2002. Non-Indigenous Marine Species of Humboldt Bay. California. A Report to the California Department of Fish and Game. February 28, 2002.

${ }^{39}$ Lambert, C. and G. Lambert. 1998. Nonindigenous ascidians in southern California harbors and marinas. Marine Biology 130: 685.

${ }^{40}$ National Introduced Marine Pest Information System, "Botryllus schlosseri," http://www.marine.csiro.au/crimp/nimpis/spImpact.a sp?txa=6854 Accessed August 23, 2005.

${ }^{41}$ Guide to the Exotic Species of San Francisco Bay, "Botryllus schlosseri,"

http://www.exoticsguide.org/species_pages/b_schloss eri.html Accessed August 30, 2005.

${ }^{42}$ Aquaculture Association of Nova Scotia, "Tunicates Affecting the Nova Scotia Shellfish Industry,” 
http://www.aansonline.com/r\&d/tunicateseffecting.pd f Accessed: November 1, 2005.

${ }^{43}$ Lambert, C. and G. Lambert. 1998. Nonindigenous ascidians in southern California harbors and marinas. Marine Biology 130: 684.

${ }^{44}$ Sea Grant Non-indigenous Species Site, "Status and Impacts of Marine Alien Species in South Africa," http://sgnis.org/publicat/grifrobi.htm Accessed: August 23, 2005.

${ }^{45}$ Aquaculture Association of Nova Scotia, "Tunicates Affecting the Nova Scotia Shellfish Industry,"

http://www.aansonline.com/r\&d/tunicateseffecting.pd f Accessed: November 1, 2005.

${ }^{46}$ Lambert, C. and G. Lambert. 1998. Nonindigenous ascidians in southern California harbors and marinas.Marine Biology 130: 684.

${ }^{47}$ National Introduced Marine Pest Information System, "Styela clava," http://www.marine.csiro.au/crimp/nimpis/spImpact.a sp?txa=6836 $>$ Accessed August 23, 2005.

${ }^{48}$ Guide to the Exotic Species of San Francisco Bay, "Styela clava,"

http://www.exoticsguide.org/species_pages/s_clava.h tml Accessed: August 30, 2005.

${ }^{49}$ Aquaculture Association of Nova Scotia, "Tunicates Affecting the Nova Scotia Shellfish Industry," http://www.aansonline.com/r\&d/tunicateseffecting.pd f Accessed: November 1, 2005.

${ }^{50}$ Culver, C.S. and A.M. Kuris. 2004. Susceptibility of California gastropods to an introduced South African sabellid polychaete Terebrasabella heterouncinata. Invertebrate Biology 123(4): 316.

${ }^{51}$ Bastida-Zavala, Rolando J. and Harry A. Ten Hove. 2003. Revision of Hydroides Gunnerus, 1768 (Polychaeta: Serpulidae) from the Eastern Pacific Region and Hawaii. Beaufortia 53 (4): 68.

${ }^{52}$ Bastida-Zavala, Rolando J. and Harry A. Ten Hove. 2002. Revision of Hydroides Gunnerus, 1768 (Polychaeta: Serpulidae) from the Western Atlantic Region. Beaufortia 52 (9):164.

${ }^{53}$ CSIRO Marine Research, "Marine Pest Information Sheet: Hydroides sanctaecrucis," http://www.marine.csiro.au/crimp/Reports/Infosht15_ Hydroides.pdf Accessed September 8, 2005.

${ }^{54}$ Bastida-Zavala, Rolando J. and Harry A. Ten Hove. 2002. Revision of Hydroides Gunnerus, 1768 (Polychaeta: Serpulidae) from the Western Atlantic Region. Beaufortia 52 (9):167.

${ }^{55}$ Bastida-Zavala, Rolando J. and Harry A. Ten Hove. 2003. Revision of Hydroides Gunnerus, 1768 (Polychaeta: Serpulidae) from the Eastern Pacific Region and Hawaii. Beaufortia 53 (4):87.
${ }^{56}$ CSIRO Marine Research, "Marine Pest Information Sheet: Hydroides sanctaecrucis," http://www.marine.csiro.au/crimp/Reports/Infosht15_ Hydroides.pdf Accessed September 8, 2005.

${ }^{57}$ Bastida-Zavala, Rolando J. September 23, 2005. Personal communication.

${ }^{58}$ Elkhorn Slough National Estuarine Research Reserve, "Least Wanted Aquatic Invaders" http://www.elkhornslough.org/research/aquaticinvade rs/aquatic5.htm Accessed July 5, 2005.

${ }^{59}$ Elkhorn Slough National Estuarine Research Reserve, "Least Wanted Aquatic Invaders," http://www.elkhornslough.org/research/aquaticinvade rs/aquatic21.htm Accessed September 8, 2005.

${ }^{60}$ Don Schulz. 2005. Surfrider Foundation Huntington/Seal Beach Chapter, personal communication.

${ }^{61}$ Cohen, A., L. Harris, B. Bingham, J. Carlton, J. Chapman, C. Lambert, G. Lambert, J. Ljubenkov, S. Murray, L. Rao, K. Reardon and E. Schwindt. 2002. A Rapid Assessment Survey of Exotic Species in Sheltered Coastal Waters. For the California Department of Fish and Game, Sacramento, CA, the State Water Resources Control Board, Sacramento, $\mathrm{CA}$ and the National Fish and Wildlife Foundation, San Francisco, CA.

${ }^{62}$ Elkhorn Slough National Estuarine Research Reserve, "Least Wanted Aquatic Invaders," http://www.elkhornslough.org/research/aquaticinvade rs/aquatic6.htm Accessed July 5, 2005.

${ }^{63}$ Cohen, Andrew N. 2005. Guide to the Exotic Species of San Francisco Bay. San Francisco Estuary Institute, Oakland, CA, www.exoticsguide.org ${ }^{64}$ Boyd, M.J., T.J. Mulligan and F.J. Shaughnessy. 2002. Non-indigenous Marine Species of Humboldt Bay, California. Appendix C in: Report to the Legislature: A Survey of Non-Indigenous Aquatic Species in the Coastal and Estuarine Waters of California, M.E. Ashe (ed.), California Department of Fish and Game, Office of Oil Spill Prevention and Response, Sacramento, CA. p. 50.

${ }^{65}$ Mawatari, S. 1952. On Watersipora cucullata (Busk) I. Systematic study. Miscellaneous Reports of the Tokyo Research Institute of Natural Resources 25:14-17.

${ }^{66}$ Aguilar-Rosas, Luis E. and Raul. 2004. The Marine Algae Undaria pinnatifida Invades Baja California Coast. Bight Bulletin (8): 1.

${ }^{67}$ Commonwealth Scientific and Industrial Research Organization. 1998. Introduced Marine Pests. CSIRO Marine Research Information Sheet No. 2. http://www.csiro.au/index.asp?type=faq\&id=Introduc edMarinePests\&stylesheet=sectorInformationSheet Accessed August 29, 2005. 
${ }^{68}$ Raaymakers, S. 2002. The Ballast Water Problem: Global Ecological, Economic, and Human Health Impacts. Paper Presented at the RECSO/IMO Joint Seminar on Tanker Ballast Water Management \& Technologies Dubai, UAE 16-18 December 2002.

${ }^{69}$ Global Invasive Species Database. Ecology of Undaria Pinnatifida Invasive Species Specialist Group (ISSG) of the IUCN Species Survival Commission http://www.invasivespecies.net/database/species/ecol ogy.asp?si $=68 \& f r=1 \&$ sts $=$ Accessed November 1 , 2005.

${ }^{70}$ Fuller, P. 2001. Non-indigenous aquatic species in the United States. Workshop Proceedings:

Preventing the Introduction and Spread of Aquatic Invasive Species in North America, March 28-30. Publication prepared by the Secretariat of the Commission for Environmental Cooperation. Jamie Reaser (ed).

${ }^{71}$ Oregon Invasive Species Council. 2005. Invasive Species in Oregon Report Card, 2004.

72 The $100^{\text {th }}$ Meridian Initiative. 2004. Zap the Zebra. Brochure.

${ }^{73}$ Geller, J.B. 1999. Decline of a native mussel masked by sibling species invasion. Conservation Biology 13:661-664.

${ }^{74}$ Apte, S., B.S. Holland, L.S. Godwin, and J.P.S. Gardner. 2000. Jumping ship: a steeping stone event mediating transfer of a non-indigenous species via a potentially unsuitable environment. Biological Invasions 2:75-79.

${ }^{75}$ Rayski, C., and E. A. Garden. 1961. Life-cycle of an acanthocephalan parasite of the eider duck.

Nature. London. 92:185-186.

${ }^{76}$ Cohen, A.N. 2005 Guide to the Exotic Species of San Francisco Bay.

San Francisco Estuary Institute, Oakland, CA, http://www.exoticsguide.org Accessed August 30, 2005.

77 Sytsma, M. 2004. Oregon Invasive Species Action Plan. Oregon Invasive Species Council.

${ }^{78}$ Rogers, R. 2001. The green menace: the European green crab. Environmental Practice 3(2):93-95.

${ }^{79}$ Rogers, R. 2001. Alien invader: the European green crab. Presentation given at Nisqually Wildlife Refuge, WA, on August 29, 2001.

${ }^{80}$ Report of the Commissioner of the Environment and Sustainable Development. Office of the Auditor General of Canada. "The green crab is eating its way up Canada's coasts." http://www.oag-

bvg.gc.ca/domino/reports.nsf/html/c20021004se05.ht $\mathrm{ml}$ Accessed November 1, 2005.

${ }^{81}$ Harrell, D.C. 2004. Invading Sea Squirts are

'Sliming' the Sound. Seattle Post Intelligencer,
October 12, 2004.

http://woodshole.er.usgs.gov/project-

pages/stellwagen/didemnum/images/pdf/news/seattle. pdf Accessed August 302005.

${ }^{82}$ Pacific Northwest Cuba. Invasive Tunicate! (Didemnum cf. lahillei) in the Pacific Northwest. http://woodshole.er.usgs.gov/project-

pages/stellwagen/didemnum/images/pdf/news/pnwsc uba.pdf Accessed August 302005.

${ }^{83}$ Washington Department of Fish and Wildlife.

2004. Quick Response Planned to Stop Spread of Invasive Marine Life Found Off Edmonds. News Release, October 8, 2004.

http://woodshole.er.usgs.gov/project-

pages/stellwagen/didemnum/images/pdf/news/news release.pdf Accessed August 302005.

${ }^{84}$ Sheets, B. 2004 . Sea Squirt Invades Dive Park-

Officials Are Trying to Kill the Species Found in

Edmonds. Herald Net, October 13, 2004.

http://woodshole.er.usgs.gov/project-

pages/stellwagen/didemnum/images/pdf/news/edmon ds.pdf Accessed August 30, 2005.

${ }^{85}$ US Geological Survey. Didemnum sp. -

Washington Coast Occurrences and Images.

http://woodshole.er.usgs.gov/project-

pages/stellwagen/didemnum/images/pdf/wash1.pdf Accessed August 302005.

${ }^{86}$ Apte, S., B.S. Holland, L.S. Godwin, and J.P.S. Gardner. 2000. Jumping ship: a stepping stone event mediating transfer of a non-indigenous species via a potentially unsuitable environment. Biological Invasions 2: 75-79.

${ }^{87}$ Geller, J.B. 1999. Decline of a native mussel masked by sibling species invasion. Conservation Biology 13: 661-664.

${ }^{88}$ Godwin, Scott. Bishop Museum, Honolulu, HI. Personal communication Jnuary 23, 2006

${ }^{89}$ Shluker, A. State of Hawaii Aquatic Invasive Species Management Plan. 2003. Department of Land and Natural Resources, Division of Aquatic Resources.

http://www.hawaii.gov/dlnr/dar/pubs/ais_mgmt_plan final.pdf Accessed November 1, 2005.

${ }^{90}$ Shluker, A. State of Hawaii Aquatic Invasive Species Management Plan. 2003. Department of Land and Natural Resources, Division of Aquatic Resources.

http://www.hawaii.gov/dlnr/dar/pubs/ais_mgmt_plan final.pdf Accessed November 1, 2005.

${ }^{\overline{91}}$ Fuller, P. 2001. Non-indigenous aquatic species in the United States. Workshop Proceedings:

Preventing the Introduction and Spread of Aquatic Invasive Species in North America, March 28-30. Publication prepared by the Secretariat of the 
Commission for Environmental Cooperation. Jamie Reaser (ed.), 86.

${ }^{92}$ Percy, J.A. 2003. Alien invasions: Introduced species in the Bay of Fundy. Bay of Fundy Ecosystem Partnership. SeaPen Communications, Granville Ferry. Nova Scotia. Supported by: The Environmental Conservation Branch Environment Canada - Atlantic Region Dartmouth, Nova Scotia and Department of Fisheries and Oceans ScotiaFundy Region. http://www.bofep.org/alien_species.htm Accessed September 1, 2005

${ }^{93}$ Ruiz GM, P Fofonoff, AH Hines, \& ED Grosholz. 1999. Non-indigenous species as stressors in estuarine and marine communities: Assessing impacts and interactions. Limnology

and.Oceanography 44 (3, part 2).

${ }^{94}$ Whitlatch, R.B. 2004. Recreational hull fouling research.

http://www.marinesciences.uconn.edu/teamb/Pages/T eam\%20Benthos.htm Accessed September 1, 2005

${ }_{95}$ Alaya, A. M. 2004. Shipworms, Gribbles Devour Bulkheads at Alarming Rate. Star Ledger. http://www.njscuba.net/biology/sw_inverts.html Accessed August 162005.

${ }^{96}$ Alaya, A. M. 2004. Shipworms, Gribbles Devour Bulkheads at Alarming Rate. Star Ledger. http://www.njscuba.net/biology/sw_inverts.html Accessed August 16, 2005.

${ }^{97}$ Behrend, D.W. Worms Won't Munch Plastic Pier. http://www.columbia.edu/cu/bb/oldstuff/bb0213.30.h tml Accessed August 16, 2005.

${ }^{98}$ ACT Composite Timbers. Featured ACT Installation-Tiffany Street Pier, New York. http://www.compositetimbers.com/tiff_street_pier.ht ml Accessed August 17, 2005.

${ }^{99}$ Beck, R. 2000. 'Termites of the Sea' Threaten Pilings, Docks. Boothbay Register. http://boothbayregister.maine.com/2000-1019/shipworm threat.html Accessed August 29, 2005.

${ }^{100}$ Cobb, K. 2002. Return of a Castaway-The gripping story of a boring clam. Science News 162 (5): 72.

${ }^{101}$ U.S. Environmental Protection Agency. 2000. An Initial Survey of Aquatic Invasive Species Issues in the Gulf of Mexico Region. Version 4.0. Table 5. EPA 855-R-00-003. September 2000.

${ }^{102}$ Fuller, P. 2001. Non-indigenous aquatic species in the United States. Workshop Proceedings:

Preventing the Introduction and Spread of Aquatic Invasive Species in North America, March 28-30.

Publication prepared by the Secretariat of the Commission for Environmental Cooperation. Jamie Reaser (ed.), 86.
${ }^{103}$ Brandt, S.B. 2003. Written Testimony before the Subcommittee on Fisheries Conservation, Wildlife, and Oceans and the Subcommittee on National Parks, Recreation, and Public Lands. House Resource Committee. April 29, 2003. Dr. Brandt is the Director of the Great Lakes Environmental Research Laboratory.

${ }^{104}$ Brandt, S.B. 2003. Written Testimony before the Subcommittee on Fisheries Conservation, Wildlife, and Oceans and the Subcommittee on National Parks, Recreation, and Public Lands. House Resource Committee. April 29, 2003. Dr. Brandt is the Director of the Great Lakes Environmental Research Laboratory.

${ }^{105}$ Ferguson, R. 2000. The effectiveness of Australia's response to the Black Striped Mussel incursions in Darwin, Australia. A Report of the Marine Pest Incursion Management Workshop August 27-28 1999. Research report produced by the Department of Environment and Heritage.

${ }^{106}$ Marshall, A.J., H. N. Cribb, and M. J. Thompson. 2003. Exotic marine pests: what is being done about preventing their introduction. Darwin Harbour Plan of Management Workshop Presentation.

${ }^{107}$ Reef Research Center. 2004. Introduced species in tropical waters: Current state of knowledge. CRC Reef Research Centre Ltd.

${ }^{108}$ Goggin, L. 2004. Introduced species in tropical waters: Current state of knowledge. CRC Reef Research Centre Ltd.

${ }^{109}$ CRC Reef Research Centre. 2004. Introduced Species in Tropical Waters: Current State of Knowledge. Australia: CRC Reef Research Centre Ltd.

${ }^{110}$ Hayes, K., C. Sliwa, S. Migus, F. McEnnulty, and P. Dunstan. 2005. National priority pests: Part II Ranking of Australian marine pests. An independent report undertaken for the Department of Environment and Heritage by CSIRO Marine Research. ${ }^{111}$ CRC Reef Research Centre. 2004. Introduced Species in Tropical Waters: Current State of Knowledge. Australia: CRC Reef Research Centre Ltd.

${ }^{112}$ CSIRO Marine Research, "Marine Pest Information Sheet: Hydroides sanctaecrucis," http://www.marine.csiro.au/crimp/Reports/Infosht15_ Hydroides.pdf Accessed September 8, 2005.

${ }^{113}$ Bonny, M. 1995. "Preventing the invasion of marine immigrants”, Search 26 (3): 81.

${ }^{114}$ Invasive Species Council. 2003. The Inquiry Into the Regulation, Control and Management of Invasive Species and the Environment Protection and Biodiversity Conservation Amendment (Invasive Species) Bill 2002. 
${ }^{115}$ Hayward, B.W., A.B. Stephenson, and J.L Morley. 1997. Faunal changes in Waitemata Harbour sediments, 1930s-1990s. Journal of the Royal Society of New Zealand 27: 1-20.

${ }^{116}$ McClary, D.J. and R.J. Nelligan. 2001. Alternate Biosecurity Management Tools for Vector Threats: Technical Guidelines for Acceptable Hull Cleaning Facilities. Prepared for Ministry of Fisheries by Kingett Mitchell \& Associates Ltd., September 2001. ${ }^{117}$ Mountfort, D.O. 1998. Current status of ballast water treatment research at Cawthron Institute, Nelson, New Zealand. Report prepared for Australian Quarantine and Inspection Services (AQIS), Canberra, Australia. Cawthron Report No. 446.

${ }^{118}$ Biosecurity Council. 2003. Protect New Zealand: the biosecurity strategy for New Zealand.

Wellington, Biosecurity Council, 63.

${ }^{119}$ National Institute of Water and Atmospheric Research (NIWA). 2000. Vessel Hulls: Continuing Vectors of Exotic Marine Organisms. Biodiversity Update Online. http://www.niwa.cri.nz/pubs/bu/01/hulls.htm Accessed August 19, 2004.

${ }^{120}$ Hewitt C.L., J. Willing, A. Bauckham, A.M. Cassidy, C.M.S. Cox, L. Jones, and D.M. Wotton. 2004. New Zealand marine biosecurity: delivering outcomes in a fluid environment. New Zealand Journal of Marine and Freshwater Research 38: 429438.

${ }^{121}$ New Zealand Ministry of Fisheries. 2002. Marine Biosecurity Fact Sheet.

http://www.fish.govt.nz/sustainability/biosecurity/pes ts/charybdis_fact_sheet.pdf Accessed August 31, 2005. 


\section{Aquatic Invasive Species Transported by Other Means and Their Impacts}

This section of the report will discuss selected examples of aquatic invasive species (AIS) that have been introduced to various regions by means other than hull fouling. Some are freshwater species. They illustrate the potential severity of aquatic bioinvasion impacts and costs to control or eradicate them. Research may discover yet more AIS vectors in coming years.

\section{BACTERIA}

\section{Cholera (Vibrio cholerae)}

Cholera (Vibrio cholerae) bacteria causes the deadly disease cholera and can be transported via ships' ballast water. It is the vector responsible for the cholera epidemic that began in Peru in 1991 and eventually spread through much of South America, killing 10,000 people and affecting many more. This strain previously was only known to have existed in Bangladesh. ${ }^{1}$

Vibrios are one of the most common organisms in surface waters of the world. They occur in marine and freshwater and in associations with aquatic animals. ${ }^{2} \mathrm{~A}$ few species are human pathogens, including $V$. cholerae, $V$. parahemolyticus and $V$. vulnificus. A particular strain of $V$. cholerae has become endemic in the Gulf of Mexico. ${ }^{3}$ Several people in the United States have contracted cholera after eating raw or undercooked shellfish from the Gulf of Mexico. This form of cholera is usually characterized by diarrhea and/or vomiting. Infections usually occur in individuals with increased susceptibility to infections. ${ }^{4}$

\section{MOLLUSCS}

\section{Japanese Oyster Drill (Ceratostoma inornatum)}

The Japanese oyster drill (Ceratostoma inornatum) is an invasive gastropod (snaillike mollusc). ${ }^{5}{ }^{6}$ Ceratostoma inornatum was introduced to the Pacific Northwest and British Columbia when Pacific oysters were imported from Japan in the early 1900s. ${ }^{7} 9$

Since then, it has been known to prey on the native Olympia oyster industry, as well as the introduced Pacific oyster, both of which are commercially important species. ${ }^{10} 11$ The oyster drill bores holes into the shells of infant oysters to consume the meat. In Washington, "25\% mortality occurs in outplanted oyster seed, production costs increase by nearly $20 \%$, and net profits decrease by as much as $55 \%$ due to drill predation." 1213

\section{Asian Clam (Potamocorbula amurensis)}

The Asian clam (Potamocorbula amurensis), introduced to San Francisco Bay in 1986, rapidly filters plankton from the water for its food. The most apparent impact of this invasive species has been the disappearance of the summer phytoplankton bloom in the northern part of the bay. With the decrease in phytoplankton have come declines in populations of several species that feed on them and that in turn are important food sources for larval and adult fish. ${ }^{14}$ The Asian clam now reaches densities of over $10,000 / \mathrm{m}^{2}$ in San Francisco Bay and has been blamed for the collapse of local fisheries. ${ }^{15}$

\section{Asian Freshwater Clam (Corbicula fluminea)}

The Asian freshwater clam (Corbicula fluminea) has plugged condenser tubes at the Central Valley Project pump and clogged underground pipes, turnout valves, laterals and sprinkler systems throughout California. 
Blue catfish were introduced to control it, but this effort was largely unsuccessful. ${ }^{16}$

\section{New Zealand Screwshell (Maoricolpus roseus)}

The New Zealand screwshell (Maoricolpus roseus) was introduced to Tasmania from New Zealand in the 1920s and has spread across the Australian continental shelf as far north as Sydney. Abundant screwshell populations change the seabed habitat by covering soft sediments with their hard shells, providing attachment points for other marine fauna including the invasive seaweed Undaria pinnatifida. Once screwshells die, their empty shells provide homes for hermit crabs, further changing the food web. ${ }^{17}$

\section{New Zealand Mudsnail (Potamopyrgus antipodarum)}

The New Zealand mudsnail (Potamopyrgus antipodarum) is a small aquatic snail native to freshwater lakes and streams of New Zealand. In the United States it was first detected during the mid-1980s in the Snake River region of Idaho. Since then, it has spread to waters of California, Arizona, Oregon, Utah, Montana and Wyoming, including Yellowstone National Park. ${ }^{18}$

Mudsnails may affect the food chain of native trout, as well as physical characteristics of the streams, because they can reproduce quickly and reach high densities. Mudsnails can withstand dessication and a variety of temperature regimes They are small enough that anglers, swimmers, pets and other water users could inadvertently transport them. ${ }^{19}$

\section{CRUSTACEANS}

Chinese Mitten Crab (Eriocheir sinensis) The Chinese mitten crab (Eriocheir sinensis) is native to coastal rivers and estuaries of Korea and China along the Yellow Sea and is named for the patches of dense "hairs" on the claws of adult species. ${ }^{20}$ It may have been introduced to California to establish a fishery or accidentally released from ships' ballast water. $^{21}$ The mitten crab was introduced to San Francisco Bay in the late 1980s or early 1990 s $^{22}$ and by 1998 was widely distributed in the Sacramento-San Joaquin Delta and the Central Valley. ${ }^{23}$

The mitten crab poses several economic and ecological threats to the San Francisco estuary. In tidal areas, mitten crabs burrow into banks during low tide for protection from predators. Burrow densities in South Bay creeks are as high as three per square foot with most burrows up to eight to twelve inches deep. Their burrows can accelerate erosion and reduce levee stability. Mitten crab activity threatens the extensive levee system that protects agricultural fields and communities in the Sacramento-San Joaquin Delta. ${ }^{24}$ In the mitten crab's native Korea and China, juveniles have been reported to damage rice crops by consuming young shoots and burrowing in the rice field levees. $^{25}$

If the mitten crab spreads into the Sacramento-San Joaquin watershed, it could threaten water pumping facilities and aqueducts as well as disrupt fresh water flow to Southern California by blocking filters. ${ }^{26}$ Mitten crabs or their shells have "clogged intake screens, pipes, condensers or valves at one wastewater treatment plan and two power plants in California, reducing power plant cooling flows."27 28

Commercial and recreational fishing operations have been affected by mitten crabs that steal bait and damage nets, causing loss of catch. For example in South San Francisco Bay, commercial shrimp trawlers must remove crabs from their nets. Mitten crabs' appendages can cut fishing 
nets, thereby decreasing the catch and requiring costly repairs. ${ }^{29}$

The Chinese mitten crab also poses a human health risk. It carries a parasite called the lung fluke, which can injure the lung or the brain, if the crab is eaten uncooked or undercooked. $^{30} 31$

Three invasive species of crayfish also cause erosion and damage maritime equipment: Orconectes virilis, Procambarus clarki, and Pacifastacus leniusculus. ${ }^{32}$

\section{Virilis crayfish (Orconectes virilis)}

The North American native range of the virilis crayfish (Orconectes virilis) extends from Alberta to Quebec, Canada, ${ }^{33}$ and in the United States from Montana and Utah southeast to Arkansas, north to the Great Lakes, and east to New York. It is invasive in the United States in parts of the Southwest, Southeast, Mid-Atlantic, and the Northeast $^{34}$ as well as in Chihuahua, Mexico. ${ }^{35}$ Burrows of $O$. virilis in ditches and levee banks may disrupt irrigation networks. The crayfish's burrowing and swimming activities may muddy the water, reducing photosynthesis in submerged plants. Harvested grain may be contaminated as soil is forced out of crayfish burrows, suspended as the field is drained, and picked up by harvesting machinery. Furthermore, the virilis crayfish eats rice seeds and seedlings and its digging uproots seedlings. ${ }^{36}$

\section{Red crayfish (Procambarus clarki)}

The red crayfish (Procambarus clarki) is native to bayous of the southeastern United States but is invasive in the southwestern United States. For example, in the Santa Catalina Mountains near Tucson, Arizona it is common in most drainages with permanent water, such as the biologically diverse Sabino Canyon. The red crayfish feeds on plant material and competes for the substrates on which endangered or threatened species, such as Sonoran Desert fishes, lay their eggs. ${ }^{37} 38$

\section{Signal crayfish (Pacifastacus leniusculus)} Although the signal crayfish (Pacifastacus leniusculus) prefers to feed on animals, it will also eat plants. ${ }^{39}$ It can have a considerable impact on populations of macro-invertebrates, benthic fish, and aquatic plants. ${ }^{40} 41$

The natural range of $P$. leniusculus extends from the southern part of British Columbia to the northern part of California and east to parts of Utah and Montana. ${ }^{42}$ Fishermen introduced $P$. leniusculus into Central and Southern California's rivers as bait during the 1960's and 1970's. They have become the primary threat to the native and endangered Shasta crayfish (Pacifastacus fortis) as they are about twice their size and compete for food and space. ${ }^{43}$

Pacifastacus leniusculus was introduced from Portland, Oregon into Japan on five occasions between 1926 to 1930, where it has reduced the range of the indigenous Cambaroides japonicus on the island of Hokkaido. $^{44} 45$ In Europe, it has completely displaced populations of the indigenous crayfish species, particularly the whiteclawed crayfish. ${ }^{46} 47$

\section{Cladoceran Water Flea (Cercopagis pengoi)}

The Cladoceran Water Flea (Cercopagis pengoi), originally from the Black and Caspian Seas, was introduced to the Baltic Sea by ships' ballast water. It can reproduce rapidly and quickly dominate zooplankton populations. The water flea can foul fishing nets. This places an economic burden on fishermen, who must invest in cleaning their nets. $^{48}$ 


\section{CTENOPHORES}

Ctenophores are also called comb jellies or sea walnuts. They are related to jellyfish, but lack stinging cells. Comb jellies have an ovoid shape and move by beating rows of tiny hairs, called cilia.

\section{North American Comb Jelly (Mnemiopsis leidyi)}

The North American comb jelly

(Mnemiopsis leidyi) originated on the eastern coast of this continent. It is now found in the Black, Azov and Caspian Seas. It reproduces quickly and can exhaust zooplankton populations on which it feeds. Zooplankton depletion affects other species that feed on them, in turn affecting local fisheries that harvest those species. In the 1990s, the effects of the North American comb jelly decimated entire seafood industries. $^{49}$

\section{SEAWEEDS AND HARMFUL ALGAL BLOOMS}

\section{Invasive Seaweed (Caulerpa taxifolia)}

In contrast to the ative strain of Caulerpa taxifolia, which occurs in tropical U.S. waters, the "aquarium strain" or "aquariumbred clone” is a distinctly different seaweed. It is much larger, more aggressive, and capable of invading both tropical and cooler regions. It has been introduced to the Mediterranean Sea, the Adriatic Sea and the West Coast of the United States. ${ }^{50} 5152$

The invasive, "aquarium strain” of Caulerpa taxifolia was discovered in Agua Hedionda Lagoon of San Diego County and Huntington Harbor of Orange County in Southern California. ${ }^{53}$ Evidence suggests that it was discarded from saltwater aquaria. ${ }^{54}$ Although it was not introduced on boat hulls, Caulerpa can be snagged on fishing and boating equipment and anchors, and fragments can be spread over great distances. $^{55}$

Caulerpa has devastated large areas of the western Mediterranean Sea by blanketing over 10,000 acres of the sea floor and crowding out other species, especially native seaweeds. It contains toxic substances and so has very little nutritional value for animals that normally feed upon the native species it displaces. Thus, a Caulerpa invasion would threaten California's coastal marine life and the fishing and tourism industries that depend upon it. 56575859

This bright green seaweed grows in vast beds. Its stems can extend nine feet and produce up to 200 feather-like branches that can reach a foot in length. ${ }^{60}$ Because $C$. taxifolia can spread quickly by vegetative growth, introductions are taken seriously. ${ }^{61}$ The US\$4.5 million eradication project conducted in Southern California is discussed in Section VIII of this report. "Coral reefs in Florida, the Virgin Islands, Hawaii, American Samoa and Guam, and waters north to North Carolina and California, could be vulnerable to invasion."62 63

\section{Harmful Algal Blooms}

Toxic phytoplankton (microscopic algae), whether they are red, brown or green can multiply rapidly, or "bloom." When this occurs, they may reduce the level of dissolved oxygen in the water or emit toxins, killing other marine life. They may drift ashore in masses and decay, producing strong odors that drive away recreational boaters and fishermen. ${ }^{64}$ During a red tide outbreak in New Zealand, people walking along the shore became ill from airborne toxins. ${ }^{65}$ 


\section{HIGHER PLANTS}

\section{Atlantic Salt Marsh Cord Grass (Spartina alterniflora)}

The Atlantic salt marsh cord grass (Spartina alterniflora) can alter ecosystems and may change sediment dynamics. ${ }^{66}$ It was first reported in Washington State where it converted hundreds of acres of mudflats in Willapa Bay into cord grass islands. It has spread to San Francisco Bay, California, where it is crowding out native cord grass. The plant's dense structure makes it difficult for animals and other plants to coexist. For example algae beneath the cord grass do not receive enough light to reproduce. Various native bird species have been forced out because they require open mudflats that the invasive cord grass has overgrown. ${ }^{67}$

\section{Water Hyacinth (Eichhornia crassipes) \\ Water hyacinth (Eichhornia crassipes),} which grows in ponds, canals, freshwater and coastal marshes, lakes, and backwater sloughs and oxbows along rivers, ${ }^{68}$ has been a problem in the Sacramento-San Joaquin Delta for over a decade. It clogs navigational waterways and fouls water system intakes and pumps. Known as "perhaps the world's most troublesome aquatic weed," water hyacinth is native to South America and has spread to more than 50 countries on five continents. It reproduces "by fragmentation and has the highest reported growth rate for any vascular plant, capable of doubling its biomass in 6-18 days. It can cover the water's surface with mats of living and decaying plant tissue up to two meters thick." 69

\section{Eurasian watermilfoil (Myriophyllum spicatum) and Brazilian waterweed (Egeria densa)}

Eurasian watermilfoil (Myriophyllum spicatum) and Brazilian waterweed (Egeria densa) can be carried by boats. They foul boat propellers and the water intakes of boat engines. They can clog channels and boat berths. ${ }^{70}$

\section{References}

${ }^{1}$ Raaymakers, S. 2002. The Ballast Water Problem: Global Ecological, Economic, and Human Health Impacts. Paper Presented at the RECSO/IMO Joint Seminar on Tanker Ballast Water Management \& Technologies Dubai, UAE 16-18 Dec 2002.

2 Todar, K. 2005. Todar's Online Textbook of Bacteriology. University of Wisconsin-Madison Department of Bacteriology.

http://textbookofbacteriology.net/V.vulnificus.html Accessed November 3, 2005.

${ }^{3}$ Office of Public Health, Louisiana Department of Health and Hospitals. Cholera and other Vibrios. 2004. Infectious Disease Epidemiology Section. http://www.oph.dhh.state.la.us/infectiousdisease/docs /disease_updates_04/8_04_updates/CholeraVibrioMa nual.pdf Accessed November 3, 2005.

${ }^{4}$ Todar, K. 2005. Todar's Online Textbook of Bacteriology. University of Wisconsin-Madison Department of Bacteriology

http://textbookofbacteriology.net/cholera.html Accessed November 3, 2005.

${ }^{5}$ Levings, C. 2005. Research Scientist Fisheries and Oceans Canada, Science Branch, Marine Ecosystem and Aquaculture Division, Centre for Aquaculture and Environmental Research West Vancouver British Columbia, personal communication.

${ }^{6}$ Levings, C., D. Kieser, G. S. Jamieson, and S. Dudas. 2002. Marine and Estuarine Alien Species in the Strait of Georgia, British Columbia. In Alien Invaders in Canada's Waters, Wetlands, and Forests, edited by Renata, C., P. Nantel, and E. Muckle-Jeffs, 111-131. Ottawa: Natural Resources Canada, Canadian Forest Service.

${ }^{7}$ Oregon Aquatic Nuisance Species Management Plan. 2001. Produced by E. Hanson and M. Sytsma. Portland State University.

http://permanent.access.gpo.gov/websites/www.ansta skforce.gov/OR_ANS_Plan.pdf Accessed November 1, 2005.

${ }^{8}$ Hanson, E. and M. Sytsma. 2001. Oregon Aquatic Nuisance Species Management Plan. Portland State University

${ }^{9}$ Levings, C. Kieser, D., Jamieson, G.S. and S. Dudas. marine and estuarine alien species in the Strait of Georgia, British Columbia. In Alien 
Invaders in Canada's Waters, Wetlands, and Forests. Renata, C., P. Nantel, and E. Muckle-Jeffs (eds) 111131. Ottawa: Natural Resources Canada, Canadian Forest Service

${ }^{10}$ Washington Sea Grant Program Office of Marine and Environmental \& Resource Programs University of Washington Seattle. 2000. Draft-Northwest Straits Overview: A Science Gap Report. Prepared for the Northwest Strait Commission.

${ }^{11}$ Gillespie, G. 1999. Status of the Olympia Oyster, Ostrea conchaphila, in Canada. Canadian Stock Assessment Secretariat Research Document 99/150.

12 Elston, R. 1997. Pathways and Management of Marine Nonindigenous Species in the Shared Waters of British Columbia and Washington. Final Report Prepared for the Puget Sound Water Quality Authority U.S. Environmental Protection Agency, Region 10 Department of Fisheries and Oceans, Canada.

${ }^{13}$ Hanson, E. and M. Sytsma. 2001. Oregon Aquatic Nuisance Species Management Plan. Prepared with Support from the Oregon Watershed Enhancement Board and Portland State University.

14 Thompson, J.K. 1996. Impacts of the Asian clam on San Francisco Bay region. From Workshop proceedings: Marine and aquatic non-indigenous species in California: An assessment of current status and research needs. Sponsored by the California Sea Grant College System. San Francisco, CA. October 18-19, 1996. Report No. T-043.

${ }^{15}$ Bax, N., A. Williamson, M. Aguero, E. Gonzalez, and W. Geeves. 2003. Marine invasive alien species: a threat to global biodiversity. Marine Policy 27(4): 313-323.

${ }^{16}$ Cohen, A. and P. Moyle. 2004. Summary of data and analyses indicating that exotic species have impaired the beneficial uses of certain California waters. A report submitted to the State Water Resources Control Board.

${ }^{17}$ Bax, N., A. Williamson, M. Aguero, E. Gonzalez, and W. Geeves. 2003. Marine invasive alien species: a threat to global biodiversity. Marine Policy 27(4):

313-323.

${ }^{18}$ Protect Your Waters: Harmful Aquatic Hitchhikers: Mollusks: New Zealand Mudsnail. http:/www.protectyourwaters.net/hitchhikers/mollus ks_new_zealand_mudsnail.php Accessed February 3, 2006.

${ }^{19}$ United States Geological Society. Aquatic

Resource Studies-Gainesville. New Zealand Mudsnail (Potamopyrgus antipodarum). http://cars.er.usgs.gov/Nonindigenous_Species/New_ Zealand_Mudsnail/new_zealand_mudsnail.html Accessed February 3, 2006.
${ }^{20}$ Veldhuizen, T. and K. Hieb. "What difference can one crab make? The ongoing tale of the Chinese Mitten crab and the San Francisco Estuary.” Outdoor California. May-June 1998.

${ }^{21}$ Veldhuizen, T. and K. Hieb. "What difference can one crab make? The ongoing tale of the Chinese Mitten crab and the San Francisco Estuary." Outdoor California. May-June 1998.

${ }^{22}$ Rudnick, D., T. Veldhuizen, R. Tullis, C. Culver, K. Hieb, and B. Tsukimura. 2005. A life history model for the San Francisco Estuary population of the Chinese mitten crab, Eriocheir sinensis (Decapoda: Grapsoidea). Biological Invasions 7:333350.

${ }^{23}$ San Francisco Estuary Project. 2000. State of the Estuary: Restoration Primer: San Francisco Bay Sacramento-San Joaquin River Delta Estuary. http://sfep.abag.ca.gov/pdf/restoration_primer/Restor ation_Primer\%5Bp1-15\%5D.pdf Accessed February 22, 2007.

${ }^{24}$ Veldhuizen, T. and K. Hieb. "What difference can one crab make? The ongoing tale of the Chinese Mitten crab and the San Francisco Estuary.” Outdoor California. May-June 1998.

${ }^{25}$ Veldhuizen, T. and K. Hieb. "What difference can one crab make? The ongoing tale of the Chinese Mitten crab and the San Francisco Estuary." Outdoor California. May-June 1998.

${ }^{26}$ Veldhuizen, T. and K. Hieb. 1998. What difference can one crab species make? The ongoing tale of the Chinese Mitten crab and the San Francisco Estuary. Outdoor California (May-June): 19-21.

${ }^{27}$ Siegfried, S. 1999. Notes on the invasion of the Chinese mitten crab (Eriocheir sinensis) and their entrainment at the Tracy Fish Collection Facility. Interagency Ecological Project Newsletter 12(2):2425.

${ }^{28}$ Veldhuizen, T. and S. Stanish. 1999. Overview of the life history, distribution, abundance, and impacts on the Chinese mitten crab, Eriocheir sinensis. California Department of Water Resources, Sacramento, California.

${ }^{29}$ Rudnick, D.A. and V.H. Resh. 2002. A survey to examine the effects of the Chinese mitten crab on commercial fisheries in northern California. Interagency Ecological Program Newsletter 15(1):19-21.

${ }^{30}$ California Department of Fish and Game. 2003. California Aquatic Invasive Species Management Plan. Draft.

${ }^{31}$ Veldhuizen, T. and K. Hieb. 1998. What Difference Can One Crab Species Make? The Ongoing Tale of the Chinese Mitten Crab and the San Francisco Estuary. Outdoor California. Pg.19-21. 
${ }^{32}$ Cohen, A. and P. Moyle. 2004. Summary of data and analyses indicating that exotic species have impaired the beneficial uses of certain California waters. A report submitted to the State Water Resources Control Board.

${ }^{33}$ PCAO (Pima County Administrator's Office). UNDATED. Sonoran Desert Conservation Plan Fact Sheets - Exotic species: northern crayfish. Pima County, Arizona. http://www.co.pima.az.us/cmo/sdcp/sdcp2/fsheets/ex/ cray.html Accessed July 13, 2003.

${ }^{34}$ NAS (Nonindigenous Aquatic Species). UNDATED. Orconectes virilis. United States Geological Survey. http://nas.er.usgs.gov/crustaceans/maps/or_virilis.gif Accessed July 23, 2003.

${ }^{35}$ Fullerton, A. 2002.Orconectes virilis. North Carolina Wildlife Resources Commission. http://www.ncwildlife.org/pg07_WildlifeSpeciesCon/ nccrayfishes/o_virilis/o_virilis.html Accessed July 21, 2003.

${ }^{36}$ Global Invasive Species Database. Orconectes virilis. Compiled by National Biological Information Infrastructure and Invasive Species Specialist Group. http://www.issg.org/database/species/ecology.asp?si= 218\&fr=1\&sts Accessed November 3, 2005.

${ }^{37}$ Bioinvaders of the Sonoran Desert. Arizona Sonora Desert Museum.

http://www.sonoran.org/programs/pdfs/Bioinvaders\% 20print\%20FINAL\%201.pdf Accessed November 3, 2005.

${ }^{38}$ Pavlineris. G. Everything About Fish. http://www.gpavlineris.com/id19.htm Accessed November 3, 2005.

${ }^{39}$ Global Invasive Species Database. Pacifastacus leniusculus. Compiled by National Biological Information Infrastructure and Invasive Species Specialist Group.

http://issg.appfa.auckland.ac.nz/database/species/ecol ogy.asp?si $=725 \& \mathrm{fr}=1 \&$ sts=sss Accessed November 3, 2005.

${ }^{40}$ Guan, R-Z. \& Wiles, P. R. 1997. Ecological impact of introduced crayfish on benthic fishes in a British lowland river. Conservation Biology 11(3): 641-647.

${ }^{41}$ Nystrom, P. 1999. Ecological impact of introduced and native crayfish on freshwater communities: European perspectives. In Gherardi, F. and Holdich, D.M. (eds.) Crustacean Issues 11: Crayfish in Europe as Alien Species (How to make the best of a bad situation?) A.A. Balkema, Rotterdam, Netherlands: 63-85.

${ }^{42}$ Bondar, C.A., K. Bottriell, K. Zeron, and J.S. Richardson 2005. Does trophic position of the omnivorous signal crayfish (Pacifastacus leniusculus) in a stream food web vary with life history stage or density? Can. J. Fish. Aquat. Sci. 62: 2632-2639.

${ }^{43}$ California Department of Fish and Game: Habitat Conservation Planning Branch. 2006.

http://www.dfg.ca.gov/hcpb/cgi-

bin/read_one.asp?specy=invertebrates\&idNum $=2$

Accessed : January 25, 2006.

Miller, M. 2004. Shasta crayfish (Pacifastacus fortis).

http://www.sonoma.edu/users/s/stokes/Shasta\%20cra yfish\%20revised.pdf Accessed January 25, 2006.

${ }^{44}$ Hiruta S. 1996. The presence of signal crayfish in Hokkaida, Japan. Crayfish NEWS 19 (1):12.

${ }^{45}$ Kawai, T. \& Hiruta, M. 1999. Distribution of crayfish (Pacifastacus leniusculus and Cambaroides japonicus) in Lake Shikaribetsu and Shihoro, Hokkaido, Japan. Crayfish NEWS 21 (3):11.

${ }^{46}$ Holdich, D.M. 1999. The negative effects of established crayfish populations. In Gherardi, F. and Holdich, D.M. (eds.) Crustacean Issues 11: Crayfish in Europe as Alien Species (How to make the best of a bad situation?) A.A. Balkema, Rotterdam, Netherlands: 31-48.

${ }^{47}$ Hiley, P. D. 2003. The slow quiet invasion of signal crayfish (Pacifastacus leniusculus) in England - prospects for the white-clawed crayfish (Austropotamobius pallipes), in Holdich D. M. \& Sibley, P. J. (Eds), Management \& Conservation of Crayfish. Proceedings of a conference held in Nottingham on 7th November, 2002. Environment Agency, Bristol: 127-138.

${ }^{48}$ Raaymakers, S. 2002. The Ballast Water Problem: Global Ecological, Economic, and Human Health Impacts. Paper Presented at the RECSO/IMO Joint Seminar on Tanker Ballast Water Management \& Technologies Dubai, UAE 16-18 Dec 2002.

${ }^{49}$ Raaymakers, S. 2002. The Ballast Water Problem: Global Ecological, Economic, and Human Health Impacts. Paper Presented at the RECSO/IMO Joint Seminar on Tanker Ballast Water Management \& Technologies Dubai, UAE 16-18 Dec 2002.

${ }^{50}$ Wittenberg, Rüdiger and Matthew J.W. Cock. (eds.) 2001. Invasive Alien Species: A Toolkit of Best Prevention and Management Practices. CAB International, Wallingford, Oxon, UK, xvii-228. http://www.cabibioscience.ch/wwwgisp/100Toolkitfin.pdf Accessed January 23, 2006.

${ }^{51}$ Global Invasive Species Database: Caulerpa taxifolia. 2005.

http://www.issg.org/database/species/ecology.asp?si= 115\&fr=1\&sts= Accessed January 23, 2006.

${ }^{52}$ United Nations Environment Programme. 2004. Caulerpa taxifolia: A growing menace for the temperate marine environment. 
http://www.grid.unep.ch/product/publication/downlo ad/ew_caulerpa.pdf Accessed January 23, 2006.

${ }^{53}$ Aguilar-Rosas, Luis E. and Raul. 2002. Baja California Still Free of the Invasive Marine Alga. Bight Bulletin (4):6.

${ }^{54}$ Aguilar-Rosas, Luis E. and Raul. 2002. Baja California Still Free of the Invasive Marine Alga. Bight Bulletin, (4): 8.

${ }_{55}$ National Management Plan for the Genus Caulerpa. 2005. Submitted to the Aquatic Nuisance Species Task Force, Prepared by the Caulerpa Working Group.

http://www.anstaskforce.gov/control.php Accessed: November 2005.

${ }^{56}$ Sala, Enric. 2001. Invading Seaweed Threatens California. Bight Bulletin (1):4.

${ }^{57}$ Murcott, T. 2000. "Killer Seaweed Hits California.” British Broadcast Corporation on the Web. http://news.bbc.co.uk/1/hi/sci/tech/823501.stm Accessed August 252005.

${ }^{58}$ Randall, John M. 2004. "Re: Docket No 04-037-1, request for comments on two petitions to regulate the genus Caulerpa and the entire species, Caulerpa taxifolia,"

https://web01.aphis.usda.gov/regpublic.nsf/2e3b06d7 0097f14c85256f410043a574/8aafcf2d8d3720258725 6f77006ee07e?OpenDocument Accessed July 2005.

${ }^{59}$ Cohen, A.N. 2004. Invasions in the sea. National Park Service: Park Science 22(2).

${ }^{60}$ Brochure. "Destructive Seaweed Threatens California Caulerpa taxifolia.” National Marine Fisheries Service, California Dept. of Fish and Game, SD Regional Water Quality Control Board.

${ }^{61}$ Aguilar-Rosas, Luis E. and Raul. 2002. Baja California Still Free of the Invasive Marine Alga. Bight Bulletin (4):8.

${ }^{62}$ Cohen, A.N. 2004. Invasions in the sea. National Park Service: Park Science 22(2).

${ }^{63}$ Wittenberg, Rüdiger and Matthew J.W. Cock. (eds.) 2001. Invasive Alien Species: A Toolkit of Best Prevention and Management Practices. CAB International, Wallingford, Oxon, UK, xvii-228.

${ }^{64}$ Raaymakers, S. 2002. The Ballast Water Problem: Global Ecological, Economic, and Human Health Impacts. Paper Presented at the RECSO/IMO Joint Seminar on Tanker Ballast Water Management \& Technologies Dubai, UAE 16-18 Dec 2002.

${ }^{65}$ O'Hara, P. 1993. Overview of the marine biotoxin crisis in 1993. Pages 3-6 in: Marine Toxins and New Zealand Shellfish, J.A. Jasperse (ed.), Royal Society of New Zealand, Misc. Ser. 24.

${ }^{66}$ Cohen, A. and J. Carlton. 1995. Nonindigenous Aquatic Species in a United States Estuary: A Case Study of the Biological Invasions of the San Francisco Bay and Delta. A Report for the United
States Fish and Wildlife Service, Washington D.C. and the National Sea Grant College Program Connecticut Sea Grant.

${ }^{67}$ Cohen, A. N., J. T. Carlton. 1995. Nonindigenous Aquatic Species in a United States Estuary: A Case Study of the Biological Invasions of the San Francisco Bay and Delta. United States Fish and Wildlife Service, Washington D.C. and The National Sea Grant College Program, Connecticut Sea Grant.

${ }^{68}$ United States Army Corps of Engineers. Engineer Research and Development Center. Environmental Laboratory, "Eichhornia crassipes (Mart.) Solms (Waterhyacinth) - Aquatic Plant Information System.” http://el.erdc.usace.army.mil/aqua/apis/plants/html/ei chhorn.html Accessed September 8, 2005.

${ }^{69}$ Cohen, A. and P. Moyle. 2004. Summary of data and analyses indicating that exotic species have impaired the beneficial uses of certain California waters. A report submitted to the State Water Resources Control Board.

${ }^{70}$ Cohen, A. and P. Moyle. 2004. Summary of data and analyses indicating that exotic species have impaired the beneficial uses of certain California waters. A report submitted to the State Water Resources Control Board. 


\section{Risk-Management Strategies for Aquatic Invasive Species}

This section will discuss risk-management techniques and strategies for preventing and controlling aquatic invasive species (AIS) with special emphasis on hull-borne species.

Management strategies may employ various techniques, often in combination, to control risks posed by AIS, such as prevention, eradication, containment, control, mitigation, quarantine, technology, and education. Techniques are selected according to whether the species has become established and other considerations.

The United States is employing the " $100^{\text {th }}$ Meridian Strategy" to prevent the spread of zebra mussels. The Aquatic Invasive Species - Hazard Analysis Critical Control Points (AIS-HACCP) strategy identifies situations in which particular control techniques are likely to be most effective, for example to control AIS on hulls of boats traveling in California and Baja California.

Because Australia has implemented invasive species policies and regulations, which are ahead of those of most other nations, we have provided many examples of their efforts.

Some of the examples discussed in Sections $\mathrm{V}$, VI and VII will be examined in the context of strategies for invasive species control. Section IX discusses the interplay of antifouling laws with water quality and invasive species policies, and includes information on nontoxic and other alternative antifouling strategies that may help to resolve conflicts in water quality and invasive species policies with respect to boat bottom coatings. Section XII considers riskmanagement strategies for boats traveling in California and Baja California.

\section{Prevention}

Most scientists would agree that the easiest way to combat bioinvasions is through prevention or interception. Financial burdens imposed by even a single invasive species, such as the loss of an entire fishery on the United States' Atlantic Coast or the exorbitant costs associated with zebra mussels in the Great Lakes, far outweigh expenses necessary to prevent the establishment of invasive species. ${ }^{1}$ The United States' legal regime to prevent the hull transport of AIS is discussed further in Section XI.

New Zealand and Australia have implemented preventive measures to discourage AIS introductions. Prior to arrival, every craft is required to give 48 hours notice to the New Zealand Customs Service and Ministry of Agriculture and Forestry Quarantine of the expected port of entry and time of arrival. ${ }^{2}$ Although they do not require hull inspections, Biosecurity New Zealand recommends collecting and disposing of plant and animal life away from the coastal marine area, or having vessels cleaned in a facility where waste material, which could contain marine pests, is collected and disposed in the same manner. ${ }^{3}$

The Australian Quarantine and Inspection Service (AQIS) requires pre-arrival notification from all vessels entering Australia from overseas. Vessels must enter Australia at one of 65 proclaimed ports, unless special permission is obtained. Unreported/unsanctioned entries are treated severely. ${ }^{4}$ All international vessels greater than 25 meters in length are required to submit a Quarantine Pre-Arrival Report 12 to 48 hours prior to arrival. Information in the report is used by AQIS to assess human, plant and animal health risks (including 
ballast water). AQIS inspects all vessels upon arrival. ${ }^{5}$

This may be an inexpensive, comprehensive method for assessing the risk that a vessel may be carrying an invasive species. The port or marina authority could determine from the questionnaire whether a hull inspection would be needed. Such a procedure could significantly reduce AIS introductions, while controlling costs and minimizing inconvenience to vessel owners.

AQIS implemented voluntary guidelines in October 2005 for internationally plying vessels under 25 meters in length The requirements ask vessel owners to ensure their boats are free of potentially invasive species before leaving their last port for Australia:

"Keep all ancillary gear and internal seawater systems clean of marine pests and growth; and clean your vessel's hull within one month before arrival; or apply antifouling paint within one year before arrival; or book your vessel in to be slipped and cleaned within one week of arrival.”

They ask boat owners to pay special attention to the high risk areas: "hull, keel and rudder; propellers and shafts; anchor wells (including anchor chain and rope); water intakes and outlets; tenders and outboard motors; and sea strainers and internal water systems.”

Under Australia's (currently voluntary) biofouling guidelines internationally plying vessels less than 25 meters in length are inspected upon arrival in port to assess the presence of biofouling on hulls, ancillary gear (anchors, cables, etc) and internal water systems. The purpose of the voluntary phase is to educate small craft operators about biofouling concerns and gather information about biofouling occurrences and maintenance practices. During the voluntary phase, AQIS will recommend (or order in extreme cases) that vessels with fouled hulls be removed from the water. Hulls can then be cleaned or left on a hardstand until all biofouling has died (two weeks is recommended). Alternatively, vessels will be able to leave the Australian territorial sea $(12 \mathrm{~nm})^{6}$ if they do not wish to comply. ${ }^{7}$ After a review of the voluntary phase, these requirements will likely become mandatory July $1,2007 .{ }^{8}$

Other treatments for hulls suspected of carrying invasive species may include biocide application, water immersion, heat and cold treatment, pressure or irradiation. ${ }^{9}$ The Manitoba Water Stewardship has suggested that cleaning hulls with hot water $\left(80^{\circ} \mathrm{C}\right)$ and soap can destroy zebra mussel colonies. Leaving a boat out of the water in the sun for three to five days can exterminate many hull fouling organisms. ${ }^{10}$ Freshwater treatment can eliminate marine fouling on ships. Ultraviolet radiation is also effective. $^{11}$

When the non-indigenous species has already been introduced, eradication, containment, control, mitigation and quarantine can be employed. ${ }^{12}{ }^{13}$ Education is necessary to obtain the public cooperation that is vital to success in prevention and other techniques.

\section{Eradication}

Eradication is the complete removal of AIS from the recipient region. Eradication of AIS in marine waters has only been documented for a few rare cases. "Handpicking, biopesticides, sterile male release, and habitat management" are examples of eradication techniques. ${ }^{14}$ The Green Crab 
Control Committee has stated that eradication works best when small numbers of an invasive species have become established and there is a very slim possibility of spreading. ${ }^{15}$

The invasive black-striped mussel (Mytilopsis sallei), discussed in Section VI of this report, was the first marine pest recorded in Australian tropical waters. Riskassessment and analysis were performed to determine whether it was economically and environmentally worthwhile to eradicate the black-striped mussel. This included determining vectors that may have brought them to Australia and classifying different regions of the affected marina as "confirmed high risk areas," "high risk areas," "medium risk areas," and "low-risk areas." From March $27^{\text {th }}$, 1999, when the mussel was first discovered, until May $8^{\text {th }}$, when a 21 day "all clear" phase was implemented, Commonwealth Scientific and Industrial Research Organization (CSIRO) Centre for Research Into Marine Pests, divers, scientists, and government officials worked diligently together to eradicate the mussels from Australian waters. ${ }^{16} 17$

After the vessels and areas were prioritized, 28 divers were selected to patrol the areas of Darwin Harbour, Gove Harbour, and Cullen Bay Marina to determine where the mussels had invaded. Treatments were evaluated to determine which would be the most appropriate, chlorine and copper sulphate were selected, the harbor's locks were closed and the chemicals were applied. This was one of the few successful eradications of an aquatic invasive species; twelve months after treatment, the area was examined and no black-striped mussels were found. ${ }^{18}$ Vessels that had left the site before the eradication were tracked and treated. ${ }^{19} 20$
In Central California, the South African sabellid tubeworm (Terebrasabella heterouncinata) infested abalone farms and was found in the intertidal zone of at least one cove. This invasive, shell parasite can deform and stop the growth of all West Coast abalone species, as well as other marine snails. Its effects on native snail populations could alter seaweed communities, affecting habitat and food resources for many other species. ${ }^{21}$

Approximately 1.6 million snails were removed from the affected cove, reducing the host population to a level that was too low to sustain the parasite. ${ }^{22}$

The eradication of the invasive seaweed Caulerpa taxifolia in two Southern California lagoons has been successful to date. ${ }^{23}$ The Southern California Caulerpa Action Team was assembled to plan and implement the eradication effort. The team represented stakeholders, such as the local power plant, recreational users, aquaculture businesses, scientists, government and environmental organizations ${ }^{24}$

US\$1.1 million was spent in the first year at Agua Hedionda Lagoon on a laborintensive, eradication strategy. Survey teams located C. taxifolia infestations, which were treated by either pumping liquid chlorine under tarps or by placing solid chlorine pucks among them and then covering them with PVC tarps. ${ }^{25}$

Funds spent in subsequent years primarily supported surveillance. ${ }^{26}$ Educational brochures were developed to educate aquarium shops, hobbyists and others who might encounter Caulerpa. ${ }^{27}$ Overall, more than US\$4.5 million in federal, state, and private funds has been spent to eradicate Caulerpa taxifolia at Huntington Harbor and Agua Hedionda Lagoon. ${ }^{28} 29$ 


\section{Containment}

Containing invasive species involves confining them within a defined area and stabilizing their populations. ${ }^{30}$ With regard to hull-borne species, circumstances should be determined in which fouling growth removed from hulls should be contained. If potential invaders are released into the water, they may reattach to boat bottoms or become established in the environment. The zebra mussel (Dresseina polymorpha) probably became widespread in Ireland in this manner. ${ }^{31}$

In Australian ports, in-water hull cleaning is prohibited for vessels arriving from international waters because it could release invasive species into the local environment. Boats that travel locally are not subject to this restriction; careening posts in many locations around the nation are available for their use. The AQIS is concerned about fouling organisms removed from boats' hulls being released to the sea. Tony Snell of AQIS is not aware of any special charges for dumping fouling growth into landfills. In most boatwashing facilities solid material filtered from the wash water is collected in traps. When the traps are emptied, the solids are sent to landfill dumps along with general waste. ${ }^{32}$

In the state of Victoria, Australia, a coordinated strategy was prepared to minimize invasive introductions by hull cleaning. The underwater sections of vessels greater than 200 tons must not be cleaned in Victoria marine waters except in accordance with a specific code of practice. Waste cleaned from vessels less than 200 tons must be disposed in an approved landfill. ${ }^{33}$

According to Dr. Oliver Floerl, in New Zealand most hull cleaning facilities are not allowed to discharge solid fouling waste back into the sea, primarily because sediments would be polluted by chemicals in flakes of antifouling paint. All facilities must prove that they can retain solid materials in order to get their resource consent and permit to operate the cleaning facility. Throughout most of the country, inwater hull cleaning is not strictly forbidden, but the government is trying to establish regulations. Floerl believes that regulations should prevent all biological material from being discharged into the water, rather than allowing a certain amount. Species introductions are stochastic events and can occur if a handful of organisms are released. ${ }^{34}$

Floerl has found that $80 \%$ of New Zealand boats do not travel much or only short distances; $10 \%$ are used for wider-reaching domestic trips and another $10 \%$ are used for international travel. ${ }^{35}$ Hence, caution should be taken before applying blanket regulations, which may unfairly target boats that do not pose a risk.

San Diego, California hull cleaners recommend avoiding cleaning the hulls of vessels arriving from long-distance voyages inside harbors. ${ }^{36}{ }^{37}$ One company would welcome the opportunity to offer hull cleaning service to long-distance boaters in deeper waters outside the harbors.

In San Diego, if fouling growth were disposed in a landfill it would cost: \$35/ton for loads less than 2 tons and $\$ 43 /$ ton for loads more than 2 tons. Landfills do not generally accept loads with more than $50 \%$ moisture. ${ }^{38}$ According to Lisa Wood of the City of San Diego Environmental Services Department, the Miramar landfill would likely take fouling growth collected by hull cleaners, provided it contained nothing more than a low concentration of copper. ${ }^{39}$ Kirk Galarno of the same department said that, if 
the fouling growth were to be tested for metals as part of the waste determination requirement for the landfill, the full scan to determine metal content would cost between US\$200 and US\$250. ${ }^{40}$

\section{Control}

In controlling an invasive species, efforts are aimed at keeping the population low enough that it can be expected to have minimal economic or environmental effects. Controlling the population of the invasive species may enable native species to regain the upper hand, and perhaps drive out the alien species, returning the ecosystem to its former state. Methods used to control populations of invasive species include mechanical, chemical, and biological controls as well as habitat management. ${ }^{41}$

Introductions of AIS may be prevented by focusing on the control of fouling growth on vessels traveling internationally and other long distances. Control measures that might be considered include:

1. hauling the vessels and collecting and disposing the growth (as they are considering, during the voluntary phase, in Australia);

2. allowing fouled vessels to sit out of water for two weeks until the fouling growth is dead (as they are considering, during the voluntary phase, in Australia); and/or

3. cleaning hulls outside harbors in deeper water, where fouling growth would not be able to reattach as easily to other boats or structures and would be less likely to survive (recommended by San Diego hull cleaners).

In Germany, extensive efforts were undertaken by the government in the 1920s and 1930s to control mitten crab populations. Dams or deep trenches were dug alongside levees, and traps were placed on the upstream side to capture migrating crabs. At one site, over 113,000 crabs were trapped in a single day. ${ }^{42}$

Biological control has been investigated with the introduction of a European rhizocephalan barnacle, Sacculina carcini. ${ }^{43}$ This barnacle is a parasitic castrator that can theoretically control host populations. ${ }^{44}$ In Europe, it has substantially reduced green crab densities in some locations. ${ }^{45}$ The susceptibility of crabs native to the U.S. Pacific Coast to infection by $S$. carcini is being investigated in the laboratory. If it proves to be safe for native crabs, improved technology would be required to grow enough parasitic barnacles to infect large numbers of green crabs. Implementation of the biological control might include a program of trapping and infecting crabs that would also serve as a means to monitor the success of the control effort. ${ }^{46}$ When evaluating costs and benefits of such a control program, the value of affected fisheries must be taken into account as well as the value of the ecosystem in which native organisms thrive.

Although control does not eliminate entire communities of non-indigenous species, it may be a more economically feasible alternative to eradication. The Green Crab Control Committee has stated that control and containment are most appropriate when the species has settled into the new region and has begun to increase its range. ${ }^{47}$

\section{Mitigation}

Mitigation is an attempt to alleviate negative impacts of invasive species upon the new environment. ${ }^{48}$ In this strategic option, actions are not taken against the exotic species. Instead, native species that have 
been affected by the introduction of invasive species are targeted or the environment in which they live is controlled.

If eradication, containment, and control are not options or have failed in managing an invasive non-indigenous species, the last resort is to "live with" this species in the best possible way and to mitigate impacts on biodiversity and endangered species.

Mitigation is most commonly used in the conservation of endangered species and can be approached at various levels. At its simplest and perhaps more extreme form it could mean the translocation of a viable population of the endangered species to an ecosystem where the invasive species of concern does not occur or, in the case of a rehabilitated system, no longer occurs. It should be noted that mitigation can be labor intensive and costly and is often seen as an intermediate measure to be taken in tandem with eradication, containment or control. Immediate mitigation efforts may be employed to rescue a critically endangered native species from extinction. ${ }^{49}$

According to the Convention on Biological Diversity, mitigation measures should take place in the earliest possible stage of invasion. Hence, early detection of an alien species that is potentially or known to be invasive is important. Detection should be followed rapidly by actions to mitigate effects on native species and to prevent the potential invader from becoming established. $^{50}$

Mitigation was successful in protecting the endangered Black Parrot in Seychelles, but successful examples in the ocean are rare. ${ }^{51}$ The Green Crab Control Committee has asserted that, if the population of invasive species has completely colonized and a management technique is not yet implemented, mitigation may be viable. ${ }^{52}$

\section{Quarantine}

As discussed above, the Northern Territory Government of Australia eradicated the black-striped mussel from marinas in Darwin. Quarantine was a part of the strategic approach. The affected marinas were quarantined, and chemicals were added to kill the mussels. Boats and ships quarantined at the harbors and marinas were removed from the water and thoroughly cleaned. Policies to prevent future invasions allow arriving vessels to be quarantined if they are suspected of carrying invasive species.

California attempts to exclude infested boats at California border crossings. The California Department of Food and Agriculture inspects boats that are brought in by commercial haulers, and if zebra mussels are detected, the boats are placed into quarantine until cleaned, inspected and released by the Department of Fish and Game. $^{53}$

\section{Education and Outreach}

Public education is an important invasive species management tool. Section XII and Appendix F present extensive research, education and outreach recommendations from stakeholders at the May 11, 2005 Workshop, "Managing Hull Transport of Aquatic Invasive Species," and from the authors' analyses and conclusions. Following are several examples of education and outreach programs that are underway.

Throughout the black-striped mussel eradication at Darwin, Australia, marina owners, other stakeholders, and government officials were kept well informed. A 
nationwide committee oversaw protocols and legislation relevant to eradicating the mussel. A monitoring system was established and a public awareness program was implemented. $^{5455}$

A mail survey conducted in Minnesota, Ohio, Vermont, Kansas, and California found that as more funds were used to inform the public of the dangers of AIS, the more likely it was that boat owners would take action to prevent them from spreading. When boaters were told about the effects of specific invaders, they were more likely to personalize the problem, stating that they would rather keep the species "out of my lake," and that "it is my personal responsibility."56

The Sea Grant Non-indigenous Species Site (SGNIS) is a national information center that contains a comprehensive collection of research publications and education materials produced by Sea Grant programs and other research institutions across the country on zebra mussels and other aquatic nuisance species. ${ }^{57}$

The Aquatic Nuisance Species (ANS) Task Force is an intergovernmental organization dedicated to preventing and controlling aquatic nuisance species, and implementing the Non-indigenous Aquatic Nuisance Prevention and Control Act (NANPCA) of 1990. The various NANPCA mandates were expanded later with the passage of the National Invasive Species Act in 1996. The Task Force consists of 10 Federal agency representatives and 12 ex officio members. It is co-chaired by the U.S. Fish and Wildlife Service and National Oceanic and Atmospheric Administration. The Task force coordinates governmental efforts dealing with ANS in the U.S. with those of the private sector and other North American interests via regional panels and issue- specific committees and work groups. Task Force members, ex officio members, Regional Panels, States, and other entities such as Sea Grant have conducted workshops, created traveling information displays, exhibits, pamphlets, information sheets, wallet identification cards, videos, websites and innumerable other public education venues for distribution across the country. ${ }^{58}$

The Stop Aquatic Hitchhikers and Habitattitude $^{\mathrm{TM}}$ websites are part of the ANS Task Force public awareness campaign. The U.S. Fish and Wildlife Service serves as the lead federal agency for Habitattitude ${ }^{\mathrm{TM}}$.

Both the U.S. Fish and Wildlife Service and U.S. Coast Guard sponsor the Stop Aquatic Hitchhikers website.

\section{$100^{\text {th }}$ Meridian Initiative}

The $100^{\text {th }}$ Meridian Initiative is a containment strategy in which federal, state, provincial and local agencies are cooperating. It is a seven-step program designed to prevent zebra mussels from spreading no further west than the $100^{\text {th }}$ longitudinal meridian that runs through Manitoba, the Dakotas, Nebraska, Kansas, Oklahoma and Texas. The steps are:

1. Inform and educate the public about zebra mussels, including how they are transported and their impacts.

2. Conduct voluntary examination of vessels and related equipment as well as questionnaires designed to determine whether the boat is at risk of infestation.

3. Include boats used for commercial purposes, such as fishing boats.

4. Monitor the water so that action can be taken as soon as zebra mussels are detected.

5. If zebra mussels are detected, act immediately to eradicate or control them. 
6. Determine other vectors or pathways that may contribute to zebra mussel infiltration and assess the likelihood that these pathways can introduce them.

7. Maintain the efficacy of the $100^{\text {th }}$ Meridian Initiative. ${ }^{59}$

\section{AIS-HACCP Strategy}

An Aquatic Invasive Species - Hazard Analysis and Critical Control Points (AISHACCP) strategy seeks to control the spread of AIS, while maintaining viable marine resource uses, such as fisheries, aquaculture, boating and shipping. It focuses on places and activities that are most likely to spread invasive species and views prevention as a process with seven steps:

1. Analyze steps in the process where significant hazards occur and describe preventive measures.

2. Identify the critical control points (CCPs) in the process.

3. Establish controls for each CCP.

4. Establish CCP monitoring and use the results to adjust the process.

5. Establish actions to correct problems when monitoring indicates a critical limit has been exceeded.

6. Establish procedures to verify that the HACCP system is working correctly.

7. Establish effective record-keeping to document the HACCP system. ${ }^{60}$

An AIS-HACCP approach may be suitable for developing feasible and effective measures to control hull-borne invasive species on boats traveling along the California coast and between California and other areas. Such an approach is discussed in Section XII of this report.

\section{Global Strategy}

At the Commonwealth Agricultural Bureau International Workshop on Alien Invasive
Species in Chennai, India the following recommendations were proposed to manage AIS:

1. Create public awareness of the threats of AIS to enhance the success of efforts to manage them and to prevent further introductions.

2. Conduct research to fill the gaps of knowledge of the AIS problem.

Research is required to measure the social, economic, and ecological impacts of AIS.

3. Raise awareness at the local level to empower communities in detection, monitoring and management of AIS affecting local resources.

4. At the state level, build institutional capacity for research into invasions and their prevention and develop appropriate legislation.

5. At the national level, coordinate in a holistic manner by developing an interorganizational program including research and education.

6. At the regional level, strengthen cooperation on shared AIS problems and develop complementary legislation.

7. At the global level, share experiences in AIS management and development of effective legislation. ${ }^{61}$

Clearly, a regional approach will be needed to control invasive species introductions from hulls of pleasure craft and commercial fishing boats traveling along the Pacific coast of North America. A global perspective in which experiences and technologies are shared would be helpful in designing programs to control longerdistance, hull-borne transportation of invasive species by such small craft. Experiences of invasive species managers in Hawaii, Australia and New Zealand may provide useful insights for designing state, national and regional programs for the North American Pacific Coast. 


\section{References}

${ }^{1}$ Wittenberg, Rüdiger and Matthew J.W. Cock. (eds.) 2001. Invasive Alien Species: A Toolkit of Best Prevention and Management Practices. CAB International, Wallingford, Oxon, UK, xvii-228. ${ }^{2}$ New Zealand Ministry of Agriculture and Forestry. 2005. http://www.maf.govt.nz/quarantine/shipsyachts/index.htm\#yachts Accessed November 8, 2005.

${ }^{3}$ Biosecurity New Zealand. 2005. Is your boat spreading marine pests? http://www.maf.govt.nz/quarantine/shipsyachts/yacht-fact-sheet-2005version-with-yacht-1.pdf Accessed November 8, 2005.

4 Australian Quarantine and Inspection Service. 2005. First port of entry into Australia. http://www.affa.gov.au/corporate_docs/publications/ html/quarantine/factsheets/first_port_of_entry.pdf Accessed November 8, 2005.

${ }^{5}$ Australian Quarantine and Inspection Service. 2004. Quarantine Pre-Arrival Report for Vessels.

Quarantine Act 1908 Section 27A.

http://www.daff.gov.au/corporate_docs/publications/ html/quarantine/quarantine/qpar_1_march_2004.pdf Accessed November 8, 2005.

${ }^{6}$ Snell, T. 2005. Australian Quarantine and Inspection Services (AQIS), National Ballast Water Adviser, personal communication, September 27, 2005.

${ }^{7}$ Australian Quarantine and Inspection Service. 2005. New Biofouling Protocols.

http://www.daff.gov.au/content/output.cfm?ObjectID =7FBA840F-4324-49E3-B22BCB2C4A3B28E8

Accessed November 8, 2005.

${ }^{8}$ Snell, T. 2006. Australian Quarantine and Inspection Services (AQIS), National Ballast Water Adviser, personal communication, December 20, 2006.

${ }^{9}$ Wittenberg, Rüdiger and Matthew J.W. Cock. (eds.) 2001. Invasive Alien Species: A Toolkit of Best Prevention and Management Practices. CAB International, Wallingford, Oxon, UK, xvii-228. ${ }^{10}$ Manitoba Water Stewardship. Fish and Habitat: Aquatic Invasive Species.

http://www.gov.mb.ca/waterstewardship/ais/

Accessed July 12, 2005.

${ }^{11}$ Wittenberg, Rüdiger and Matthew J.W. Cock. (eds.) 2001. Invasive Alien Species: A Toolkit of Best Prevention and Management Practices. CAB International, Wallingford, Oxon, UK, xvii-228.

${ }^{12}$ Wittenberg, Rüdiger and Matthew J.W. Cock. (eds.) 2001. Invasive Alien Species: A Toolkit of
Best Prevention and Management Practices. CAB International, Wallingford, Oxon, UK, xvii-228. ${ }^{13}$ Elton, Charles S. 1958. The Ecology of Invasions by Animals and Plants. University of Chicago Press, Chicago, Illinois.

${ }^{14}$ Wittenberg, Rüdiger and Matthew J.W. Cock. (eds.) 2001. Invasive Alien Species: A Toolkit of Best Prevention and Management Practices. CAB International, Wallingford, Oxon, UK, xvii-228.

${ }^{15}$ Grosholz, Edwin and Gregory Ruiz (eds). 2002. Management Plan for the European Green Crab. Submitted to the Aquatic Nuisance Species Task Force.

${ }^{16}$ Bax, N. K. Hayes, A. Marshall, D. Parry, and R. Thresher. 2004. Man-made marinas as sheltered island for alien marine organisms: Establishment and eradication of an alien invasive marine species. Paper from Turning the Tide: The Eradication of Invasive Species, Proceedings of the International Conference on Eradication of Island Invasives. ${ }^{17}$ CSIRO Centre for Research on Introduced Marine Pests 2001. Marine Pest Information Sheet-Vessel and Gear Fouling. http://www.marine.csiro.au/crimp/Reports/Infosht3_ Fouling_A3S.pdf Accessed August 24, 2005.

${ }^{18}$ Bax, N. K. Hayes, A. Marshall, D. Parry, and R. Thresher. 2004. Man-made marinas as sheltered island for alien marine organisms: Establishment and eradication of an alien invasive marine species. Paper from Turning the Tide: The Eradication of Invasive Species, Proceedings of the International Conference on Eradication of Island Invasives.

${ }^{19}$ Ferguson, R. 2000. The effectiveness of Australia's response to the Black Striped Mussel incursions in Darwin, Australia. A Report of the Marine Pest Incursion Management Workshop August 27-28 1999. Research report produced by the Department of Environment and Heritage.

${ }^{20}$ Bax, N.J. 1999. Eradicating a dreissenid from Australia. Dreissena! 10(3):1-5.

${ }^{21}$ Cohen, A.N. 2004. Invasions in the sea. National Park Service: Park Science 22(2).

22 Culver, C.S. and A.M. Kuris. 2000. The apparent eradication of a locally established marine pest. Biological Invasions 2:245-253.

${ }^{23}$ Jirik, A. 2005. Aquatic Invasive Species in the Port of Los Angeles. Personal communication, August 11, 2005.

${ }^{24}$ Agua Hedionda Lagoon User Representatives, Southern California Caulerpa Action Team, City of Carlsbad Policy Department, Planning Department. 2002. Interim Management Plan to Facilitate the Agua Hedionda Lagoon Caulerpa Taxifolia Eradication Program. 
${ }^{25}$ Merkel, K., and R. Woodfield. 2003. Eradication and Surveillance of Caulerpa taxifolia within Agua Hedionda Lagoon, Carlsbad, California. Second Year Status Report, Fall 2001 through Summer 2002. Prepared for Steering Committee of the Southern California Caulerpa Action Team.

${ }^{26}$ Woodfield, R., and K. Merkel. 2005. Eradication and Surveillance of Caulerpa taxifolia within Agua Hedionda Lagoon, Carlsbad, California. Fourth Year Status Report Fall 2003 through Fall 2004. Prepared for Steering Committee of the Southern California Caulerpa Action Team.

${ }^{27}$ Merkel, K., and R. Woodfield. 2003. Eradication and Surveillance of Caulerpa taxifolia within Agua Hedionda Lagoon, Carlsbad, California. Second Year Status Report, Fall 2001 through Summer 2002. Prepared for Steering Committee of the Southern California Caulerpa Action Team.

${ }^{28}$ Southern California Caulerpa Action Team. Program Funding. http://www.sccat.net/funding.php Accessed August 29, 2005.

${ }^{29}$ Ellis, Susan. California Department of Fish and Game, Sacramento, CA. January 23, 2006.

${ }^{30}$ Wittenberg, Rüdiger and Matthew J.W. Cock. (eds.) 2001. Invasive Alien Species: A Toolkit of Best Prevention and Management Practices. CAB International, Wallingford, Oxon, UK, xvii-228. ${ }^{31}$ Michin, D. and S. Gollasch. 2003. Fouling and Ships' Hulls: How Changing Circumstances and Spawning Events May Result in the Spread of Exotic Species. Biofouling 19 (Supplement): 111-122.

${ }^{32}$ Snell, T. 2005. Australian Quarantine and Inspection Services (AQIS), National Ballast Water Adviser, personal communication, September 27, 2005.

${ }^{33}$ EPA Victoria. 1999. Protecting the Victorian Marine Environmental from marine pest: draft industrial waste management policy (ships' ballast water and hull cleaning) and draft policy impact statement. Environment Protection Authority, State Government of Victoria. Publication No. 676.

${ }^{34}$ Floerl, O. 2005. National Institute of Water and Atmospheric Research (NIWA), National Centre for Aquatic Biodiversity and Biosecurity, personal communication, September 27, 2005.

${ }^{35}$ Floerl, O. 2005. National Institute of Water and Atmospheric Research (NIWA), National Centre for Aquatic Biodiversity and Biosecurity, personal communication, September 27, 2005.

${ }^{36}$ Hoffman, M. 2005. California Marine Services, personal communication, September 29, 2005.

${ }^{37}$ Rashick, B. 2005. Alpha One Diving, personal communication, September 29, 2005.
${ }^{38}$ Ewert, B. 2005. Miramar, San Diego, California landfill biologist, personal communication, September 28, 2005.

${ }^{39}$ Wood, L. 2005. City of San Diego Environmental Services Department, personal communication September 28, 2005.

${ }^{40}$ Galarno, K. 2005. City of San Diego

Environmental Services Department, personal communication September 29, 2005.

${ }^{41}$ Wittenberg, Rüdiger and Matthew J.W. Cock. (eds.) 2001. Invasive Alien Species: A Toolkit of Best Prevention and Management Practices. CAB International, Wallingford, Oxon, UK, xvii-228. ${ }^{42}$ Veldhuizen, T. and K. Hieb. "What difference can one crab make? The ongoing tale of the Chinese Mitten crab and the San Francisco Estuary.” Outdoor California. May-June 1998.

${ }^{43}$ Lafferty, K.D. and A.M. Kuris. 1996. Biological control of marine pests. Ecology 77:1989-2000.

${ }^{44}$ Lafferty. K.D. 2002. Biological control of marine invasions. Biological Invasions in Aquatic Ecosystems: Impacts on Restoration and Potential for Control. Proceedings of a Workshop. April 25, 1998. Sacramento, California. Cohen, A.N. and S.K. Webb (eds.). San Francisco Estuary Institute, Oakland, California (October 2002).

${ }^{45}$ Minchin, D. 1997. The influence of the parasitic cirripede Sacculina carcini on its brachyuran host Carcinus maenas within its home range. Pages 76-80 in: Thresher, R.E. (ed.), Proceedings of the First International Workshop on the Demography, Impact and Management of Introduced Populations of the European Crab, Carcinus maenas. Technical Report No. 11. Centre for Research on Introduced Marine Pests, Hobart, Tasmania.

${ }^{46}$ Lafferty. K.D. 2002. Biological control of marine invasions. Biological Invasions in Aquatic

Ecosystems: Impacts on Restoration and Potential for Control. Proceedings of a Workshop. April 25, 1998. Sacramento, California. Cohen, A.N. and S.K. Webb (eds.). San Francisco Estuary Institute, Oakland, California, October 2002.

${ }^{47}$ Grosholz, Edwin and Gregory Ruiz (eds). 2002. Management Plan for the European Green Crab. Submitted to the Aquatic Nuisance Species Task Force.

${ }^{48}$ Wittenberg, Rüdiger and Matthew J.W. Cock. (eds.) 2001. Invasive Alien Species: A Toolkit of Best Prevention and Management Practices. CAB International, Wallingford, Oxon, UK, xvii-228. ${ }^{49}$ Wittenberg, Rüdiger and Matthew J.W. Cock. (eds.) 2001. Invasive Alien Species: A Toolkit of Best Prevention and Management Practices. CAB International, Wallingford, Oxon, UK, xvii-228. 
${ }^{50}$ Convention on Biological Diversity. 2005. Alien species that threaten ecosystems, habitats or species. United Nations Environment Programme.

http://www.biodiv.org/decisions/Default.aspx?dec=V I/23 Accessed November 8, 2005.

${ }^{51}$ Wittenberg, Rüdiger and Matthew J.W. Cock. (eds.) 2001. Invasive Alien Species: A Toolkit of Best Prevention and Management Practices. CAB International, Wallingford, Oxon, UK, xvii-228.

${ }^{52}$ Grosholz, Edwin and Gregory Ruiz (eds). 2002. Management Plan for the European Green Crab. Submitted to the Aquatic Nuisance Species Task Force.

${ }^{53}$ Ellis, S. 2006. California Department of Fish and Game, Habitat Conservation Planning Branch, Personal communication.

${ }^{54}$ Ferguson, R. 2000. The effectiveness of Australia's response to the Black Striped Mussel incursions in Darwin, Australia. A Report of the Marine Pest Incursion Management Workshop August 27-28 1999. Research report produced by the Department of Environment and Heritage.

${ }^{55}$ Bax, N.J. 1999. Eradicating a dreissenid from Australia. Dreissena! 10(3):1-5.

${ }^{56}$ Jensen, Douglas A and Jeffrey L. Gunderson. 2004. Effective Strategies that Work to

Prevent the Spread of Aquatic Invasive Species by Recreational Boaters. From the abstract proceedings of the $13^{\text {th }}$ International Conference on Aquatic Invasive Species, September 20 to 24, 2004.

${ }^{57}$ Sea Grant Nonindigenous Species website http://www.sgnis.org/ Accessed February 3, 2006.

${ }^{58}$ Aquatic Nuisance Species Task Force website http://www.anstaskforce.gov/default.php Accessed February 3, 2006.

${ }^{59} 100^{\text {th }}$ Meridian Initiative. http://www.100thmeridian.org/about100mi.htm Accessed August 3, 2005.

${ }^{60}$ Gunderson, J.L. and R.E. Kinnunen, eds. 2004. AIS-HACCP: Aquatic Invasive Species - Hazard Analysis and Critical Control Point Training Curriculum, $2^{\text {nd }}$ Edition. Minnesota Sea Grant Publications Number: MN SG-F11.

${ }^{61}$ Swaminathan, M.S. 2003. Bio-diversity: an effective safety net against environmental pollution. Environmental Pollution 126:287-291. 


\section{Antifouling Paints, Pollution and Bioinvasions - Ecology, Laws, Technologies, Practices, Conflicts and Resolutions}

This section will discuss impacts of antifoulants on water quality and related regulatory changes, alternative antifouling technologies and practices, and the potential for new policies intended to improve water quality to conflict with those aiming to control aquatic invasions. It will also suggest approaches that may help to achieve the dual goals of improving coastal water quality and reducing risks of introducing hull-borne invasive species.

\section{Antifouling Paints, Pollution and Bioinvasions}

Fouling growth on boat hulls creates drag, slowing sailboats and increasing power boat fuel consumption. Antifouling paints with heavy metals, such as tin and copper, have been used widely to slow fouling growth. The primary goal of antifouling paints is to prevent hull roughness, because fouling can increase vessels' resistance to movement through the water by $7 \%$ to $10 \%,{ }^{1}$ increasing fuel consumption in some cases by $30 \%{ }^{2}$ They also prevent water from penetrating and damaging the surface of wooden or fiberglass hulls.

A widely held belief presumes that antifouling paint technologies, such as those based on tributyl tin (TBT) or copper, will significantly reduce or eliminate hull fouling when combined with increased vessel speeds and cargo loading times. ${ }^{3}$ Some scientists have expressed concern that recent, decreased use of certain antifouling compounds, such as paints containing TBT, may increase fouling communities on certain vessels. ${ }^{4}$ The concurrent assumption has been that antifouling paints could also prevent hull-borne, invasive species introductions.

Although antifouling paints contribute to fouling control, recent studies indicate that hull fouling is still an important vector for invasive species. ${ }^{5678}$ In part this is because toxic antifouling paints simply retard fouling growth; they do not prevent it from becoming established on vessel hulls.

Significant settlements of biota can attach to hulls over some days and can be rapidly transported worldwide. ${ }^{9}$ Thus, periodic, mechanical, hull cleaning is needed even when antifouling paints are present. ${ }^{10}$

Also, despite the biocidal action of antifouling paints, some species have evolved resistance to copper-based antifouling paints. ${ }^{11}$ Resistance to heavy metals is a potentially important trait for introduced marine organisms, facilitating their successful invasion into disturbed natural communities. ${ }^{12}$ Unpublished research in San Francisco Bay suggests that invasive species are more tolerant of copper than native species. ${ }^{13}$ Russell and Morris have referred to this adaptation as, "ship fouling as an evolutionary process."14 Further research in Australia indicates that certain invasive species benefit from highly polluted environments and that human disturbance can facilitate the establishment and spread of invasive species in marine systems. ${ }^{15}$ These results suggest that improving coastal water quality by reducing pollution from antifouling paints and other sources could help native species that are less tolerant of heavy metal and other pollutants to resist invasions.

\section{Environmental Impacts of Heavy Metals from Antifouling Paints}

Metals that leach from antifouling paints can accumulate in the water of poorly flushed 
boat basins to levels that scientific research has shown will harm marine life.

Tributyl tin (TBT) is toxic to marine life at low concentrations. ${ }^{16}$ Research found that elevated TBT levels in the water column caused imposex (sex changes) in whelks, deformed oysters, and affected the food web by accumulating in lower organisms. ${ }^{17} 1819$ ${ }^{20}$ Severe imposex causes sterility ${ }^{21}$ with the result that local populations decrease dramatically or become extinct around ports. ${ }^{22} 23$ As early as 1975, significant and repeated disturbances occurred in Arcachon Bay oyster farms on the Atlantic Coast of France. TBT contamination of local breeding waters was responsible for stunted growth and failure to reproduce. ${ }^{25}$ Imposex has been documented in the wild for as many as 150 species of marine snails worldwide. ${ }^{26}$ The relationship of imposex to shipping traffic, poor recovery of affected populations in some areas, and widespread accumulation of butyltin residues in marine mammals led to calls to prohibit TBT on all vessels. ${ }^{27}$

Elevated copper levels affect growth, development, feeding, and other activity levels such as reproduction and survival at various life stages of mussels, oysters, scallops, crustaceans and sea urchins. High copper levels also change the types of phytoplankton that thrive in boat basins. ${ }^{28} 29$ 303132333435363738394041424344

Low levels of dissolved copper affect the sense of smell of juvenile coho salmon, which is critical for homing, foraging, and predator avoidance. Such effects could reduce chances of survival or reproduction of salmon populations in the Pacific Northwest ${ }^{45}$ and should be investigated for other fish species.

Some of the newer antifouling paints contain zinc, posing the risk that widespread adoption of such products could increase its concentration in marina waters to levels that are harmful to marine life. Elevated zinc levels may affect early stages of invertebrate growth and maturation and may be lethal. ${ }^{46}$ This impairment in growth could result from a reduction in available, metabolic energy, because zinc affects feeding, ${ }^{47}$ respiration, excretion, ${ }^{48}$ energy absorption ${ }^{49}$ and molting frequency ${ }^{50}$ in crustaceans. Elevated levels of zinc inhibit the chemoreceptors of marine animals, affecting their ability to feed and can affect the nervous system, disrupting prey capture and manipulation. ${ }^{51}$

\section{Antifouling Paint Regulation}

Environmental concerns led the International Maritime Organization to initiate a phased ban of TBT in antifouling paints that will be fully enforced in $2008^{52}$ The United States banned TBT in $1988 .^{53}$ With the international ban of TBT antifoulants, copper-based antifouling paints have become the standard and zinc-based products have also reached the market.

Copper-based boat bottom paints are legally registered pesticides ${ }^{54}$ that are facing new restrictions. Recently, California Regional Water Quality Control Boards (CRWQCB) and the United States Environmental Protection Agency (USEPA) identified dissolved copper levels that exceed federal and state standards in several, Southern California small craft harbors. ${ }^{55}{ }^{56}$ Section 303(d) of the federal Clean Water Act requires each state to maintain a list of impaired water bodies. ${ }^{57}$ The California Toxics Rule (CTR) defines levels of pollution that are low enough to protect marine life based on many scientific studies; currently the standard for dissolved copper is $3.1 \mu \mathrm{g} / \mathrm{l}$ (micrograms per liter). In other words, the ratio of dissolved copper to water 
can be no more than 3.1 parts of copper to 1 billion parts of water. ${ }^{58}$

A 2003 study by the Southern California Coastal Water Research Project concluded that $95 \%$ of dissolved copper released by antifouling paints occurs by passive leaching and $5 \%$ occurs during in-water hull cleaning. ${ }^{59}$ Following a Total Maximum Daily Load (TMDL) assessment and regulatory process, new regulations to reduce copper leaching from small craft antifouling paints by $76 \%$ over 17 years were approved in 2005 for Shelter Island Yacht Basin in northern San Diego Bay, where about 2000 boats are berthed. ${ }^{6061}$

As part of the Shelter Island Yacht Basin TMDL implementation plan, the California Regional Water Quality Control Board, San Diego Region (CRWQCB, SDR) will:

1. coordinate with government agencies having legal authority over the use of copper-based antifouling paint to protect water quality; and

2. regulate discharges of copper to Shelter Island Yacht Basin through issuance of Waste Discharge Requirements which could build upon pollution control programs developed by discharger organizations or the Port.

The dischargers will be required to monitor Shelter Island Yacht Basin waters and provide monitoring reports to the Regional Board to assess the effectiveness of measures that are used to reduce the level of copper in the water. ${ }^{62}$

Marina managers in Shelter Island Yacht Basin will need to determine the status of tenants' boat hulls in order to comply with new regulations. To do so, they will need to obtain verification from boat repair yards that have applied coatings to boats of the marinas' tenants. The verification would need to clarify the coatings' status with respect to copper leaching. Such documentation could be difficult to obtain for boats whose bottom coatings were applied outside the local area. Such new systems of accountability will impose additional burdens on these small businesses. $^{63}$

A TMDL assessment has been completed for Newport Bay in neighboring Orange County and another is underway at Marina Del Rey in Los Angeles County. ${ }^{64} 65$ In late 2005, the CRWQCB, SDR recommended placing other areas of San Diego Bay on the section 303(d) list of impaired water bodies due to elevated levels of dissolved copper. ${ }^{6}$ Thus, similar restrictions on leaching of copper from antifoulants may be extended to other parts of Southern California in coming years.

California agencies are considering a statewide approach to reducing copper pollution from antifouling paints. ${ }^{67} \mathrm{~A}$ California interagency workgroup and the USEPA are reevaluating registration of copper-based antifoulants. ${ }^{68} 69$ If impacts of copper-based antifouling paints on water quality are not adequately addressed after two years, the CRWQCB, SDR, in conjunction with the California State Water Resources Control Board, will work with all coastal CRWQBs to develop a state policy that addresses water quality impairments in marinas from copper-based antifouling paints. $^{70}$ The USEPA has proposed lowering the allowable level of dissolved copper in coastal waters from $3.1 \mu \mathrm{g} / \mathrm{l}$ to $1.9 \mu \mathrm{g} / \mathrm{l}^{71} 72$ In the United States, copper is the most common metal found at toxic concentrations in marina waters. ${ }^{73}$ If the agencies move forward with these actions, increased restrictions on copper-based, antifouling 
paints are likely to spread well beyond Southern California.

Copper-based antifouling paints have been banned for use by pleasure craft in the Netherlands. ${ }^{75} 76$ They are banned for pleasure craft on the east coast of Sweden and are restricted on the west coast of Sweden $^{77}$ and in Denmark. ${ }^{78}$

Some agency and boating industry representatives have expressed concern to us that new antifoulants with persistent toxicants could pose future environmental, regulatory and related socio-economic challenges similar to those now posed by TBT and copper. We suggest that careful consideration be given to these challenges before such alternatives are adopted.

\section{Alternative Fouling Control}

Current and developing regulations on TBT and copper antifoulants are stimulating major coating companies and new, smaller companies to develop innovative, nontoxic and other, alternative antifouling products. ${ }^{79}$ Many alternative bottom coatings with reduced environmental impacts are under development and a few have reached the market. As the demand for these alternatives increases and as more alternatives enter the market, their prices will likely fall.

\section{Nontoxic Bottom Coatings}

A nontoxic antifouling strategy combines a nontoxic boat bottom coating with a companion strategy. Examples of companion strategies include: frequently cleaning the coating; storing the boat out of water; and surrounding the boat with a slip liner and adding freshwater to discourage marine fouling growth. Because a nontoxic bottom coating will not slow fouling growth, it must be cleaned more often than a copper- based paint if the boat is stored in water. This is a new approach for managing fouling growth.

Some nontoxic bottom coatings are more expensive to apply than others. Nontoxic coatings may be applied to the gel coat on new boats or to a similar type of old nontoxic coating, depending on the product. However, most will not adhere to copperbased paints. Thus, old copper-based paint must be stripped from the hull before most nontoxic bottom coatings are applied.

Epoxy and ceramic-epoxy coatings are typically very durable, resistant to corrosion and abrasion, and can be scrubbed hard by divers. $^{80}$

Silicone or fouling release coatings typically have low surface energy, making it difficult for fouling growth to adhere to them. Field tests have found that fouling growth slides off when boats exceed the speed of 20 knots. ${ }^{81} 82$ On vessels that are often run at high speeds, hydrodynamic forces will tend to maintain the hull in a fouling free condition. $^{83}$

Siliconized epoxy and siloxane coating systems are similarly slippery, but are more durable than the typical silicone coating. ${ }^{84} 85$

Bottom wax is generally a seasonal coating with fouling release properties similar to those of silicone coatings. Bottom wax is typically clear and can be applied over old antifouling paint or to new surfaces. Like other nontoxic coatings, it must be cleaned often. Bottom wax can be very slippery. ${ }^{86} 87$

Boat owners must be sure to advise the boat repair yard if a slippery coating is on the hull. Slippery hull coatings increase the risk that the boat will slip out of the sling, when the boat is hauled, or slide off the blocks at the boat yard. 
Fluorinated polyurethane coatings provide corrosion protection and have properties that make it difficult for fouling to bond. Polyurethanes protect surfaces against chemicals, corrosion, wind and weather. Adding fluorine improves oil and water resistance of these coatings. They may be flexible and abrasion resistant. ${ }^{88} 89$

\section{Other Alternative Products}

Microbiological enzyme technology consists of microorganisms and enzymes embedded in an epoxy or polyurethane coating. It creates a biofilm on the boat's bottom that removes nutrients, eliminating the food supply of barnacles, slime and other soft growth. It also breaks down glues and polymeric structure of fouling organisms that are attempting to attach. ${ }^{90}$

Natural products from marine organisms can replace chemicals commonly used in antifouling coatings. ${ }^{91}$ Natural antifouling products have been isolated from a broad range of marine species, including bacteria, sponges, octocorals, bryozoans, ascidians and marine plants. ${ }^{92}$ Many sessile marine organisms are free from biofouling and produce metabolites with antifouling properties that protect them from colonization by fouling species or reduce competition for space in highly competitive environments. ${ }^{93}$ Extracts of sponges, sea squirts, algae, eelgrass and other species are being examined and tested for antifouling properties. Some developers are testing antifoulants with natural products. ${ }^{94} 9596$ For example, chili pepper extract has been added to antifouling paints to repel fouling organisms. The active ingredient is based on capsaicin, the natural oil which gives chili peppers their heat. It creates an unpleasant environment that deters organisms from attaching to the hull. ${ }^{97} 98$
Other alternative products may contain zinc or "booster" biocides that are organic and have a relatively short half-life. ${ }^{99}$ However, replacing one toxin (TBT or copper) with another may not be the best alternative. Major paint manufacturers are formulating antifouling coatings with one or more such biocides incorporated in cuprous oxide or in copper-free formulations. Phytochemicals and peroxide are also used as alternatives to prevent fouling. ${ }^{100} 101$

\section{Mechanical Cleaning Technologies}

Because nontoxic bottom coatings will not slow fouling growth, they must be cleaned more often than a metal-based paint if the boat is stored in water. For example, in San Diego, copper-based antifouling paints may need to be cleaned once every three to four weeks, but nontoxic coatings may need to be cleaned once every two to two-and-a-half weeks. Nontoxic epoxy and ceramic epoxy coatings should be scrubbed often. Much of the fouling growth on silicone coatings may be removed by a water spray or light brush. ${ }^{102} 103104$ Underwater hull cleaning is performed by divers either with hand tools or with a powered, rotating brush.

Hull cleaning stations allow the hull to be cleaned while the boat remains in the water. This method could allow hull cleaning wastes to be collected. Cleaning stations may be more convenient for some boat owners; others may prefer the convenience of contracting with hull cleaning divers to service their boats at regular intervals.

\section{Storage Technologies}

Slip liners serve as a companion strategy for nontoxic hull coatings. They are usually made from a woven, reinforced, ultravioletlight resistant, polyethylene fiber and are placed around the boat hull in the slip. Once 
the vessel is in place, saltwater inside the liner is diluted with freshwater to kill marine organisms. The outside of the liner should be cleaned annually. ${ }^{105} 106107$

Some concerns have been expressed by boat owners and marina managers. If the outside of the slip liner is not cleaned regularly, the weight of accumulated fouling may cause it to stretch and sag. ${ }^{108}$ Another potential concern is that the fabric of the slip liner could be torn. ${ }^{109}$ Boat owners using slip liners would have to become accustomed to entering and backing out of the liner. Finally, slip liners need supporting lines on four corners of the slip, which may be difficult if a boat is berthed in a shared, double slip. However, some boat owners have expressed their satisfaction with slip liners, for example a participant in our field demonstration of nontoxic hull coatings.

Boats may be stored above the water in the slip on a hoist or boat lift, ${ }^{110111}$ although this may not be feasible in some marinas. They may also be stored on land on trailers or in "boat barns." Antifouling paint may not be necessary if the vessel is stored out of water. In cold-weather areas, boats are typically stored out of water during the winter.

\section{Independent Testing}

Many new products are being developed and some have reached the market. Some boaters are trying these products, especially in areas under scrutiny for elevated copper levels due to antifouling paints. Testing that is independent of the manufacturers is needed to confirm the efficacy, durability, and cost-effectiveness of alternatives to copper-based boat bottom paints under different climatic and operating conditions. No single alternative, nontoxic or other, antifouling strategy will suit every vessel or location. Water quality, fouling and invasive species control, cost and technical feasibility must be considered in selecting an antifouling strategy.

Although some alternatives show promise for managing fouling growth, their efficacy must be demonstrated under a wider variety of conditions. Costs to buy and use them are expected to exceed those for metal-based paints, although the greater longevity of some products may make them cost effective. $^{112} 113$

\section{Economics of Switching to Nontoxic Bottom Coatings}

In 2002, the University of California Sea Grant Extension Program (UCSGEP) in San Diego and the University of California, San Diego Department of Economics conducted a study of economic incentives for boaters to switch to nontoxic bottom coatings. Based on data presented in Table 2, they found that the extended lifespan of durable, nontoxic epoxy coatings could create savings that exceeded the increased maintenance and application costs for these coatings.

Most San Diego Bay boat owners replace their boat's copper antifouling paint every two or three years because the cuprous oxide has been depleted. Some nontoxic coatings may last up to 12 years because they are durable and do not depend on the leach rate of cuprous oxide. However, nontoxic coatings need to be cleaned about twice a month versus once a month for copper-based coatings.

Boat repair yard representatives estimated that boats need to be stripped of built-up layers of copper paint every 12 to 20 years (average of 15 years). Because most nontoxic coatings will not adhere to copperbased paint, it is most cost effective to apply 
a nontoxic coating to new boats, which have no antifouling paint, or to boats that are ready to be stripped of old paint. ${ }^{114}$

Table 2. Bottom coating application and maintenance factors for a typical, 40-foot long boat. ${ }^{115}$

\begin{tabular}{|c|c|c|}
\hline Cost Factor & $\begin{array}{l}\text { Copper } \\
\text { Paint }\end{array}$ & $\begin{array}{l}\text { Nontoxic Epoxy } \\
\text { Coating }\end{array}$ \\
\hline $\begin{array}{l}\text { Haulout, } \\
\text { Preparation } \\
\text { and } \\
\text { Application }\end{array}$ & $\begin{array}{l}\$ 30 / \text { foot } \\
\text { (typical) }\end{array}$ & $\begin{array}{l}\$ 30 / \text { foot or } \\
\$ 50 / \text { foot }\end{array}$ \\
\hline $\begin{array}{l}\text { Reapplication } \\
\text { Frequency }\end{array}$ & $\begin{array}{l}\text { Every } 2.5 \\
\text { years }\end{array}$ & $\begin{array}{l}\text { Every } 5 \text { or } 10 \\
\text { years }\end{array}$ \\
\hline $\begin{array}{l}\text { Stripping } \\
\text { Cost }\end{array}$ & \$120/foot & $\$ 120 /$ foot \\
\hline $\begin{array}{l}\text { Stripping } \\
\text { Decision }\end{array}$ & $\begin{array}{l}\text { If hull has } \\
\text { blisters or } \\
\text { paint build- } \\
\text { up }\end{array}$ & $\begin{array}{l}\text { If convert from } \\
\text { copper-based or } \\
\text { other "unlike" } \\
\text { paint }\end{array}$ \\
\hline $\begin{array}{l}\text { Stripping } \\
\text { Frequency } \\
\text { (On average } \\
15 \text { years = } \\
\text { every } 6^{\text {th }} \text { time } \\
\text { if reapply } \\
\text { paint every } \\
2.5 \text { years) }\end{array}$ & $\begin{array}{l}\text { Every } 15 \\
\text { years on } \\
\text { average }\end{array}$ & $\begin{array}{l}\text { Every } 30 \text { years (if } \\
\text { reapply coating } \\
\text { every } 5 \text { years); } \\
\text { Every } 60 \text { years (if } \\
\text { reapply coating } \\
\text { every } 10 \text { years) }\end{array}$ \\
\hline $\begin{array}{l}\text { Hull } \\
\text { Cleaning } \\
\text { Cost }\end{array}$ & $\begin{array}{l}\$ 1.00- \\
\$ 1.25 / \text { foot }\end{array}$ & $\$ 1.00-\$ 1.25 /$ foot \\
\hline $\begin{array}{l}\text { Hull } \\
\text { Cleaning } \\
\text { Frequency }\end{array}$ & $\begin{array}{l}14 \\
\text { times/year }\end{array}$ & 22 times/year \\
\hline
\end{tabular}

\section{Field Demonstration of Nontoxic Bottom Coatings}

The UCSGEP conducted a field demonstration of nontoxic epoxy, ceramicepoxy and silicone-rubber bottom coatings on six boats in San Diego Bay during 20022003. Divers reported on coating condition, fouling growth and diver effort levels, and type of tool used each time they cleaned the hulls. Cleaning more frequently prevented fouling growth from accumulating to high levels. In turn, this allowed divers to use less aggressive tools, spend less time cleaning, and exert less effort. Frequent cleaning may thus be expected to extend the life of the coating, reduce the cost of each cleaning and reduce wear and tear on hull cleaners. Using a power cleaning tool allowed divers to use a less aggressive cleaning surface and exert less effort, compared to hand-held tools. These points are especially important when water is warmer, because fouling growth accumulates faster then. ${ }^{116}$

During the demonstration project, the boats were cleaned according to a schedule set by their owners in consultation with their hull cleaning companies. The boats with epoxy or ceramic-epoxy were cleaned on average every 15 to 18 days; the boats with the silicone-rubber coating were cleaned on average every 7 to 12 days.

The epoxy and ceramic-epoxy coatings were more durable and may be more cost effective in the long term, if the boat does not need to be hauled frequently for other maintenance purposes. They are also durable barriers to water penetration of the hull material. The silicone-rubber coating was preferred by boat owners who liked to race and were willing to invest in very frequent cleaning and annual replacement. The epoxy and ceramic-epoxy coatings appeared to be a good choice for boat owners who want a nontoxic coating that may last long enough to compensate for costs incurred with more frequent cleaning and converting from a copper-based coating. ${ }^{117}$

\section{Policy Instruments}

According to the economic study, the following policy instruments may be useful for policymakers to consider in resolving the problem of copper pollution in boat basins, while maintaining the economic viability of boating. Requiring that new boats use 
nontoxic coatings would begin the phase-out of copper and save boat owners money in the long-term because they would not have to reapply copper paint every two to three years. Announcing a future ban on the use of copper paint would raise the value of boats with nontoxic coatings and strongly influence decisions on whether to repaint with a copper or nontoxic coating when old paint is being stripped from a boat's hull. Relative costs of alternative products and metal-based antifouling paints will likely be affected by additional bans or restrictions on copper-based antifouling paints. ${ }^{118}$

Costs to purchase and apply nontoxic coatings may fall as the demand increases, as more applicators are trained in technical considerations, and as more products enter the market. Conversion costs should fall as nontoxic and other alternative coatings are developed that can be applied directly to copper-based bottom paints.

\section{Social Impacts of Using Nontoxic and Other Alternative Bottom Coatings}

Boat owners who use nontoxic bottom coatings would have to become accustomed to more frequent hull cleaning and associated costs. They will need to schedule periodic maintenance checks even though durable nontoxic coatings will not require frequent replacement. Boat owners would need to advise boat repair yards, if their boats have slippery coatings, such as silicone, siliconized epoxy, siloxane or bottom wax.

Boat yard operators would need to learn special handling procedures for boats with these coatings. Nontoxic and other alternative coating manufacturers would need to train staff of boat repair yards in special application procedures.
Hull cleaners would need to learn schedules, techniques and tools that are appropriate for nontoxic and other alternative coatings. For example, some hull cleaners in San Diego use powered rotary brushes to maintain the durable epoxy coatings. Other coatings may require softer cleaning tools.

\section{Potential Conflicts between Policies to Reduce Antifoulant Pollution and to Control Hull-Borne Invasive Species}

The potential statewide ban of copper-based antifouling paints may exacerbate invasions as the toxicity of vessel hulls declines and water quality improves in coastal ports and harbors. On the other hand, native species may be more resistant to invasions if water quality improves. Coordination is needed to resolve conflicts between policies to control hull-borne, aquatic invasive species in hull fouling and reduce antifouling paint pollution. Research could help to find feasible and cost-effective solutions. More information on the relationship between antifouling pollution and invasive species can be found in Section V of this report.

As noted earlier in this report, the entire California coast has experienced some level of invasion by species not native to the state or not native to the area of the coast where they have been discovered. In many cases, invasive species introduced as hull fouling have caused ecological damage and economic effects involving millions of dollars worth of structural damage.

Nontoxic coatings do not retard fouling growth, so they need to be cleaned every two to three weeks. Section 101 (3) (B) (iv), (v) of the United States Senate ${ }^{119}$ and House $^{120}$ versions of the National Aquatic Invasive Species Act of 2005 suggests guidelines on best management practices to eliminate or minimize aquatic invasive 
species (AIS) transport by vessels. The guidelines include proper use of antifouling coatings and, to the maximum extent practicable, collection and proper disposal of debris from hull cleaning. Section 305 prescribes "an education, outreach and training program directed toward marinas and marina operators regarding ... (III) encouraging regular hull cleaning and maintenance; avoiding in-water hull cleaning” for watercraft at marinas.

According to hull cleaners in the San Diego area, the technology to collect fouling growth during in-water cleaning is not suitable for boats normally kept in saltwater. (The United States Navy and the New Zealand Diving and Salvage Ltd. are developing in-water hull cleaning and fouling-waste containment systems for ships. $^{121} 122123$ )

Table 3. Annual, In-Water, Hull-Cleaning Costs for Copper Paints and Nontoxic Coatings on a Typical, 40-foot Boat

\begin{tabular}{|l|l|l|}
$\begin{array}{l}\text { Hull } \\
\text { Coating } \\
\text { Type }\end{array}$ & $\begin{array}{l}\text { In-Water Hull } \\
\text { Cleaning Per } \\
\text { Service }^{\mathbf{1 2 4}}\end{array}$ & $\begin{array}{l}\text { In-Water Hull } \\
\text { Cleaning Per } \\
\text { Year }\end{array}$ \\
\hline $\begin{array}{l}\text { Copper } \\
\text { Paint }\end{array}$ & $\begin{array}{l}\$ 1.25 / \text { foot } \times 40 \\
\text { feet }=\$ 50\end{array}$ & $\begin{array}{l}\$ 50 \times 13 \\
\text { cleanings }=\$ 650\end{array}$ \\
\hline $\begin{array}{l}\text { Nontoxic } \\
\text { Coating }\end{array}$ & $\begin{array}{l}\$ 1.25 / \text { foot } \times 40 \\
\text { feet }=\$ 50\end{array}$ & $\begin{array}{l}\$ 50 \times 26 \\
\text { cleanings }= \\
\$ 1300\end{array}$ \\
\hline
\end{tabular}

Table 4. Annual, Haul-Out, Hull-Cleaning Costs for Copper Paints and Nontoxic Coatings on a Typical, 40-foot Boat

\begin{tabular}{|c|c|c|}
\hline $\begin{array}{l}\text { Hull } \\
\text { Coating } \\
\text { Type }\end{array}$ & $\begin{array}{l}\text { Haul-Out/Hull } \\
\text { Cleaning Per } \\
\text { Service }^{125}\end{array}$ & $\begin{array}{l}\text { Haul-Out/Hull } \\
\text { Cleaning Per } \\
\text { Year }\end{array}$ \\
\hline $\begin{array}{l}\text { Copper } \\
\text { Paint }\end{array}$ & $\begin{array}{l}\$ 10 / \text { foot } x 40 \\
\text { feet }+\$ 60= \\
\$ 460\end{array}$ & $\begin{array}{l}\$ 460 \times 13 \\
\text { cleanings = } \\
\$ 5,980\end{array}$ \\
\hline $\begin{array}{l}\text { Nontoxic } \\
\text { Coating }\end{array}$ & $\begin{array}{l}\$ 10 / \text { foot } \times 40 \\
\text { feet }+\$ 60= \\
\$ 460\end{array}$ & $\begin{array}{l}\$ 460 \times 26 \\
\text { cleanings = } \\
\$ 11,960\end{array}$ \\
\hline
\end{tabular}

Under the proposed Act, boats with nontoxic coatings would have to be hauled in order to collect and dispose of fouling growth. Hauling their boats twice a month for cleaning would create considerable burdens of cost and time for recreational boaters who use nontoxic coatings, as shown in Tables 3 and 4.

On the other hand, using copper-based antifouling paints to control invasive species can create water quality problems in crowded boat basins.

\section{Analysis of Means to Reduce Policy Conflicts}

We suggest that boaters who travel long distances are most likely to encounter and transport invasive species on the hulls of their boats. Table 1 in Section IV ${ }^{126}$ indicates that from two percent to seven percent of boaters in California's coastal counties take frequent trips over 100 miles from home, depending on the region of the coast. Their boats might be better candidates for copper-based or less toxic antifouling paints as opposed to nontoxic coatings. Because they are relatively few in number and spend less time in the home marina, they would discharge less toxicant to confined waters.

Boaters who do not travel long distances are less likely to encounter potentially invasive species. Table 1 in Section IV ${ }^{127}$ indicates that about one-half of all boaters in California's coastal counties took no trips over 100 miles from home in 2000. Because they are large in number and spend more time in the home marina, they likely contribute the lion's share to elevated copper levels. Thus, the most reduction in pollution and invasive species risk could be achieved if such boats used nontoxic coatings that require frequent cleaning. 
Even copper-based antifoulants slow, rather than prevent, fouling. Thus, invasive species transport could be prevented by cleaning all boat hulls before leaving for distant areas or events where boats from many areas are likely to congregate. Boats returning to their home ports from a long-distance cruise or boating event could carry potential invaders, so it would be wise to clean their hulls before heading home. Heavily fouled boats returning from a long-distance trip pose the greatest risk of carrying AIS. It may be appropriate to clean hulls of such boats before they enter the harbor. Alternatively, it may be appropriate to haul such boats immediately upon entry to the harbor, clean their hulls, contain the fouling debris and dispose it in a landfill.

Marina and yacht club operators could create incentives for boaters to use nontoxic coatings by putting those whose vessels have nontoxic coatings at the top of the waiting list for slips. However, as in harbors at Santa Cruz and Brisbane, California many boaters on waiting lists do not yet have boats and so would not likely respond to such an incentive. ${ }^{128}$ Other policy instruments that may be useful for policy makers to consider in resolving the problem of copper pollution in boat basins while maintaining the economic viability of boating can be found in Section VIII of this report.

Educating boat owners on the impacts of AIS, for example the damage to native habitat and potential economic damage, may motivate them to follow guidelines for preventing AIS introductions.

The coating industry is actively engaged in developing nontoxic and less toxic coatings. ${ }^{129}$ If copper-based antifouling paints are banned or restricted, the demand for nontoxic coatings will increase. Greater demand will further stimulate research, development and marketing of more effective, nontoxic and less toxic coatings. As demand increases, nontoxic and less toxic coating prices are likely to fall due to competition between manufacturers, economies achieved by producing larger quantities and efficiencies achieved as boat maintenance businesses acquire equipment and training needed to apply them.

We collaborated with California State Lands Commission in May 2005 to convene a Workshop on Managing Hull Transport of Aquatic Invasive Species. The purpose was, first, to educate stakeholders on the issues of water quality related to antifouling paints and of preventing hull transport of invasive species. Stakeholders were then asked to recommend means to address these issues. Participants included ship and boat owners, managers of ports, harbors, marinas, and yacht clubs, ship and boat repair/maintenance business operators, academics, and representatives of government agencies and environmental organizations. Workshop recommendations appear in Appendix F of this report; the full Proceedings are available from the authors of this report, from California Sea Grant College Program at (858) 534-4446 and on the Internet at http://seagrant.ucdavis.edu.

Continued communication between government agencies and stakeholders will increase feasibility and effectiveness of policies to prevent hull-borne invasive species transport, while protecting coastal water quality.

\section{References}

\footnotetext{
${ }^{1}$ Lamb, T. 1981. "Measuring fishing vessel energy performance and ways to improve it." SNAME/NOAA Fishing Industry Energy Conservation Conference, Seattle, WA.

${ }^{2}$ Younqlood, J.P., L. Andruzzi, W. Senaratne, C.K. Ober, J.A. Callow, J.A. Finlay, M.E. Callow. 2003. New materials for marine biofouling resistance and
} 
release: semi-fluorinated and pegylated block copolymer bilayer coatings. Polymeric Materials Science and Engineering 88:608-609

${ }^{3}$ Coutts, A.D.M. and M.D. Taylor, 2001. An Investigation of High Risk Areas on The Hulls of Merchant Vessels for the Translocation of Exotic Fouling Organisms, Cawthron Institute. Proceedings of the Second International Conference on Marine Bioinvasions, New Orleans, La., April 9-11, 2001, pp. 25-27.

${ }^{4}$ Nehring, S. 2001. After the TBT era: alternative antifouling paints and their ecological risks. Senckenbergiana Maritima 31:341-351.

${ }^{5}$ Rainer, S.F. 1995. Potential for the introduction and translocation of exotic species by hull fouling: A preliminary assessment. Commonwealth Scientific and Industrial Research Organization (CSIRO) Centre for Research on Introduced Marine Pests. Technical Report 1. Hobart, Australia.

${ }^{6}$ Coutts, A.D.M. 1999. Hull fouling as a modern vector for marine biological invasions: investigation of merchant vessels visiting northern Tasmania. Unpublished Masters Thesis, Australian Maritime College, Launceston, Tasmania, Australia. 283 pp.

${ }^{7}$ Hewitt, C.L., M.L. Campbell, R.E. Thresher, and R.B. Martin, eds. 1999. Marine biological invasions of Port Phillip Bay, Victoria. Centre for Research on Introduced Marine Pests, Technical Report 20, 344pp. Commonwealth Scientific and Industrial Research Organization (CSIRO). Hobart, Australia. ${ }^{8}$ Hewitt, C.L. and M.L. Campbell. 2001. The Australian distribution of the introduced sphaeromatid isopod Paracerceis sculpta (Homes 1904). Crustaceana 78: 925-936.

${ }^{9}$ Minchin, D. and S. Gollasch. 2003. Fouling and ship's hulls: how changing circumstances and spawning events may result in the spread of exotic species. Biofouling 19:111-122.

${ }^{10}$ Johnson, L.T. and J.A. Miller. 2002. What you need to know about nontoxic antifouling strategies for boats. California Sea Grant College Program Report No. T-049.

${ }^{11}$ Hall, A. 1981. Copper accumulation in coppertolerant and non-tolerant populations of the marine fouling alga, Ectocarpus siliculosus (Dillwyn) Lyngbye. Botanica Marina 24:223-228.

${ }^{12}$ Piola, R.F. and E.L. Johnston. 2005. Differential tolerance to metals among populations of the introduced bryozoan Bugula neritina. Marine Biology (Published Online, November 2005).

${ }^{13}$ Crooks, J. 2005. Oral commentary. Vessel Fouling Technical Advisory Group, October 13, 2005: Meeting Summary. California State Lands Commission, Sacramento, CA.
${ }^{14}$ Russell, G. and O.P. Morris. 1973. Ship fouling as an evolutionary process, Proceedings of the $3^{\text {rd }}$ International Congress of Marine Corrosion and Fouling: 719-730, Washington, DC, 1972.

${ }^{15}$ Piola, R.F. and E.L. Johnston. 2005. Differential tolerance to metals among populations of the introduced bryozoan Bugula neritina. Marine Biology (Published Online, November 2005).

${ }^{16}$ Alzieu, C. 1996. Biological effects of tributyltin on marine organisms. In Tributyltin: Case study of an environmental contaminant, ed. S.J. de Mora, pp. 139-166. Cambridge University Press, Cambridge. ${ }^{17}$ de Mora, S.J. (ed.) 1996. Tributyltin: Case Study of an Environmental Contaminant. Cambridge University Press, Cambridge, UK.

${ }^{18}$ Son, M.H. and R.N. Hughes. 2000. Relationship between imposex and morphological variation of the shell in Nucella lapillus (Gastropoda: Thaidadae). Estuarine, Coastal and Shelf Science 50: 599-606. ${ }^{19}$ Bryan, G.W., P.E. Gibbs, L.G. Hummerstone, G.R. Burt. 1986. The decline of the gastropod Nucella lapillus around South-West England: evidence for the effect of tributyltin from antifouling paints. Journal of Marine Biology Association of the United Kingdom 66:611-640.

${ }^{20}$ Bryan, G.W., P.E. Gibbs, G.R. Burt, and L.G. Hummerstone. 1987. The effects of tributyltin (TBT) accumulation on adult dog whelks, Nucella lapillus: long term field and laboratory experiments. Journal of the Marine Biology Association of the United Kingdom 67:525-544.

${ }^{21}$ Gibbs, P.E., and G.W. Bryan. 1986. Reproductive failure in populations of the dogwhelk, Nucella lapillus, caused by imposex induced by tributyltin from antifouling paints. Journal of the Marine Biology Association of the UK 66:767-777.

${ }^{22}$ Evans, S.M., S.T. Hawkins, J. Porter, A.M. Samosir. 1994. Recovery of dogwhelk populations on the Isle of Cumbrae, Scotland following legislation limiting the use of TBT as an antifoulant. Marine Pollution Bulletin 28:15-17.

${ }^{23}$ Harding, M.J.C., Rodger, G.K., I.M. Davies, and J.J. Moore. 1997. Partial recovery of the dogwhelk (Nucella lapillus) in Sullom Voe, Shetland from tributyltin contamination. Marine Environmental Research 44:285-304.

${ }^{24}$ Crothers, J.H. 1998. The size and shape of dogwhelks, Nucella lapillus (L.) recolonising a site formerly polluted by tributyltin (TBT) in antifouling paint. Journal of Molluscan Studies 64:127-129.

${ }^{25}$ Alzieu, C. 1998. Tributyl tin: case study of a chronic contaminant in the coastal environment. Ocean and Coastal Management 40:23-36.

${ }^{26}$ Vos, J.G., E. Dybing, H.A. Greim, O. Landefoged, C. Lambre, and J.V. Tarazona, I. Brandt, and A.D. 
Vethaak. 2000. Health effects of endocrine-disrupting chemicals on wildlife, with special reference to the European situation. Critical Reviews in Toxicology 30(1):71-133.

${ }^{27}$ Santillo, D., P. Johnston, and W.J. Langston. 2001. Tributylyin (TBT) antifoulants: a tale of ships, snails and imposex. Late lessons from early warnings: the precautionary principle 1896-2000. http://reports.eea.eu.int/ Accessed July 5, 2005. ${ }^{28}$ Calabrese, A., MacInnes, J. R., Nelson, D. A., Greig, R. A., and P. P. Yevich. 1984. Effects of Long-term Exposure to Silver or Copper on Growth, Bioaccumulation and Histopathology in the Blue Mussel Mytilus edulis. Marine Environmental Research, 11:253-274.

${ }^{29}$ Coglianese, M. P. and M. Martin. 1981. Individual and Interactive Effects of Environmental Stress on the Embryonic Development of the Pacific Oyster, Crassostrea gigas. I. The Toxicity of Copper and Silver. Marine Environmental Research, 5:13-27. ${ }^{30}$ Gould, E., Thompson, R. J., Buckley, L. J., Rusanowsky, D., and G. R. Sennefelder. 1988. Uptake and Effect of Copper and Cadmiumon the Gonad of the Scallop Placopecten magellanicus: Concurrent Metal Exposure. Marine Biology 97:217223.

${ }^{31}$ Johns, D.M. and D.C. Miller. 1982. The use of bioenergetics to investigate the mechanisms of pollutant toxicity in crustacean larvae. In: Vernberg, W.B., A. Calabrese, F.B. Thurberg, and F.J. Vernberg (Eds.). Physiological Mechanisms of Marine Pollutant Toxicity, Academic Press, New York, pp. 261-288.

${ }^{32}$ Katz, C. 1998. Seawater Polynuclear Aromatic Hydrocarbons and Copper in San Diego Bay. Technical Report 1768. Space and Naval Systems Center (SPAWAR). San Diego, CA.

${ }^{33}$ Kime, D.E. 1995. The effects of pollution on reproduction in fish. Reviews in Fish Biology and Fisheries 5:52-96.

${ }^{34}$ Krett Lane, S. M. 1980. Productivity and Diversity of Phytoplankton in Relation to Copper in San Diego Bay. Technical Report 533. Naval Oceans Systems Center.

${ }^{35}$ Krishnakumar, P. K., Asokan, P. K., and V. K. Pillai. 1990. (Abstract) Physiological and CellularResponses to Copper and Mercury in the Green Mussel Perna-Viridis (Linnaeus). Aquatic Toxicology, 18(3):163-173.

${ }^{36}$ La Breche, T.M.C., A.M. Dietrich, D.L. Gallagher, and $\mathrm{M}$. Shepherd. Copper toxicity to larvel Mercenaria mercenaria (hard clam). Environmental Toxicology and Chemistry 21(4):760-766.
${ }^{37}$ Lee, H. H. and C. H. Xu. 1984. Effects of Metals on Sea Urchin Development: A Rapid Bioassay. Marine Pollution Bulletin 15:18-21.

${ }^{38}$ Lussier, S. M., J. H. Gentile, and J. Walker. 1985. Acute and Chronic Effects of Heavy Metals and Cyanide on Mysidopsis bahia (Crustacea: Mysidacea). Aquatic Toxicology 7:25-35. ${ }^{39}$ MacDonald J.M., Shields J.D., and R. K. ZimmerFaust. 1988. Acute toxicities of eleven metals to early life-history stages of the yellow crab Cancer anthonyi. Marine Biology 98:201-207.

${ }^{40}$ Martin, M., K.E. Osborn, P. Billig, and N. Glickstein. 1981. Toxicities of Ten Metals to Crassostrea gigas and Mytilus edulis Embryos and Cancer magister Larvae. Marine Pollution Bulletin 12:305-308.

${ }^{41}$ Redpath, K. J. and J. Davenport. 1988. The Effect of Copper, Zinc, and Cadmium in the Pumping Rate of Mytilus edulis L. Aquatic Toxicology 13:217-226. ${ }^{42}$ Redpath, K. J. 1985. Growth Inhibition and Recovery in Mussels (Mytilus edulis) Exposed to Low Copper Concentrations. Journal of the Marine Biological Association of the United Kingdom 65(2):421-31.

${ }^{43}$ Stromgren, T. and V. Nielsen. 1991. "Spawning Frequency, Growth, and Mortality of Mytilus edulis Larvae, Exposed to Copper and Diesel Oil,” Aquatic Toxicology, 21:171-180.

${ }^{44}$ VanderWeele, D.A. 1996. The Effects of Copper Pollution on the Bivalve, Mytilus edulis and the Amphipod, Grandidierella japonica in the Shelter Island Yacht Basin, San Diego Bay, California. M.S. Thesis. San Diego State University, San Diego, CA. ${ }^{45}$ Baldwin, D., J. Labenia, B, French, and N. Scholz. 2004. The impacts of dissolved copper on olfactory function in juvenile coho salmon. NOAA Northwest Fisheries Science Center.

http://www.nwfsc.noaa.gov/research/divisions/ec/eco tox/fishneurobiology/copperimpacts.cfm Accessed August 19, 2005.

${ }^{46}$ Conradi, M.. and M.H. Depledge. 1999. Effects of zinc on the life-cycle, growth and reproduction of the marine amphipod Corophium volutator. Marine Ecological Progress Series 176:131-138

${ }^{47}$ Weeks, J. 1993. Effects of dietary copper and zinc concentrations on feeding rates of two species of talitrid amphipods (Crustacea). Bulletin of Environmental Contamination and Toxicology 50:883-890.

${ }^{48}$ Correa, M. 1987. Physiological effects of metal toxicity on the tropical freshwater shrimp Macrobrachium carcinus (Linneo, 1758). Environmental Pollution 45:149-155. 
${ }^{49}$ Naylor, C., Maltby, L., and P. Calow. 1989. Scope for growth in Gammarus pulex, a freshwater benthic detritivore. Hydrobiologia 188/189:517-523.

${ }^{50}$ Drobne, D. and J. Strus. 1996. Moult frequency of the isopod Porcellio scaber, as a measure of zinccontaminated food. Environmental Toxicology and Chemistry 15(2):126-130.

${ }^{51}$ Marcos, H. S. S., N. Troca da Cunha and A. Bianchini. 2000. Effects of copper and zinc on growth, feeding and oxygen consumption of Farfantepenaeus paulensis postlarvae (Decapoda: Penaeidae). Journal of Experimental Marine Biology and Ecology 247:233-242.

${ }^{52}$ International Maritime Organization. 2004. Marine Environment: Antifouling Systems.

http://www.imo.org/ Accessed October 17, 2005.

5352 Federal Register 37,518 (Oct. 7, 1987).

${ }^{54}$ California Department of Pesticide Regulation. 2004. California Code of Regulations (Title 3. Food and Agriculture) Division 6. Pesticides and Pest Control. http://www.cdpr.ca.gov/docs/inhouse/calcode/020101 .html Accessed October 17, 2005.

${ }^{55}$ California Regional Water Quality Control Board, San Diego Region. 2004. Total Maximum Daily Load for Dissolved Copper in Shelter Island Yacht Basin, San Diego Bay, Revised Public Review Draft. http://www.waterboards.ca.gov/sandiego/tmdls/tmdl_ files/shelter\%20island/SIYB\%20TMDL\%20Tech\%2 0Rept\%2010-14-04\%20rev1.pdf

${ }^{56}$ United States Environmental Protection Agency. 2002. Total Maximum Daily Loads for Toxic Pollutants: San Diego Creek and Newport Bay, CA. U.S. EPA Region 9, San Francisco, CA. http://www.epa.gov/Region9/water/tmdl/nbay/summ ary0602.pdf

${ }^{57}$ Clean Water Act Title III - Standards and Enforcement (Sections 301-320)

<http://www.epa.gov/region5/water/cwa.htm> Accessed October 17, 2005.

${ }^{58}$ U.S. Environmental Protection Agency. 2000. Establishment of Numeric Criteria for Priority Pollutants for the State of California; California Toxics Rule.

http://www.epa.gov/OST/standards/ctrindex.html Accessed October 17, 2005.

${ }^{59}$ Schiff, K., D. Diehl, and A. Valkirs. 2003. Copper emissions from antifouling paint on recreational vessels. SCCWRP Technical Report \#405. Southern California Coastal Water Research Project, Westminster, CA.

${ }^{60}$ California Regional Water Quality Control Board, San Diego Region. 2004. Total Maximum Daily Load for Dissolved Copper in Shelter Island Yacht Basin, San Diego Bay, Revised Public Review Draft. http://www.waterboards.ca.gov/sandiego/tmdls/tmdl_ files/shelter\%20island/SIYB\%20TMDL\%20Tech\%2 0Rept\%2010-14-04\%20rev1.pdf

${ }^{61}$ California State Water Resources Control Board. 2005. State Water Board Resolution No. 2005-0071. Approving an Amendment to the Water Quality Control Plan for the San Diego Region to Establish a Total Maximum Daily Load (TMDL) for Dissolved Copper in Shelter Island Yacht Basin.

http://waterboards.ca.gov/resdec/resltn/2005/rs20050071.pdf Accessed October 18, 2005.

${ }^{62}$ California Regional Water Quality Control Board, San Diego Region. 2004. Total Maximum Daily Load for Dissolved Copper in Shelter Island Yacht Basin, San Diego Bay: Technical Report February 9, 2005.

http://www.waterboards.ca.gov/sandiego/tmdls/tmdl_ files/shelter\%20island/final\%20docs/SIYB\%20Tech \%20Rept\%20Final\%202-05.pdf. Accessed January 26, 2006.

${ }^{63}$ Pennell, D. 2005. Personal communication. Shelter Island Marina, San Diego, CA. October 20, 2005.

${ }^{64}$ U.S. Environmental Protection Agency. 2002.

Total Maximum Daily Loads for Toxic Pollutants: San Diego Creek and Newport Bay, CA. U.S. EPA Region 9, San Francisco, CA. http://www.epa.gov/Region9/water/tmdl/nbay/summ ary0602.pdf Accessed October 17, 2005.

${ }^{65}$ California Regional Water Quality Control Board, Los Angeles Region. 2005. Total Maximum Daily Load for Toxic Pollutants in Marina Del Rey Harbor. http://www.waterboards.ca.gov/losangeles/html/meet ings/tmdl/marina_del_rey/toxics/05_0803/MdR\%20T oxics\%20Staff\%20Report.pdf Accessed October 17, 2005.

${ }^{66}$ Draft Staff Report Supporting the Recommended Revisions to the Clean Water Act Section 303(d) List. September 2005. California Regional Water Quality Control Board Region 9. Fact Sheets Supporting Revision of the Section 303(d) List. (Volume III San Diego Region) http://www.swrcb.ca.gov/tmdl/docs/303d_update/r9_ v3.pdf Accessed October 17, 2005.

67 San Diego Unified Port District Board of Commissioners. April 26, 2005. Agenda Item 14: Recommendation to pursue a statewide and national approach to regulating copper discharges from marine antifoulant paint and approve a concept plan for reducing copper antifoulant discharges in Shelter Island Yacht Basin.

${ }^{68}$ Singhasemanon, N. 2005. Copper Antifouling Paint Sub-Workgroup 5/26/05 Meeting Notes. California Department of Pesticide Regulation, Sacramento, CA. 
${ }^{69}$ Singhasemanon, N. 2005. Copper Antifouling Paint Sub-Workgroup 5/26/05 Meeting Notes. June 13, 2005. 6 p.

${ }^{70}$ State Water Board Resolution No. 2005-0071. 2005. Approving an Amendment to the Water Quality Control Plan for the San Diego Region to Establish a Total Maximum Daily Load (TMDL) for Dissolved Copper in Shelter Island Yacht Basin. http://www.waterboards.ca.gov/resdec/resltn/2005/rs 2005-0071.pdf Accessed October 18, 2005.

${ }^{71}$ United States Environmental Protection Agency. 2004. Draft Updated Water Quality Criteria for Copper Fact Sheet.

http://www.epa.gov/waterscience/criteria/copper/draf tupdatefs.htm Accessed November 10, 2005.

${ }^{72}$ Cruz, L. 2005. Environmental Protection Agency. Office of Water: Health and Ecological Criteria Division, personal communication.

${ }^{73}$ NCDEM. 1990. North Carolina Coastal Marinas: Water Quality Assessment. North Carolina Division of Environmental Management, Raleigh, NC. Report No. 90-01.

${ }^{74}$ NCDEM. 1991. Coastal Marinas: Field Survey of Contaminants and Literature Review. North Carolina Division of Environmental Management, Raleigh, NC. Report No. 91-03.

${ }^{75}$ The Netherlands Ministry of Housing, Spatial Planning and the Environment. Environmental Inspectorate. 2004. http://www2.vrom.nl/pagina.html?id=8701 Accessed October 31, 2005.

${ }^{76}$ College Toelating Bestrijdingsmiddelen. Pesticides Database Online. 2004. http://www.ctbwageningen.nl/

${ }^{77}$ Swedish Chemicals Inspectorate. For a Non-Toxic Environment. 2004.

http://www.kemi.se/templates/Page 498.aspx

Accessed October 31, 2005

${ }^{78}$ Ministry of the Environment Danish Environmental Protection Agency. Statutory Order on Biocidal Antifouling Paint. 2003. http://www.mst.dk/homepage/default.asp?Sub=http:// www.mst.dk/rules/ Accessed October 31, 2005.

${ }^{79}$ Keystones, Inc. 2001. Anti-Fouling Paint Desk Market Research Report. http://www.keystones.dk/

${ }^{80}$ Johnson, L and J. Gonzalez. 2004. Staying Afloat with Nontoxic Antifouling Strategies for Boats. California Sea Grant College Program Technical Report No. T-054. 21p.

${ }^{81}$ Swain, G. 2000. University research on antifouling strategies and environmental considerations.

Presentation to Alternative Antifouling Strategies Conference, September 21-22, 2000. San Diego, CA.
${ }^{82}$ Swain, G. C. Kavanagh, B. Kovach, R. Quinn. 2001 The antifouling performance of non-toxic silicone fouling release coatings. In: Proceedings of Symposium on Prevention of Pollution from Ships and Shipyards. April 4-5, 2001. Miami, FL.

${ }^{83}$ Swain, G. C. Kavanagh, B. Kovach, R. Quinn. 2001 The antifouling performance of non-toxic silicone fouling release coatings. In: Proceedings of Symposium on Prevention of Pollution from Ships and Shipyards. April 4-5, 2001. Miami, FL.

${ }^{84}$ Keijman , J.M. The evolution of siloxane epoxy coatings in the in the protective coatings industry. Technical Director: Ameron International. http://www.ameroncoatings.com/techcenter/docs/Evo lutionofsiloxaneepoxycoatings.pdf Accessed November 8, 2005.

${ }^{85}$ Haslbeck, E. 2005. Naval Surface Warfare Center, Carderock Division, personal communication.

${ }^{86}$ Easy On Bottom Wax. 2005.Boat Care Products. http://alexmilne.com/amaf.htm Accessed November 8, 2005.

${ }^{87}$ Kittar, R. 2004. Aurora Marine Industries Inc., personal communication.

${ }^{88}$ Sifton, B. 2004. $21^{\text {st }}$ Century Coatings, personal communication.

${ }^{89} 21^{\text {st }}$ Century Coatings. 2005. No-Tox Fouling

Release Control. http://www.21st-centurycoatings.com/ Accessed November 8, 2005.

${ }^{90}$ Campbell, C. 2005. Clean Seas Company. Personal communication.

${ }^{91}$ Clare, A.S. 1996. Marine natural product antifoulants: status and potential. Biofouling 9:211229.

${ }^{92}$ Rittschof, D. 1999. Fouling and natural products as antifoulants. Pp. 245-257. In, M. Fingerman et al.(eds), Recent Advances in Marine Biotechnology. Vol. 3. Biofilms, Bioadhesion, Corrosion, and Biofouling. Science Publishers Inc., Enfield, USA

${ }^{93}$ Wahl, M., P.R. Jensen, W. Fenical. 1994. Chemical and control of bacterial epibosis on ascidians. Marine Ecology Progress Series 110:45-57.

${ }^{94}$ Willemsen, P.R., and G.M. Ferrari. 1993. The use of antifouling compounds from sponges in antifouling paints. Surface Coatings International 10:423-427.

${ }^{95}$ Armstrong, E., K.G. Boyd, A. Pisacane, C.J. Peppiatt, J.G. Burgess. 2000. Marine microbial natural products in antifouling coatings. Biofouling 16:215-224.

${ }^{96}$ Peppiatt, C.J., A. Armstrong, A. Pisacane, J.G. Burgess. 2000. Antibacterial activity of resin based coatings containing marine microbial extracts. Biofouling 16:225-234. 
${ }^{97}$ Global Source Advantage.

http://www.naturesrepellent.com/ Accessed

November 8, 2005.

${ }^{98}$ DeVaney, J. 2004. Global Source Advantage, personal communication.

${ }^{99}$ Haslbeck, E. 2005. Naval Surface Warfare Center, Carderock Division, personal communication.

${ }^{100}$ E Paint. 2005. http://www.epaint.net/faq.shtm Accessed November 8, 2005.

${ }^{101}$ E Paint Company. 2005. EP2000 brochure. http://www.epaint.net/index.shtm

${ }^{102}$ Meyer, A.E., Baier, R.E., Forsberg, R.L. 1994.

Field trials of nontoxic fouling-release coatings.

Proceedings of $4^{\text {th }}$ International Zebra Mussel

Conference, Report No. TR-104029 published by

Electric Power Research Institute, Palo Alto, CA

273-290.

${ }^{103}$ Callow, M.E., Pitchers, R.A., and R. Santos. 1988.

Non-biocidal antifouling coatings. In:

Biodeterioration 7, (eds) D.R. Houghton, R.N. Smith, and H.O.W. Eggins. Elsevier Applied Science, Oxford, pp.43-48.

${ }^{104}$ Swain, G.W. and M.P Schultz. 1996. The testing and evaluation of non-toxic antifouling coatings.

Biofouling 10 (1-3):187-197.

${ }^{105}$ Briggs, R. 2004. Bottom Liner, personal communication.

${ }^{106}$ Bottom Liner. 2005. http://www.bottomliner.com Accessed November 8, 2005.

${ }^{107}$ Armored Hull Marine Products. 2005.

http://www.armoredhull.com/ Accessed November 8, 2005.

${ }^{108}$ Johnson, L.T. and J.A. Gonzalez. 2004. Staying Afloat with Nontoxic Antifouling Strategies for Boats. California Sea Grant College Program Report No. T-054. 21 p.

${ }^{109}$ Warburton, Ted. Brisbane Marina, Brisbane, CA. Personal communication, January 27, 2006.

${ }^{110}$ HydroHoist Boat Lifts. 2005.

http://www.boatlift.com/ Accessed November 8, 2005.

${ }^{111}$ AirBerth Boat Lifts. 2005.

http://www.airberth.com/ Accessed November 8, 2005.

${ }^{112}$ Carson, R., M. Damon, L. Johnson and J. Miller. 2002. Transitioning to Non-Metal Antifouling Paints on Marine Recreational Boats in San Diego Bay. Pursuant to Senate Bill 315 passed in 2001; submitted to California Department of Boating and Waterways in 2002.

${ }^{113}$ Johnson, L and J. Miller. 2003. Making Dollars and Sense of Nontoxic Antifouling Strategies for Boats. California Sea Grant College Program Technical Report No. T-052. 13p.
${ }^{114}$ Carson, R., M. Damon, L. Johnson and J. Miller. 2002. Transitioning to Non-Metal Antifouling Paints on Marine Recreational Boats in San Diego Bay. Pursuant to Senate Bill 315 passed in 2001; submitted to California Department of Boating and Waterways in 2002.

115 Johnson, L. and J. Miller. 2003. Making Dollars and Sense of Nontoxic Antifouling Strategies for Boats. California Sea Grant College Program Technical Report No. T-052. 13p.

${ }^{116}$ Johnson, L and J. Gonzalez. 2004. Staying Afloat with Nontoxic Antifouling Strategies for Boats.

California Sea Grant College Program Technical Report No. T-054. 21p.

117 Johnson, L and J. Gonzalez. 2004. Staying Afloat with Nontoxic Antifouling Strategies for Boats. California Sea Grant College Program Technical Report No. T-054. 21p.

118 Johnson, L and J. Miller. 2003. Making Dollars and Sense of Nontoxic Antifouling Strategies for Boats. California Sea Grant College Program Technical Report No. T-052. 13p.

${ }^{119}$ United States Senate. 2005. S. 770. National Aquatic Invasive Species Act of 2005. Sec. 305 (2) (B) (ii) (III). http://thomas.loc.gov/cgibin/query/F?c109:2:./temp/ c109kcz7JG:e91031 Accessed October 18, 2005.

${ }^{120}$ United States House of Representatives. 2005. H.R. 1591. Sec. 305 (2) (B) (ii) (III). http://thomas.loc.gov/cgibin/query/F?c109:1:/temp/ c109kcz7JG:e86012 Accessed October 18, 2005.

${ }^{121}$ Floerl, O., N. Norton, G. Inglis, B. Hayden, C. Middleton, M. Smith, N. Alcock, and I. Fitridge. 2004. An investigation of hull cleaning and associated waste treatment options for preventing the spread of non-indigenous marine species. Final Research Report for Ministry of Fisheries Project ZBS2002-04 Objectives 1 \& 2. National Institute of Water and Atmospheric Research

${ }^{122}$ U.S. Navy Uniform National Discharge Standards. Underwater Ship Husbandry Nature of Discharge Report. http://unds.bah.com/Nod/uwshphub.pdf Accessed October 27, 2005.

${ }^{123}$ Coutts, A.D.M. 2002. The development of incursion response tools-underwater vacuum and filtering system trials. Report prepared for NZ Diving and Salvage Ltd. Cawthron Report No. 755.

Cawthron Institute, Nelson.

${ }^{124}$ Hoffman, Marlan, California Marine Services and William Rocco, Aquarius Yacht Maintenance, San Diego, CA. Personal communications, December 2005.

${ }^{125}$ Roberts, William, Shelter Island Boatyard, San Diego, CA and Bruce Miller, South Bay Boatyard, 
Chula Vista, CA. Personal communications, December 2005.

${ }^{126}$ California Department of Boating and Waterways. 2002. California Boating Facilities Needs

Assessment. Volume 2: Regional Boaters and Boating Facilities.

${ }^{127}$ California Department of Boating and Waterways. 2002. California Boating Facilities Needs

Assessment. Volume 2: Regional Boaters and Boating Facilities.

${ }^{128}$ Warburton, Ted. Brisbane Marina, Brisbane, CA. Personal communication, January 27, 2006.

${ }^{129}$ Johnson, L.T. and J.A. Gonzalez. 2004. Staying Afloat with Nontoxic Antifouling Strategies for Boats. California Sea Grant College Program Report No. T-054. 21 p. Coutts, A.D.M. 2002. The development of incursion response tools-underwater vacuum and filtering system trials. Report prepared for NZ Diving and Salvage Ltd. Cawthron Report No. 755. Cawthron Institute, Nelson. 


\section{$X$. Restrictions on the Use of Marine Antifouling Paints Containing Tributyltin and Copper}

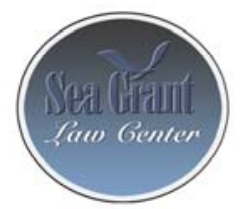

This was commissioned by the California Sea Grant Extension Program to support the Program's ongoing aquatic invasive species research, education, and outreach activities. The following information is intended as advisory research only and does not constitute legal representation of California Sea Grant or any of its constituents by the National Sea Grant Law Center. It represents our interpretation of the relevant laws.

Tributyltin (TBT) based antifouling paints have proven extremely effective at preventing the fouling of ships' hulls and consequently the transport of aquatic invasive species (AIS). The United States partially banned the use of TBT in 1988 and a global ban is forthcoming. The global ban may have serious implications in the management of AIS transport. This survey of the legal regime in the United States regarding prevention of pollution from TBT and copper antifouling paints was commissioned by California Sea Grant to support research, education, and outreach activities.

\section{Tributyltin (TBT)}

\section{A. International Ban}

In 2001, the International Maritime

Organization (IMO) adopted the International Convention on the Control of Harmful Antifouling Systems on Ships (AFS Convention). The AFS Convention bans the use of environmentally-damaging ship hull "anti-fouling systems.” Practically speaking, this means signatory nations must ban or restrict the use of organotin-based (chemical compounds containing tin and carbon used as a biocide in an antifouling paint ${ }^{1}$ ) marine paints on ships flying their flags, as well as ships using any of their ports, shipyards, or offshore facilities.

Ships greater than 400 gross tonnage, sailing internationally, must be screened before receiving a required International Antifouling System Certificate. The Certificate must be renewed when antifouling systems (like paint) are changed or replaced. Ships over 24 meters in length, but less than 400 gross tonnage must keep onboard a "Declaration on Antifouling Systems,” including proof of compliance with the Convention, such as a paint receipt or contractor invoice.

The ban on applying or reapplying organotin-based systems began January 1, 2003. By January 1, 2008, ships must either bear no organotin compounds on their hulls or surfaces, or must have covered the noncomplying organotin layer with a coating to prevent the organotins from leaching into the water. None of these rules apply to fixed platforms, floating platforms, Floating Storage Units, or Floating Production, Storage and Offshore Loading structures.

The AFS Convention is not yet in force. The Convention will enter into force twelve months after 25 nations representing 25 percent of the world's merchant shipping tonnage have ratified it. As of July 31, 2005, 11 nations have ratified the Convention, representing $8.72 \%$ of the world's fleet. ${ }^{2}$ The United States has signed the treaty, but it has not yet been sent to the Senate for ratification.

\section{B. United States Federal Law}

On the federal level, the sale and use of TBT is governed by two statutes - the Federal Insecticide, Fungicide, and Rodenticide Act (FIFRA) and the Organotin Antifouling Paint Control Act (OAPCA). FIFRA 
requires the registration of all pesticides sold or distributed in the United States. In order to register a product, the applicant must show that the product can be used without causing "unreasonable adverse effects on the environment."3

In January 1986, Environmental Protection Agency (EPA) initiated a review of TBT antifoulant registrations. ${ }^{4}$ In October 1987, EPA issued a Preliminary Determination to Cancel Certain Registrations of TBT in which the agency proposed, among other things, to cancel all registrations that exceeded a daily release rate of 4.0 micrograms and prohibit the use of TBT antifouling paints on all non-aluminum vessels under 65 feet. $^{5}$

In 1988, Congress enacted a partial ban on TBT antifouling paints, eliminating the need for EPA action. ${ }^{6}$ The OAPCA banned the application of antifouling paint containing organotin to vessels less than 25 meters in length. ${ }^{7}$ Organotin is defined as "any compound of tin used as a biocide in an antifouling paint."8 The prohibition does not prevent the application of organotin antifouling paints to the aluminum hull, outboard motor, or lower drive unit of a vessel less than 25 meters in length. ${ }^{9}$

The Act also prohibits the sale or delivery of an antifouling paint containing organotin or the application of paint to a vessel, unless the paint is certified by the Administrator of the EPA as a "qualified antifouling paint containing organotin.” A qualified paint is a paint containing organotin that is allowed to be used under the terms of a final decision of the Administrator, or certified as having a release rate of not more than 4.0 micrograms per square centimeter per day. ${ }^{10}$

The Act directed the Administrator to issue final water quality standards for organotin compounds by March 30, $1989 .{ }^{11}$ The EPA released its final ambient water quality criteria for TBT in January 2004, pursuant to Section 304(a) of the Clean Water Act (CWA). ${ }^{12}$ The criteria apply to both fresh and saltwater, and were designed for use by states and tribes in the development of their own TBT water quality standards. Though the EPA's criteria are not legally binding, National Pollution Discharge Elimination System (NPDES) permits and related environmental programs may make the criteria enforceable. EPA recommends the following criteria.

Freshwater:

For TBT, the criterion to protect freshwater aquatic life from chronic toxic effects is $0.072 \mu \mathrm{g} / \mathrm{L}$. This criterion is implemented as a fourday average, not to be exceeded more than once every three years on the average. The criterion to protect freshwater aquatic life from acute toxic effects is $0.46 \mu \mathrm{g} / \mathrm{L}$. This criterion is implemented as a onehour average, not to be exceeded more than once every three years on the average.

\section{Saltwater:}

For TBT, the criterion to protect saltwater aquatic life from chronic toxic effects is $0.0074 \mu \mathrm{g} / \mathrm{L}$. This criterion is implemented as a fourday average, not to be exceeded more than once every three years on the average. The criterion to protect saltwater aquatic life from acute toxic effects is $0.42 \mu \mathrm{g} / \mathrm{L}$. This criterion is implemented as a onehour average, not to be exceeded more than once every three years on the average. ${ }^{13}$

EPA cautions that locally important freshwater and saltwater species that are 
very sensitive to TBT levels may require lower thresholds.

The EPA is also working with the U.S. Naval Sea Systems Command (NAVSEA) to address marine antifoulant leaching. Under the Uniform National Discharge Standards for Vessels of the Armed Forces (commonly known as the Uniform National Discharge Standards Program), the Administrator of the EPA and the Secretary of Defense "have determined that it is reasonable and practicable to require use of a Marine Pollution Control Device for at least one class of vessel to mitigate adverse impacts on the marine environment ... [due to] the leaching of antifoulant materials into the surrounding seawater."14 Research is underway to develop a marine pollution control device to manage or avert these emissions into the waters of the United States.

\section{State Laws}

Not all states have adopted legislation prohibiting the use of TBT-based antifouling paints. Most of the state laws summarized below were adopted prior to the OAPCA. After 1988, state action was unnecessary to prohibit the use of TBT, which most likely accounts for the lack of TBT-specific legislation in the other states. Furthermore, because antifouling paints are generally considered pesticides subject to regulation under a state's generic pesticide laws, specific legislation banning TBT may be considered redundant in some states.

\section{Alaska}

Alaska bans the sale or use of TBT-based marine antifouling paint or coating. ${ }^{15}$ It is also illegal to sell, rent, lease, import or use "a vessel, fishing gear, or other item intended to be partially or completely submerged in the water, if the vessel, gear, or item has been painted or treated with
TBT-based marine antifouling paint or coating."16 Vessels include barges and aircraft equipped to land on water.

Slow-leaching TBT-based marine antifouling paint, TBT-based paint with "a measured release rate equal to or less than the maximum release rate established for qualified antifouling paints containing organotin by the [EPA]," ${ }^{\text {,17 }}$ can be sold in and imported into Alaska. However, these paints may only be applied to aluminum vessel hulls and lower outboard drive motors. ${ }^{18}$

\section{California}

California law lists "tributyltin, organotin, or a tri-organotin compound formulated as an antifouling paint, coating or compound and labeled for the control of fouling organisms in an aquatic environment" as a restricted pesticide. ${ }^{19}$ Except as discussed below, "antifouling paints or coatings containing tributyltin shall not be applied to any surface or object that will come into contact with the freshwater or marine environment."20

California allows the use of TBT-based antifouling paints or coatings on vessels over 82 feet ( 25 meters) in length, vessels with aluminum hulls, and outboard motors and lower drive units. ${ }^{21}$ These paints, however, "shall have an average release rate of no more than four micrograms of organotin per square centimeter per day.”22

Permits are not required for antifouling paints containing TBT. ${ }^{23}$ To buy TBT antifouling paints or coatings, however, a purchaser must show the seller a copy of the vessel registration to verify that the vessel to be painted or coated meets the requirements of California law. If the buyer has no vessel registration documents, or if the paint or coating will be used on an outboard motor or lower drive unit, the buyer must make a 
sworn statement saying that the paint or coating will only be used on an aluminum vessel hull, a vessel hull 82 feet or longer, or on an outboard motor or lower drive. ${ }^{24}$

TBT oxide pesticides, sold as additives for mixing with paints or coatings, cannot be applied "to any surface that comes into contact with the aquatic or marine environment including, but not limited to, vessels, piers and fishing equipment." 25 California also limits the average release rate for TBT antifouling paints or coatings to a maximum of "four micrograms of organotin per square centimeter per day.”26 The sale or possession of a pesticide product containing TBT, used to limit fouling in cooling water systems, is also prohibited in many California counties (Alameda, Contra Costa, Marin, Napa, San Francisco, San Mateo, Santa Clara, Solano, and Sonoma). ${ }^{27}$

\section{Connecticut}

In March 1987, Connecticut prohibited the registration or use of "any antifouling paint or other substance containing a tributyltin compound for use or application on vessels or other structures or equipment in fresh water or the marine environment."28 Seaplanes are not included in the definition of vessels. Paints with a release rate equal to or less than 4.0 micrograms per square centimeter per day may be sold and distributed to a commercial boatyard if the paint is applied only within the commercial boatyard to vessels exceeding 25 meters in length or to aluminum hulls. ${ }^{29}$ The sale, application, or possession of antifouling paints is also permitted if the paint is in a spray can of 16 ounces or less, labeled as an outboard or lower drive unit paint, and has a release rate equal to or less than 4.0 micrograms. $^{30}$

\section{Florida}

Antifouling paints containing organotin compounds with an acceptable release rate (not exceeding 4.0 micrograms per square centimeter per day at steady-state conditions $^{31}$ ) are listed as restricted-use pesticides and, therefore, may only be sold, distributed, and used in Florida by licensed dealers and applicators. ${ }^{32}$ Licensed applicators may apply TBT-based paints to vessels which exceed 25 meters in length or to vessels with aluminum hulls. Florida also exempts organotin antifouling paints in aerosol cans of 16 ounces or less for use on outboard motors or lower drive units. ${ }^{33}$

\section{Maine}

In Maine, "a person may not distribute, possess, sell, offer for sale, apply or offer for application any antifouling paint or trap dip containing a tributyltin compound." ${ }^{\text {,3 }}$ There are two exceptions. First, “a person may distribute or sell an antifouling paint containing a tributyltin compound with an acceptable release rate to the owner or agent of a commercial boatyard" and a commercial boatyard owner or agent may purchase a TBT compound as long as the compound is applied only within the commercial boatyard to vessels exceeding 25 meters in length or to vessels with aluminum hulls. ${ }^{35}$ Second, the sale, application, or possession of an antifouling paint containing a TBT compound is not prohibited if the paint "is in a spray can of 16 ounces or less, is commonly referred to as an outboard or lower drive unit paint and has an acceptable release rate." ${ }^{36}$ Acceptable release rate means "a measured release rate equal to or less than 4.0 micrograms per square centimeter per day at steady-state conditions."37 Maine also prohibits the distribution, sale, and application of any substance that contains a TBT compound in concentrated form for mixing with other paints or solvents to produce an antifouling 
paint for use on vessels, wooden lobster traps, fishing gear, floats, moorings, or piers. $^{38}$

\section{Maryland}

In Maryland "a person may not distribute, possess, sell, offer for sale, use, or offer for use any antifouling paint containing a tributyltin compound" or "any substance that contains a tributyltin compound in concentrated form and that is labeled for mixing with paint by the user to produce an antifouling paint for use on a vessel." 39 Maryland allows the distribution and sale of TBT-based antifouling paints with acceptable release rates to commercial boatyards for application within the boatyard to vessels exceeding 25 meters in length or with aluminum hulls. ${ }^{40}$ The sale of antifouling paints with TBT-compounds is also permitted if the paint has an acceptable release rate, is in a spray can of 16 ounces or less, and is commonly referred to as an outboard or lower drive unit paint. ${ }^{41}$

The Maryland antifouling paint laws have some unique provisions. First, it is important to note that Maryland deviates from the federal recommended release rate standard. Maryland defines "acceptable release rate" as "a measured release rate equal to or less than 5.0 micrograms per square centimeter per day."42 The provision, however, has no practical effect as the more stringent federal standard in the OAPCA controls.

Additionally, "out-of-state vessels that have an antifouling paint containing a tributyltin compound in excess of an acceptable release rate may travel and dock in state waters."43

\section{Massachusetts}

Massachusetts prohibits the application of antifouling products containing TBT "to the hull or bottom of any non-aluminum hulled boat, ship or vessel less than 25 meters in length." ${ }^{44}$ In addition, "no person shall disperse, dispose of or deposit paint, paint scrapings, paint chips or paint waste containing tributyltin into any lake, stream, harbor, estuary, ocean, marina, canal or other water body. Tributyltin product wastes must be disposed of in a manner as not to contaminate any lake, stream, harbor, estuary, ocean, marina, canal or area subject to the [Massachusetts] Wetlands Protection Act." 45

\section{New Jersey}

New Jersey prohibits "all marine uses of free association formulations of antifoulant paints and co-polymer formulations with release rates greater than the acceptable release rate. ${ }^{~} 46$ The acceptable release rate in New Jersey is 4.0 micrograms per square centimeter per day. ${ }^{47}$ Like most states, however, there are exceptions. Applications of a TBT antifouling paint can be made within commercial boatyards to vessels which exceed 25 meters in length or with aluminum hulls. ${ }^{48}$

\section{New York}

New York banned the sale and application of quick-release TBT antifoulant bottom paints as of January $1,1988 .{ }^{49}$ Quick release means a release rate of greater than five micrograms per square centimeter per day. New York also banned the application of bottom paints with release rates of greater than one microgram or less than five micrograms to "any non-aluminum part of any vessel less than twenty-five meters in length."50

The New York regulations state that the distribution, sale, purchase, possession, and use of TBT products labeled for aquatic antifouling uses is restricted to paints with a release rate that does not exceed four micrograms per square centimeter of application area per day in containers that do not exceed 32 fluid ounces. ${ }^{51}$ These paints 
may only be applied to aluminum hulls or other aluminum parts. ${ }^{52}$

\section{Oregon}

“A person may not sell, offer to sell or use in [Oregon] tributyltin-based marine antifouling paint or coating unless a method of using such paint or coating exists that does not result in the release of tributyltin or derivative or organotin into the waters of the state."53 Oregon permits the use of lowleaching TBT marine antifouling paints and coatings on aluminum hulls and ships greater than 25 meters in length and permits the sale of low-leaching TBT paints if sold in a spray can containing 16 ounces or less and commonly referred to as an outboard or lower drive unit paint. ${ }^{54}$ A low-leaching paint or coating "means a tributyltin-based marine antifouling paint or coating that has a steady state release rate of not more than 5.0 micrograms per square centimeter per day." 55 The Environmental Quality Commission is authorized to adopt a lower release rate by rule if necessary to protect health or the environment. ${ }^{56}$

\section{Rhode Island}

In 1988, Rhode Island enacted the Tributyltin Antifoulant Paint Control Act. The Act prohibits the distribution, possession, sale, application, or offer for sale, use or application any marine antifoulant paints containing TBT compounds. ${ }^{57}$ A person, however, may distribute or sell TBT-based paints with an acceptable release rate to a commercial boatyard for application within the yard to "vessels which exceed sixty-five feet (65') in length or which have aluminum hulls or to vessels less than sixty-five feet (65') in length if it is applied only to the outboard or lower drive unit of the vessels." ${ }^{28}$ The distribution, sale, and application of antifouling paints with acceptable release rates is permitted "if the paint is distributed or sold in a spray can in a quantity of sixteen (16) ounces avoirdupois [avoirdupois is a system of weight] or less and is commonly referred to as outboard or lower unit paint." 59 Acceptable release rate is a release rate that does not exceed 4.0 micrograms per square centimeter per day. ${ }^{60}$

\section{Virginia}

In Virginia, “a person may not distribute, possess, sell or offer for sale, apply or offer for use or application any marine antifoulant paint containing tributyltin compounds" unless the paint has an acceptable release rate and is distributed or sold to a commercial boatyard for application within the boatyard to vessels which exceed 25 meters in length or with aluminum hulls. ${ }^{61}$

The distribution and sale of TBT paints with acceptable release rates is also permitted "if the paint is distributed or sold in a spray can in a quantity of sixteen ounces avoirdupois or less and is commonly referred to as outboard or lower unit paint." 62 The acceptable release rate in Virginia is up to 4.0 micrograms per square centimeter per day at steady-state conditions. ${ }^{63}$ Virginia also excludes seaplanes from the definition of vessels. ${ }^{64}$

\section{Wisconsin}

TBT is classified as a limited use pesticide: "a pesticide which under certain conditions or usages constitutes a serious hazard to wild animals other than those it is intended to control." 65 Wisconsin allows the use of TBT compounds and organotin derivatives if usage does not involve addition to waters of the state or to structures in contact with waters of the state or if the paint does not have release rate greater than 4.0 
micrograms per day and is used on a boat at least 65 feet in length or on an aluminum boat, boat part or boat accessory. ${ }^{66}$

\section{Canada}

In Canada, antifouling coatings are regulated under the Pest Control Products Act. A pest control product is defined as "any product, device, organism, substance or thing that is manufactured, represented, sold or used as a means for directly or indirectly controlling, preventing, destroying, mitigating, attracting or repelling any pest, and includes

(a) any compound or substance that enhances or modifies or is intended to enhance or modify the physical or chemical characteristics of a control product to which it is added, and (b) any active ingredient used for the manufacture of a control product." 67

Control products, which include biocidal antifouling paints, may not be sold in or imported into Canada unless the product has been registered, conforms to prescribed standards, and is packaged and labeled as required by law.

In 1989, Canada banned the use of TBT antifouling paints on vessels less than 25 meters in length, with the exception of vessels with aluminum hulls. ${ }^{68}$ Canada, however, allowed the use of TBT paints on vessels greater than 25 meters long, but only if the release rate was 4.0 micrograms or less of TBT per square centimeter of hull surface per day. This was identical to the release rate standard established for TBT in the U.S.

As of June 2000, the Canadian Pest Management Regulatory Agency (PMRA) stopped accepting or processing applications to register new organotin antifouling paints and began a nationwide phase out of these products. ${ }^{69}$ After a special review of TBT antifouling paints, the PMRA “determined that the use of TBT antifouling paints represents an unacceptable risk to the marine environment.” Anticipating the global ban on TBT, Canada completely banned the sale and use of TBT antifouling paints in 2002. Copper-based biocidal antifouling paints are currently the only paints registered for use in Canada.

\section{Copper}

Due to environmental concerns regarding the effect of copper emissions on aquatic life, the Netherlands, Sweden, and Denmark have acted to reduce the use of copper-based antifouling paints. While these restrictions may indicate a European trend to restrict copper biocides, there is little evidence that the United States is contemplating a ban on copper biocides, at least in the near future. As discussed below, the EPA and the California Non-Point Source Interagency Coordinating Committee are currently investigating the environmental effects of copper emissions, but legislative action has yet to be taken. Of course, the EPA or states do not need to promulgate new regulations to severely restrict the use of copper antifouling paints. The National Pollutant Discharge Elimination System (NPDES) permit program, Total Maximum Daily Load (TMDL) standards, pesticides laws, and many other environmental laws, regulations, and programs contain sufficient authority for the federal government and the states to act to protect the environment. While exhaustive research of state environmental programs was not conducted, it is reasonable to assume that some states are using their NPDES programs as well as other general environmental laws and 
regulations to address copper emissions in sensitive areas.

\section{A. Federal Law}

The water quality criteria (saltwater) recommended by EPA for copper are 4.8 micrograms per liter to avoid chronic toxic effects and 3.1 micrograms per liter to avoid acute toxic effects. There are currently no prohibitions on the use of copper-based marine antifouling paints, but the EPA recently released draft updated criteria for copper which are more stringent. The draft updated criteria for copper are:

Freshwater

The procedures described in the Guidelines for Deriving Numerical National Water Quality Criteria for the Protection of Aquatic Organisms and Their Uses indicate that, except where a locally important species is very sensitive, freshwater aquatic organisms and their uses should not be affected unacceptably if the 4-day average concentration of dissolved copper does not exceed the Bureau of Land Management (BLM)derived site-water LC50 (i.e., Final Acute Value (FAV)) divided by the final acute-chronic ratio more than once every 3 years on the average (i.e., the CCC); and if the 24-hour average dissolved copper concentration does not exceed the BLM-derived site-LC50 (or FAV) divided by two, more than once every 3 years on the average (i.e., the $\mathrm{CMC})$.

\section{Saltwater}

The procedures described in the Guidelines for Deriving Numerical National Water Quality Criteria for the Protection of Aquatic Organisms and Their Uses indicate that, except where a locally important species is very sensitive, saltwater aquatic organisms and their uses should not be affected unacceptably if the 4-day average concentration of dissolved copper does not exceed $1.9 \mu \mathrm{g} / \mathrm{L}$ more than once every 3 years on the average (i.e., the CCC); and if the 24-hour average dissolved copper concentration does not exceed 3.1 $\mu \mathrm{g} / \mathrm{L}$ more than once every 3 years on the average (i.e., the CMC). ${ }^{70}$

\section{B. State Laws}

\section{California}

California currently only prohibits the possession or use of a "pesticide product containing copper sulfate for the control, in sewers and drains, of tree or other plant roots, or fungal slime in the counties of Alameda, Contra Costa, Marin, Napa, San Francisco, San Mateo, Santa Clara, Solano, and Sonoma." ${ }^{71}$ However, the California Non-point Source Interagency Coordinating Committee's Marina and Recreational Boating Workgroup has formed a Copper Antifouling Paint Sub-Workgroup "to assess the degree and geographical distribution of copper pollution caused by copper antifouling paint pesticides in California's aquatic environments."72

\section{Washington}

Washington State places limits on copper discharge from shipyard dry docks on Puget Sound. This is accomplished through NPDES permits tailored to the conditions and facilities in individual shipyards. ${ }^{73}$

\section{Foreign Countries}

\section{The Netherlands}

Following an environmental risk assessement, the Netherlands banned the use of copper-containing antifoulant paints for 
use on personal watercraft in 1999. The Netherlands also banned the cleaning or scrubbing of copper-bearing antifouling coatings. However, a Netherlands court decision in early 2005 questioned whether the risk assessment was complete. The court lifted the ban on copper paint until a new assessment, which is presently being conducted, is completed. According to an official with the Netherlands Board for the Authorization of Pesticides, (College Voor de Toelating van Bestrijdingsmiddelen or CTB) there are currently no restrictions on the use of copper-containing antifouling paints. ${ }^{74}$ The CTB regulates antifouling paints as pesticides, under authority of the 1962 Pesticides Act. As a member of the European Union (EU), the Netherlands is obliged to follow the EU's Biocidal Products Directive, ${ }^{75}$ which seeks to regulate and register all chemical biocides throughout the EU. Many different types of biocide products, including pesticides, biocides, and antifoulants, are under review through this program. Under the Directive, antifoulants produced before May 2000 may still be used, under a 10 year review program. Antifoulants produced after May 2000 require full EU evaluation and approval before sale.

\section{Denmark}

On September 29, 2003, new regulations went into effect in Denmark stipulating that the use of antifouling paints on pleasure boats "may maximally release $200 \mu \mathrm{g}$ $\mathrm{Cu} / \mathrm{cm}^{2}$ after the first 14 days and maximally $350 \mu \mathrm{g} \mathrm{Cu} / \mathrm{cm}^{2}$ after the first 30 days.”76 New pleasure boats for exports and ships undertaking long journeys are exempt from the new copper emissions standards.

\footnotetext{
${ }^{1}$ Id. $\S 2402(4)$.

2 IMO, Summary of Status of Conventions. http://www.imo.org/Conventions/mainframe.asp?topi c_id=247.
}

37 UNITED STATES CODE $§ 136 a(a)$ (2005).

451 FEDERAL REGISTER 778 (Jan. 8, 1986).

${ }^{5} 52$ FEDERAL REgISTER 37,518 (Oct. 7, 1987). For a good summary of the EPA's special review, see Atochem North America, Inc. v. U.S. EPA, 759 F. Supp. 861 (D.D.C. 1991).

${ }^{6}$ The EPA negotiated with TBT-bearing coating vendors for the voluntarily cancellation of their registrations under FIFRA. The last registered TBT coating vendor, New Nautical, requested and has been approved for voluntary cancellation. This manufacturer can sell its remaining TBT stocks to vendors until December 31, 2005.

733 UNiTED STATES CODE $§$ 2403(a) (2005).

${ }^{8}$ Id. $\S 2402(4)$.

${ }^{9}$ Id. $\$ 2403(\mathrm{~b})$.

${ }^{10}$ Id. $\S 2402(6)$.

${ }^{11}$ Id. $\S 2408$.

${ }^{12}$ Notice of Availability of Final Aquatic Life Criteria Document for Tributyltin (TBT), 69 FEDERAL REGISTER 342-343 (Jan. 5, 2004).

${ }^{13}$ EPA, Ambient Aquatic Life Water Quality Criteria for Tributyltin (TBT) - Final, iv (December 2003). http:/www.epa.gov/waterscience/criteria/tributyltin.

${ }^{14} 40$ CODE OF FEDERAL REGULATIONS $\S 1700.4(\mathrm{u})$ (2005).

${ }^{15}$ Alaska STAtuTes $§ 46.03 .715(a)$ (2005).

${ }^{16}$ Id.

${ }^{17}$ Id. $\S 46.03 .715(\mathrm{e})$.

${ }^{18}$ Id. $\S$ 46.03.715(c).

${ }^{19}$ CALIFORNia CODE OF REgulations, title 3, § 6400(e) (Barclay 2005).

${ }^{20}$ Id. § 6488(b).

${ }^{21}$ Id. $\S 6488(\mathrm{a})$.

${ }^{22}$ Id. $\$ 6900$.

${ }^{23}$ Id. $\S 6414(\mathrm{c})$.

${ }^{24}$ Id $\S 6488(\mathrm{c})$.

${ }^{25}$ Id. $\S 6489$.

${ }^{26}$ Id. $\S 6900$.

${ }^{27}$ Id. $§ 6910$.

${ }^{28}$ ConneCticut Agencies Regulations $\S 22 \mathrm{a}-66-$ 2(c)(4) (2005).

${ }^{29}$ Id.

${ }^{30} \mathrm{Id}$. at $\S 22 \mathrm{a}-66-2(\mathrm{c})(4)(\mathrm{D})$.

${ }^{31}$ FLORIDA STATUTES ANNOTATED $§ ~ 487.021(1)$ (2005).

${ }^{32}$ Florida Statutes AnNOtATEd $§ 487.171(3)$ (2005).

${ }^{33}$ Florida Administrative Code Annotated $\S$ 5E-2.035(6) (2005).

${ }^{34}$ Maine ReVised Statutes, title 38, § 419-A(2)(A) (2004).

${ }^{35}$ Id. § 419-A(3)(A).

${ }^{36}$ Id. § 419-A(3)(B).

${ }^{37}$ Id. § 419-A(1)(A-1). 
${ }^{38} I d . \S$ 419-A(2)(B).

${ }^{39}$ Maryland Agriculture Code AnNotated § 5902(a) (2004).

${ }^{40} \mathrm{Id}$. § 5-902(b).

${ }^{41} I d . \S 5-902(\mathrm{c})$.

${ }^{42}$ Id. § 5-901(b).

${ }^{43} I d . \S 5$ 5-903.

${ }^{44}$ Code of MAssachusetts Regulations, title 333, § 13.08(2)(a) (2005).

${ }^{45}$ Id. $\S 13.08(2)(\mathrm{b})$.

${ }^{46}$ New Jersey Administrative Code, title 7, § 7:30-2.9(b) (2005).

${ }^{47} I d . \S 7: 30-1.2$.

${ }^{48}$ Id. § 7:30-10.2(0).

${ }^{49}$ New York Navigation LaW § 40-b(1)

(Consolidated Laws Service 2005).

${ }^{50} I d$. $\S 40-\mathrm{b}(2)$.

${ }^{51}$ New York Codes, Rules and Regulations, title 6, § 326.2(b)(9) (2005).

${ }^{52}$ Id. § 326.2(b)(9)(iii).

${ }^{53}$ OREgOn ReVISED Statutes, title 49, § 634.505 (2003).

${ }^{54} I d$. § 634.510.

${ }^{55} I d . \S 634.500(1)$.

${ }^{56} \mathrm{Id}$.

${ }^{57}$ RHODE IsLAND GENERAL LAws § 23-25.3-2(a) (2005).

${ }^{58}$ Id. § 23-25.3-2(b).

${ }^{59} \mathrm{Id} . \S$ 23-25.3-2(c).

${ }^{60}$ Id. § 23-25.3-1(1).

${ }^{61}$ VIRGinia CODE ANNOTATED, title 3.1, §3.1-249.60 (2005).

${ }^{62}$ Id. § 3.1-249.60(C).

${ }^{63}$ Id. § 3.1-249.59.

${ }^{64} \mathrm{Id}$.

${ }^{65}$ Wisconsin AdMinistRATIVE Code $§$ 80.01(4) (2005).

${ }^{66}$ Id. 80.03(13).

${ }^{67}$ REVISED STATUTES OF CANADA, chapter P-9, § 2 (1985).

${ }^{68}$ Pest Management Regulatory Agency, Special Review Announcement SRA 2000-01 Special Review of Organotin Antifouling Paints for Ship Hulls (May 9, 2000), available at www.pmraarla.gc.ca/english/pdf/sra/sra2000-01-e.pdf. ${ }^{69}$ Id.

${ }^{70}$ EPA, 2003 Draft Update of Ambient Water Quality Criteria for Copper (Nov. 2003) available at http://www.epa.gov/waterscience/criteria/copper/pdf/ master.pdf.

${ }^{71}$ California Code of Regulations, title 3 , $\S$ 6920 (2005).

${ }^{72}$ Copper Antifouling Paint Sub-Workgroup website. http://www.cdpr.ca.gov/docs/sw/caps.htm.
${ }^{73}$ Telephone interview with Steve Eberl, Water Quality Division, Washington State Department of Ecology (Oct. 8, 2004). See also NPDES and State Waste Discharge Permits Northwest Region. http://www.ecy.wa.gov/programs/wq/permits/northw est_permits.html.

${ }^{74}$ E-mail from Jan Willem Andriessen, Biocides Assessor, Netherlands Board for the Authorization of Pesticides, to Jason Savarese, Research Counsel, National Sea Grant Law Center (Aug. 30, 2005). ${ }^{75}$ Council Directive 98/8/EC 1998 O.J. (L 123) 41 http://europa.eu.int/eurlex/pri/en/oj/dat/1998/__123/__12319980424en00010 063.pdf.

${ }^{76}$ Danish Environment Newsletter (Oct. 2003). http://www.mex.dk/uk/vis_nyhed_uk.asp?id=5974\&n yhedsbrev_id=847. 


\section{The Existing U.S. Legal Regime to Prevent the Hull Transport of Aquatic Invasive Species}

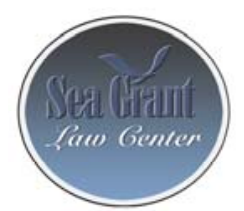

This was commissioned by the California Sea Grant Extension Program to support the Program's ongoing aquatic invasive species research, education, and outreach activities. The following information is intended as advisory research only and does not constitute legal representation of California Sea Grant or any of its constituents by the National Sea Grant Law Center. It represents our interpretation of the relevant laws.

\section{Introduction}

The predominant vector for the human transport of non-indigenous species in marine environments has been shipping. While ballast water receives the most attention, hull fouling is also a significant vector. "Hull fouling may be the most underestimated pathway for non-native introductions." "For example, 90 percent of the 343 marine alien species in Hawaii are thought to have arrived through hull fouling. ${ }^{2}$ The results of a study published in 2003 revealed that 36 percent of the nonnative coastal marine species established in continental North America could be attributed to hull fouling alone. ${ }^{3}$ Ballast water, by itself, only accounted for 20 percent. $^{4}$

Fouling refers to the process by which sessile plants and invertebrates settle on submerged artificial surfaces like boat hulls, floating docks, underwater cables, and oil platforms. To combat vessel fouling, which reduces vessel speed, increases fuel consumption, and decreases maneuverability, antifouling paints were developed. Antifouling paints contain biocidal agents to prevent larvae from settling on the boat hulls. The use of these paints has significantly reduced the risk of introductions via fouling organisms. In the 1980s, tributyl tin (TBT)-based antifouling paints became widely used. TBT is an endocrine-disrupting chemical that has been linked to masculinization of certain female gastropods and deformities in oyster shells and certain snail species. ${ }^{5}$ Environmental concerns led to a U.S. ban of TBT in 1988 and a global phase-out of antifouling systems that utilize TBT and other organotins is underway. ${ }^{6}$ Although it provides significant benefits from water quality improvement, the TBT ban will likely increase the risk of non-indigenous species introduction via hull fouling.

The U.S. legal regime to control hull fouling and the transport of invasive species via ships' hulls is extremely sparse. Hull fouling is mentioned in the United States Coast Guard's new mandatory ballast water program and several states have adopted laws to address the problem, but there "is little focused management to control fouling organisms."7 The following is a review of the existing and pending legal regime in the United States regarding the prevention of hull transport of aquatic invasive species (AIS). This paper also contains information on hull fouling activities in Canada and Mexico, as United States AIS efforts often involve collaboration with our neighbors to the north and south. Finally, Australia and New Zealand are pioneering the management of hull fouling as an invasive species pathway. Because their policies may serve as models for future U.S. efforts, these two regimes are detailed as well.

\section{Federal Laws and Guidelines}

The Lacey Act was originally passed in the U.S. in 1900 to outlaw interstate traffic in birds and other animals illegally killed in their state of origin. The Amendments strengthen and improve the enforcement of 
federal wildlife laws and improve Federal assistance to the States and foreign governments in the enforcement of their wildlife laws. Furthermore, the Act provides an important tool in the effort to gain control of smuggling and trade in illegally taken fish and wildlife. ${ }^{8}$ With regard to AIS, the Lacey Act allows federal enforcement against illegal interstate transport of listed prohibited species, such as Chinese mitten crabs.

On Feb 3, 1999, Executive Order 13112 was signed establishing the National Invasive Species Council. The Executive Order requires that a Council of Departments dealing with invasive species be created. Each Federal agency whose actions may affect the status of invasive species shall, to the extent practicable and permitted by law,

1. identify such actions;

2. subject to the availability of appropriations, and within Administration budgetary limits, use relevant programs and authorities to: (i) prevent the introduction of invasive species; (ii) detect and respond rapidly to and control populations of such species in a costeffective and environmentally sound manner; (iii) monitor invasive species populations accurately and reliably; (iv) provide for restoration of native species and habitat conditions in ecosystems that have been invaded; (v) conduct research on invasive species and develop technologies to prevent introduction and provide for environmentally sound control of invasive species; and (vi) promote public education on invasive species and the means to address them. ${ }^{9}$

On the federal level, the United States Coast Guard is the primary agency responsible for addressing hull fouling. This authority is not derived from any specific federal statute, but rather a logical outgrowth of its existing responsibilities for ballast water management and vessel inspections. While the United States Coast Guard has always been able to address hull fouling through annual vessel inspections, the new federal mandatory ballast water program directs vessel owners to remove fouling organisms.

Masters, owners, operators, or persons-in-charge of all vessels equipped with ballast water tanks that operate in the waters of the United States must:

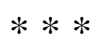

(5) Rinse anchors and anchor chains when retrieving the anchor to remove organisms and sediments at their place of origin.

(6) Remove fouling organisms from hull, piping, and tanks on a regular basis and dispose of any removed substances in accordance with local, state and federal regulations. ${ }^{10}$

Violations are punishable by a civil penalty not to exceed $\$ 27,500$, and "each day of a continuing violation constitutes a separate violation." ${ }^{11}$ Anyone who knowingly violates the ballast water regulations is guilty of a class $C$ felony, ${ }^{12}$ punishable by up to 12 years in prison. ${ }^{13}$

Hull cleaning and disposal guidelines have yet to be developed and issued by the Coast Guard. The Coast Guard has, however, developed Voluntary Guidelines on 
Recreational Activities to Control the Spread of Zebra Mussels and Other Aquatic Nuisance Species, which it promotes through boater safety courses and AIS education campaigns. ${ }^{14}$ The guidelines encourage boaters to inspect their boats, trailers, and other equipment such as anchors and remove any visible plants, animals, or mud. Boaters should also wash and dry boats and trailers once they have returned home to kill species that were not visible at the boat launch. Before transporting a boat to other waters, boat owners should

(1) Rinse [their] boat and boating equipment with hot (greater than $40^{\circ} \mathrm{C}$ or $104^{\circ} \mathrm{F}$ ) tap water;

(2) Spray [their] boat and trailer with high-pressure water; [or] Dry [their] boat and equipment for at least 5 days.

Similar suggestions are offered for seaplanes and personal watercraft.

\section{State Programs}

All states have programs to address the introduction of non-indigenous species. In most states, it is illegal to release non-native plants and animals into the natural environment. Very few states, however, have laws that specifically address hull fouling. It is important to note that many states without hull fouling management programs address hull fouling through boater awareness and educational campaigns that are not mandated by statute. This section discusses only those state programs in which there is a legal regime for hull fouling, as opposed to a generic management scheme for AIS.

\section{California}

The California Ballast Water Management and Control Program was established in
January 2000. All vessels calling on ports in California after operating outside the U.S. Exclusive Economic Zone are required to manage their ballast water and report those management activities to the California State Lands Commission (CSLC). The CSLC considers hull fouling to be of equal importance to ballast water. ${ }^{15}$ The California ballast water management program has adopted the federal guidelines and therefore contains provisions to address fouling.

The master, owner, operator, or person in charge of a vessel carrying, or capable of carrying, ballast water, that operates in the waters of the state shall do all of the following to minimize the uptake and the release of non-indigenous species:

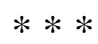

(e) Rinse anchors and anchor chains when retrieving the anchor to remove organisms and sediments at their place of origin.

(f) Remove fouling organisms from hull, piping, and tanks on a regular basis, and dispose of any removed substances in accordance with local, state, and federal law. ${ }^{16}$

\section{Hawaii}

Hawaii has a statewide Ballast Water and Hull Fouling Prevention Program. The state Legislature designated the Hawaii Department of Land and Natural Resources (DLNR) as "the lead state agency for preventing the introduction and carrying out 
the destruction of alien aquatic organisms through the regulation of ballast water discharges and hull fouling organisms." ${ }^{, 17}$ The DLNR is authorized to establish an interagency team and adopt administrative rules. Hawaii is developing its program in two stages. Phase I focuses on ballast water management and Phase II on hull fouling. Proposed rules have been drafted for ballast water, but Phase II has yet to be developed. Paul Murakawa, program coordinator, projects a target date of 2007/2008 for a completed hull fouling prevention plan, but much depends on research and funding. ${ }^{18}$ "Without dedicated funds it is unknown when, or if, regulations or administrative rules will be developed for the hull-fouling portion of the prevention program."19 The Hawaii Alien Aquatic Organism Task Force (AAOTF) is currently working with a group of stakeholders to identify criteria that will support a risk-assessment strategy for hull fouling. ${ }^{20}$

\section{Maryland}

In July 2002, Maryland implemented its ballast water management program. The Department of the Environment is the responsible agency. Maryland's program is almost identical to the U.S. Coast Guard's program. Maryland incorporated by reference the federal guidelines for ballast water management and control, ${ }^{21}$ which, as mentioned above, require vessels equipped with ballast water tanks to rinse anchors and anchor chains, and remove fouling organisms from hulls, pipes and tanks.

\section{Minnesota}

In Minnesota, “a person may not place or attempt to place into waters of the state a watercraft, a trailer, or plant-harvesting equipment that has aquatic macrophytes, zebra mussels, or prohibited invasive species attached." ${ }^{22}$ While the law does not specifically mention hull fouling and is primarily concerned with the removal of aquatic plants, a boat owner would be unable to place his/her boat in the water if harmful fouling organisms are attached to the vessel. There are a few exceptions:

Unless otherwise prohibited by law, a person may place into the waters of the state a watercraft or trailer with aquatic macrophytes:

(1) that are duckweeds in the family Lemnaceae; (2) for purposes of shooting or observation blinds in amounts sufficient for that purpose, if the aquatic macrophytes are emergent and cut above the waterline; (3) that are wild rice harvested under section 84.091; or (4) in the form of fragments of emergent aquatic macrophytes incidentally transported in or on watercraft or decoys used for waterfowl hunting during the waterfowl season. ${ }^{23}$

Minnesota conservation officers may order:

(1) the removal of aquatic macrophytes or prohibited exotic species from a trailer or watercraft before it is 
placed into waters of the

state;

(2) confinement of the watercraft at a mooring, dock, or other location until the watercraft is removed from the water; and (3) removal of a watercraft from waters of the state to remove prohibited exotic species if the water has not been designated by the commissioner as being infested with that species. ${ }^{24}$

To reduce the spread of exotic species via watercraft, the Minnesota Department of Natural Resources (MDNR) has established a Watercraft Inspection Program. In 2004, MDNR inspected 50,000 watercraft. ${ }^{25}$ Watercraft inspectors, the majority of whom are college interns, conduct inspections at public water access sites on lakes and rivers that are infested with harmful exotic species from late April to early October. In addition to inspecting watercraft, inspectors inform boaters of the state laws and proper removal methods.

\section{Oregon}

In 2001, House Bill 2181 established the Invasive Species Council to encourage reporting of invasive species and to promote educational and outreach activities.

(2) The Invasive Species Council shall:

(a) Create and maintain appropriate Internet sites, toll-free telephone numbers or other means of communication for statewide use in reporting sightings of invasive species.

(b) Encourage the reporting of invasive species sightings by publicizing means of communication made available by the council under paragraph (a) of this subsection.

(c) Forward reports of invasive species sightings to appropriate agencies.

(d) Produce educational materials and press releases concerning invasive species.

(e) Conduct educational meetings and conferences.

(f) Develop a statewide plan for dealing with invasive species. The plan should include, but need not be limited to, a review of state authority to prevent the introduction of invasive species and to eradicate, contain or manage existing invasive species.

The council was given grant-making authority and was directed to create a plan to prevent and minimize the effects of invasive species within the state. The state also publishes quarantines on problematic species. ${ }^{26}$

\section{Washington}

Ballast water in Washington is regulated under RCW 77.120 (2000) as well as under 16 United States Code Section 4701 as implemented via 33 Code of Federal Regulations, part 151(1998).

After July 1, 2002 discharge of ballast into state waters is authorized only if there has been an open sea exchange (50 or more nautical miles offshore) or if the vessel has treated its ballast water to meet standards set by the department.

The Washington State Aquatic Nuisance Species (ANS) Management Plan's (1998) purpose is to coordinate all ANS management actions currently in progress within Washington, and to identify additional ANS management actions, 
especially those relating to ANS animals. The development of a state management plan is called for in Section 1204 of the National Invasive Species Act of 1996 (Appendix A).

The Washington ANS Management Plan is focused on the identification of feasible, cost effective management practices to be implemented in partnership with tribes, private, and public interests for the environmentally sound prevention and control of ANS. The objectives identified in the plan are structured to achieve the goal through the implementation of strategic actions and tasks designed to solve specific problems. The plan is periodically revised and adjusted based upon the practical experience gained from implementation, scientific research, and new tools as they become available. The current revision has been developed with the assistance of the Aquatic Nuisance Committee formed by the 2000 Washington Legislature for the purpose of fostering state, federal, tribal and private cooperation to prevent the introduction and spread of ANS. The coordinated efforts and cooperative funding outlined in the State ANS Management Plan can enable the prevention, eradication or control of new introductions more effectively, before they cause major environmental and economic damage. ${ }^{27}$

\section{Wisconsin}

In Wisconsin, no person may place or use a boat or boating equipment or place a boat trailer "in a navigable water if the person has reason to believe that the boat, boat trailer, or boating equipment has any aquatic plants attached" or "in the Lower St. Croix River if the person has reason to believe that the boat, boat trailer or boating equipment has zebra mussels attached." ${ }^{28}$ Law enforcement officers have the authority to order a person to: (a) Remove aquatic plants from a boat, boat trailer, or boating equipment before placing it in navigable water. (b) Remove or not place a boat, boat trailer, or boating equipment in navigable water if the law enforcement officer has reason to believe that the boat, boat trailer, or boating equipment has aquatic plants attached.

(c) Remove zebra mussels from a boat, boat trailer or boating equipment before placing it in the Lower St. Croix River.

(d) Remove or not place a boat, boat trailer or boating equipment in a navigable water if the law enforcement officer has reason to believe that the boat, boat trailer or boating equipment has zebra mussels attached. ${ }^{29}$

As in Minnesota, this law is primarily intended to encourage the removal of aquatic plants. Wisconsin's law is narrower, however, in that boat owners are prohibited only from launching their boats in one river if zebra mussels are attached. In Minnesota, launching in any state waters with zebra mussels or other prohibited species is illegal.

\section{Vermont}

In Vermont it is illegal to transport zebra mussels, Eurasian watermilfoil, quagga mussels (Dreissena bugensis), or water chestnuts to or from any Vermont surface water. ${ }^{30}$ The Commissioner of Motor Vehicles is required to "enclose with every permanent and temporary motorboat 
registration and registration renewal certificate issued pursuant to this chapter the following statement:
'I. Transporting zebra mussels or Eurasian milfoil to or from any Vermont water surface is illegal (10 V.S.A. § 1266).

'II. If your boat or equipment is exposed to Lake Champlain or any other zebra mussel or Eurasian milfoil infested water, the following steps should be taken prior to putting your boat or equipment in another Vermont lake, pond or other water body:

'A. Inspect for and scrape off from your boat's hull or equipment or any exposed areas any visible mussels or milfoil.

'B. Carefully flush with clean water all boat hulls, outdrives, live wells, bilge, trailers, anchors, ropes, bait buckets, raw engine cabling systems and other boat parts or equipment.

'C. Dry boats, trailers and equipment thoroughly in the sun.,

\section{Virginia}

Virginia has adopted voluntary ballast water management guidelines modeled after the federal ballast water program.

Masters, owners, operators, or persons-in-charge of vessels equipped with ballast water tanks that operate in Virginia's territorial waters are requested to take the following voluntary precautions to minimize the uptake and release of harmful aquatic organisms, pathogens, and sediments:

\section{Rinse anchors and anchor chains when the anchor is retrieved to remove organisms and sediments at their place of origin. \\ 6. Remove fouling organisms from hull, piping, and tanks on a regular basis and dispose of any removed substances in accordance with applicable regulations. $^{32}$}

\section{Canada, Mexico, and Regional Efforts}

Canada and Mexico do not have legal regimes for hull fouling. Canada does have a ballast water management program. Environment Canada is the lead agency on the overall topic of invasive species. The Canadian Department of Fisheries and Oceans (DFO) shares responsibility for ballast water with Transport Canada. The DFO has adopted voluntary ballast water management guidelines and the government is drafting regulations for mandatory ballast water management that will be compatible with U.S. regulations for the Great Lakes and the St. Lawrence River systems. ${ }^{33}$ Although shipping and recreational boating have been identified as priority pathways by the Task Group on Aquatic Invasive Species under the Canadian Council of Fisheries and Aquaculture Ministers, no legislation or 
regulations appear to separately address hull fouling.

Only cursory research on Mexican law was conducted due to language barriers and time constraints, but the Law Center is confident that there are no specific legal mechanisms for the control and management of hull fouling. The foundations for a legal regime for hull fouling, however, are already in place. The Ministry of Agriculture, Livestock, Rural Development, Fisheries, and Food and the Secretariat of Environment and Natural Resources (SEMARNAP) are the primary agencies with authority for invasive species management and control. The General Law on Ecological Balance and Environmental Protection establishes the obligation of the federal government to protect aquatic ecosystems. ${ }^{34}$ Additionally, the Federal Attorney General for Environmental Protection (Profepa), a separate unit within SEMARNAP, "is specifically authorized to conduct enforcement activities and prevent the unauthorized introduction of aquatic flora and fauna species.”35

In addition to the collaborative efforts of Canada and the United States with respect to ballast water management in the Great Lakes, a tri-national effort is underway to address AIS. In 1993, Canada, Mexico, and the United States signed a side agreement to the North American Free Trade Agreement (NAFTA), the North American Agreement on Environmental Cooperation (NAAEC). The NAAEC established the Commission on Environmental Cooperation (CEC) to address regional environmental concerns and promote the effective enforcement of environmental laws. One of the CEC's major projects within its Conservation of Biodiversity Program is "Closing the Pathways of Aquatic Invasive Species across North America.” This AIS project “seeks to protect North America’s marine and aquatic ecosystems from the effects of AIS. The initiative will assist the development of a North American approach to prevention and control aimed at eliminating pathways for the introduction of invasive species among the coastal and fresh waters of Canada, Mexico and the United States." 36 One of the main objectives of the program is to "identify aquatic invasive species and pathways of invasion that concern two or more countries and steward cooperative plans of action to address those priority species and pathways.” ${ }^{37}$ The CEC is currently in the assessment phase.

\section{Foreign Legal Regimes New Zealand}

The New Zealand Ministry of Fisheries (MFish) is using a combination of regulatory and voluntary measures, and public education to curb the invasion of non-native species carried on vessels' hulls. Surveys have been conducted to document the native and introduced species present in some ports and marinas, thus giving a reference point from which to find newly arriving foreign species. About 148 organisms have invaded New Zealand waters, with $70 \%$ of those likely arriving by hull fouling. MFish monitors major ports, maintains a surveillance network for specific invasive species utilizing government inspectors and the general public, and responds to introductions of foreign species. To get help from the public, pamphlets and posters were printed and given to coastal organizations, merchants, councils, associations, researchers and agencies associated with the coast. A “Marine Invaders” telephone hotline was set up to encourage the public to notify MFish of invasive species sightings. Action plans have been formed to deal with the invaders, and seven marine species have been listed as unwanted, to aid the public in 
recognizing and reporting those foreign organisms.

In 1993, New Zealand passed the Biosecurity Act, to exclude unwanted organisms using border control, and to destroy or manage aquatic pests already in the country. The Act regulates the holding, disposal and treatment of "risk goods," which are "any organism, organic material, or other thing, or substance, that (by reason of its nature, origin, or other relevant factors) it is reasonable to suspect constitutes, harbours, or contains an organism that may . . . cause unwanted harm to natural and physical resources or human health in New Zealand; or interfere with the diagnosis, management, or treatment, in New Zealand, of pests or unwanted organisms." Hull fouling falls within the definition of "risk goods" under the Biosecurity Act.

Regulations were proposed in New Zealand that required all vessels requiring a cleaning of their fouled hulls to use facilities with containment abilities. The facilities would have also had to collect any discharges of fouling organisms and filter the discharge water to extract all organisms having a volume over 60 microns. The regulation was opened for public comment, and was subsequently deferred until better information becomes available. ${ }^{38}$ Currently, a voluntary guideline is in place, asking boaters to clean any fouling on their boats before departing from a foreign port, or have their vessel cleaned within four days of arrival. The government cautions against removing fouling by beaching the vessels or cleaning the hulls in water, unless the fouling is no more than a slime layer.

\section{Australia}

In 1998, Australia developed its Oceans Policy $^{39}$ to prevent and manage invasive marine species. Though the Policy bans tributyltin (TBT) on vessels in Australia beginning in January 2006, the Policy also cites hull fouling as a major transport for non-native species into Australian waters. A Joint Standing Committee on Conservation (SCC) and a Standing Committee on Fisheries and Aquaculture National Taskforce on the Prevention and Management of Marine Pest Incursions (SCFA) were created to study the problem of hull fouling as an invasive marine species vector, and to help develop a safe, cheap, and eco-friendly alternative to TBT.

Researchers from Australia's Commonwealth Scientific and Industrial Research Organisation (CSIRO) and the Smithsonian Environmental Research Center in Maryland developed a set of twin database systems, which allows information sharing on the identification, biology, distribution and management of invasive species.

Australia's National Introduced Marine Pests Coordinaton Group (NIMPCG) was created in 2001. ${ }^{40}$ The Group is constructing rules for the National System for the Prevention and Management of Introduced Marine Pest Incursions, which will try to prevent the introduction of new pest species to Australia, develop emergency response measures for discovered pests and manage existing, unwanted species. Victoria's state EPA requires vessels weighing less than 200 tons to discard removed organisms on land. South Australia state law forces slipway owners to use bunding (a large, impermeable "tub" that acts as a barrier to retain water that must be cleaned of organisms) and to allow no residues back into the water.

In 1997 the Australian and New Zealand Environment and Conservation Council (ANZECC) issued a Code of Practice for all 
commercial vessels in Australian waters. ${ }^{41}$ It prohibits in-water removal of fouling, with an exception for emergency conditions. Before sea chests or propellers can be cleaned, the administering authority must be given five days notice, including details of the collection process and disposal of removed material.

\section{Conclusion}

The United States is slowly beginning to adopt laws and regulations to address hull fouling. Development of a comprehensive regulatory scheme, however, is hindered by a lack of knowledge and funding. In addition, the hull fouling threat is overshadowed by ballast water. States, however, can use this to their advantage. The federal government's ballast water regulations mandate that vessel owners remove and properly dispose of fouling organisms, as do several states. Hull fouling is therefore addressed by the United States Coast Guard and its state counterparts during routine annual inspections. While some states, like Hawaii, are considering separate hull fouling programs, incorporating hull fouling management into existing ballast water laws and regulations may be the easiest and most cost-effective option currently available to states.

\footnotetext{
${ }^{1}$ State of Hawaii AIS Management Plan 3-22 (Sept. 2003).

${ }^{2}$ L.S. Godwin, Hull Fouling as a Pathway For Marine Invasions to Hawaii: Analysis of Vectors and Developing Management Strategies, Proceedings of the Third International Conference on Marine Bioinvasions, La Jolla, California, March 16-19, 2003, 45 (2003).

${ }^{3}$ Gregory Ruiz and James T. Carlton, Invasive Species: Vectors and Management Strategies 170 (2003).

${ }^{4}$ Id.

${ }^{5}$ Environmental Protection Agency, Ambient Aquatic Life Water Quality Criteria for Tributyltin (TBT) - Final 3-5 (Dec. 2003).

${ }^{6}$ The International Convention on the Control of Harmful Antifouling Systems on Ships was adopted
}

by the International Maritime Organization on October 5, 2001. When it enters into force, the convention will prohibit the use of organotins in antifouling paints.

${ }^{7}$ James Carlton, Introduced Species in U.S. Coastal Waters: Environmental Impacts and Management Priorities 17 (2001).

${ }^{8}$ The Lacey Act (18 U.S.C. 42; 16 U.S.C. 33713378)

${ }^{9}$ Executive Order 13112 of February 3, 1999. http://ceq.eh.doe.gov/nepa/regs/eos/eo13112.html Accessed February 3, 2006.

1033 Code OF FEDERAL Regulations $\S$ 151.2035(a)(5)-(6) (2005).

${ }^{11}$ Id. § 151.2007(a).

${ }^{12}$ Id. § 151.2007(b).

1318 United STATES CODE § 3581 (2005).

${ }^{14} 65$ FEDERAL REgister 82447 (Dec. 28, 2000).

${ }^{15}$ CSLC, Report on the California Ballast Water Program (Feb. 2003) available at http://www.slc.ca.gov/Division_Pages/MFD/MFD_P rograms/Ballast_Water/Documents/LegRptFull.pdf .

${ }^{16}$ CAlifornia Public Resources Code $§ 71204$ (2005).

17 HAWAil REVISED STATUTES § 187A-32(a) (2004).

${ }^{18}$ E-mail from Paul Murakawa, Aquatic Biologist, DLNR to Danny Davis, Research Associate, Sea Grant Law Center (Sept. 14, 2004).

${ }^{19}$ State of Hawaii AIS Management Plan 3-21 (Sept. 2003).

${ }^{20}$ Id. at 3-26.

${ }^{21}$ Code of Maryland Regulations, title 26 §§ 25.02.03, 25.03.03 (2005).

${ }^{22}$ MinNesota STATUTES. § 84D.10 (2004).

${ }^{23} \mathrm{Id}$.

${ }^{24} \mathrm{Id}$.

${ }^{25}$ MDNR, Harmful Exotic Species of Aquatic Plants and Wild Animals in Minnesota, Annual Report Summary for 2004, 4, available at

http://files.dnr.state.mn.us/ecological_services/invasi ves/annualreport_summary.pdf .

${ }^{26}$ Oregon House Bill 2181 (2001).

http://www.leg.state.or.us/01reg/measures/hb2100.dir /hb2181.en.html Accessed February 3, 2006.

${ }^{27}$ Washington State Aquatic invasive Species Management Plan. 2001. http://www.wdfw.wa.gov/fish/ans/2001ansplan.pdf Accessed February 3, 2006.

${ }^{28}$ WISCONSIN STATUTES $§ 30.715$ (2004).

${ }^{29}$ Id. § 30.715(3).

${ }^{30}$ Vermont Statutes AnNotated, title 10, § 1266 (2004).

${ }^{31}$ Vermont Statutes AnNotated, title 23, § 3305 (2004). 
324 VIRGINIA AdMinistrative CODE § 20-398-30 (2005).

${ }^{33}$ Government Response to the $4^{\text {th }}$ Report of the Standing Committee on Fisheries and Oceans Aquatic Invasive Species: Uninvited Guests, available at http://www.dfo-

mpo.gc.ca/communic/reports/aquaspec-espaqua/resprep_e.htm.

${ }^{34}$ Meinhard Dolle, Legal and Policy Responses to Invasive Species, Background Paper prepared for the Commission on Environmental Cooperation 11 (March 2001).

${ }^{35} \mathrm{Id}$. at 13.

${ }^{36}$ CEC, North American Agenda for Action: 2003200544 (Dec. 2002) available at http://www.cec.org. ${ }^{37}$ Id.

${ }^{38}$ E-mail from Liz Jones, New Zealand Ministry of Fisheries to Jason Savarese, Research Counsel, National Sea Grant Law Center (Sept. 2, 2004).

${ }^{39}$ Australian National Oceans Office. Australia’s Oceans Policies.

http://www.oceans.gov.au/the_oceans_policy_overvi ew.jsp

${ }^{40}$ Australian Department of the Environment and Heritage. Introduced Marine Pests.

http://www.deh.gov.au/coasts/imps/

${ }^{41}$ Scammell, M.S. and Baker, R. 2005. Code of practice for antifouling and in-water hull cleaning and maintenance.

http://www.deh.gov.au/coasts/pollution/antifouling/c ode/pubs/code.pdf 


\section{Recommendations and Conclusions}

As noted in Section I, this report is intended to assist the following groups in cooperating to prevent and control introductions of aquatic invasive species (AIS) on hulls of boats, while protecting coastal water quality:

- policy makers;

- boat owners;

- boat maintenance, repair and coating businesses;

- port, harbor, marina and yacht club managers;

- scientists;

- government agencies; and

- environmental organizations.

They will also need to decide how to do so, while protecting coastal water quality.

This report focuses on recreational boats that are generally kept in saltwater, that are removed only for maintenance and that travel by sea. Some findings may also be suitable for commercial fishing and commercial-passenger fishing boats. Recommendations and resources for controlling invasive species on trailered boats are available from the U.S. Fish and Wildlife Service's Stop Aquatic Hitchhikers! website located at http://protectyourwaters.net/. The California State Lands Commission has developed recommendations for commercial ships. ${ }^{1}$

This section is based on our analysis of information presented in this report and of findings from a workshop we held in cooperation with California State Lands Commission in San Francisco on May 11, 2005. It also includes insights gleaned from 20 years of experience in working with the boating and fishing communities on a variety of issues.

The workshop included educational presentations and opportunities for the 66 participants to deliberate and make recommendations, which are shown in Appendix F of this report. They represented: ship and boat owners; shipping, boating and coating businesses; government, academic and environmental organizations; and policy makers. The workshop thus served as a large, advisory committee meeting. Please see the workshop Proceedings for the seven speakers' presentations and participants' recommendations. $^{2}$

Recommendations proposed here include management strategies and techniques; research and education needs; and vessel hull husbandry practices. We hope they will stimulate discussion and lead to solutions that are cost effective, feasible, and sustainable in terms of both the environment and human capacity.

\section{Regional Approach and Global Perspective for all Boats and Ships}

We strongly encourage policy makers and stakeholders to develop a coordinated approach with states and provinces on the North American Pacific coast. It should consider recreational, commercial fishing and commercial-passenger fishing boats kept in saltwater, as well as ships and trailered boats. Inter-agency communication and regional sharing of research data would improve effectiveness of management programs. Lessons learned in Hawaii, the midwestern United States, Australia and New Zealand may provide useful insights. A global perspective in which experiences are shared and compatible policies are developed would improve the effectiveness of programs to control longer-distance transportation of invasive species by all types of boats. 


\section{Choose Appropriate Strategies}

The multi-billion-dollar boating and sportfishing industries depend on their ability to provide intangible recreational values. Commercial fishing and commercial-passenger fishing industries are already challenged by declining fish stocks and increased fuel costs. To save public funds and avoid burdening boat owners with less effective practices, we recommend that managers and people in the boating and fishing communities:

- Choose effective management practices with reduced economic and environmental "side effects" and

- Focus the best management practices on situations that are more likely to achieve results.

Prevention is more ecologically and cost effective than control, mitigation or eradication. Reducing the number of organisms associated with boat hulls can help to prevent introductions. The Australian government is developing management procedures for the arrival of vessels with suspected invasive species biofouling. Costs, the heavy ship and boat

Traffic on the North American West Coast, and other aspects of feasibility must also be considered in devising strategies.

Considerable effort is being devoted to assessing the full economic impacts of invasive species. The goal is to develop effective management programs to help prevent, control, or mitigate such invasions. Previously, the focus was on identifying the most cost-effective means of treatment for of an introduction. Now the emphasis is on the benefits and costs of treatments to determine how best to manage the particular invasive species. ${ }^{3}$
Although control does not eliminate entire communities of non-indigenous species, it may be more economically feasible than eradication. Control and containment are most appropriate when the species has become established and has begun to increase its range. ${ }^{4}$ Both short- and longterm costs of management strategies should be considered in policy development.

If the population of an invasive species has completely colonized and a management technique is not yet implemented, mitigation may be viable. ${ }^{5}$

\section{Immediate Action Versus Research}

Based on material presented in this report, we will propose some actions that boat owners can take immediately. Most of them are an enhancement of actions commonly taken by recreational boat owners before a cruise or before participating in an event. Some are adapted from Australian practices.

Representatives of boat owners and boating businesses have emphasized the importance of education and outreach in encouraging boaters to improve their environmental practices. We have found in 12 years of experience that education programs are most effective when developed and delivered in collaboration with boat owner and boating industry associations. Thus, immediate, collaborative, education programs will raise boater awareness of the invasive species problem, provide management practices they can readily apply and increase adoption of the recommended practices. For example, practices to reduce risks of transporting invasive species might be incorporated into existing, “Clean Marina” programs.

However, scientific research is needed to understand the scope and nature of the 
invasive species risk posed by boats on the California coast and to develop an effective, long-term strategy to prevent and control introductions. Research needs are discussed later in this section and in Appendix F.

\section{Hazard Analysis and Critical Control Point (HACCP) Strategy}

A HACCP approach identifies "critical control points" (CCPs), at which removing fouling growth from hulls and underwater running gear will be most effective in preventing or controlling invasive species transport. Focusing efforts on these points helps to reduce costs and avoid unnecessary inconvenience. This approach begins by identifying vessels and situations that pose a higher risk of transporting and introducing hull-borne invasive species. Boat owners, marina managers, resource managers, scientists and others can help to develop this information. They can use it to decide how and when to deploy antifoulants, hull cleaning and other practices, to design research to improve practices, and to design long-term solutions. The HACCP approach has been considered in recommendations presented here. See below for research needed to identify or confirm CCPs and appropriate practices to control invasive species at each one.

\section{Invasive Species and Water Quality: Tailor Hull Maintenance to the Boat}

As noted in Section IX, antifouling paints with persistent toxicants, such as tributyl tin and cuprous oxide, pose water quality problems in many boat basins. Tributyl tin antifoulants are already widely banned. Restrictions on copper-based paints have begun in San Diego Bay, and may spread to other parts of California. The California Department of Pesticide Registration and the U.S. Environmental Protection Agency
(USEPA) are re-evaluating copper-based antifoulants and are expected to announce a decision in 2008 or 2009. They will explain their risk-assessment conclusions and outline risk-reduction measures that may be required for continued registration and use of antifoulants. ${ }^{6}$ USEPA is also considering whether to lower the level of dissolved copper allowed in boat basins. ${ }^{7}$ Thus, copper-based antifoulants may become less available in California and possibly nationwide.

Recent research (see Section IX of this report) has identified copper-tolerant, invasive, hull-fouling species. This suggests that boat basins polluted by copper may provide a competitive edge to coppertolerant species brought in on boat hulls. Programs to control hull-borne invasive species will need to take water quality issues into account.

Participants in our May 11, 2005 workshop, "Managing Hull Transport of Aquatic Invasive Species," commented that, due to their shorter and less frequent voyages, recreational boats may pose a lesser risk of transporting invasive species than ships. However, they recommended conducting surveys to confirm this hypothesis. They suggested that the operational dynamic is more important than the total area of a hull surface. They also commented that it is especially important to evaluate hulls of vessels that remain in port for long periods and then travel long distances into other regions. Participants noted that studies in Hawaii found that such trips may expose a single destination to repeated inoculations of AIS. ${ }^{8}$

Boats that do not travel long distances are less likely to encounter potentially invasive species. We have observed that many recreational boats spend most of their time 
in the home slip. Further, a study by California Department of Boating and Waterways (see Table 1 of Section IV) shows that about one-half of all boaters in California's coastal counties take no trips over 100 miles from home. Because they are large in number and spend much time in the home marina, they likely contribute the lion's share to elevated copper levels. Thus, the most reduction in pollution with a low risk of invasive species transport could be achieved if such boats used nontoxic hull coatings with companion strategies, such as slip liners or frequent, in-water hull cleaning. See below for recommendations on preparing for a trip.

Boats that travel long distances are most likely to acquire and transport invasive species. Table 1 (Section IV) also shows that from two percent to seven percent of boats in California's coastal counties make frequent trips over 100 miles from home. These boats may be better candidates for copper-based or less toxic antifoulants, as opposed to nontoxic hull coatings. Because they are relatively few in number and spend more time at sea, they would discharge relatively less toxicant to confined, marina waters.

\section{General Hull Maintenance Measures to Control Invasive Species}

The following measures are proposed to control invasive species on boats kept in saltwater and removed once every one to three years to reapply paint and inspect underwater running gear and through-hull fittings. Owners of trailered boats may visit the excellent Stop Aquatic Hitchhikers! website (see below). These recommendations are incorporated in our bilingual poster, "Stop Aquatic Invaders on Our Coast!/¡Detenga el transporte de especies invasoras acuáticas en nuestras costas!”

- If you use copper-based antifouling paint, replace it when copper is depleted.

- Nontoxic boat bottom coatings are safer for aquatic life, but frequent cleaning is needed. Please visit http://seagrant.ucdavis.edu for more information.

- Clean the hull of your boat, underwater running gear, and internal seawater systems before traveling beyond your home region, especially if you will visit major ports, international waters, islands, or events with boats from other areas.

- Clean them all again before moving to another region or returning home.

- If your boat is heavily fouled after such trips, haul it for cleaning within one week after arrival and contain the fouling growth.

- Drain livewells, bait tanks, and bilge water before traveling and before returning.

- If you trailer your boat, please follow the guidelines at the Stop Aquatic

Hitchhikers! website http://www.protectyourwaters.net In California, report AIS found on your boat or in your marina to:

National ANS Hotline 1-877-STOP-ANS (1-877-786-7267)

- In Baja California, report AIS found on your boat or in your marina to: Comisión nacional para el conocimiento y uso de la biodiversidad (CONABIO) 01 (55) 5004-5000

A certificate program may be useful to assist agencies and marinas in determining which vessels have undergone appropriate hull husbandry practices with respect to water quality protection and invasive species prevention or control. Such a program should take into account local conditions 
and policies. It should be simple and easy to implement, and low cost.

\section{Consider Lessons from "Down Under"}

Dr. Oliver Floerl of the National Institute of Water and Atmospheric Research in New Zealand has found that $80 \%$ of New Zealand boats do not travel often or only travel very locally, $10 \%$ are used for wider-reaching domestic trips and another $10 \%$ are used for international travel. ${ }^{9}$ He suggests that caution should be taken before applying blanket regulations, which may unfairly target boats that do not pose a risk. His observations and recommendation are similar to those made for recreational boats in California.

Control measures developed in Australia could be evaluated and adapted for use on the North American Pacific coast. The Australian Quarantine and Inspection Service (AQIS) asks owners of vessels under 25 meters (82 feet) that are traveling internationally to be sure their boats are clean before leaving their last port: "Keep all ancillary gear and internal seawater systems clean of marine pests and growth; and clean your vessel's hull within one month before arrival; or apply antifouling paint within one year before arrival; or book your vessel in to be slipped and cleaned within one week of arrival." Note that the emphasis on antifouling paint does not consider its water quality impacts.

AQIS asks boat owners to pay special attention to the high-risk areas: "hull, keel and rudder; propellers and shafts; anchor wells (including anchor chain and rope); water intakes and outlets; tenders and outboard motors; and sea strainers and internal water systems." ${ }^{10}$ After a review of the voluntary phase, these requirements will likely become mandatory July $1,2007 .{ }^{11}$
AQIS also asks boats arriving from overseas to complete a questionnaire that will help them to determine the risk posed by the vessel and appropriate control measures. Administering such a survey for some or all California boat traffic would pose logistical challenges. Before establishing a survey system, consideration should be given to what data are critically needed, under what circumstances, and how the data will be used to reduce AIS transport by boats.

\section{Research and Education for Boats Kept in Saltwater}

Recommendations presented above should enable boat owners to take immediate action that will reduce the risks of transporting invasive species on boat bottoms. Most existing research and education on invasive species transported by vessels has focused on ships engaged in international commerce and on boats that are trailered, especially among freshwater lakes and rivers. Thus, research is needed to determine the nature and scope of risks posed by larger boats kept in saltwater that may transport invasive species on their hulls and underwater running gear.

Research is also needed to determine appropriate and cost-effective, long-term management measures and practices to prevent and control such transport.

Education programs based on this research are needed to enable boat owners, boating and hull-coating businesses, government agencies and environmental organizations to make appropriate and sustainable decisions. However, early education programs can begin to raise boater awareness of AIS and how to enhance hull husbandry practices to reduce risks of transporting them.

Additional detail is provided in Appendix F. 


\section{Ecological Risk}

Consider the following in assessing ecological risks of AIS:

- Determine the effect of increased levels of pollution found in ports, harbors and marinas, for example antifouling paint toxicants, other vessel pollution and polluted runoff, on:

0 native species and their ability to compete with introduced species;

0 non-native species introduced on boat hulls and underwater running gear.

- Determine identity and characteristics of non-native species occurring on hulls of pleasure craft, commercial fishing boats and commercial-passenger fishing boats in California and Baja California, including:

o identification;

o environmental conditions in regions of origin and destination;

o abundance on hulls;

0 abundance in recipient regions;

0 ecological (and related socioeconomic) effects in areas where they have been introduced; and

0 occurrences at major ports and at smaller harbors.

\section{Research to Refine a HACCP Approach}

Risk and critical control points (CCPs) assessments for a Hazard Analysis Critical Control Points (HACCP) system should consider at least the following questions and circumstances:

- How often a boat is used or how long it has been kept at mooring since last use;

- Vessel type, speed and typical lifespan;

- Where it is kept:

o marina in a major, shipping port,

0 marina in a smaller harbor without ship traffic,
0 antifouling water quality regulations in harbor where it is kept, o geographic region and climate;

- Types of uses, locations, route, distance traveled:

0 participation in events that attract many boats from different regions,

o cruising to distant locations,

o participation in local events with local boats,

0 cruising to locations in the region,

o travel among smaller harbors,

o travel between a major port and a smaller harbor;

- Season of the year;

- Hull husbandry practices;

- Age and type of bottom coating;

- Companion, antifouling strategies used, for example hull-cleaning frequency, slip liner, hoist;

- Level of risk associated with each CCP; and

- Management practices for each CCP.

A management system for implementing a

HACCP approach should consider at least:

- Lead organization and partners;

- Geographic scope and collaboration with other regions;

- Roles of research, education and regulation;

- Roles of community groups and government;

- Monitoring the implementation and effectiveness of practices; and

- How responsibility and costs for implementing the HACCP system are distributed among boat owners, boating and hull-coating businesses, government and taxpayers.

\section{Research on Socio-Economic Factors}

Research is needed to determine costs and burdens and how they should be distributed 
for reducing hull-borne invasive species transport by boats. Consider the following:

- Improve understanding of social and economic risks posed by invasive species transported on boat hulls.

- Determine social and economic benefits to be derived from controlling and preventing transport of invasive species on boat hulls. Compare different stages of abatement in terms of differences in costs and benefits of prevention versus control, mitigation and early response.

- Determine social, economic and environmental values of marine resources and how they may affect public and commercial response to risks posed by invasive species carried on boat hulls.

- Determine costs to implement proposed management systems and practices, such as TMDLs, permits, environmental bonds, taxes and liability rules.

- Determine costs to be carried by boat owners, marinas, government and tax payers, companies that manufacture boats and hull coatings, etc., for proposed management systems and practices, according to vessel types, uses, etc. For example:

o Eradication, control, mitigation and monitoring costs will likely be paid by government via tax funds. They may be very high and concentrated.

o Prevention costs will likely fall more heavily on boat owners and boating businesses. They may be lower overall and more widely distributed.

0 Incentives may be effective in encouraging boat owners and boating business to participate in prevention.

- Determine costs of fouling control strategies with respect to:

0 anticipated uses;

0 trip lengths and frequencies for different types of boats; o typical cruising speeds for different types of boats;

o how long boat owners typically keep a given type of boat;

o typical useful life for a given type of boat; and

0 regulatory programs in harbors where boats are kept or that they may visit.

- Determine expected effects of proposed management systems and practices on boat owner participation in boating and on boating business operations.

- Determine ways to adjust management systems, policies, and management practices to achieve effective control at a lower cost to boat owners, boating business, government and taxpayers.

\section{Research to Develop Cost and Environmentally Effective Management Systems}

Research is needed to develop cost and environmentally effective management systems. Consider the following:

- Evaluate systems used in other countries and other parts of the United States to control transport of invasive species on boat hulls.

- Determine how best to adapt them to boats kept in saltwater and traveling to locations in California and Baja California.

- Involve the boating community in research to develop effective systems that are easy for them to adopt.

- Determine how to monitor vessels at risk in a way that controls costs and reduces time/inconvenience for government, boat owners, and boating and fishing businesses.

- Determine whether and how to develop a certification system for boat owners and boating businesses using best management practices. 
- Determine how to develop a North American West Coast regional approach that considers:

0 traffic patterns for recreational and fishing boats;

0 variations in climate, culture and legal/regulatory systems among states, provinces and nations;

0 risks posed by existing invasive species and by those that may arrive in the future;

o opportunities for early detection;

o cost and environmentally effective, regional control measures and practices;

o opportunities for agencies to share data, experiences, and resources;

0 boating and fishing community insights and resources;

0 existing hull-husbandry practices in local areas, as well as wider regions;

o opportunities to control via harvest for sale or personal consumption; and

0 a stepwise approach, for example education, warning, and regulation.

\section{Hull Husbandry Research}

Research on hull husbandry practices is needed to improve invasive species

management, while protecting water quality. Consider the following:

- Determine existing hull-husbandry practices with respect to local climate, fouling communities and infrastructure.

- Determine how to adapt them for controlling invasive species transport on boat hulls and underwater running gear.

- Determine strategies that combine boat bottom coatings and companion practices, such as in-water hull cleaning, slip liners, and hoists, to:

o prevent water penetration;

0 control invasive species and other fouling growth; and
0 protect coastal water quality by meeting federal and state standards.

- Test the effectiveness of these strategies in regions with different climates, water nutrient levels, and fouling communities, and on different types of boats with different operational profiles.

- Evaluate new products and practices before recommending them to boat owners and boating businesses for:

o regulatory status;

o effect on water quality;

0 effectiveness in controlling fouling and whether they need to be combined with another product or practice;

o costs to acquire, apply and maintain;

o durability/life span; and

o effect on vessel performance, such as racing and cruising speeds and fuel consumption.

- Determine costs of fouling control strategies with respect to:

0 anticipated uses;

0 trip lengths and frequencies for different types of boats;

o how long boat owners typically keep a given type of boat;

0 typical useful life for a given type of boat; and

0 regulatory programs in harbors where boats are kept or that they may visit.

- Determine the relationship between efforts to protect water quality from impacts of copper antifoulants and efforts to control invasive species among hull-fouling growth.

- Determine management practices of high-risk boats.

- Develop hull-husbandry, bestmanagement practices based on research results and incorporate them in education and outreach programs.

- Encourage competing technologies in hull husbandry. 


\section{Education and Outreach}

We strongly recommend educating boat owners and boating businesses about problems posed by introducing invasive species and simple, cost-effective practices for controlling them. Reasons include:

- At our May 11, 2005 workshop, "Managing Hull Transport of Aquatic Invasive Species," boating community representatives strongly recommended using education and outreach to encourage boat owners and boating businesses to control invasive species carried on boat hulls and underwater running gear.

- The national, Clean Marina movement has demonstrated success using education to increase the awareness of marina managers and boat owners about water quality problems and to increase their willingness to help prevent pollution.

- A survey conducted in the Great Lakes region of the United States found that, when boaters were told about the effects of specific invasive species, they commented that they wanted to keep the species out of "my lake" and that "it is my personal responsibility." 12

- During our 12 years of experience conducting research and education to assist the boating community in pollution prevention, we have observed that clean water and abundant marine life are significant incentives that attract people to participate in boating and encourage them to prevent pollution. Further, we have observed that peer pressure and marketing advantages are significant incentives attracting marina managers to participate in Clean Marina programs.

- We have observed that boater and boating business organizations, such as BoatUS Foundation, the Association of
Marina Industries and Clean Marinas California, are successful in educating and encouraging boat owners and marina managers to prevent pollution. Associations of sportfishing, commercial fishing and commercial-passenger fishing boat owners also provide educational assistance to their members.

An education program for policy makers may also be beneficial. Policy makers should understand the challenges associated with fouling control and what will be required of the boating industry before mandating control methods.

Criteria and means for education and outreach programs to prevent hull transport of invasive species may include the following:

- Base education on scientific research.

- Increase communication among scientists, managers, policy makers, and members of the boating and fishing communities.

- Involve boat owner, boating and fishing business organizations in developing and conducting research and outreach.

- Utilize organizations with a successful record of environmental education for boat owners and boating business, for example Clean Marina programs, BoatUS Foundation, U.S. Coast Guard Sea Partners program, Sea Grant Extension programs, and U.S. Fish and Wildlife Service's Stop Aquatic Hitchhikers! Program.

- Extend information via boating and fishing organizations; Internet; supply and service businesses patronized frequently by boat owners, such as marinas, supply stores, boat brokers; and boating and fishing magazines, newspapers and radio or television programs. 
- Develop cross-border partnerships to ensure that boat owners are educated beyond their home harbors.

- Educate on specific invasive species that may be carried on boats, the problems they create for native species and for people, and means for controlling them;

- Educate boat owners to identify and report aquatic invasive species.

- Clearly explain the importance of monitoring and prevention, especially for high-risk species. If it is too late for prevention, clearly explain the importance of eradication, control or mitigation.

- Clearly explain how recommended practices help to control hull-borne invasive species, while protecting water quality and native marine life.

- Educate on practices adapted from existing fouling growth management practices to make it easy for boat owners and boating businesses to use them;

- Utilize a diversity of media and languages to reach all boat owners and boating businesses.

- Evaluate effectiveness of educational programs. Share findings, such as research needs and opportunities to improve management and education. Incorporate feedback in updates.

\section{Conclusions}

Risks posed by AIS can be expected to increase as international shipping commerce continues to grow. Ships are responsible for most of the long-distance transport of AIS in ballast water, on hulls and on underwater structures. However, there is increasing evidence that boats transport them along the coast within a region.

Hull husbandry practices to prevent and control invasive species transport will need to consider water quality, tolerances of invasive and native species to antifouling toxicants, changes in antifouling paint regulations, and costs of new products, practices and reporting requirements.

Although this report focuses on California and Baja California, invasive species management systems will need to be coordinated throughout the West Coast of North America if they are to succeed. Lessons learned in Australia, New Zealand, Hawaii and the Midwestern region of the United States can provide valuable insights. However, management systems and policies to support them must address the unique situation and characteristics of boats that are kept in saltwater and removed every one to three years for maintenance. Managers will need to communicate with each other and with policy makers, boat owners, boating, fishing and hull-coating businesses, and scientists and educators to develop effective and sustainable policies.

Boat owners and boating businesses can take immediate steps to prevent and control invasive species transport on hulls and underwater running gear. A first step would be to clean the hull before leaving the home harbor to travel visit a distant region, island or to an event with boats from other areas. Boats kept in major ports are at a higher risk of acquiring invasive species from international shipping. Their owners should be especially diligent in cleaning the hull before leaving for another harbor.

Boat owners, who have left their home region or visited a major port, should clean hulls before traveling to a new destination or returning home. Upon arrival from a distant region or major port, heavily fouled boats should be hauled out for hull cleaning. Removed material should be contained and disposed to prevent release to local ecosystems. These practices are 
enhancements of existing, hull-husbandry practices and thus should be reasonably easy to adopt.

Research is needed to more clearly define the types of invasive species that are likely to be transported on boat hulls and their expected ecological and socio-economic impacts on recipient regions. Research is also needed to develop appropriate management systems and to evaluate new hull-husbandry products and practices.

Education has a strong track record in encouraging boat owners and boating businesses to prevent pollution. It has also been demonstrated to be effective in encouraging boat owners to prevent transport of invasive species in the Midwestern United States. Representatives of boat owners and boating businesses have recommended education as the most effective tool for changing practices to prevent transport of invasive species by boats in California. Involving boat owner, boating and fishing business organizations, as well as organizations such as Clean Marina, BoatUS, Sea Partners and Sea Grant, in developing and conducting education and outreach are effective approaches. Education programs should be based on research, or on long-term and validated practices, in order to provide accurate information.

\section{References}

\footnotetext{
${ }^{1}$ Takata, L., M. Falkner and S. Gilmore. 2006. Commercial Vessel Fouling in California: Analysis, Evaluation, and Recommendations to Reduce Nonindigenous Species Release from the Non-Ballast Water Vector. Produced for the California State Legislature. California State Lands Commission, Marine Facilities Division, Sacramento, CA. April 2006. 83 p.

${ }^{2}$ Gonzalez, J. and L. Johnson, eds. 2005. Managing

Hull Transport of Aquatic Invasive Species.

Proceedings of May 11, 2005 Workshop in San
}

Francisco, California. California Sea Grant College Program Report T-059.

${ }^{3}$ Evans, E. A. 2003. "Economic Dimensions of Invasive Species." Choices. A publication of the American Agricultural Economics Association. http://www.choicesmagazine.org/2003-2/2003-202.pdf Accessed February 3, 2006.

${ }^{4}$ Grosholz, Edwin and Gregory Ruiz (eds). 2002. Management Plan for the European Green Crab. Submitted to the Aquatic Nuisance Species Task Force.

${ }^{5}$ Grosholz, Edwin and Gregory Ruiz (eds). 2002. Management Plan for the European Green Crab. Submitted to the Aquatic Nuisance Species Task Force.

${ }^{6}$ Singhasemanon, N. 2005. Minutes of Copper Antifouling Paint Sub-Workgroup Meeting of July 14, 2005. Minutes dated August 10, 2005. 5 p.

${ }^{7}$ United States Environmental Protection Agency. 2004. Draft Updated Water Quality Criteria for Copper Fact Sheet.

http://www.epa.gov/waterscience/criteria/copper/draf tupdatefs.htm Accessed December 28, 2005.

${ }^{8}$ Gonzalez, J. and L. Johnson, eds. 2005. Managing

Hull Transport of Aquatic Invasive Species.

Proceedings of May 11, 2005 Workshop in San

Francisco, California. California Sea Grant College Program Report T-059.

${ }^{9}$ Floerl, O. 2005. National Institute of Water and Atmospheric Research (NIWA), National Centre for Aquatic Biodiversity and Biosecurity, personal communication, September 27, 2005.

${ }^{10}$ Australian Quarantine and Inspection Service. 2005. Arriving in Australia with a clean hull: New rules for vessels entering Australia.

http://www.daff.gov.au/content/output.cfm?ObjectID $=7 F B A 840 F-4324-49 E 3-B 22 B C B 2 C 4 A 3 B 28 E 8$ Accessed November 8, 2005.

${ }^{11}$ Snell, T. 2006. Australian Quarantine and Inspection Services (AQIS), National Ballast Water Adviser, personal communication, December 20, 2006.

${ }^{12}$ Jensen, Douglas A. and Jeffrey L. Gunderson. 2004. Effective Strategies that Work to Prevent the Spread of Aquatic Invasive Species by Recreational Boaters. From the Abstract Proceedings of the $13^{\text {th }}$ International Conference on Aquatic Invasive Species, September 20 to 24, 2004. 


\section{Appendix A. Definitions}

Adventive plants

Alien species

Species

Biological invasions

Cryptogenic species

Escaped species

Established species

Exotic species

Feral species

Foreign species

Immigrant species
Non-native plants that are firmly established in the landscape. ${ }^{1}$

Species occurring in an area outside its historically known natural range as a result of intentional or accidental dispersal by human activities. ${ }^{2}$

Non-indigenous species that threaten the diversity or abundance of native species or the ecological stability of infested waters, or commercial, agricultural, aquacultural or recreational activities dependent on such waters. Aquatic nuisance species include nonindigenous species that may occur in inland, estuarine and marine waters and that presently or potentially threaten ecological processes and natural resources. In addition to adversely affecting activities dependent on waters of the United States, aquatic nuisance species adversely affect individuals, including health risks. ${ }^{3}$

Note: Aquatic Invasive Species Act of 2005 changes terminology from Aquatic Nuisance Species to Aquatic Invasive Species.

Introduction and spread of exotic organisms in regions outside their native range. ${ }^{4}$

Species not demonstrably native or introduced; term is used for species with insufficiently documented life histories to allow characterization as either native or introduced. ${ }^{5}$

Species released from aquaculture or laboratory, accidentally or intentionally. ${ }^{6}$

Species occurring as a reproducing, self-sustaining population in an open ecosystem, i.e., in waters where the organisms are able to migrate to other waters. ${ }^{7}$

Species not indigenous to a region. ${ }^{8}$

Domesticated species that has become wild. ${ }^{9}$

Any species introduced from a foreign country. ${ }^{10}$

Species that has arrived from another location, generally another country, without deliberate, human help. ${ }^{11}$ 
Incidental species

Incipient (Pioneer)

Infestation

Introduced species

Invasive species

NativeX

Naturalized species

Non-indigenous species

Non-native species

Pests
Alien species that have been introduced through human agency into a new area, but have not become established in the wild. ${ }^{12}$

Small colony of an invasive species that has spread to a new area. ${ }^{13}$

Species transported by human activities - intentionally or unintentionally - into a region in which they did not occur in historic time and in which they are now reproducing. ${ }^{14}$

(b) -colonizes a new area where it did not exist previously; -the extension of range is linked, directly or indirectly to human activity; -there is a geographic discontinuity between native area and new area (remote dispersal); -new generations of the non-native species are born in situ without human assistance, thus constituting self-sustaining populations: the species is established;

-only refers to innocuous introductions. ${ }^{15}$

Species whose introduction causes or is likely to cause economic or environmental harm or harm to human health. ${ }^{16}$

Term coined by researchers at Moss Landing Marine Laboratories to describe species that have been classified as native to California but are now found in an area where they had not previously been recorded. The nativeX designation connotes a possible range extension for these species which may or may not have been facilitated by human action. ${ }^{17}$

Intentionally or unintentionally introduced species that has adapted to and reproduces successfully in its new environment. $^{18}$

Plants and animals that are living outside their natural geographic boundaries. ${ }^{19}$

Any species that occupies an ecosystem beyond its historic range. ${ }^{20}$

Species likely to have a major impact in a new environment on economy, environment, human health or amenity. ${ }^{21}$ 
Priority species

Sea chest
Aquatic invasive species that is considered a significant threat to California's waters and for which immediate or continued management actions are recommended to minimize or eliminate its impact. ${ }^{22}$

Recesses built into a ship's hull beneath the waterline to reduce water cavitation and thus increase pumping efficiency when seawater is pumped aboard the vessel for engine cooling, ballast, and fire fighting purposes. ${ }^{23}$

Xenobiota

Organism that has been displaced from its normal habitat. ${ }^{24}$

\section{References}

${ }^{1}$ New Zealand Plant Conservation Network. Glossary of Terms. http://www.nzpcn.org.nz/glossary/index.asp. Accessed May 4, 2006.

${ }^{2}$ Department of the Environment, Sport and Territories (1996). National Strategy for the Conservation of Australia's Biological Diversity - Glossary. Canberra, Australia: Department of the Environment and Heritage.

http://www.deh.gov.au/biodiversity/publications/ strategy/gloss.html. Accessed May 4, 2006

${ }^{3}$ Nonindigenous Aquatic Nuisance Prevention and Control Act of 1990.

http://epw.senate.gov/nanpca90.pdf Accessed May 6, 2006.

${ }^{4}$ San Francisco Estuary Institute (2006).

Biological Invasions Program.

http://www.sfei.org/bioinvasions/index.html.

Accessed May 4, 2006.

${ }^{5}$ Fairey, R., Dunn, R., Roberts, C., Sigala, M., and J. Oliver. 2002. Introduced Aquatic Species in California Coastal Waters, Final Report. California Department of Fish and Game. San Jose State University Foundation/Moss Landing Marine Laboratories.

${ }^{6}$ MIT Sea Grant. Marine Bioinvasions Fact Sheets.

http://massbay.mit.edu/resources/pdf/Aquacultur eFactSheet.pdf. Accessed May 4, 2006.

${ }^{7}$ Hopkins, C.C.E. Actual and potential effects of introduced marine organisms in Norwegian waters, including Svalbard - Research report 2001-1 Directorate for Nature Management. ${ }^{8}$ U.S. Environmental Protection Agency. Terms of Environment: Glossary, Abbreviations and Acronyms.

http://www.epa.gov/OCEPAterms/eterms.html.

Accessed May 4, 2006.

${ }^{9}$ Department of the Environment, Sport and Territories (1996). National Strategy for the Conservation of Australia's Biological Diversity
- Glossary. Canberra, Australia: Department of the Environment and Heritage.

http://www.deh.gov.au/biodiversity/publications/ strategy $/ \mathrm{gloss} . \mathrm{html}$. Accessed May 4, 2006.

${ }^{10}$ U.S. Fish and Wildlife Service. Definitions: Region 3 Midwest Internet Site. http://www.fws.gov/midwest/ashland/definitions. html. Accessed May 4, 2006.

${ }^{11}$ J. Howard Frank, Thomas R. Fasulo, Donald E. Short, and Aaron S. Weed (2005). Definition: Immigrant Species. Gainsville, FL: University of Florida.

http://molecrickets.ifas.ufl.edu/mcri0064.htm. Accessed May 4, 2006

${ }^{12}$ Hopkins, C.C.E. Actual and potential effects of introduced marine organisms in Norwegian waters, including Svalbard - Research report 2001-1 Directorate for Nature Management. ${ }^{13}$ California Department of Fish and Game. 2003. California Aquatic Invasive Species Management Plan. Draft.

${ }^{14}$ A Survey of Non-Indigenous Aquatic Species in the Coastal and Estuarine Waters of California. 2002. Submitted to the California State Legislature as required by the Ballast Water Management Act of 1999. Prepared and Submitted by the California Department of Fish and Game, Office of Spill Prevention and Response.

${ }^{15}$ Fairey, R., Dunn, R., Roberts, C., Sigala, M., and J. Oliver. 2002. Introduced Aquatic Species in California Coastal Waters, Final Report. California Department of Fish and Game. San Jose State University Foundation/Moss Landing Marine Laboratories.

${ }^{16}$ A Survey of Non-Indigenous Aquatic Species in the Coastal and Estuarine Waters of California. 2002. Submitted to the California State Legislature as required by the Ballast Water Management Act of 1999. Prepared and Submitted by the California Department of Fish 
and Game, Office of Spill Prevention and

Response.

${ }^{17}$ A Survey of Non-Indigenous Aquatic Species

in the Coastal and Estuarine Waters of

California. 2002. Submitted to the California

State Legislature as required by the Ballast

Water Management Act of 1999. Prepared and

Submitted by the California Department of Fish

and Game, Office of Spill Prevention and

Response.

${ }^{18}$ Minnesota SeaGrant. Glossary of the Great

Lakes.

http://www.seagrant.umn.edu/pubs/ggl/n.html\#N 12. Accessed May 4, 2006.

${ }^{19}$ A Survey of Non-Indigenous Aquatic Species in the Coastal and Estuarine Waters of California. 2002. Submitted to the California

State Legislature as required by the Ballast Water Management Act of 1999. Prepared and Submitted by the California Department of Fish and Game, Office of Spill Prevention and Response.

${ }^{20}$ U.S. Fish and Wildlife Service. Definitions: Region 3 Midwest Internet Site. http://www.fws.gov/midwest/ashland/definitions. html. Accessed May 4, 2006

${ }^{21}$ Reef Research Center. 2004. Introduced species in tropical waters: Current state of knowledge. CRC Reef Research Centre Ltd. ${ }^{22}$ California Department of Fish and Game. 2003. California Aquatic Invasive Species Management Plan. Draft.

${ }^{23}$ Coutts, A.D.M., Moore, K.M., and Hewitt, C.L. Ships' sea-chests: an overlooked transfer mechanism for non-indigenous marine species? Marine Pollution Bulletin 46(11): 1510-1513, 2003.

${ }^{24}$ U.S. Environmental Protection Agency. Terms of Environment: Glossary, Abbreviations and Acronyms.

http://www.epa.gov/OCEPAterms/xyzterms.html Accessed May 4, 2006. 
Appendix B. Examples of Aquatic Invasive Species Transported on Hulls

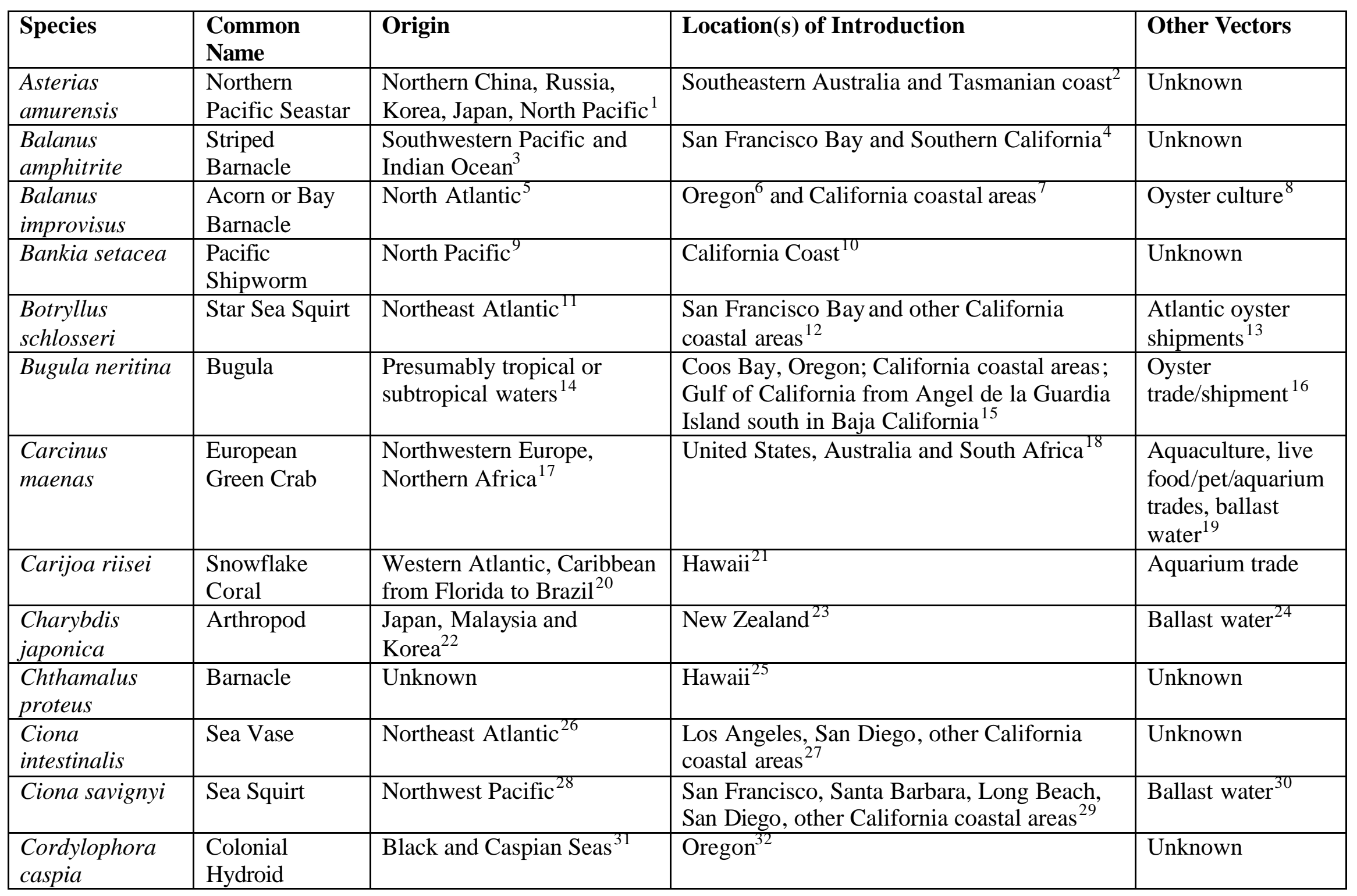

App. B-1 


\begin{tabular}{|c|c|c|c|c|}
\hline Species & $\begin{array}{l}\text { Common } \\
\text { Name }\end{array}$ & Origin & Location(s) of Introduction & Other Vectors \\
\hline $\begin{array}{l}\text { Grandidierella } \\
\text { japonica }\end{array}$ & Amphipod & $\operatorname{Japan}^{36}$ & Oregon $^{37}$ & Unknown \\
\hline $\begin{array}{l}\text { Hemigrapsus } \\
\text { sanguineus }\end{array}$ & $\begin{array}{l}\text { Japanese Shore } \\
\text { Crab }\end{array}$ & Unknown & U.S. Atlantic Coast ${ }^{38}$ & Ballast water \\
\hline $\begin{array}{l}\text { Hydroides } \\
\text { sanctaecrucis }\end{array}$ & $\begin{array}{l}\text { Caribbean } \\
\text { Tubeworm }\end{array}$ & Caribbean $^{39}$ & Australia $^{40}$ & Ballast water $^{41}$ \\
\hline $\begin{array}{l}\text { Monocorophium } \\
\text { acherusicum }\end{array}$ & Amphipod & North Atlantic ${ }^{47}$ & Oregon $^{48}$ & Unknown \\
\hline Mytilopsis sallei & $\begin{array}{l}\text { Black-striped } \\
\text { Mussel }\end{array}$ & $\begin{array}{l}\text { Western Atlantic and } \\
\text { Caribbean from the Gulf of } \\
\text { Mexico to Columbia } 4950\end{array}$ & Australia $^{51}$ & Unknown \\
\hline $\begin{array}{l}\text { Mytilus } \\
\text { galloprovincialis }\end{array}$ & $\begin{array}{l}\text { Mediterranean } \\
\text { Mussel or Blue } \\
\text { Mussel }\end{array}$ & Northeastern Atlantic $^{52}$ & $\begin{array}{l}\text { Hawaii and parts of the United States } \\
\text { including California coastal areas }\end{array}$ & Ballast water $^{55}$ \\
\hline
\end{tabular}




\begin{tabular}{|c|c|c|c|c|}
\hline Species & Common Name & Origin & Location(s) of Introduction & Other vectors \\
\hline Perna perna & Brown Mussel & $\begin{array}{l}\text { Tropical and subtropical } \\
\text { regions of the Atlantic } \\
56\end{array}$ & Gulf of Mexico Coast ${ }^{51}$ & Unknown \\
\hline Perna viridis & $\begin{array}{l}\text { Asian Green } \\
\text { Mussel }\end{array}$ & Pacific Northwest $^{58}$ & Australia $^{59}$ & Ballast water $^{60}$ \\
\hline $\begin{array}{l}\text { Phyllorhiza } \\
\text { punctata }\end{array}$ & Spotted Jellyfish & Australia $^{61}$ & $\begin{array}{l}\text { California, Gulf of Mexico Coast, Hawaii, } \\
\text { Caribbean }^{62}\end{array}$ & Unknown \\
\hline Rapana veinosa & $\begin{array}{l}\text { Veined Rapa } \\
\text { Whelk }\end{array}$ & $\begin{array}{l}\text { Sea of Japan, Yellow and } \\
\text { East China Seas and Gulf of } \\
\text { Bohai. }{ }^{63}\end{array}$ & $\begin{array}{l}\text { U.S. Atlantic Coast }{ }^{64}, \text { Mediterranean, } \\
\text { Black, Aegean and Adriatic Seas }{ }^{65}\end{array}$ & Ballast water $^{66}$ \\
\hline $\begin{array}{l}\text { Sabella } \\
\text { spallanzanii }\end{array}$ & $\begin{array}{l}\text { European Feather } \\
\text { Duster Worm }\end{array}$ & Unknown & Australia $^{67}$ & Unknown \\
\hline $\begin{array}{l}\text { Sphaeroma } \\
\text { quoyanum }\end{array}$ & $\begin{array}{l}\text { Australasian } \\
\text { Isopod }\end{array}$ & Southwest Pacific $^{68}$ & $\begin{array}{l}\text { San Francisco and San Pablo Bays, and } \\
\text { other California coastal areas } 69 \\
\end{array}$ & Unknown \\
\hline $\begin{array}{l}\text { Sphaeroma } \\
\text { walkeri }\end{array}$ & Isopod & $\begin{array}{l}\text { Western and Southwestern } \\
\text { Pacific }^{70}\end{array}$ & San Diego $^{71}$ & Unknown \\
\hline $\begin{array}{l}\text { Symplegma } \\
\text { reptans }\end{array}$ & Ascidian & Northwest Pacific $^{75}$ & $\begin{array}{l}\text { San Diego, Long Beach, and other } \\
\text { California coastal areas }\end{array}$ & Ballast water $^{77}$ \\
\hline Teredo navalis & $\begin{array}{l}\text { Atlantic } \\
\text { Shipworm } \\
\end{array}$ & Pacific Northwest $^{18}$ & San Francisco Bay ${ }^{79}$ & Unknown \\
\hline $\begin{array}{l}\text { Undaria } \\
\text { pinnatifida }\end{array}$ & Japanese Kelp & Northwest Pacific $^{80}$ & $\begin{array}{l}\text { San Diego, Baja California, Argentina, } \\
\text { Europe, Australia, New Zealand, Russia, } \\
\text { Monterey Harbor }\end{array}$ & Ballast water $^{83}$ \\
\hline $\begin{array}{l}\text { Zoobotryon } \\
\text { verticillatum }\end{array}$ & $\begin{array}{l}\text { Spaghetti } \\
\text { Bryozoan }\end{array}$ & Unknown & $\begin{array}{l}\text { San Diego, San Francisco Bay, and other } \\
\text { California coastal areas } 84\end{array}$ & Unknown \\
\hline
\end{tabular}




\section{References}

${ }^{1}$ Elkhorn Slough National Estuarine Research Reserve, "Least Wanted Aquatic Invaders," http://www.elkhornslough.org/research/aquaticinvade rs/aquatic20.htm Accessed: September 9, 2005. ${ }^{2}$ Elkhorn Slough National Estuarine Research Reserve, "Least Wanted Aquatic Invaders," http://www.elkhornslough.org/research/aquaticinvade rs/aquatic20.htm Accessed: September 9, 2005.

${ }^{3}$ Elkhorn Slough National Estuarine Research Reserve, "Least Wanted Aquatic Invaders," http://www.elkhornslough.org/research/aquaticinvade rs/aquatic6.htmAccessed: September 7, 2005.

${ }^{4}$ Elkhorn Slough National Estuarine Research Reserve, "Least Wanted Aquatic Invaders," http://www.elkhornslough.org/research/aquaticinvade rs/aquatic6.htmAccessed: September 7, 2005.

${ }^{5}$ Draheim, R.W., J.W. Chapman, J. Cordell, and M. Sytsma. 2003. Interim Report. Lower Columbia River Aquatic Nonindigenous Species Survey 2001 2003.

${ }^{6}$ Draheim, R.W., J.W. Chapman, J. Cordell, and M. Sytsma. 2003. Interim Report. Lower Columbia River Aquatic Nonindigenous Species Survey 2001 2003.

${ }^{7}$ Wasson, K., C. Zabin, L. Bedinger, M. Diaz, J. Pearse. 2001. Biological invasions of estuaries without international shipping: the importance of intraregional transport. Biological Conservation 102: 143-153.

${ }^{8}$ Wasson, K., C. Zabin, L. Bedinger, M. Diaz, J. Pearse. 2001. Biological invasions of estuaries without international shipping: the importance of intraregional transport. Biological Conservation 102: 143-153.

${ }^{9}$ Cohen, Andrew N. 2004. Invasions in the Sea. Park Science 22 (Fall): 37-41.

${ }^{10}$ Cohen, Andrew N. 2004. Invasions in the Sea. Park Science 22 (Fall): 37-41.

${ }^{11}$ Cohen, A., L. Harris, B. Bingham, J. Carlton, J. Chapman, C. Lamb ert, G. Lambert, J. Ljubenkov, S. Murray, L. Rao, K. Reardon and E. Schwindt. 2002. A Rapid Assessment Survey of Exotic Species in Sheltered Coastal Waters. For the California Department of Fish and Game, Sacramento, CA, the State Water Resources Control Board, Sacramento, $\mathrm{CA}$ and the National Fish and Wildlife Foundation, San Francisco, CA.

${ }^{12}$ Lambert, C. and G. Lambert. 1998. Nonindigenous ascidians in southern California harbors and marinas. Mar Biology 130: 685.

${ }^{13}$ Cohen, A., L. Harris, B. Bingham, J. Carton, J. Chapman, C. Lambert, G. Lambert, J. Ljubenkov, S. Murray, L. Rao, K. Reardon and E. Schwindt. 2002.
A Rapid Assessment Survey of Exotic Species in Sheltered Coastal Waters. For the California Department of Fish and Game, Sacramento, CA, the State Water Resources Control Board, Sacramento, CA and the National Fish and Wildlife Foundation, San Francisco, CA.

${ }^{14}$ Cohen, Andrew N. 2005 Guide to the Exotic Species of San Francisco Bay. San Francisco Estuary Institute, Oakland, CA, Accessed at: http://www.exoticsguide.org.

${ }^{15}$ Ibid.

${ }^{16}$ Ibid.

${ }^{17}$ Global Invasive Species Database, "Carcinus Maenas,"

http://www.issg.org/database/species/ecology.asp?si= 114\&fr=1\&sts=sss Accessed: September 9, 2005.

18 Global Invasive Species Database, "Carcinus Maenas,"

http://www.issg.org/database/species/ecology.asp?si= 114\&fr=1\&sts=sss Accessed: September 9, 2005.

19 Global Invasive Species Database, "Carcinus

Maenas,"

http://www.issg.org/database/species/ecology.asp?si= $114 \& \mathrm{fr}=1 \&$ sts $=$ sss Accessed: September 9, 2005.

${ }^{20}$ Global Invasive Species Database, "Carijoa riisei," http://www.issg.org/database/species/ecology.asp?si= 694\&fr=1\&sts=sss Accessed: September 9, 2005.

${ }^{21}$ Global Invasive Species Database, "Carijoa riisei," http://www.issg.org/database/species/ecology.asp?si= 694\&fr=1\&sts=sss Accessed: September 9, 2005.

${ }^{22}$ New Zealand Ministry of Fisheries, "Marine Biosecurity Fact Sheet," http://www.fish.govt.nz/sustainability/biosecurity/pes ts/charybdis_fact_sheet.pdf Accessed: August 31, 2005.

${ }^{23}$ New Zealand Ministry of Fisheries, "Marine Biosecurity Fact Sheet,"

http://www.fish.govt.nz/sustainability/biosecurity/pes ts/charybdis_fact_sheet.pdf Accessed: August 31, 2005.

${ }^{24}$ New Zealand Ministry of Fisheries, "Marine Biosecurity Fact Sheet,"

http://www.fish.govt.nz/sustainability/biosecurity/pes ts/charybdis_fact_sheet.pdf Accessed: August 31, 2005.

${ }^{25}$ Apte, S., B.S. Holland, L.S. Godwin, and J.P.S. Gardner. 2000. Jumping ship: a steeping stone event mediating transfer of a non-indigenous species via a potentially unsuitable environment. Biological Invasions 2: 75-79.

${ }^{26}$ Cohen, A., L. Harris, B. Bingham, J. Carlton, J. Chapman, C. Lambert, G. Lambert, J. Ljubenkov, S. Murray, L. Rao, K. Reardon and E. Schwindt. 2002. A Rapid Assessment Survey of Exotic Species in Sheltered Coastal Waters. For the California 
Department of Fish and Game, Sacramento, CA, the State Water Resources Control Board, Sacramento, $\mathrm{CA}$ and the National Fish and Wildlife Foundation, San Francisco, CA.

${ }^{27}$ Lambert, C. and G. Lambert. 1998. Nonindigenous ascidians in southern California harbors and marinas. Mar Biology 130: 685.

${ }^{28}$ Cohen, A., L. Harris, B. Bingham, J. Carlton, J. Chapman, C. Lambert, G. Lambert, J. Ljubenkov, S. Murray, L. Rao, K. Reardon and E. Schwindt. 2002. A Rapid Assessment Survey of Exotic Species in Sheltered Coastal Waters. For the California Department of Fish and Game, Sacramento, CA, the State Water Resources Control Board, Sacramento, $\mathrm{CA}$ and the National Fish and Wildlife Foundation, San Francisco, CA.

${ }^{29}$ Lambert, C. and G. Lambert. 1998. Nonindigenous ascidians in southern California harbors and marinas. Mar Biology 130: 685.

${ }^{30}$ Cohen, A., L. Harris, B. Bingham, J. Carlton, J. Chapman, C. Lambert, G. Lambert, J. Ljubenkov, S. Murray, L. Rao, K. Reardon and E. Schwindt. 2002. A Rapid Assessment Survey of Exotic Species in Sheltered Coastal Waters. For the California Department of Fish and Game, Sacramento, CA, the State Water Resources Control Board, Sacramento, $\mathrm{CA}$ and the National Fish and Wildlife Foundation, San Francisco, CA.

${ }^{31}$ Carlton, J.T. 1979. History, Biogeography, and Ecology of the Introduced Marine and Estuarine Invertebrates of the Pacific Coast of North America. $\mathrm{PhD}$ thesis, University of California, Davis. p.230.

${ }^{32}$ Carlton, J.T. 1979. History, Biogeography, and Ecology of the Introduced Marine and Estuarine Invertebrates of the Pacific Coast of North America. $\mathrm{PhD}$ thesis, University of California, Davis. p.230.

${ }^{33}$ Global Invasive Species Database, "Dreissena polymorpha,"

http://www.issg.org/database/species/ecology.asp?si= 50\&fr=1\&sts=sss Accessed: September 9, 2005.

${ }^{34}$ Global Invasive Species Database, "Dreissena polymorpha,"

http://www.issg.org/database/species/ecology.asp?si= 50\&fr $=1 \&$ sts=sss Accessed: September 9, 2005.

${ }^{35}$ Global Invasive Species Database, "Dreissena polymorpha,"

http://www.issg.org/database/species/ecology.asp?si= $50 \& \mathrm{fr}=1 \&$ sts=sss Accessed: September 9, 2005.

${ }^{36}$ Draheim, R.W., J.W. Chapman, J. Cordell, and M. Sytsma. 2003. Interim Report. Lower Columbia River Aquatic Nonindigenous Species Survey 2001 2003.

${ }^{37}$ Draheim, R.W., J.W. Chapman, J. Cordell, and M. Sytsma. 2003. Interim Report. Lower Columbia
River Aquatic Nonindigenous Species Survey 2001 2003.

${ }^{38}$ Fuller, P. 2001. Nonindigenous aquatic species in the United States. Workshop Proceedings: Preventing the Introduction and Spread of Aquatic Invasive Species in North America, March 28-30. Publication prepared by the Secretariat of the Commission for Environmental Cooperation. Jamie Reaser (ed.). 86pp

${ }^{39}$ CSIRO Marine Research, "Marine Pest Information Sheet: Hydroides sanctaecrucis," http://www.marine.csiro.au/crimp/Reports/Infosht15_ Hydroides.pdf Accessed: September 8, 2005.

${ }^{40}$ CRC Reef Research Centre. 2004. Introduced Species in Tropical Waters: Current State of Knowledge. Australia: CRC Reef Research Centre Ltd.

${ }^{41}$ CRC Reef Research Centre. 2004. Introduced Species in Tropical Waters: Current State of Knowledge. Australia: CRC Reef Research Centre Ltd.

${ }^{42}$ Percy, J.A. 2003. Alien invasions: Introduced species in the Bay of Fundy. Bay of Fundy Ecosystem Partnership. SeaPen Communications, Granville Ferry. Nova Scotia. Supported by: The Environmental Conservation Branch Environment Canada - Atlantic Region Dartmouth, Nova Scotia and Department of Fisheries and Oceans ScotiaFundy Region.

http://www.bofep.org/alien_species.htmAccessed September 1, 2005

${ }^{43}$ Percy, J.A. 2003. Alien invasions: Introduced species in the Bay of Fundy. Bay of Fundy Ecosystem Partnership. SeaPen Communications, Granville Ferry. Nova Scotia. Supported by: The Environmental Conservation Branch Environment Canada - Atlantic Region Dartmouth, Nova Scotia and Department of Fisheries and Oceans ScotiaFundy Region.

http://www.bofep.org/alien_species.htm Accessed: September 1, 2005

${ }^{44}$ Cohen, A., L. Harris, B. Bingham, J. Carlton, J. Chapman, C. Lambert, G. Lambert, J. Ljubenkov, S. Murray, L. Rao, K. Reardon and E. Schwindt. 2002. A Rapid Assessment Survey of Exotic Species in Sheltered Coastal Waters. For the California Department of Fish and Game, Sacramento, CA, the State Water Resources Control Board, Sacramento, $\mathrm{CA}$ and the National Fish and Wildlife Foundation, San Francisco, CA.

${ }^{45}$ Lambert, C. and G. Lambert. 1998. Nonindigenous ascidians in southern California harbors and marinas. Mar Biology 130: 685.

${ }^{46}$ Cohen, A., L. Harris, B. Bingham, J. Carlton, J. Chapman, C. Lambert, G. La mbert, J. Ljubenkov, S. Murray, L. Rao, K. Reardon and E. Schwindt. 2002. 
A Rapid Assessment Survey of Exotic Species in Sheltered Coastal Waters. For the California Department of Fish and Game, Sacramento, CA, the State Water Resources Control Board, Sacramento, CA and the National Fish and Wildlife Foundation, San Francisco, CA.

${ }^{47}$ Draheim, R.W., J.W. Chapman, J. Cordell, and M. Sytsma. 2003. Interim Report. Lower Columbia River Aquatic Nonindigenous Species Survey 2001 2003.

${ }^{48}$ Draheim, R.W., J.W. Chapman, J. Cordell, and M. Sytsma. 2003. Interim Report. Lower Columbia River Aquatic Nonindigenous Species Survey 2001 2003.

${ }^{49}$ NSW Department of Primary Industries/Fisheries, "Black-striped Mussel-Mytilopsis sallei,"

http://www.fisheries.nsw.gov.au/threatened_species/ general/content/fn_black-striped_mussel.htm Accessed: September 9, 2005.

${ }^{50}$ Cooperative Research Centre Reef Research Centre, "Underwater Hitchhikers on the Bottom of Boats,"

http://www.reef.crc.org.au/publications/explore/feat5 3.html Accessed: September 9, 2005.

${ }^{51}$ CRC Reef Research Centre. 2004. Introduced Species in Tropical Waters: Current State of Knowledge. Australia: CRC Reef Research Centre Ltd.

${ }^{52}$ Cohen, A., L. Harris, B. Bingham, J. Carlton, J. Chapman, C. Lambert, G. Lambert, J. Ljubenkov, S. Murray, L. Rao, K. Reardon and E. Schwindt. 2002. A Rapid Assessment Survey of Exotic Species in Sheltered Coastal Waters. For the California Department of Fish and Game, Sacramento, CA, the State Water Resources Control Board, Sacramento, CA and the National Fish and Wildlife Foundation, San Francisco, CA.

${ }^{53}$ Global Invasive Species Database, "Mytilus galloprovincialis," http://www.issg.org/database/species/ecology.asp?si= 102\&fr $=1 \&$ sts Accessed: September 12, 2005.

${ }^{54}$ Wasson, K., C. Zabin, L. Bedinger, M. Diaz, J. Pearse. 2001. Biological invasions of estuaries without international shipping: the importance of intraregional transport. Biological Conservation 102: 143-153.

${ }^{55}$ Cohen, A., L. Harris, B. Bingham, J. Carlton, J. Chapman, C. Lambert, G. Lambert, J. Ljubenkov, S. Murray, L. Rao, K. Reardon and E. Schwindt. 2002. A Rapid Assessment Survey of Exotic Species in Sheltered Coastal Waters. For the California Department of Fish and Game, Sacramento, CA, the State Water Resources Control Board, Sacramento, $\mathrm{CA}$ and the National Fish and Wildlife Foundation, San Francisco, CA.
${ }^{56}$ Mobile Bay National Estuary Program. http://www.mobilebaynep.com/AMRAT/AMRAT\%2 OSpecies.htm Accessed September 9, 2005.

${ }^{57}$ Fuller, P. 2001. Nonindigenous aquatic species in the United States. Workshop Proceedings: Preventing the Introduction and Spread of Aquatic Invasive Species in North America, March 28-30. Publication prepared by the Secretariat of the Commission for Environmental Cooperation. Jamie Reaser (ed.). 86pp ${ }^{58}$ Global Invasive Species Database, "Perna viridis," http://www.issg.org/database/species/ecology.asp?si= 731\&fr $=1 \&$ sts $=$ sss Accessed: September 12, 2005.

${ }^{59}$ CRC Reef Research Centre. 2004. Introduced Species in Tropical Waters: Current State of Knowledge. Australia: CRC Reef Research Centre Ltd.

${ }^{60}$ Global Invasive Species Database, "Perna viridis," http://www.issg.org/database/species/ecology.asp?si= 731\&fr=1\&sts=sss Accessed: September 12, 2005.

${ }^{61}$ Elkhorn Slough National Estuarine Research Reserve, "Least Wanted Aquatic Invaders," http://www.elkhornslough.org/research/aquaticinvade rs/aquatic5.htmAccessed: September 8, 2005.

${ }^{62}$ Elkhorn Slough National Estuarine Research Reserve, "Least Wanted Aquatic Invaders," http://www.elkhornslough.org/research/aquaticinvade rs/aquatic5.htmAccessed: September 8, 2005.

${ }^{63}$ Elkhorn Slough National Estuarine Research

Reserve, "Least Wanted Aquatic Invaders," http://www.elkhornslough.org/research/aquaticinvade rs/aquatic13.htm Accessed: September 9, 2005.

${ }^{64}$ Fuller, P. 2001. Nonindigenous aquatic species in the United States. Workshop Proceedings: Preventing the Introduction and Spread of Aquatic Invasive

Species in North America, March 28-30. Publication prepared by the Secretariat of the Commission for Environmental Cooperation. Jamie Reaser (ed.). 86pp ${ }^{65}$ Elkhorn Slough National Estuarine Research Reserve, "Least Wanted Aquatic Invaders," http://www.elkhornslough.org/research/aquaticinvade rs/aquatic13.htm Accessed: September 9, 2005.

${ }^{66}$ Fuller, P. 2001. Nonindigenous aquatic species in the United States. Workshop Proceedings: Preventing the Introduction and Spread of Aquatic Invasive Species in North America, March 28-30. Publication prepared by the Secretariat of the Commission for Environmental Cooperation. Jamie Reaser (ed.). 86pp ${ }^{67}$ Bonny, M. 1995. "Preventing the invasion of marine immigrants", Search 26(3), April 1995.

${ }^{68}$ Cohen, A., L. Harris, B. Bingham, J. Carlton, J. Chapman, C. Lambert, G. Lambert, J. Ljubenkov, S. Murray, L. Rao, K. Reardon and E. Schwindt. 2002. A Rapid Assessment Survey of Exotic Species in Sheltered Coastal Waters. For the California Department of Fish and Game, Sacramento, CA, the 
State Water Resources Control Board, Sacramento, $\mathrm{CA}$ and the National Fish and Wildlife Foundation, San Francisco, CA.

${ }^{69}$ Wasson, K., C. Zabin, L. Bedinger, M. Diaz, J. Pearse. 2001. Biological invasions of estuaries without international shipping: the importance of intraregional transport. Biological Conservation 102: 143-153.

${ }^{70}$ Minchin, D., and S. Gollasch. 2003. Fouling and Ships' Hulls: How Changing Circumstances and Spawning Events may Result in the Spread of Exotic Species. Biofouling, Vol. 19 (Supplement), pp. 111122.

${ }^{71}$ Minchin, D., and S. Gollasch. 2003. Fouling and Ships' Hulls: How Changing Circumstances and Spawning Events may Result in the Spread of Exotic Species. Biofouling, Vol. 19 (Supplement), pp. 111122.

${ }^{72}$ Cohen, A., L. Harris, B. Bingham, J. Carlton, J. Chapman, C. Lambert, G. Lambert, J. Ljubenkov, S. Murray, L. Rao, K. Reardon and E. Schwindt. 2002. A Rapid Assessment Survey of Exotic Species in Sheltered Coastal Waters. For the California Department of Fish and Game, Sacramento, CA, the State Water Resources Control Board, Sacramento, $\mathrm{CA}$ and the National Fish and Wildlife Foundation, San Francisco, CA.

${ }^{73}$ Lambert, C. and G. Lambert. 1998. Nonindigenous ascidians in southern California harbors and marinas. Mar Biology 130: 685.

${ }^{74}$ Cohen, A., L. Harris, B. Bingham, J. Carlton, J. Chapman, C. Lambert, G. Lambert, J. Ljubenkov, S. Murray, L. Rao, K. Reardon and E. Schwindt. 2002. A Rapid Assessment Survey of Exotic Species in Sheltered Coastal Waters. For the California Department of Fish and Game, Sacramento, CA, the State Water Resources Control Board, Sacramento, $\mathrm{CA}$ and the National Fish and Wildlife Foundation, San Francisco, CA.

${ }^{75}$ Cohen, A., L. Harris, B. Bingham, J. Carlton, J. Chapman, C. Lambert, G. Lambert, J. Ljubenkov, S. Murray, L. Rao, K. Reardon and E. Schwindt. 2002. A Rapid Assessment Survey of Exotic Species in Sheltered Coastal Waters. For the California Department of Fish and Game, Sacramento, CA, the State Water Resources Control Board, Sacramento, $\mathrm{CA}$ and the National Fish and Wildlife Foundation, San Francisco, CA.

${ }^{76}$ Lambert, C. and G. Lambert. 1998. Non-

indigenous ascidians in southern California harbors and marinas. Mar Biology 130: 685.

${ }^{77}$ Cohen, A., L. Harris, B. Bingham, J. Carlton, J. Chapman, C. Lambert, G. Lambert, J. Ljubenkov, S. Murray, L. Rao, K. Reardon and E. Schwindt. 2002. A Rapid Assessment Survey of Exotic Species in
Sheltered Coastal Waters. For the California Department of Fish and Game, Sacramento, CA, the State Water Resources Control Board, Sacramento, $\mathrm{CA}$ and the National Fish and Wildlife Foundation, San Francisco, CA.

${ }^{78}$ Gallager S.M., Barlow R.B. Jr., Mann R. 1981. Non-invasive, long-term recording of shipworm boring activity. Biological Bulletin, Marine Biological Laboratory, Woods Hole, 161, pp. 312. ${ }^{79}$ Hill, C.L. and C.A. Kofoid.(eds). 1927. Marine Borers and Their Relation to Marine Construction on the Pacific Coast. Being the Final Report of the San Francisco Bay Marine Piling Committee. Prepared Under the Direction of the San Francisco Bay Marine Piling Committee, Cooperating with the National Research Council and the American WoodPreservers' Association.

${ }^{80}$ Cohen, A., L. Harris, B. Bingham J. Carlton, J. Chapman, C. Lambert, G. Lambert, J. Ljubenkov, S. Murray, L. Rao, K. Reardon and E. Schwindt. 2002. A Rapid Assessment Survey of Exotic Species in Sheltered Coastal Waters. For the California Department of Fish and Game, Sacramento, CA, the State Water Resources Control Board, Sacramento, $\mathrm{CA}$ and the National Fish and Wildlife Foundation, San Francisco, CA.

${ }^{81}$ Elkhorn Slough National Estuarine Research Reserve, "Least Unwanted Aquatic Invaders," http://www.elkhornslough.org/research/aquaticin vade rs/aquatic2.htmAccessed: September 9, 2005.

${ }^{82}$ Ribera Siguan, M. A. 2003. Pathways of Biological Invasions of Marine Plants. In: Invasive Species Vectors and Management Strategies. (G.M. Ruiz and J.T. Carlton eds) Island Press: Washington DC.

${ }^{83}$ Cohen, A., L. Harris, B. Bingham, J. Carlton, J. Chapman, C. Lambert, G. Lambert, J. Ljubenkov, S. Murray, L. Rao, K. Reardon and E. Schwindt. 2002. A Rapid Assessment Survey of Exotic Species in Sheltered Coastal Waters. For the California Department of Fish and Game, Sacramento, CA, the State Water Resources Control Board, Sacramento, $\mathrm{CA}$ and the National Fish and Wildlife Foundation, San Francisco, CA.

${ }^{84}$ Elkhorn Slough National Estuarine Research Reserve, "Least Wanted Aquatic Invaders," http://www.elkhornslough.org/research/aquaticinvade rs/aquatic21.htm Accessed: September 8, 2005. 


\section{Appendix C. English/Spanish and Spanish/English Dictionary of Technical Terms ${ }^{1}$}

\section{English/Spanish:}

Anchor - Ancla

Antifouling paints - Pinturas

antiincrustantes

Aquaculture - Acuicultura

Aquatic Invasive Species - Especies

invasoras acuáticas

Aquatic Invasive Species PreventionPrevención de las especies invasoras acuáticas

Aquatic Organisms - Organismos acuáticos

Ballast Water - Agua de lastre

Bilge Water - Agua de sentina

Boat Drag - Fricción del bote

Boat Hull - Casco del bote

Boat Maintenance - Mantenimiento del casco

Boat Owners - Dueños de los botes

Boating/Shipping/Vessels -

Embarcaciones

Clams - Almejas

Coast / Shoreline - La costa

Coastal Structures - Estructuras costeras

\footnotetext{
${ }^{1}$ Prepared by Cesar J. Alvarez
}

Commercial Fishing - Pesca comercial

Cooling Intakes - Tomas de refrigeración

Copper - Cobre

Cultured Oysters - Ostras cultivadas

Ecological Damage - Daño ecológico

Economic Damage - Daño económico

Eradication - Eradicación

Fishermen - Pescadores

Fishing Nets - Redes de pesca

Harbor - Dársena / Puerto ${ }^{2}$

Hull Cleaning - Limpieza del casco

Hull Fouling - Adherencias en los cascos de las embarcaciones

In-water Hull Cleaning - Limpieza del casco dentro del agua

Livewell/Bait Tank - Tanque de carnada

Marina - Marina

Marina Managers - Gerentes de las marinas

Motorboat - Lancha

Mussels-Mejillones

Native Region / Habitat - Región nativa / hábitat

Native Organisms - Organismos nativos

\footnotetext{
${ }^{2}$ Puerto tends to be used by the Mexican general public to mean both harbor and port
} 
Nonindigenous Species - Especies no nativas / especies exóticas

Nontoxic - No tóxico

Pier / Dock - Muelle

Port - Puerto

Propeller - Hélice

Recreational Boat - Bote recreativo / bote de placer

Sailboat - Velero

Shellfish - Moluscos

Seafood - Alimentos del mar

Seaweed - Algas marinas

Ship - Barco

Sportfishing - Pesca deportiva / pesca recreativa

Taxonomy - Taxonomía

Technical Damage - Daño técnico

Transport by boat hulls - Transporte por los cascos de las embarcaciones

Yacht - Yate

\section{Spanish/English:}

Acuicultura - Aquaculture

Adherencias en los cascos de las embarcaciones - Hull Fouling

Agua de lastre - Ballast Water

Agua de sentina - Bilge Water
Algas marinas - Seaweed

Alimentos del mar - Seafood

Almejas - Clams

Ancla - Anchor

Barco - Ship

Bote recreativo / bote de placerRecreational Boat

Casco del bote - Boat Hull

Cobre-Copper

Costa - Coast / Shoreline

Daño ecológico - Ecological Damage

Daño económico - Economic Damage

Daño técnico - Technical Damage

Dársena - Harbor

Dueños de los botes - Boat Owners

Embarcaciones -

Boating/Shipping/Vessels

Eradicación - Eradication

Especies invasoras acuáticas - Aquatic Invasive Species

Especies no nativas / especies exóticas Nonindigenous Species

Estructuras costeras - Coastal Structures

Fricción del bote- Boat Drag 
Gerentes de las marinas - Marina

Managers

Hélice - Propeller

Lancha - Motorboat

Limpieza del casco - Hull Cleaning

Limpieza del casco dentro del agua - Inwater Hull Cleaning

Mantenimiento del casco - Boat

Maintenance

Marina - Marina

Mejillones - Mussels

Moluscos - Shellfish

Muelle - Pier / Dock

No tóxico - Nontoxic

Organismos acuáticos - Aquatic

Organisms

Organismos nativos - Native Organisms

Ostras cultivadas - Cultured Oysters

Pesca comercial - Commercial Fishing

Pesca deportiva / pesca recreativaSportfishing

Pescadores - Fishermen

Pinturas antiincrustantes - Antifouling paints

Prevención de las especies invasoras acuáticas - Aquatic Invasive Species Prevention
Puerto - Port

Redes de pesca - Fishing Nets

Región nativa / hábitat - Native Region / Habitat

Tanque de carnada - Livewell/Bait Tank

Taxonomía - Taxonomy

Tomas de refrigeración - Cooling Intakes

Transporte por los cascos de las embarcaciones - Transport by boat hulls

Velero - Sailboat

Yate - Yacht 
Appendix D. Popular California Boating and Fishing Sites ${ }^{1}$

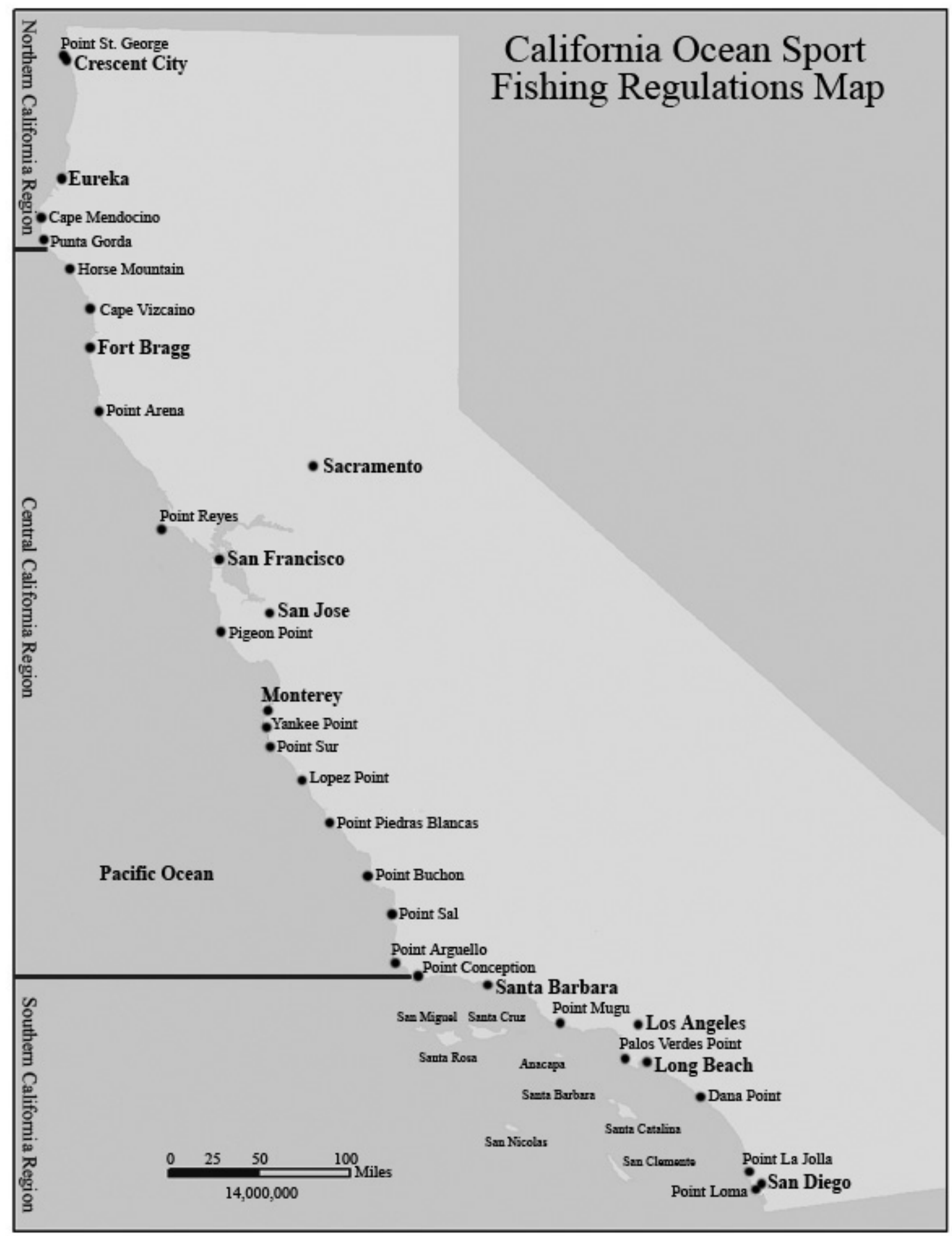

${ }^{1}$ California Department of Fish and Game, Marine Region, "California Ocean Sport Fishing Regulations Map," http://www.dfg.ca.gov/mrd/fishing_map.html Accessed: August 30, 2005. Reprinted by permission. 


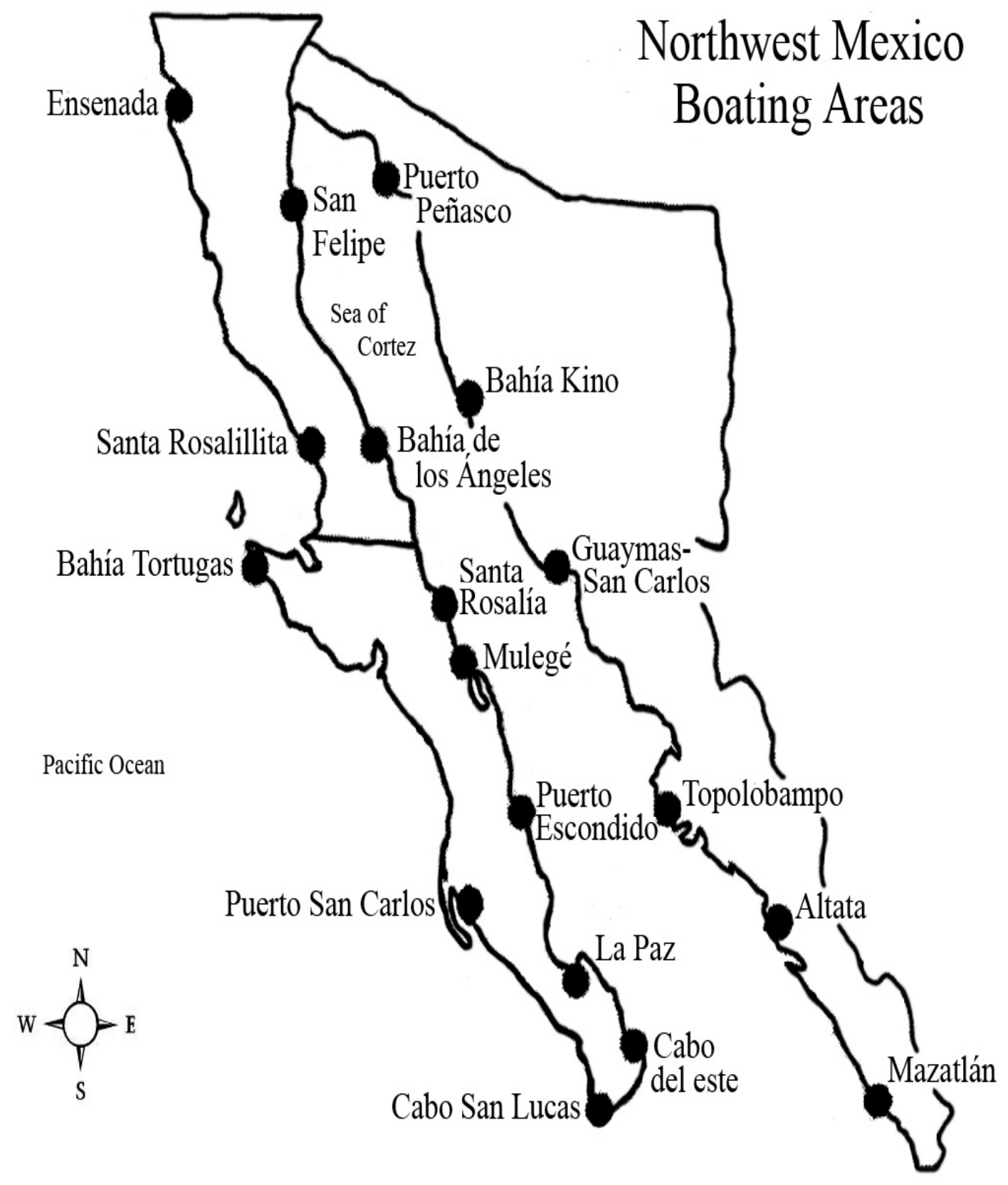

${ }^{1}$ Conlon, Michael. 2002. Northwest Mexico Marina Market Analysis. Prepared for the Packard Foundation, EDAW, i-2. Reprinted by permission. 
Appendix F. Recommendations from May 11, 2005 Workshop, "Managing Hull Transport of Aquatic Invasive Species"

The following recommendations are based on deliberations by 66 participants at the May 11, 2005 workshop, "Managing Hull Transport of Aquatic Invasive Species," which we convened in collaboration with California State Lands Commission. That workshop considered hull-borne invasive species on both ships and boats, so these recommendations include measures for ships and for boats. Please see the Proceedings of the workshop for complete presentations by seven speakers. ${ }^{1}$

Workshop participants represented:

- policy makers;

- boat and ship owners;

- boat and ship maintenance, repair and coating businesses;

- port, harbor, marina and yacht club managers;

- scientists;

- government agencies; and

- environmental organizations

They were divided into three groups, asked to deliberate on five questions and reconvened for plenary discussion. Points of general (but not necessarily unanimous) agreement or discussion are included in this summary.

Question 1. Does ship/boat fouling pose an invasive species risk that needs to be addressed?

The majority believed that fouling poses a risk that should be addressed. One group felt that fouling posed a risk, but the severity of that risk, and where the majority of the risk fell with respect to recreational or commercial vessels, was unclear.
One point was that the commercial industry should not be held entirely responsible for the coastal transport of invasive species. The recreational boating community likely has some level of responsibility, but to what extent is unknown.

Recreational boats may pose less risk for aquatic invasive species (AIS) transport, due to their shorter and less frequent voyages. However, research is required to confirm this hypothesis. The operational dynamic is more important than the total area of a hull surface. It is important to evaluate vessels that remain in place for long periods of time and then travel considerable distances to other regions. Studies in Hawaii have found that such trips may expose a single destination to repeated AIS inoculations.

This topic raised a few points about risk of AIS transfer by commercial vessels. In Hawaii, studies have shown that regularly scheduled vessels are not a problem. In terms of hull fouling, slow moving barges and vessels with irregular routes are of most concern.

Discussions for commercial vessels focused particularly on antifouling paints, as well as sea chests, anchor housings and chains.

Discussions for recreational boaters included topics such as how often a boat is used, types of uses (racing versus leisure), distance traveled, and the lifespan of a particular boat.

Question 2. What needs to be considered in solving the problem of hull transport of invasive species by recreational and commercial vessels?

Goal: Reduce the number of organisms associated with the bottoms of boats and ships. 
$>$ Because it is not possible to predict what the next problematic invader might be, because control is generally much more costly than prevention, and because eradication is not typically successful, consider a vector-based management approach that minimizes introductions via the fouling vector as a whole.

$>$ Consider incorporating a risk-based system that prioritizes high-risk vessels or situations. Factors that may be used to evaluate the risk of a vessel or situation are:

- Vessel behavior (speed, mooring time)

- Vessel type

- Hull husbandry practices

- Season

- Age of antifouling paint

- Vessel voyage route

- Port region/location

$>$ Consider what amount of burden would be carried by the vessel owners, operators, marinas, or companies that would be responsible for invasive species prevention.

$>$ Some species may not be a problem now but could be in the future and some species are more harmful in certain areas than in others.

$>$ Examine existing program models (i.e. Australia, New Zealand, Hawaii) to observe lessons learned and to avoid pitfalls.

$>$ Consider water quality issues and regulations with respect to biocidal coatings.

$>$ Consider funding for AIS prevention.

$>$ Consider transfers within and between states.

$>$ With eradication control, government agencies pay the costs through taxpayer monies, whereas with prevention the boating/commercial shipping community will bear more of the cost.

$>$ Environmental, social and economic values affect public perspectives and responses. These would have a significant influence on decisions

$>$ Representatives of the recreational boating community strongly advocate outreach and education as the primary method of problem solving.

$>$ Representatives of the commercial maritime industry leaned towards some form of hull management guidelines or regulatory framework

$>$ Overall, regulatory programs should be based on the level of willingness of the community to adopt best management practices (BMPs) and on sound evidence that the BMPs are effective and compliance is high

$>$ Management procedures for the commercial maritime industry will most likely be different from those for the recreational boating community

$>$ Consider a management framework based on the hull husbandry practices of ships and boats (see question 3 below)

$>$ Any management measures proposed should incorporate a level of simplicity

$>$ Once hull management strategies (or regulations) are in place, there will be some need for verification or validation that the procedures are effective over time

Question 3. Where, how, and when should vessels be maintained to prevent fouling AIS introductions?

Although there was no consensus on what type of hull maintenance procedures should be adopted, discussions generated several potential practices that could be adopted, and the advantages and disadvantages of each.

$>$ Periodically maintain antifouling coatings, with a preference for biocidefree coatings

$>$ Coating application or cleaning regularity could be certified to verify 
that a vessel has been maintained properly. At this time, however, some nontoxic coatings are initially very costly, and are undergoing testing and further development

$>$ Economic incentives, such as tax credits and fee waivers, could be employed to encourage the use of nontoxic coatings

$>$ Remove fouling organisms regularly from hulls as well as from other areas such as sea chests, anchors, etc. Ideally for AIS prevention, this would be done out of the water. However, this process is expensive and time consuming. Inwater cleaning is more common and less costly, but current methods generally result in the release of fouling organisms into harbors or ports.

$>$ A code for "Best Management Practices" could be adopted for fouling maintenance

$>$ Vessels could be cleaned upon departure from California and inspected upon return

$>$ Maintenance will depend on the willingness of the vessel operators to incur the costs

$>$ Use a stepwise approach:

- 1st level: Educating vessel owners

- 2nd level: Awareness/warning

-3rd level: Regulation/hammer

Commercial Maritime Industry Practices

- Generally dry dock for hull cleaning on a set schedule

- If fuel efficiency is poor, then hull cleaning is performed

\footnotetext{
$>$ Recreational Boating Community Practices

- Generally clean hulls before each summer season depending on geographic location

- Competitive racing boats are cleaned more often
}

- In northern California, boaters would feel imposition if hull cleaning were required more than once every two years

- In southern California, recreational boaters clean hulls about once every month

$>$ Silicone-based paints

- Some are the same price per square foot as other common antifouling paints

- Largest cost is to strip previous paint coatings before application

- Provides a smooth surface that increases fuel efficiency

- Simply maintained by wiping the hull down between dry docking

- Requires dry docking approximately once every five years

- Convincing the industry that it is a worthwhile investment is difficult

$>$ Silicone-based paint issues relevant to the commercial maritime industry

- May be good for Matson type commercial vessels which are typically container carriers with +20 knots operating speed

- May not be so good for Chevron type commercial vessels which are typically tankers that seldom reach above 18 knots operating speed and stay longer in ports

- In New Zealand, high rates of survival have been found in sea chests and anchor housing

- Silicone-based paints have been found to be highly effective in sea chest areas

$>$ Silicone-based paint issues relevant to the recreational boating community

- Little economic incentive to strip and repaint hulls of recreational boats

- Boat owners only tend to keep boats six to seven years

- Possibly more valuable to high-speed, racing boaters

Vessels' hulls are microcosms with many living organisms that have been found to be highly durable. Hull-husbandry practices should carefully consider preventive 
measures. Suggestions included using slowrelease, biocide blocks in sea chests or some other practice such as regular freshwater flushing.

Mechanical in-water scrubbing services for recreational boats

- Most opposed mechanical service and favored divers

- Compromise might be:

- mechanical cleaning every six months

- diver cleaning every six weeks

$>$ Possible management solution could be a certificate program

- Require certificate of hull cleaning

- Show how often hull has been cleaned

- Document length of time vessel is in marina or port

\section{Question 4. What information gaps need to be closed?}

$>$ The relative risk posed by vessels based on vessel type, vessel behavior, and port conditions (e.g. geographic location, water temperature, salinity, nutrients, seasonal conditions, fouling species that are present)

$>$ Current maintenance practices of vessels. This could be advanced through a survey that asks vessel operators or owners:

- How long was the vessel at the last port of call?

- When was paint last applied to the vessel's hull?

- When was the vessel last in dry dock for hull cleaning?

$>$ Extent of biofouling as it is affected by factors such as:

- Vessel type

- Hull maintenance practices

- Vessel activity

$>$ Management practices of high-risk boats and vessels need to be determined
Develop better communications among members of inter-agency working groups

$>$ Vessel movement patterns

$>$ Economic and ecological impacts of AIS

$>$ Survey vessel owners and harbor masters:

- Identify what they are doing via existing practices

- Learn from existing models

\section{Question 5. What are the outreach and educational needs for AIS prevention in California for recreational boats and commercial ships?}

$>$ In general, outreach and education were deemed to be very important, and were particularly advocated for and by representatives of recreational boating. Therefore, potential outreach means that were discussed applied largely to the recreational community. Programs such as BoatUS, Clean Marina, U.S. Coast Guard Sea Partners, and Sea Grant may be good avenues to develop outreach to the recreational boating community: - Information on early detection - Lessons learned from New Zealand, Australia, Minnesota, and Hawaii

- Monitoring for AIS: Public can be trained to help

- Report findings: need website and contact information to answer questions

$>$ Develop prevention materials: Once AIS are established they are difficult to eradicate. Focus on prevention.

$>$ Partner with industry for outreach: strengthen collaborations

$>$ Work with boating associations to extend information to boaters and industry

$>$ Boat and marine supply stores are best way to extend information to California boaters 
Need to see relationship between efforts to protect water quality from impacts of copper antifoulants and efforts to control invasive species in hull fouling

$>$ Increased communication between scientists and commercial/recreational stakeholders regarding magnitude of the invasive species problem

$>$ Suggestions that could be applied to the commercial industry include:

- Advertisements/articles in industry publications (magazines)

- Distribution of posters and brochures

to commercial community

- Internet/email distribution of information

- Communication between agencies involved with maritime issues should be facilitated. In Hawaii, this is the major means by which many high-risk vessel movements are tracked (i.e., fishing vessels, barges, etc.)

\section{Workshop Closing Discussion Key Points}

The following is a summary of the points of consensus among the workshop participants on management considerations for controlling the hull transport of invasive species:

$>$ Resources should be focused on prevention and on high risk species.

$>$ A risk-based approach should be used to develop the best strategies for management based on:

- vessel behaviors

- vessel types

- hull husbandry

- seasonal components

- age of paint

- vessel origins and destinations

- different trade groups

$>$ A vector approach should be used for managing prevention and control of invasive species on hulls, anchors, ballast, sea chests, etc.

$>$ Use the species-specific approach for education/case studies.

Solutions will need a cost/benefit analysis.

$>$ It will also be important to consider who should be responsible for the costs of prevention.

$>$ The following actions should be conducted on a continuing basis:

- inter-agency communication for management;

- sharing of research data;

- production of educational handouts and public service announcements for the radio and television.

$>$ It is also important to continue the research, development and evaluation of technologies for fouling prevention and aquatic invasive species control, for example environmentally sound fouling release coatings. Research and development should:

- consider consumers' (boaters') full costs to use potential products;

- beware of claims made for new and unproven technologies;

- recognize the need for independent testing of products and verifiable testing protocols;

- determine what maintenance measures are most effective to control hull-borne invasive species.

\section{Reference}

${ }^{1}$ Gonzalez, J. and L. Johnson, eds. 2005. Managing Hull Transport of Aquatic Invasive Species. Proceedings of May 11, 2005 Workshop in San Francisco, California. California Sea Grant College Program Report T-059. 